UNIVERSIDADE DE SÃO PAULO

INSTITUTO DE PSICOLOGIA

MARIANA INÉS GARBARINO

Crenças sobre a origem dos bebês em crianças de 4 a 9 anos: uma abordagem a partir da psicogênese piagetiana e da psicanálise freudiana

(Versão Corrigida)

SÃO PAULO

2012 
UNIVERSIDADE DE SÃO PAULO

INSTITUTO DE PSICOLOGIA

\section{CRENÇAS SOBRE A ORIGEM DOS BEBÊS EM CRIANÇAS DE 4 A 9 ANOS: UMA ABORDAGEM A PARTIR DA PSICOGÊNESE PIAGETIANA E DA PSICANÁLISE FREUDIANA}

(Versão Corrigida)

Mariana Inés Garbarino

Dissertação apresentada ao Instituto de Psicologia da Universidade de São Paulo para obtenção do título de Mestre em Psicologia.

Área de concentração: Psicologia Escolar e do Desenvolvimento Humano.

Orientadora: Prof ${ }^{\mathrm{a}}$. Associada Maria Thereza Costa Coelho de Souza

São Paulo 
AUTORIZO A REPRODUÇÃO E DIVULGAÇÃO TOTAL OU PARCIAL DESTE TRABALHO, POR QUALQUER MEIO CONVENCIONAL OU ELETRÔNICO, PARA FINS DE ESTUDO E PESQUISA, DESDE QUE CITADA A FONTE.

Catalogação na publicação Biblioteca Dante Moreira Leite Instituto de Psicologia da Universidade de São Paulo

Garbarino, Mariana Inés.

Crenças sobre a origem dos bebês em crianças de 4 a 9 anos: uma abordagem a partir da psicogênese piagetiana e da psicanálise freudiana / Mariana Inés Garbarino; orientadora Maria Thereza Costa Coelho de Souza. -- São Paulo, 2012.

$194 \mathrm{f}$.

Dissertação (Mestrado - Programa de Pós-Graduação em Psicologia. Área de Concentração: Psicologia Escolar e do Desenvolvimento Humano) - Instituto de Psicologia da Universidade de São Paulo.

1. Crenças (não-religiosas) 2. Desenvolvimento cognitivo 3. Desenvolvimento psicossexual 4. Psicogênese 5. Piaget, Jean, 18961980 6. Freud, Sigmund, 1856-1939 7. Construção de conhecimento I. Título. 
Nome: Garbarino, Mariana Inés

Título: Crenças sobre a origem dos bebês em crianças de 4 a 9 anos: uma abordagem a partir da psicogênese piagetiana e da psicanálise freudiana.

Dissertação apresentada ao Instituto de Psicologia da Universidade de São Paulo para obtenção do título de Mestre em Psicologia

Aprovado em:

Banca Examinadora

Prof. Dr.

Instituição: Assinatura:

Prof. Dr.

Instituição: Assinatura:

Prof. Dr.

Instituição: Assinatura: 


\section{AGRADECIMENTOS}

À Profa. Associada Maria Thereza Costa Coelho de Souza, por sua grande competência como orientadora, pesquisadora e professora. Obrigada pela dedicação, a inteligência e o respeito para orientar esta pesquisa e por todos os ensinamentos, não só da teoria piagetiana, mas também acerca de uma atitude epistêmica de diálogo e reflexão.

À Profa. Claudia Broetto Rossetti, pela sua leitura atenta e rigorosa, pelas sugestões na qualificação e pelos significativos momentos acadêmicos compartilhados.

Ao Prof. Rogério Lerner, pelas contribuições realizadas na qualificação, pelas discussões e propostas de diálogo proporcionadas na sua disciplina, que tanto serviram para esta pesquisa.

A Ana Lúcia Petty pela generosidade e entusiasmo para compartilhar sua longa experiência de trabalho e conhecimentos da teoria piagetiana. Obrigada pelas contribuições teóricas e práticas proporcionadas em cada oficina de jogos, e por gerar nelas um espaço de tanta qualidade profissional e respeito com cada uma das crianças.

Ao Prof. Yves De la Taille, pelo privilégio de assistir suas aulas, pela clareza e coerência de seu raciocínio, por se mostrar aberto às perguntas e dúvidas e pelas grandes contribuições de suas reflexões sempre profundas, críticas e originais.

Ao Prof. Lino de Macedo, pela sabedoria de seu ensino, pelos subsídios teóricos e práticos de cada aula, manifestados de maneira lúcida, criativa e inspiradora para continuar pensando o desenvolvimento humano na perspectiva piagetiana.

À Profa. Maria Rita Salzano Moraes pelos três semestres de disciplinas, por transmitir sua paixão pela psicanálise, por seu especial estilo para organizar as aulas, e pela sua rigorosa leitura da obra freudiana, que foi tão significativa e valiosa para realizar este trabalho.

A Camila Folquitto e Tamires Monteiro, pelos nossos diálogos e intercâmbio intelectual, e pela cordialidade e companheirismo em todas as atividades acadêmicas compartilhadas. 
Ao CNPq, pela concessão de uma Bolsa de Mestrado de dois anos, sem a qual este trabalho não teria sido possível.

À Universidade de São Paulo, especialmente ao Instituto de Psicologia, por ter me proporcionado uma experiência universitária de excelência em termos de estrutura material e humana.

Às coordenadoras e professoras das escolas que aceitaram participar da pesquisa, às famílias que permitiram realizar as entrevistas com seus filhos e, muito especialmente, meu sincero agradecimento a cada criança que, com tanto respeito e predisposição, me autorizou entrevistá-la.

A Aline Paim Leonel, pela amizade, pelas nossas longas conversas sobre psicanálise e pelas nossas inesquecíveis e corajosas tentativas de tradução.

A minhas queridas amigas Andre, Ani, Fer, Macu, Mecha e Yani, mulheres talentosas e inteligentes que sempre estão presentes ainda que na distância física. Obrigada pela força, pelo carinho sincero, pela confiança, pela magia e a infinita alegria de cada encontro, e pelo riso interior de cada lembrança.

A Lu, minha amiga da vida, pela sua capacidade de escuta, sempre atenta e honesta, pela alegria de cada conversa e pela confiança de poder crescer e aprender na amizade.

À minha família do Brasil: Dona Izalina e Seu Lúcio, Delma, Dalton, Dalmo e Sulete, Débora, Dayse e Dean, Darlene e Fernanda, Denner, Vânia e Gi. Obrigada por me receber sempre com tanto carinho e por me fazer sentir "em casa".

A meus avôs, Tito e Graciela, e a minha avó Elvira, por serem exemplos de integridade e amor, e por me ajudar sempre, com sabedoria e carinho, a me superar e ser uma pessoa melhor.

A meus pais, Eduardo e Liliana, pelo apoio incondicional, por fomentar minha autonomia com amor e dedicação sincera, pela paciência cotidiana e pela confiança e incentivo em todos meus projetos pessoais e profissionais. 
A meus queridos irmãos, Melina e Andrés, pelo amor fraterno tão único e especial, pela experiência maravilhosa de ter crescido juntos, pela emoção de saber que sempre estamos unidos na diversidade de circunstâncias, e por me conhecer e me re-conhecer em cada um de vocês.

\begin{abstract}
A Davisson, pela confiança, pela paciência, pelo imenso apoio proporcionado ao longo destes anos, por tantas leituras cuidadosas, por me acompanhar nos momentos difíceis e celebrar minhas pequenas conquistas. Obrigada por ser meu companheiro de pesquisas e aprendizagens da vida, por Lux; por me ajudar a crescer em todos os aspectos, e pelo amor e a sincera generosidade manifestados nos pequenos e grandes gestos cotidianos.
\end{abstract}


(...) estou persuadido que chegará o dia em que a psicologia das funções cognitivas e a psicanálise serão obrigadas a se fundir numa teoria que melhorará as duas corrigindo uma e outra, e é esse futuro, que é conveniente prepararmos, mostrando desde agora as relações que podem existir entre as duas.

Jean Piaget, 1970. 


\section{R E S U M O}

Garbarino, M. I. (2012). Crenças sobre a origem dos bebês em crianças de 4 a 9 anos: uma abordagem a partir da psicogênese piagetiana e da psicanálise freudiana. Dissertação de Mestrado, Instituto de Psicologia, Universidade de São Paulo, São Paulo.

A questão da origem dos bebês constitui uma das perguntas mais antigas da humanidade e um enigma existencial que, desde cedo, interessa às crianças. $\mathrm{O}$ tema foi abordado, com distintos focos, por dois dos autores mais relevantes da psicologia: Jean Piaget e Sigmund Freud. Ambas as perspectivas abordam a manifestação da curiosidade sexual infantil e suas perguntas sobre a origem dos bebês como fundadoras de um vínculo particular com o conhecimento. A presente pesquisa tem como objetivo geral investigar as formas e elementos comuns das crenças sobre a origem dos bebês em crianças de 4 a 9 anos por constituir um período de passagem para ambas as teorias. Para a psicogênese piagetiana, contempla a transição entre o pensamento pré-operatório e o operatório concreto. No contexto do desenvolvimento psicossexual postulado pela teoria psicanalítica, esse período considera a passagem da fase fálica ao período da latência. A partir da hipótese de uma possível articulação entre ambos os corpos teóricos, o estudo se propõe explicar e analisar a construção dessas crenças. Para isso, 80 crianças da cidade de Campinas, SP, entre 4 e 9 anos participaram de uma entrevista individual elaborada a partir do método clínico piagetiano. $\mathrm{O}$ procedimento incluiu um questionário semi-estruturado e seis pranchas com ilustrações de contos de fadas e personagens infantis, usadas como recurso "provocador". As perguntas contemplaram, entre outros eixos temáticos, a fecundação, a alimentação intra-uterina, o nascimento e as diferenças sexuais. Os dados coletados foram organizados em dois grupos etários: de 4 a 6 e de 7 a 9 anos. Para analisar as crenças foram levados em conta os aspectos cognitivos e afetivos postulados por Piaget para explicar a construção pré-operatória e operatória do conhecimento. Foram considerados conceitos como egocentrismo e descentração, os estágios do artificialismo e as conseqüências que o vínculo das crianças com seus pais trazem para a qualidade do conhecimento construído. Na perspectiva da psicanálise, foram especialmente considerados os conceitos: teorias sexuais infantis, processos primários e secundários, complexo de Édipo e pulsão de saber. Conseguiu-se detectar diferenças qualitativas significativas entre as crenças das crianças mais novas e das mais velhas, o que confirma a progressão genética da organização mental postulada por Piaget e o desenvolvimento psicossexual teorizado por Freud. A comparação das crenças mostra, em linhas gerais, uma progressão: do concreto (dados perceptivos) ao abstrato, do subjetivo ao objetivo, do egocêntrico ao descentrado e coordenado, e do difuso ao mais preciso. Os resultados contribuem para a discussão acerca da pertinência do diálogo entre conceitos piagetianos e freudianos para melhor compreender a construção do conhecimento sobre a origem dos bebês e a interação de aspectos cognitivos e afetivos no desenvolvimento infantil em geral.

Palavras-chave: Crenças (não-religiosas). Piaget, Jean, 1896-1980. Freud, Sigmund, 18561939. 


\section{A B S T R A C T}

Garbarino, M. I. (2012). Beliefs about the origin of babies in children from 4-9 years old: an approach based on Piagetian psychogenesis and Freudian psychoanalysis. Dissertação de Mestrado, Instituto de Psicologia, Universidade de São Paulo, São Paulo.

The question of the origin of babies is one of the oldest questions of humanity and it is an existential enigma that, since early age, interests children. The topic was discussed taking into consideration perspectives of two significant authors of Psychology: Jean Piaget and Sigmund Freud. Both perspectives address the manifestation of child sexual curiosity and their questions about the origin of babies as founders of a particular relation with knowledge. This research aims to investigate forms and common elements in the beliefs about the origin of babies in children from 4 to 9 years old. This age group corresponds to periods of transition in both theories. For Piagetian psychogenesis, envisages the transition between pre-operative to concrete operative thinking. In the context of psychosexual development, postulated by the psychoanalytic theory, this period is considered the transition from the phallic phase to the period of latency. From the hypothesis of a possible linkage between the two theoretical approaches, the study explained and analyzed the construction of these beliefs. For this, 80 children in Campinas city (SP) participated in individual interviews based on the Piagetian clinical method. The procedure included a semi-structured questionnaire and six boards with illustrations of fairy tales and cartoon characters, used as a "provocative" resource. The issues contemplated themes such as fecundation, intrauterine nutrition, birth and sex differences. The data collected was organized into two age groups: from 4 to 6 and from 7 to 9 years. To analyze the children's beliefs cognitive and affective aspects postulated by Piaget to explain the construction of pre-operative and operative knowledge were taken into account. Concepts such as egocentricity and decentration, stages of artificiality and the consequences that the relation between children and their parents bring to the quality of knowledge constructed were considered. From the psychoanalitical point of view, concepts of children's sexual theories, primary and secondary processes, Oedipus complex and knowledge drive were especially considered. It was able to detect significant qualitative differences between the beliefs of the younger children and the elder ones, which confirms the genetic progression of mental organization proposed by Piaget and the psychosexual development theorized by Freud. The comparison of beliefs in general shows a progression from the concrete (perceptual data) to the abstract, the subjective to the objective, the egocentric thinking to the decentred and coordinated thinking, and from a diffuse to a more precise view. Results contribute to the discussion about the relevance of the dialogue between Piagetian and Freudian concepts to better understand the construction of the knowledge about the origin of babies and the interaction of cognitive and affective aspects in child development.

Keywords: Beliefs (nonreligious). Piaget, Jean, 1896-1980. Freud, Sigmund, 1856-1939. 


\section{LISTA DE QUADROS}

Quadro 1. Níveis das crenças em relação à fecundação

Quadro 2. Níveis das crenças em relação à alimentação intra-uterina .................................. 113

Quadro 3. Níveis das crenças em relação ao nascimento .................................................... 121

Quadro 4. Níveis das crenças em relação às diferenças sexuais ........................................... 127

Quadro 5. Níveis de crenças sobre fontes de informação ...................................................... 137

Quadro 6. Síntese das principais tendências observadas a partir dos resultados.................... 151

\section{LISTA DE TABELAS}

Tabela 1. Distribuição das crianças, em freqüência absoluta e percentual, por idade.............. 88

Tabela 2. Distribuição das crianças, em freqüência absoluta e percentual, por sexo................88

Tabela 3. Distribuição das crianças, em freqüência absoluta por sexo e idade em anos.......... 88

Tabela 4. Distribuição das crianças em freqüência absoluta por sexo por grupo etário ...........88

Tabela 5. Distribuição de freqüência absoluta e percentual das crenças sobre fecundação por

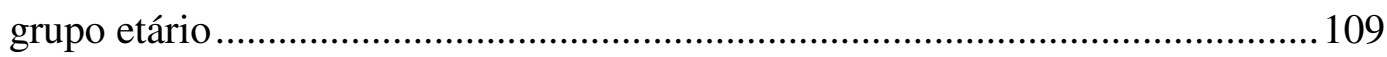

Tabela 6. Distribuição percentual das crenças sobre fecundação em cada nível. ...................111

Tabela 7. Distribuição de freqüência absoluta e percentual das crenças sobre alimentação intra-uterina por grupo etário

Tabela 8. Distribuição de freqüência absoluta e percentual das crenças sobre alimentação intra-uterina por sexo das crianças

Tabela 9. Distribuição percentual das crenças sobre alimentação intra-uterina em cada nível

Tabela 10. Distribuição de frequiência absoluta e percentual de cada nível de crença sobre o nascimento por grupos etários.

Tabela 11. Distribuição percentual de cada nível de crenças sobre nascimento 126

Tabela 12. Distribuição comparativa da freqüência absoluta e percentual das crenças sobre as diferenças sexuais por grupos etários

Tabela 13. Distribuição percentual das crenças sobre diferenças sexuais em cada nível. ..... 135

Tabela 14. Distribuição da frequiência absoluta e percentual dos níveis de crenças sobre diferenças sexuais, de acordo com o sexo das crianças 
Tabela 15. Distribuição de freqüência absoluta e percentual das crenças sobre fontes de informação por grupo etário

Tabela 16. Distribuição percentual das crenças sobre fontes de informação em cada nível.. 142

\section{LISTA DE FIGURAS}

Figura 1. Distribuição comparativa das freqüências de crenças sobre fecundação de cada nível por grupo etário

Figura 2. Distribuição percentual das crenças sobre fecundação em cada grupo etário .........110

Figura 3. Distribuição percentual das crenças sobre fecundação em cada nível.

Figura 4. Distribuição comparativa da freqüência percentual de cada nível de crença sobre alimentação intra-uterina por grupo etário

Figura 5. Distribuição percentual das crenças sobre alimentação intra-uterina em cada grupo etário

Figura 6. Distribuição percentual das crenças sobre alimentação intra-uterina em cada nível

Figura 7. Distribuição comparativa da freqüência percentual de cada nível de crença sobre nascimento por grupos etários.

Figura 8. Distribuição percentual dos níveis de crenças sobre nascimento, em cada grupo etário

Figura 9. Distribuição percentual de cada nível de crença sobre nascimento 127

Figura 10. Distribuição comparativa da freqüência percentual das crenças sobre as diferenças sexuais por grupos etários

Figura 11. Distribuição percentual dos níveis de crenças sobre diferenças sexuais em cada grupo etário

Figura 12. Distribuição percentual de cada nível de crença sobre diferenças sexuais.

Figura 13. Distribuição comparativa da freqüência percentual de crenças sobre diferenças sexuais do mesmo nível para cada grupo etário

Figura 14. Distribuição percentual das crenças sobre fontes de informação em cada grupo etário

Figura 15. Distribuição percentual das crenças sobre fontes de informação em cada nível .. 142 


\section{S U M Á R I O}

1. INTRODUÇÃ

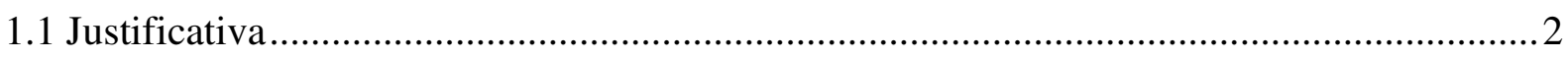

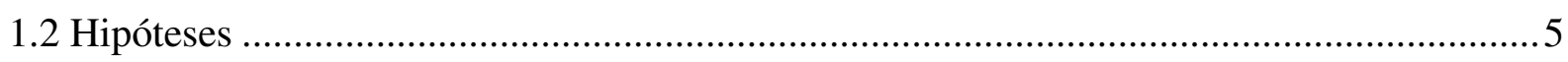

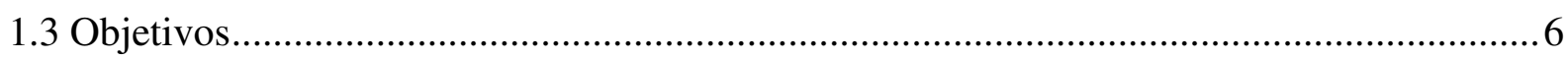

1.4 Aspectos sócio-históricos da fecundação e da sexualidade................................................

2. DESENVOLVIMENTO COGNITIVO E AFETIVO DA CRIANÇA NA TEORIA

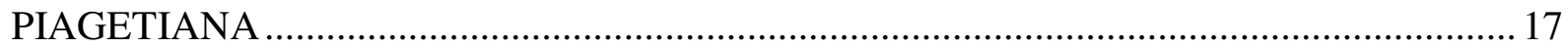

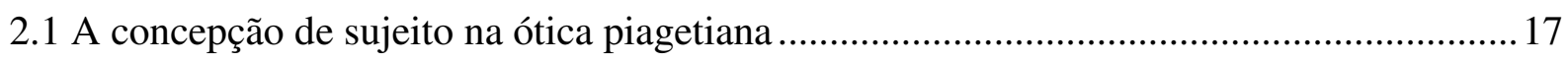

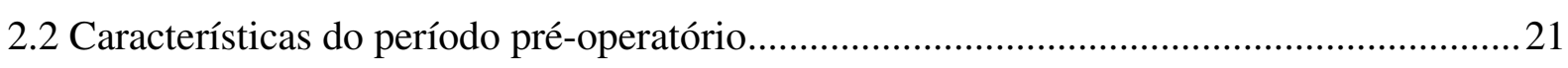

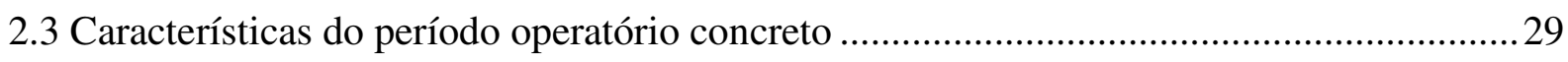

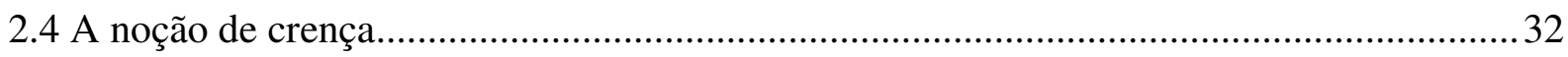

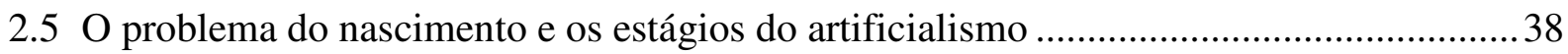

3. DESENVOLVIMENTO PSICOSSEXUAL DA CRIANÇA NA PERSPECTIVA

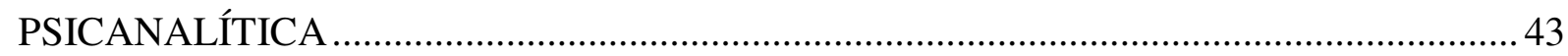

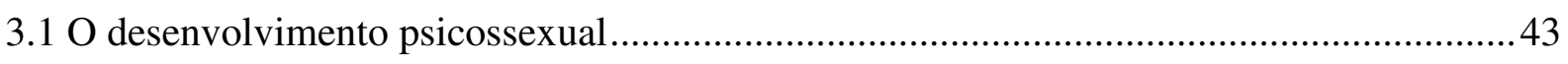

$3.2 \mathrm{O}$ complexo de Édipo como primeiro conflito psíquico ............................................... 46

3.3 Aspectos psicodinâmicos do pensamento e adaptação à realidade ................................... 47

3.4 Relações de cooperação entre os sistemas e a função do Ego ...........................................50

3.5 Teorias sexuais infantis: desejo de saber sobre a origem e origem do desejo de saber......54

3.6 Outros aportes psicanalíticos sobre as teorias sexuais infantis........................................65

4. O DIÁLOGO ENTRE AS TEORIAS PIAGETIANA E FREUDIANA............................. 74

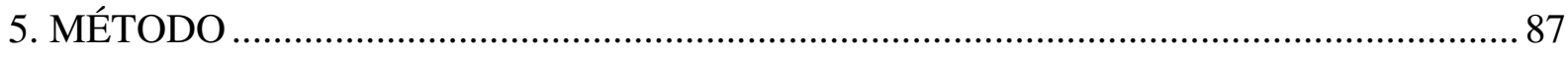

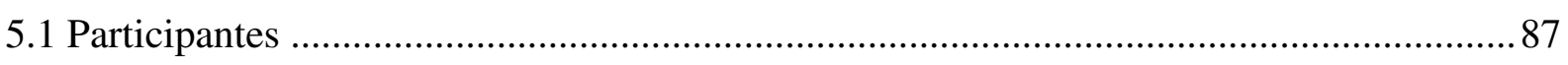

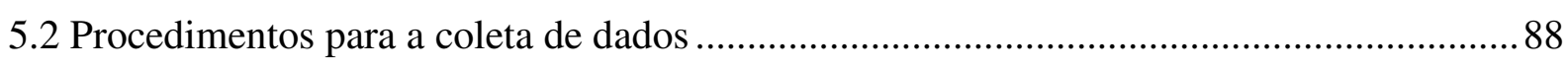

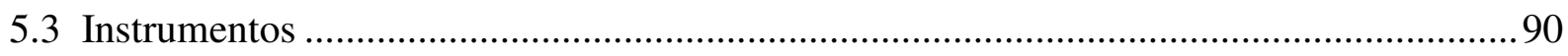

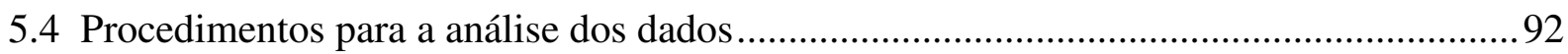

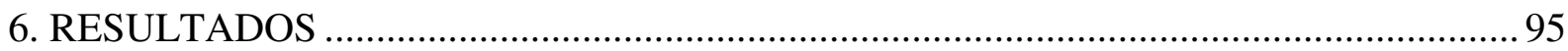

6.1 Crenças sobre a fecundação: do pré-formismo à epigênese ............................................ 96

6.2 Crenças sobre a alimentação intra-uterina: do egocentrismo integral ao artificialismo

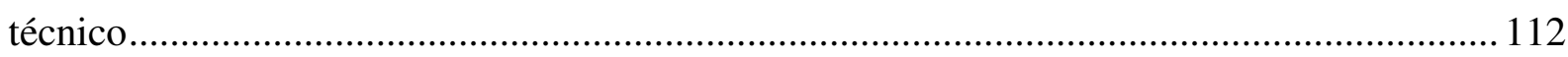

6.3 Crenças sobre o nascimento: do corte da barriga à consideração da vagina .................... 121 
6.4 Crenças sobre diferenças sexuais: do gênero à anatomia

$6.5 \mathrm{O}$ pensamento da criança: entre o símbolo e a lógica.

7. DISCUSSÃO

8. CONSIDERAÇÕES FINAIS 165

REFERÊNCIAS . 168

ANEXOS 174

I) Roteiro da entrevista 174

II) Pranchas ilustradas 175

III) Autorização assinada pelos pais. 177

IV) Aprovação do Comitê de Ética 179 


\section{INTRODUÇÃO}

A pergunta sobre a origem dos bebês pode ser considerada como um dos mais antigos enigmas da humanidade e dificilmente alguma criança deixa de se perguntar acerca de como apareceu no mundo. O problema da fecundação e do nascimento resulta num tema complexo porque se refere à própria existência, ao desejo dos pais, à continuação da espécie, à possibilidade de se projetar como possível procriador, à morte e ao ciclo da vida em geral.

Jean Piaget e Sigmund Freud revolucionaram a concepção de criança de sua época. O primeiro, entendendo que ela manifesta formas de inteligência desde muito cedo; o segundo, admitindo a sexualidade infantil. Para os dois autores, desde bebê, a criança constrói a base das manifestações adultas posteriores, cognitivas para um, psicossexuais para o outro. Em ambos, a infância constitui um período de enorme dinamismo que é pedra angular para entender todos os períodos posteriores do desenvolvimento humano, considerando-o, assim, como uma espiral que integra e nunca abre mão de conquistas prévias.

A partir da perspectiva de desenvolvimento ontogenético, pode-se afirmar que a necessidade de verificação não é inata no ser humano, mas é uma conquista de um longo processo cognitivo e afetivo de descentração, que começa nas suas formas mais rudimentares a partir do nascimento. Uma das características do conhecimento científico (que constitui um entre outros tipos de conhecimento possíveis) é que ele se sustenta na necessidade de verificação. A esse respeito, Piaget assinala que a criança brinca, crê nas coisas, mas sem investigar de forma sistemática. $\mathrm{O}$ autor se pergunta:

Como nasce, portanto, a necessidade de verificação? Seguramente, é o choque de nosso pensamento com o dos outros que produz em nós a dúvida e a necessidade de provar. Sem os outros, as decepções da experiência nos levariam a uma supercompensação de imaginação e ao delírio. Constantemente, nasce dentro de nós um número enorme de idéias falsas, de extravagâncias, de utopias, de explicações místicas, de suspeitas e de megalomanias que caem ao contato com os outros. É a necessidade social de compartilhar o pensamento dos outros, de comunicar o nosso e de convencer, que está na origem de nossa necessidade de verificação. A prova nasceu da discussão (Piaget, 1924/1947, p.196, o negrito é nosso).

Essa citação é pertinente para posicionar o presente trabalho em seus objetivos, e em suas dimensões teórica e metodológica. Partindo da necessidade de verificação, o presente estudo é resultado do diálogo entre as teorias escolhidas e os dados coletados no campo. Nas crianças, a conquista das atitudes mentais adequadas para a construção do conhecimento científico é produto de um longo processo que parte de crenças e explicações míticas que, no 
início, não precisam ser comunicadas aos outros. De acordo com Piaget, sem o "fator social" essa passagem não seria possível, e conseqüentemente, não haveria necessidade da ciência.

A afirmação de Piaget alude a um dos objetivos específicos a que este trabalho se propõe: o estudo da passagem do pensamento pré-operatório ao operatório concreto a partir da progressão genética dos conhecimentos sobre a origem dos bebês e dos aspectos afetivos envolvidos nesse processo. Essa passagem implica o percurso desde uma forma pré-lógica e intuitiva de entender a realidade para outra lógica, reversível e mais coordenada que permite à criança construir o conhecimento por meio de operações. Essa conquista é crucial no desenvolvimento da criança não só para atingir níveis de melhor qualidade na sua interação com o mundo, mas também porque o meio social lhe exige ingressar e ser bem sucedida na escola, onde passa grande parte da sua infância e adolescência. Essa instituição lhe demanda e fomenta (no melhor dos casos) a construção de conhecimentos científicos, impondo uma dinâmica de trabalho estruturada a partir do ensino de conteúdos que foram construídos cientificamente e transmitidos historicamente como patrimônio cultural.

Na perspectiva da psicanálise a criança também atravessa um período de transição entre duas formas de organização psicossexual: da fase fálica ao período de latência. Esses modos de organização da libido têm repercussões no pensamento da criança e no modo de se relacionar com o mundo e especialmente com os pais. Acrescenta-se a circulação da criança por diversos contextos institucionais como a família e a escola, nas quais constrói vínculos afetivos de qualidades diversas com os adultos e seus pares.

\subsection{Justificativa}

A análise dos conhecimentos que as crianças constroem sobre a sexualidade exige ferramentas conceituais que abordem diferentes aspectos do desenvolvimento. Este estudo se situa na linha de pesquisa que se ocupa da interação entre inteligência e afetividade no desenvolvimento da criança. Fundamenta-se nas contribuições da psicogênese e da psicanálise, por serem teorias já consagradas nas pesquisas sobre a construção do conhecimento e o desenvolvimento psicossexual das crianças, respectivamente, e pelo fato de ambas terem trabalhado a propósito do tema das crenças e teorias infantis acerca da origem dos bebês. A primeira baseia sua teoria nos fatores cognitivos e afetivos implicados na construção do conhecimento, especialmente a partir de estruturas lógico-matemáticas. A segunda focaliza os aspectos psicossexuais e relacionais da constituição do aparelho psíquico e as "formações do inconsciente". 
A opção teórica e metodológica desta pesquisa pela epistemologia genética piagetiana se dá pelo fato de que esta permite entender a constituição do sujeito epistêmico e a progressão genética da qualidade do conhecimento construído. A pergunta que orientou as pesquisas de Piaget foi saber como o sujeito, ao longo do seu desenvolvimento ontogenético, vai passando de um estágio de menor qualidade de conhecimento (egocêntrico, difuso, prélógico) para outro qualitativamente superior (descentrado, coordenado e objetivo). Todavia, esse conhecimento estudado por Piaget não é qualquer conhecimento, pois precisa de atitudes mentais específicas. Trata-se do conhecimento científico, que se caracteriza pela necessidade de comprovação. Benbenaste (2005, p. 30-31) diferencia o conhecimento científico de outros dois tipos. Por um lado, do conhecimento místico, no qual predomina a vivência e não o raciocínio porque o sujeito não é diferenciado do objeto e tende a identificar-se com ele. Por outro, do conhecimento metafísico no qual o sujeito é discriminável, mas não o objeto, porque não é empiricamente constatável.

A opção pela psicanálise freudiana se fundamenta por esta ser uma teoria que coloca a sexualidade como um elemento constitucional no desenvolvimento geral do ser humano. Esta teoria focaliza as repercussões afetivas e intelectuais das fases psicossexuais que se sucedem durante a infância. Se para Piaget o conhecimento precisa da afetividade (entendida como energética e motivação da sua construção), a psicanálise explica a dinâmica dessa energia a partir dos conceitos de libido, pulsão e desejo. A libido é uma energia móvel e dinâmica que atravessa processos de desenvolvimento e reorganização em torno de um suporte biológico (como alimentação, excreção, masturbação, etc.). Nas palavras de Freud:

\footnotetext{
Uma pulsão nos aparecerá como sendo um conceito situado na fronteira entre o mental e o somático, como o representante psíquico dos estímulos que se originam dentro do organismo e alcançam a mente, como uma medida da exigência feita à mente no sentido de trabalhar em conseqüência de sua ligação com o corpo (Freud, 1915/1996, p. 127).
}

Laplanche e Pontalis (2009) lembram que a palavra pulsão (trieb em alemão) é uma noção energética que aparece nos textos freudianos a partir de 1905. Constitui uma excitação interna, mola do funcionamento do aparelho psíquico. Os autores ressaltam que a teoria das pulsões foi sempre dualista (pulsões sexuais e pulsões do ego ou de auto-conservação; pulsões de vida e pulsões de morte) em referência a uma grande oposição fundamental "tomada da tradição mítica: oposição entre a fome e o amor, e mais tarde entre o amor e a discórdia" (Laplanche e Pontalis, 2009, p. 327).

A faixa etária das crianças abarca o intervalo de 4 a 9 anos. A decisão de não entrevistar crianças menores de 4 anos se fundamentou, inicialmente, na sugestão piagetiana 
de utilizar o método clínico com crianças a partir dessa idade. Para conseguir uma avaliação mais significativa da progressão genética da construção dos conhecimentos, foi considerada uma faixa de 6 anos. Por último, vale destacar que esta faixa etária corresponde a um período de transição para as duas teorias. Na ótica piagetiana, inclui a "fronteira de passagem" entre o fim do período pré-operatório do pensamento e o início do período operatório concreto. $\mathrm{Na}$ perspectiva freudiana, contempla a saída da fase fálica e o início do período de latência. Essa dupla transição permite uma análise de dados de acordo com os objetivos do trabalho. Ainda que essa faixa etária contemple a transição já mencionada em um desenvolvimento "típico", é importante ressaltar que para ambos os marcos teóricos, as idades são sempre relativas e aproximadas.

Os principais referenciais teóricos da pesquisa correspondem a conceitos retirados de textos selecionados da vasta obra de Piaget e de Freud. Os critérios para essa seleção foram a faixa etária estudada e as ferramentas conceituais necessárias para entender a construção das crenças sobre a origem dos bebês. A escolha do tema se justifica pelo fato de ter sido um objeto de estudo tanto freudiano como piagetiano. Tanto a psicogênese como a psicanálise explicam as regularidades e as tendências gerais das tentativas das crianças para explicar a origem dos bebês. Os objetivos do trabalho focalizam os aspectos cognitivos e afetivos da construção desse conhecimento e não as práticas educativas dos adultos e professores ou o papel da escola na abordagem ou repressão da sexualidade. Porém, como nos conteúdos das entrevistas o fator social aparece, é possível que a pesquisa possa realizar contribuições para refletir acerca dos alcances e limites da função educativa dos pais e professores que constantemente observam situações lúdicas e intervenções verbais sobre o tema.

Assim, a escolha dos autores se justifica por suas concepções de desenvolvimento que permitem entender a constituição subjetiva e mental da criança a partir de um processo multideterminado. Em sua teoria, Piaget considerou a existência de quatro fatores do desenvolvimento: maturação, experiência física, interação social e equilibração (1966/1972, p. 156). Para Freud, a base para entender o desenvolvimento psicossexual contempla a constituição orgânica e sexual da criança, suas conseqüências psíquicas e as vivências acidentais. Nessa linha, este estudo se apóia na concepção de que a criança se desenvolve em contínua interação com seu entorno físico e social e se posiciona ativamente na assimilação

\footnotetext{
${ }^{1}$ A noção de desenvolvimento típico é importante em ambos os autores. Ainda que a psicanálise se fundamente na psicopatologia, Freud precisou estabelecer um desenvolvimento "habitual" que fosse parâmetro para estudar as neuroses, já que o limite entre o patológico e o normal resulta difuso para este autor. Piaget não se dedicou a estudar desenvolvimentos atípicos ainda que tenha realizado menções sobre crianças surdas e cegas, e atualmente numerosas pesquisas contemporâneas no contexto do desenvolvimento atípico demonstram a pertinência de utilizar a psicogênese piagetiana como marco teórico de pesquisa.
} 
do mundo e de suas experiências. Tal como sustentam Camargo e Ribeiro (1999), a partir de dois anos as crianças percebem as diferenças entre os sexos, manifestam curiosidade sobre a reprodução e o nascimento, falam sobre namoro, participam de jogos sexuais e compartilham informações sobre sexo. Tudo isso independentemente do adulto querer ou não, porque o grupo de colegas constitui uma fonte de informação e de resistência a sua censura.

A presente pesquisa visa articular a contribuição da psicogênese e da psicanálise por considerar que ambas se distanciam dos dualismos corpo-mente e afetividade-inteligência que levam a reducionismos na interpretação dos processos cognitivos e afetivos do desenvolvimento humano. A dialética que organiza a psicogenética piagetiana permite pensar relações de interdependência entre estrutura-gênese e sujeito-objeto. Nos conceitos de séries complementares e de processos primários e secundários ${ }^{2}$ do aparelho psíquico propostos por Freud também subjaz um enfoque dialético do desenvolvimento do sujeito. Os dois corpos teóricos admitem refletir acerca dos alcances e limites do fator social, e especialmente da educação, em confronto com algumas resistências estruturais do pensamento egocêntrico e com o caráter de preferência pulsional das teorias sexuais infantis. Para ambos os autores, a tenacidade das convicções das crianças persiste, apesar da observação de fatos contraditórios a sua crença e da influência dos discursos dos adultos.

Piaget postula que a afetividade constitui a energética na construção dos conhecimentos. Ainda que não tenha aprofundado o tema, o autor tenta explicar os esquemas afetivos como reguladores dessa energética. Essa idéia se apóia na postulação de que "a afetividade constitui a energética das condutas cujas estruturas correspondem às funções cognoscitivas, e se a energética não explica a estruturação, nem o inverso, nenhuma das duas poderia funcionar sem a outra" (Piaget \& Inhelder, 1966/1972, p. 116) ${ }^{3}$. A interpretação e análise dos dados coletados nesta pesquisa se justificam pela necessidade de aprofundar empiricamente o estudo dessa afirmação.

\subsection{Hipóteses}

Os dados coletados na presente pesquisa sobre o tema da construção das crenças sobre a origem dos bebês serão utilizados para problematizar duas hipóteses:

\footnotetext{
${ }^{2}$ Os conceitos de séries complementares, processos primários e secundários serão desenvolvidos mais adiante.

${ }^{3}$ Todas as traduções do espanhol, do francês e do inglês ao português são da autora.
} 
1. Os processos estruturais do desenvolvimento cognitivo e afetivo da criança estudados por Piaget na transição do pensamento pré-operatório ao operatório concreto corresponderiam aos aspectos psicodinâmicos do pensamento e os conflitos psíquicos do desenvolvimento psicossexual postulados por Freud na passagem da fase fálica ao período de latência.

2. Considerar uma abordagem teórica que contemple a psicogênese piagetiana e a psicanálise freudiana pode enriquecer a compreensão da construção das crenças sobre a origem dos bebês e a discussão sobre a interação entre inteligência e afetividade na construção do conhecimento em geral. Conseqüentemente, o diálogo entre ambas as teorias possibilitaria ampliar as ferramentas de análise e entendimento de problemas próprios ao desenvolvimento humano.

\subsection{Objetivos}

Esta pesquisa se enquadra em uma categoria geral de problemas que é a construção do conhecimento. Seu objetivo mais geral é compreender como se constroem as crenças sobre a origem dos bebês nas crianças de 4 a 9 anos e qual é a sua progressão genética em relação ao desenvolvimento da inteligência e da afetividade. Nesse sentido, o trabalho visa propor uma discussão com base na análise das formas e elementos gerais da construção das crenças em correspondência com os fatores afetivos que as motivam a partir de conceitos piagetianos e freudianos. A partir deste objetivo geral e das hipóteses estabelecidas, foram propostos os seguintes objetivos específicos:

1. Entender a progressão genética dos conhecimentos sobre a origem dos bebês levando em consideração tanto os crescentes níveis de qualidade da inteligência e da afetividade quanto as fases do desenvolvimento psicossexual predominantes na faixa etária contemplada, entendida como um período de transição entre duas formas de organização mental e sexual.

2. A partir do caso específico dessa progressão genética, estudar as repercussões da passagem do pensamento pré-operatório ao operatório como correspondente à da fase fálica ao período de latência, especialmente no que diz respeito às atitudes cognitivas e afetivas necessárias para a construção do conhecimento científico.

3. Apresentar alguns elementos levantados por Piaget no diálogo que manteve com a psicanálise ao longo de sua obra e analisar as suas implicações para entender o recorte 
do objeto da pesquisa e as características cognitivas e afetivas da fase de transição escolhida.

4. Problematizar os limites e alcances de uma abordagem que contemple a psicogênese piagetiana e a psicanálise freudiana à luz dos dados coletados e dos atuais estudos sobre inteligência e afetividade como aspectos indissociáveis do desenvolvimento.

\subsection{Aspectos sócio-históricos da fecundação e da sexualidade}

Esta pesquisa parte de uma concepção interacionista do desenvolvimento, segundo a qual é possível afirmar que o conhecimento se constrói a partir da interação Sujeito-Objeto. Sendo assim, além de considerar o desenvolvimento do sujeito (as crianças de 4 a 9 anos), também é preciso assinalar algumas especificidades do objeto (fecundação e sexualidade). No presente item serão primeiramente apresentados alguns de seus aspectos sócio-históricos. Os primeiros abordam o meio social e cultural no qual a criança interage; os últimos se referem à historia da ciência e às mudanças de teorias a respeito do problema da fecundação.

Considerar as características sócio-históricas da sexualidade ocidental se justifica pela idéia piagetiana de que estudar o sujeito nos seus aspectos universais de desenvolvimento ontogenético não significa entendê-lo isolado ou afastado do meio no qual se situa e interage. Também não implica em ignorar ou subestimar as características de cada cultura de acordo com o momento histórico que se aborde. Porém, pelos objetivos e marcos teóricos escolhidos, entende-se que, embora essas particularidades culturais e históricas possam constituir variações de conteúdo na construção do conhecimento e no desenvolvimento afetivo da criança, também existem formas de pensamento, conflitos e mecanismos intra-psíquicos e relacionais que permanecem estáveis dentro da variabilidade desses contextos.

A quantidade e a qualidade das informações acerca da sexualidade mudaram bastante da época em que Piaget e Freud estudaram o tema. Hoje as crianças estão muito mais expostas a diversas fontes de informação acerca da fecundação e do nascimento. Porém, as crianças de hoje são mais "sabidas"? Os dados aqui coletados apóiam a idéia de que, a despeito dessas mudanças do meio, existem tendências universais e estruturais no processo de construção dessas crenças, que se mantém ao longo do tempo por ser conseqüências de processos típicos do desenvolvimento da criança. A presente pesquisa focaliza e avalia o aspecto estável do desenvolvimento no contexto das mudanças sociais. 
O levantamento bibliográfico realizado permitiu identificar dois grupos de trabalhos na área da sexualidade infantil. O primeiro coloca ênfase na psicologia das diferenças sexuais e da constituição das identidades de gênero (Le Maner, 1997; Katchadourian, 1993; Brougère, 1999). O segundo grupo é composto por pesquisas sobre educação sexual que enfatizam aspectos sociais da contemporaneidade (Camargo e Ribeiro, 1999; Moreno, 1999; Guimarães, 1995; Nunes e Silva, 2000; Calderone e Ramey, 1986). Ainda que na maioria destes trabalhos possam ser reconhecidas as teorias freudiana e piagetiana como os principais aportes psicológicos do tema, o enfoque se direciona ao "fator social", ou seja, aos preconceitos de professores e pais, aos estereótipos fomentados pelas escolas, à vulgarização da sexualidade humana na mídia e à ausência ou distorções de explicações ao problema da origem dos bebês e da sexualidade em geral.

O problema do nascimento corresponde ao campo do conhecimento biológico ou social? Segundo Delval (2007), este fenômeno deve contemplar os dois aspectos: "o nascimento e a morte, ademais de fenômenos biológicos são fenômenos sociais, os jovens, os adultos e os velhos tem um papel na sociedade e cada sociedade lhes outorga um lugar" (p. 14). O autor assinala também que a concepção de família, as relações de parentesco e as funções paterna e materna estão relacionadas com os papéis sexuais. A adoção de papéis sexuais tem sido pouco estudada em seus aspectos cognitivos, prevalecendo as análises sociológicas.

Piaget não desconsidera a importância do contexto social no desenvolvimento infantil. As interações e transmissões sociais constituem importantes fatores, ao mesmo tempo cognitivos e afetivos. Porém, ainda que sejam essenciais, não são suficientes por si mesmos, porque a ação social é ineficaz sem uma assimilação ativa da criança. Na ótica piagetiana, a mediação universal do ser humano é a ação. Assim, a criança age mental e fisicamente para assimilar a informação que recebe do meio em um processo recíproco de socialização progressiva (Piaget \& Inhelder, 1966/1972). O conteúdo do pensamento infantil sempre tem duas partes: "uma de influência adulta e uma de reação original da criança. Ou seja, as crenças infantis são o produto de uma reação influenciada, mas não ditada pelo adulto" (Piaget, 1926/2005, p. 28). Sendo assim, para entender a "sua parte influenciada" é preciso considerar algumas características da sexualidade no contexto social atual.

Para Freud, também há um elemento irredutível de caráter universal em toda experiência humana: o inconsciente. Esse fator "comum a todos" é constituído, ademais, pelas exigências que as pulsões colocam ao psiquismo. A respeito dessa temática, Coelho Jr. (2002) comenta que a teoria freudiana mantém uma tensão "entre propostas de generalização e busca incessante da singularização. A psicanálise freudiana constitui-se como uma elaborada teoria 
do funcionamento psíquico e de seus distúrbios, com pretensões universais" (ibid, p. 34). Segundo o autor, o inconsciente e as pulsões realizam as necessárias mediações entre o sujeito e a realidade.

Quais são as características da realidade sexual contemporânea? Analisar a cultura sexual brasileira é uma longa empreitada que escapa aos objetivos e limites deste trabalho. Entretanto, é preciso admitir que as práticas e crenças arraigadas nas idiossincrasias do povo têm uma história complexa, condicionada por diversos fatores. As instituições religiosas, por exemplo, sempre participaram da constituição dessas crenças e atualmente continuam presentes na vida cotidiana dos indivíduos, influenciando seus valores morais, indicando os preceitos de uma vida boa e o correto modo de atuar e pensar para atingi-la. A educação religiosa das crianças foi manifestada em várias entrevistas nas quais, por exemplo, se apela à figura de um "papai do céu” para explicar a fecundação.

O tema da sexualidade, presente na mídia, nas escolas e na família é atualmente abordado a partir de diversas ideologias, posições pedagógicas e epistêmicas (às vezes contraditórias para a mesma criança). Alguns eventos sugerem o início de um processo de mudanças de alguns dos paradigmas da nossa cultura sexual como a homofobia, o casal parental heterossexual e o sexismo. A respeito da homofobia, por exemplo, na Inglaterra se cogitou a idéia de incluir contos com casais gays na pré-escola ${ }^{4}$, o que desencadeou bastante controvérsia por tratar de um tema considerado tabu no âmbito escolar. Em relação ao paradigma do casal parental heterossexual, por exemplo, na Argentina e no Brasil, a legalização do casamento gay provocou intensos debates, especialmente com a Igreja Católica, diante da ameaça de ruptura do padrão de família monogâmica patriarcal. Em relação ao sexismo, alguns preconceitos estão começando a ser combatidos no mundo da literatura infantil com a aparição dos denominados "novos contos de fadas". Eles apresentam princesas independentes que não querem se casar e preferem atividades historicamente destinadas aos homens, assim como príncipes que gostam de cozinhar e não se mostram sempre fortes e valentes.

Além disso, pode se afirmar que no início do século XXI houve uma proliferação dos debates acerca das possibilidades e limitações psíquicas que propiciam a mídia e as novas tecnologias. As pesquisas mostram controvérsias acerca do uso e abuso da internet e da televisão, especialmente no caso de crianças e adolescentes. Nas entrevistas realizadas várias crianças manifestaram terem visto partos exibidos na televisão e bebês em ultrassons (na vida

\footnotetext{
${ }^{4}$ http://www.bbc.co.uk/portuguese/reporterbbc/story/2007/03/070312_historiasgay_ir.shtml
} 
real e em novelas). Contudo, a mídia e a tecnologia nem sempre apresentam aspectos positivos. O fenômeno do consumo midiático exacerbado que capta a atenção de sociólogos, psicólogos e outros pesquisadores das ciências humanas constitui um dos maiores sintomas da sociedade e também alcançou com força o campo da sexualidade nas suas representações, estéticas, preconceitos e hábitos. Todas as faixas etárias da população estão expostas a elementos e práticas sexuais presentes na programação televisiva, nos produtos oferecidos nas publicidades e na internet.

O modo pelo qual se expõe a informação referida à sexualidade humana também é questionado por alguns autores da psicanálise. Segundo Schejtam (2007) atualmente proliferam as imagens "fetichizadas" e o fetichismo da imagem oferecida na televisão e na internet. Para este autor, o turismo sexual no terceiro mundo e a pedofilia da imagem são outros fenômenos acentuados no nosso tempo. Embora eles sejam condenados pelos direitos da criança, evidencia-se o usufruto da proliferação de imagens de meninas quase púberes em situações sexuais provocadoras.

Sob a aparência de despudor e liberdade sexual, o mercado e a mídia indicam como, quando e onde vivenciar uma sexualidade plena e saudável para responder aos estereótipos sexuais que propiciarão um estado de bem-estar e satisfação oferecido de modo padronizado. Essa liberdade sexual fictícia é discutida por Foucault na obra História da sexualidade (Foucault, 1988/2010). Segundo Nunes (1998) a linha de análise foucaultiana apresenta a dialética do saber e do poder mostrando que: "a lógica de poder da civilização contemporânea faz justamente o jogo repressivo ao contrário de seus ritos iniciais, pretende liberar sexualmente os indivíduos para melhor controlá-los através de eficientes dispositivos institucionais e dos saberes que destas decorrem" (ibid, p. 15).

Na perspectiva de Foucault (1988/2010), a partir do século XVIII, um dos quatro grupos estratégicos que desenvolve dispositivos de saber e poder sobre o sexo é a pedagogização do sexo da criança. Esta contempla que todas as crianças se dediquem a uma atividade sexual indevida e ao mesmo tempo natural, que traz perigos físicos e morais, coletivos e individuais. Um grande expoente dessa pedagogização foi a "guerra contra o onanismo". Para Foucault, a sexualidade é um elemento das relações de poder entre jovens e velhos, pais e filhos, educadores e alunos. O autor afirma que:

a idéia, por exemplo, de muitas vezes se haver tentado por diferentes meios reduzir todo o sexo à sua função reprodutiva, à sua forma heterossexual e adulta e à sua legitimidade matrimonial não explica, sem a menor dúvida, os múltiplos objetivos visados, os inúmeros meios postos em ação nas políticas sexuais concernentes aos dois sexos, às diferentes idades e às classes sociais (ibid, p. 114). 
A idéia de um aumento da liberdade sexual na contemporaneidade é pertinente nesta pesquisa porque a partir dos dados coletados se pode perceber que há algo da sexualidade que resiste e não corresponde a esta suposta supressão dos tabus. Muitas crianças mostraram vergonha para nomear os genitais, as palavras "vagina" e "pênis" são evitadas e recebem pseudônimos como "a parte íntima" ou se deixam supor implícitas detrás de risos de pudor. Por que então, ainda no século XXI, falar sobre sexo pode resultar tão problemático?

No âmbito escolar, a "orientação sexual" constitui hoje uns dos objetivos do MEC proposto como eixo transversal. Porém, na instituição escolar existem diversas posições dos professores que podem funcionar como prolongamento da família e reforço de seus valores, como meio de abertura de horizontes para a criança na linha de sua emancipação, ou como agente moralizador ou informador (Guimarães, 1995). Por sua vez, os conhecimentos e experiências familiares em relação à sexualidade variam ainda nas crianças de uma mesma escola. Características socioeconômicas também apresentam diferentes possibilidades de vivências na infância. Por exemplo, pode-se mencionar uma intervenção psicanalítica realizada no contexto de uma experiência de trabalho em uma favela argentina. Por causa do tamanho reduzido das casas e as precárias condições arquitetônicas, os membros das famílias dessa comunidade dormiam juntos no mesmo quarto. A sugestão dos psicanalistas foi colocar um lençol para criar um limite simbólico entre o espaço dos adultos e das crianças. ${ }^{5}$ Nesses contextos sociais específicos pode-se problematizar, por exemplo, os alcances da teoria sexual da concepção sádica do coito e refletir acerca de até que ponto poderia ser intensificada ou não pelo fato de compartilhar o mesmo quarto entre adultos e crianças e quais seriam essas conseqüências psíquicas na ótica da psicanálise.

A respeito do sexismo, para o público infantil continua havendo prevalência de estereótipos de gênero na indústria dos brinquedos. Já em 1933, Freud sustentava que nas brincadeiras anteriores à fase fálica (antes dos três anos, aproximadamente) as meninas manifestam impulsos agressivos tanto quanto os meninos, e sugeria que as normas sociais influenciam e forçam a mulher a situações passivas. Essas normas sociais são atualmente fortalecidas pela indústria dos brinquedos, que continua estimulando clichês sexistas com brinquedos "para meninas", com temáticas domésticas e bonecas relacionadas aos cuidados maternos. O império rosa e banal de Barbie e outras bonecas similares continua sendo um fenômeno crescente em vendas que promove o culto à vaidade, à riqueza e ao corpo perfeito

\footnotetext{
${ }^{5}$ Relato de palestrante durante as Jornadas "Centenário Dolto"/Primer Encuentro Rioplatense" (Buenos AiresARG), promovido pela Casa Verde da Argentina, de 21 a 23 de novembro 2008.
} 
(branco, loiro, magro e ocidental). No caso dos brinquedos "para meninos" proliferam carrinhos, armas e bonecos lutadores que fomentam o estereótipo da agressividade e evocam aparatos militares de guerra.

É preciso lembrar que nem sempre existiram as concepções de criança e de sexualidade hoje predominantes. No livro A história social da criança e da família, Philippe Ariès (1973/1981) dedica um capítulo à concepção de criança em relação à sexualidade intitulado "Do despudor à inocência", no qual é apresentada uma diversidade de exemplos de uma explícita manifestação da sexualidade em brincadeiras entre crianças e adultos da época de Luís XIII que hoje seriam punidas. O foco explicativo do autor se centra em uma diferença radical na concepção de infância na antiga sociedade e na atual. Ainda nesse contexto de despudor contrário aos estereótipos posteriores de tabus sexuais e de inocência infantil, Ariès relata um diálogo que exprime o caráter atemporal da curiosidade em torno do sexo e das formas de raciocínio infantil: "Ele (Luis XIII, aos três anos) mostrou o pênis dizendo: - Não tem osso dentro, papai. Depois, como seu pênis se enrijecesse um pouco, acrescentou: Agora tem, de vez em quando tem" (Ariès, 1973/1981, p.107).

Por que resulta importante levar em consideração estas questões do contexto históricosocial? A sociedade atual possui algumas características muito diferentes da vienense no século XIX em que Freud formulou sua teoria e também dos anos em que Piaget escreveu suas obras e realizou suas numerosas pesquisas na Suíça e na França. Porém, haveria duas resistências que não cedem ao longo do tempo: as resistências cognitivas e pulsionais marcadas pelas estruturas assimiladoras da realidade e pelo desenvolvimento psicossexual, e as resistências sociais, evidenciadas nos tabus que ainda se constroem em torno da sexualidade, que resulta muitas vezes deformada pelos próprios adultos que transmitem as informações. Assim, o problema a ser tratado na presente pesquisa contribui para a discussão acerca da vigência das interpretações freudiana e piagetiana a partir da análise das respostas das crianças diante da pergunta da origem dos bebês, visando compreender sua gênese em seus aspectos estruturais. Portanto, os fatores sócio-históricos antes assinalados, ainda sem serem incorporados para a análise das diferenças do conteúdo das crenças infantis permitem corroborar as hipóteses anteriormente formuladas.

A vigência das teorias piagetiana e freudiana estaria no caráter irredutível dessas construções, quando se comprova que a criança desafia a razão lógica ao construir sua própria verdade, em seu próprio tempo lógico, mesmo sendo bombardeada por um excesso de tecnologia e informação (Zornig, 2008). Por fim, se é verdade que o fator social é necessário, mas não suficiente para explicar a construção do conhecimento sobre a origem dos bebês, 
pode-se sugerir que embora os conteúdos das concepções e vivências da sexualidade humana estejam influenciados pelas preferências culturais, religiosas e ideológicas e pelas possibilidades materiais dos indivíduos, existem regularidades nas formas de assimilação e nas tendências gerais da construção dos conhecimentos sobre a sexualidade.

Para entender os aspectos sócio-históricos da sexualidade, é pertinente realizar um breve percurso a respeito do conhecimento científico sobre a fecundação humana. Por um lado, ao fazê-lo se afirma a idéia piagetiana de um conhecimento científico em permanente transformação e nunca fechado de forma absoluta. Por outro lado, permite entender que não existe uma hierarquia valorativa entre os conhecimentos científicos e as crenças de caráter mítico. Sendo assim, não resulta pertinente realizar um juízo de valor sobre os conhecimentos e catalogá-los como melhores ou piores (ainda que os científicos sejam mais coordenados e objetivos). Mesmo no âmbito das atitudes mentais científicas da Medicina existiram diferentes níveis qualitativos de conhecimento porque o meio social e tecnológico exigiu e permitiu distintas construções.

No caso específico do problema do nascimento, os dados coletados no presente estudo mostram que o pré-formacionismo (noção de que o bebê existe previamente à fecundação) constitui um elemento recorrente nas explicações das crianças mais novas acerca da origem dos bebês. No contexto científico, a idéia da pré-formação também foi sustentada pela filosofia e pela medicina até meados do século XIX. Contudo, a identificação deste eixo comum entre as crenças pré-formistas da medicina e as pré-científicas das crianças não tem o objetivo de sustentar o recapitulacionismo (teoria segundo a qual a ontogênese repete a filogênese). Vale esclarecer que, embora em Freud este seja um tema controverso, pode-se afirmar que Piaget não pode ser considerado recapitulacionista, ainda que tenha encontrado numerosos elementos comuns entre o raciocínio das crianças e os de algumas teorias antigas (por exemplo, quando assinala analogias entre as respostas das crianças sobre fenômenos físicos e algumas concepções de Aristóteles).

A noção de "epistemologia genética" postulada por Piaget se caracteriza por ser "naturalista sem ser positivista", já que

põe em evidência a atividade do sujeito sem ser idealista, que se apóia também no objeto sem deixar de considerá-lo como um limite (existente, portanto, independentemente de nós, mas jamais completamente atingido) e que, sobretudo, vê no conhecimento uma elaboração contínua (Piaget, 1970a/1983, p. 5).

Piaget defende a idéia de uma ciência em constante transformação e o problema da construção do conhecimento atinge não só o sujeito, mas também o progresso das teorias 
científicas. As dificuldades não são somente da criança, a história da ciência mostra numerosos obstáculos que foram enfrentados para dar conta do problema da fecundação. A respeito disso, também Freud assinalou algumas dificuldades cognitivas para entender a complexidade da fecundação, especialmente a noção de sêmen e a função da vagina.

O problema da fecundação humana provavelmente foi um objeto de interesse enigmático desde as origens do homo sapiens. Um dos documentos sobre embriologia mais antigos de que se tem registro data de 1416 a.C., está escrito em hindu e se chama Garbba Upanisbad. Um dos fatores fundamentais para o desenvolvimento da ciência foi a liberação do pensamento das autoridades sagradas e a aplicação de um juízo crítico. Durante o renascimento, uma das figuras mais expressivas desse desligamento da religião foi Leonardo da Vinci. Estudando o corpo humano, em seus cadernos de anatomia ficaram os registros de desenhos e anotações, muito exatos para a época, dos aparelhos genitais (ovários, trompas e ligamentos). Ele conseguiu representar corretamente o crescimento embrional e fetal, assim como a posição do feto no útero (Crespo et al., 2007).

Durante o século XVIII, o mundo da ciência oscilou entre concepções pré-formistas e epigenistas (hipótese da herança como produto da combinação de óvulos e espermatozóides). No caso das pré-formistas existiam duas posições. Por um lado, os ovistas sustentavam a idéia de um humano miniaturizado existente no óvulo feminino que se desenvolvia no encontro com o espermatozóide. Por outro lado, os homunculistas ou animalculistas defendiam a idéia de que o homenzinho (homúnculo) estava agachado na cabeça do espermatozóide, enquanto a função da mãe somente era servir como incubadora do feto. Assim, o desenvolvimento intra-uterino consistia somente no aumento de tamanho (Ramos, 2004; Curtis, 1972; Rosset, 2000; Capanna, 2004; Crespo et al., 2007; Bermudo, 1978; Jagstaidt, 1987).

Entender que óvulos e espermatozóides são complementares foi uma longa empreitada científica. Anteriormente aos ovistas e homunculistas, antigas idéias embriológicas já estavam mais perto das teorias epigenistas. Como salienta Capanna (2004), muitos pensadores se ocuparam do tema: Empédocles, Demócrito, Aristóteles, Paré, Bacon, Van Helmont e Descartes já tinham defendido a participação de "duas sementes", dando assim responsabilidade a ambos os sexos. Porém, o papel de protagonista era do homem, pelo paradigma e preconceitos da época. Conforme o autor, "todas as especulações dos biólogos do século XVIII tinham servido para levar ao paradigma mecanicista até seus limites, pondo em evidencia sua inadequação para compreender processos que requeriam de outras categorias teóricas" (Capanna, 2004, p. 3). Isto sugere que o nível de construção do conhecimento vai 
depender das categorias teóricas utilizadas, o que resulta importante tanto para o âmbito científico como para o desenvolvimento cognitivo de cada criança. Para Piaget, pensar a partir de conceitos e operações também é produto de um longo processo que condiciona a qualidade da construção do conhecimento das crianças e adultos e que, portanto, resulta coerente com o tipo de pensamento que prevalece em cada etapa.

Além disso, os meios tecnológicos também possibilitam e limitam o nível de compreensão de determinados fenômenos. Ao longo da história, a filosofia e a medicina tentaram compreender a fecundação muito antes de contar com instrumentos de observação apropriados como o microscópio. No entanto, apenas recentemente com o avanço dos recursos tecnológicos foi possível que o fenômeno da fecundação pudesse ser mais bem explicado.

Até o século XVIII as duas teorias pré-formistas, o ovismo e o homunculismo, se enriqueciam com outras idéias bizarras como guerra de espermatozóides, ou a existência indefinida de um homúnculo dentro do homúnculo, sendo que cada um continha em seu interior as gerações posteriores. Para alguns ovistas, por exemplo, existia a idéia de que Eva possuía todas as gerações posteriores ao modo dos encaixes das bonecas russas. Dessa forma, cada fêmea posterior a Eva possuía um ovo a menos que a geração precedente e após 200 milhões de gerações todos os ovos acabariam e vida humana se extinguiria (Curtis, 1972).

Dentre as teorias ovistas, algumas sustentavam que o sêmen masculino funcionava como ativador e doador de moléculas nutritivas que atuavam seletivamente sobre partes ou órgãos do feto. Portanto, assim se explicava o parecido com os pais. A história demonstra que, mesmo no campo científico, o discurso religioso estava presente, influenciando as teorias construídas. No debate sobre a origem da vida, o pré-formismo exigia Deus como criador e fundamento epistemológico. Os ricos debates para o conhecimento do desenvolvimento científico mostraram uma batalha pela ciência que sempre devia ser ganha na teologia porque cada nova hipótese tinha que ser discutida nesse campo (Bermudo, 1978).

No seu estudo sobre a evolução da medicina, Oliveira (1981) assinala que se teve que esperar até o advento da teoria celular, como condição preliminar, para que a embriologia desse seus primeiros progressos em matéria de fecundação. Esse fenômeno obscuro "foi sempre algo com o poder de exaltar a imaginação do homem e suscitar as mais líricas e encantadoras fábulas" (ibid, p. 377). Aristóteles, por exemplo, é considerado o autor do primeiro livro de embriologia do Ocidente. Ele explicava que o esperma era o modelador da forma e o ovo fornecia a matéria do novo ser, sendo que o material da fêmea para a geração se originava na substância da menstruação. De modo geral, as correntes dos pré-formistas e dos 
epigenistas mantiveram suas controvérsias durante o século XVIII até que, por fim, o espermatozóide foi definido na sua natureza celular entre 1841 e 1865.

O fundamental de conhecer este percurso científico é que ele permite contar com outras ferramentas de análise para detectar, no raciocínio das crianças, certas concepções implícitas como a geração espontânea e o pré-formismo. A concepção da fecundação humana a partir de idéias pré-formistas misturadas com explicações teológicas, em contraposição à epigênese, serão retomadas na apresentação das entrevistas realizadas nesta pesquisa. 


\section{DESENVOLVIMENTO COGNITIVO E AFETIVO DA CRIANÇA NA TEORIA PIAGETIANA}

Este capítulo tem como objeto de reflexão uma seleção de conceitos e idéias elaborados por Piaget para explicar o desenvolvimento intelectual e afetivo das crianças. Por ser uma obra extensa, foi preciso realizar um recorte específico com as questões mais relevantes para entender as crenças sobre a origem dos bebês. Foram privilegiados os trabalhos do autor que estudaram o pensamento pré-operatório e operatório, e aqueles nos quais apresentou um diálogo entre a psicogênese e a psicanálise freudiana. Desse modo, priorizamos as seguintes obras: A psicanálise e sua relação com a psicologia da criança, de 1920, O pensamento simbólico e o pensamento da criança, de 1923, A representação do mundo na criança, de 1926, A formação do símbolo na criança, de 1945, As relações entre a inteligência e a afetividade no desenvolvimento da criança (curso da Sorbonne de 1954), e Inconsciente cognitivo e afetivo, de 1972, entre outros.

A tentativa de articulação sugerida nesses trabalhos por Piaget, orientada especialmente na linha de estudo da relação entre afetividade e inteligência, constitui a diretriz da presente pesquisa. Com esse propósito, parte-se de algumas considerações gerais sobre a concepção de sujeito próprio da psicogênese piagetiana, para logo após dar lugar às características mais significativas para este estudo dos períodos do desenvolvimento pré-operatório e operatório concreto, nas suas dimensões cognitiva e afetiva.

Levando em consideração os aspectos do pensamento e da afetividade previamente levantados, é discutida e justificada a escolha do termo crenças entre outros termos possíveis como conhecimentos, idéias, representações, mitos ou teorias. A noção de crença implica um ponto de resistência ao fator social, por exemplo, à educação. Por sua vez, admite entender com maior fluidez a perspectiva piagetiana acerca da progressão genética do problema do nascimento, especialmente a partir dos estágios do artificialismo propostos pelo autor. Aqui, a pesquisa de Kohlberg (1966) sobre as diferenças sexuais, inspirada na psicogênese piagetiana, acrescenta possibilidades de diálogo com a noção freudiana de teorias sexuais infantis e enriquece a análise dos dados coletados acerca das diferenças sexuais.

\subsection{A concepção de sujeito na ótica piagetiana}

De acordo com a perspectiva piagetiana, todo individuo constitui um sujeito epistêmico, ou seja, um sujeito conhecedor e assimilador de objetos, porque não existe sujeito humano 
que não tente dar explicações e respostas diante dos mistérios e problemas que emergem da infinita diversidade de fenômenos do mundo físico, moral, social e afetivo. Nessa linha, conhecer é uma questão de adaptação e de sobrevivência. No livro Introdução ao Método Clínico, Juan Delval (2002) assinala que diversos achados arqueológicos revelam a necessidade dos homens de buscar explicações que dessem sentido ao que ocorria em sua volta. Essas explicações permitem estabelecer regularidades para os fenômenos naturais e os assuntos relacionados com a sua existência e evitar a angústia do aleatório e do acaso. Desde a antiguidade, os mitos de diferentes culturas sobre a origem dos animais, dos homens e da natureza são prova disso.

Ao longo do seu desenvolvimento ontogenético o ser humano é interpelado a construir conhecimentos porque o meio apresenta constantes problemas que precisam ser resolvidos. Mas cada sujeito que aparece no mundo não constrói tudo do zero. A história, característica humana diferencial em comparação com os outros animais, permite que a interação com o entorno natural e social se manifeste como resultado da dialética transmissão-construção. Este processo resulta indispensável para o desenvolvimento humano.

A concepção de sujeito pressuposto em uma teoria determina a escolha do procedimento para a coleta de dados, o tipo de análise e as categorias que se estabelecem para organizá-los. Piaget (1926/2005, p. 27) entende que "a história do desenvolvimento intelectual da criança é em grande parte a história da socialização progressiva de um pensamento individual” e que, como já foi mencionado, não se pode desconhecer as duas partes que conformam o seu pensamento: uma original da criança e outra de influência adulta. Essa noção de "influência" é diferente da "determinação" do meio que levaria à concepção de um sujeito reprodutor, tipo tábula rasa, que acumula informação e deixa intacto tudo o que lhe é transmitido do meio social. A dialética piagetiana mostra sua ênfase nessa interação entre o sujeito e o objeto que se dá no "entre" eles, e não é determinada por nenhum dos dois pólos. Há socialização, mas também há atividade do sujeito. Para entender essa concepção de sujeito é conveniente lembrar a noção piagetiana de construção. De Souza (2004a) explica que para Piaget se constrói:

o sujeito, de um lado, e o objeto, de outro, e ambos, simultaneamente. Da parte do sujeito, o autor centralizou-se nas estruturas da inteligência como forma de organização da atividade, as quais variam no decorrer da vida do indivíduo. Da parte do objeto, referiu-se às crenças, noções e conceitos que configuram o real, o mundo, o outro. (De Souza 2004a, p. 38)

Se o sujeito e o objeto se constroem mutuamente na interação, é possível indicar que a concepção de Piaget é a de um sujeito que recria, constrói e reconstrói os objetos físicos e sociais que recebe do meio e se recria a si mesmo na procura gradativa de melhores 
equilíbrios, ou seja, de melhores adaptações. Piaget é enfático quando afirma que a criança não pode copiar tudo, em primeiro lugar porque sua imitação é seletiva, e em segundo lugar porque ela deforma e recria aquilo que parece copiado, porque é a ação que funciona como mediadora em suas interações com o mundo. Além disso, o sujeito ativo organiza seu pensamento a partir de uma estrutura cognitiva que se desenvolve não somente como consequiência da pressão exterior. Para entender esses processos, Piaget cita a analogia de Stern de uma "química mental" própria da criança que lhe faz 'digerir' o que toma do meio (1926/2005, p. 29).

Porém, é preciso ressaltar que a criança não está em uma ilha deserta, mas em um meio social que é fator necessário, mas não suficiente para seu desenvolvimento. Piaget (ibid, pp. 28-30) define a criança como um ser "cuja principal atividade é a adaptação e que busca adaptar-se tanto ao mundo adulto que a cerca como à própria natureza". Esse mundo adulto que exige adaptação ativa implica, entre várias questões, uma linguagem que deverá ser aprendida e que, na perspectiva piagetiana, resulta em uma "realidade opaca" para a criança, que organiza seu pensamento verbal a partir dos "esquemas de digestão mental". Assim, esta assimila a realidade de acordo com sua estrutura mental, a qual muitas vezes provoca "deformações" dos sentidos consensuados.

O rigor das pesquisas de Piaget resulta em uma concepção de sujeito original e solidamente fundamentada. O "fator social" é necessário, mas não suficiente para explicar, por exemplo, a passagem da inteligência sensório-motora à das representações. A especificidade da sua concepção de sujeito ativo continua em destaque e longe de ambigüidades. Nas palavras do próprio autor:

(...) a Psicologia não poderia contentar-se com um salto da Neurologia para a Sociologia. O que se tem de encontrar não é apenas a explicação da 'representação' em geral, mas uma explicação suscetível de penetrar no próprio pormenor dos mecanismos representativos (Piaget, 1945/1975, p. 277).

Por que Piaget, formado em Biologia e Filosofia, se interessou pelos mecanismos representativos do sujeito? Uma resposta pode ser achada na obra Lógica e conhecimento científico (1967/1980), na qual o autor explica que, independentemente do método epistemológico que se utilize, sempre é preciso recorrer à psicogênese porque além da validade formal, a epistemologia se ocupa das relações de conhecimento que se estabelecem entre o sujeito e os objetos. Por esse motivo não é possível deixar de lado os problemas relativos ao sujeito que conhece o objeto pela sua própria experiência. É fundamental entender como ele organiza a experiência e apelar aos processos psicológicos que comportam uma dimensão genética, os quais resultam significativos para a epistemologia. Para fugir dos 
recursos especulativos é necessário evitar consultar apenas à consciência do sujeito (via introspecção), porque, em linhas gerais, o sujeito nada sabe das estruturas gerais do pensamento. A solução oferecida por Piaget é a análise genética do desenvolvimento do pensamento do sujeito epistêmico.

A psicogênese piagetiana estuda e postula quatro formas de organizar o mundo e a si mesmo a partir de categorias (objeto, tempo, espaço e causalidade), que são construídas progressivamente. Essas quatro formas, na perspectiva do desenvolvimento de crianças e adolescentes são: o período da inteligência sensório-motora (primeiros 24 meses de vida), o período do pensamento pré-operatório (entre 2 e 7/8 anos), o período das operações concretas (entre 7/8 e 11/12 anos) e o período das operações formais (de 11/12 anos em diante). As idades são sempre aproximadas, sendo invariável, porém, a sua ordem de sucessão. Isso é muito importante porque há meios e domínios que não exigem ir além de assimilações préoperatórias ou operatórias concretas.

Em linhas gerais, a psicogênese das estruturas mentais do pensamento constitui um processo de transformação de um estado de egocentrismo radical a uma descentração relativa. A sucessão das estruturas do pensamento é integrativa e pode ser pensada como um espiral, porque a passagem de uma forma de assimilação do mundo a outra não significa a desaparição da primeira. Cada estrutura prolonga a precedente e a reconstrói em um novo plano para incorporá-la em um nível superior de organização mental. Assim, “as estruturas de conjunto são integrativas e não se substituem umas a outras: cada uma resulta da precedente, integrando-a como estrutura subordinada, e prepara a seguinte, integrando-se antes e depois dela" (Piaget \& Inhelder, 1966/1972, p. 152). Por um lado, em relação ao sujeito, a descentração é entendida como a capacidade de discriminar e coordenar, e também como função da construção de esquemas de ação. Em cada estágio o sujeito apresenta um nível de descentração superior ao precedente, mas que constitui ao mesmo tempo um nível de egocentrismo em relação ao posterior (Benbenaste, 2005). Por outro lado, a noção de objeto piagetiana é coerente com essa idéia de sujeito, que progressivamente ganha em objetividade ainda que sempre esteja interpretando os objetos. Nesse sentido, Piaget assim caracteriza o objeto:

(...) o objeto existe. Mas não se descobre suas propriedades mais que por aproximações sucessivas. É o contrário do idealismo. Aproxima-se dele sem parar, mas não o atingimos porque para atingi-lo se necessitariam sem dúvida uma infinidade de propriedades, grande número das quais nos escapam (Piaget apud Bringuier 1977/2004, p. 114). 
A psicogênese piagetiana explica os níveis diversos dessas interpretações do objeto a partir de períodos diferenciados por formas de organização mental que gradativamente resultam mais objetivas. A seguir, serão apresentadas algumas características dos períodos do desenvolvimento cognitivo correspondentes às formas de organização mental dos participantes da presente pesquisa.

\subsection{Características do período pré-operatório}

$\mathrm{O}$ principal avanço do período pré-operatório em relação à inteligência prática do período sensório motor é a aparição da função semiótica. Essa nova capacidade permite à criança evocar uma situação ausente. Porém, o pensamento permanece pré-operatório no sentido de que as operações ainda não são atingidas pela impossibilidade de alcançar a reversibilidade lógica e as estruturas de conjunto adequadas. O pensamento deste período é dominado pelo aspecto figurativo das representações (Piaget, 1972/1983).

Durante este período de inteligência representativa, o raciocínio da criança é transdutivo e intuitivo porque vai do particular ao particular e procede por analogias imediatas. $\mathrm{O}$ pensamento intuitivo estabelece uma transição entre os esquemas imagísticos e préconceituais (processamento da informação por participação direta e sem classes gerais) e os posteriores conceitos operatórios. Constitui um pensamento artificialista porque manifesta uma assimilação contínua dos processos naturais à atividade humana. Nesse período a criança entende que todas as coisas são produto da fabricação humana: o homem é o chefe e a razão de todas as coisas. Assim, a participação antropocêntrica constitui o núcleo do artificialismo. O pensamento pré-operatório se caracteriza pela tendência a permanecer individual, ou seja, o símbolo faz o lugar do signo. Diferentemente da linguagem inter-individual que está constituída por signos arbitrários e convencionais, a criança pequena, por estar muito menos socializada necessita de outro sistema de significantes, mais individuais e mais motivados: esses são os símbolos. Os paradigmas do simbolismo individual são o jogo, a imitação, os símbolos oníricos e a imaginação em geral (Piaget 1964/1975). Assim, os significados constituem as experiências íntimas do sujeito. Conseqüientemente, o pensamento intuitivo é considerado também como egocêntrico, "não no sentido de uma hipertrofia do eu, senão no de uma centração no próprio ponto de vista”. É a descentração o que lhe permitirá atingir graus de objetividade porque "é sobretudo com os demais quando estamos obrigados a não nos contradizer" (ibid, p. 184). 
Nesse período a criança também se centra mais nos estados, e especialmente nos estados finais, que nos processos (ibid, p. 114-5). Portanto, para Piaget, as estruturas pré-operatórias são intermediárias entre o simbolismo puro e o pensamento racional socializado. Cabe ressaltar que as analogias entre o pensamento simbólico e o pensamento egocêntrico são de estrutura e não de conteúdos.

A estrutura pré-conceitual da organização do pensamento é próxima do esquema imagístico porque o sujeito ignora ao mesmo tempo a generalidade (inclusões hierárquicas) e a identidade individual (permanência do objeto idêntico fora do campo de ação próximo) próprias aos conceitos e aos seus elementos. A acomodação desse período é ainda insuficiente para atingir a generalidade do esquema conceitual. Por sua dificuldade de generalizar, a criança encontra obstáculos para utilizar conceitos propriamente ditos. Ao mesmo tempo, seu pensamento egocêntrico a leva a compreender tudo a partir dela mesma (Piaget, 1945/1975).

A função semiótica que se inaugura nesse período se expressa em cinco tipos de condutas: a imitação diferida, o jogo simbólico, a imagem mental, o desenho e a linguagem. $\mathrm{O}$ pensamento pré-lógico da criança se evidencia nessas condutas pela ausência de limites precisos entre o Eu e o mundo das representações subjetivas, e o não-Eu e as representações exteriores e objetivas. Assim, o Eu se identifica e se projeta, quebrando as barreiras que o separam do mundo objetivo. Por não ter tomado total consciência da existência dos outros, o pensamento infantil ainda não tem consciência dos limites do Eu, que será conquistada graças ao progressivo processo contínuo e construtivo de socialização (Piaget, 1923/1994).

$\mathrm{Na}$ ótica piagetiana, o processo de socialização da criança é muito abrangente: "a socialização não é uma adição de conhecimentos análogos aos que já possui, mas uma espécie de descentralização geral, uma revisão do seu sistema de perspectivas e de avaliações" (Piaget, 1923b/1999, p. 79). Em outras palavras, a criança trocará de sistemas de interpretação e o que era absoluto será, então, um ponto de vista em relação a outros. A socialização será um fator de amenização do egocentrismo, entendido como uma centralização do pensamento, ou seja, como "uma inocência de espírito no sentido de ausência de toda relatividade intelectual e de sistema relacional de referência" (ibidem).

Em relação a essa ausência de relatividade, Piaget argumenta que aproximadamente aos três anos, a criança atravessa uma "crise de oposição" que pode ser traduzida na elaboração de jogos simbólicos. Nessa etapa se evidencia uma necessidade de afirmação e independência junto a rivalidades de tipo edipiano. Para Piaget, o jogo simbólico se destaca, então, como uma atividade cuja motivação não é a adaptação ao real, mas uma assimilação do real ao Eu, transformando esse real segundo as necessidades da criança. O jogo como "liquidação de 
conflitos" se apóia também em conflitos inconscientes como: interesses sexuais, defesas contra a angústia, fobias, agressividade etc. (Piaget, 1966/1972).

$\mathrm{Na}$ obra $A$ representação do mundo na criança, a partir de pesquisas baseadas em entrevistas individuais e semidirigidas, Piaget (1926/2005) caracteriza o pensamento préoperatório sob distintas formas e tendências: animismo, participação, magia, realismo, intencionalismo, artificialismo, pré-causalidade e egocentrismo. Estas características foram consideradas na análise dos dados coletados. Constituem conceitos complexos porque na maioria das vezes se expressam de maneira simultânea, em uma estrutura de conjunto definida por leis de totalidade. Porém, serão definidos brevemente de maneira individual.

O pensamento animista consiste na tendência da criança de dar vida e consciência aos seres inanimados. O animismo é produto de participações que a criança sente existir entre ela e seus pais desde a origem e também se constitui como conseqüência do realismo egocêntrico. A natureza é obediente a todas as pessoas e especialmente a seus pais. Dado que a criança ainda não descobriu a multiplicidade de perspectivas, ela se mantém encerrada na sua, como se esta fosse a única possível. Portanto, nesse período ela afirma sem provas porque não sente a necessidade de convencer. Ao animismo se somam a participação e a magia. A participação é a relação que a criança crê perceber entre dois seres ou fenômenos que considera parcialmente idênticos ou com uma relação de influência, ainda que não tenham ligação espacial ou conexão causal inteligível (Piaget, 1926/2005). A magia nasce dessa confusão entre o signo e a causa e é conseqüência do realismo do signo. No caso da magia por participação entre o pensamento e as coisas, um exemplo seria o rito de pensar em alguma coisa para que um evento se produza ou não. A noção é similar à onipotência do pensamento assinalada por Freud porque a atividade própria é considerada como todo-poderosa. No caso da magia por gestos, um exemplo claro é conseguir andar na calçada sem tocar as linhas intersticiais, o que é sinal de que algo desejável vai acontecer. O gesto simbólico se reveste de eficácia ao modo das superstições.

O realismo encerra várias questões. Por um lado, um sentimento de participação entre o mundo e o Eu. Isso significa que existe uma projeção de ligações mentais nas coisas: todo signo é vinculado às próprias coisas que designa e pode se tornar causa. Como exemplo disso, os conceitos e as palavras são "emanações" das coisas, sem considerar o caráter arbitrário e consensual dos nomes. Por outro lado, o realismo implica uma indiferenciação entre relações lógicas e relações causais porque o espírito realista ignora a subjetividade dos pontos de vista. Para Piaget, todo realismo se prolonga em magia e, mesmo no adulto, permanece algo de realismo na imitação involuntária, no temor e nos estados de inquietação ou de desejo de 
alguma coisa. Por exemplo, fazer uma caminhada antes de uma conferência para que seja bem-sucedida, ou deixar de pensar em uma fatalidade para assim impedir que ocorra de verdade (Piaget 1926/2005, pp. 133-141).

O pensamento da criança também se elabora a partir da premissa do intencionalismo, intimamente relacionada com a noção de finalismo. Para Piaget, do intencionalismo à atribuição de consciência às coisas (animismo) há uma passagem imperceptível. $\mathrm{O}$ intencionalismo "se apóia no postulado de que tudo, na natureza, tem uma razão de ser na forma de um officium que cada corpo é chamado a exercer de acordo com o caráter que lhe é próprio" (ibid, p. 288). Assim, o intencionalismo supõe o animismo porque cada ser tem que ter discernimento do seu papel na organização social do mundo. Social porque o artificialismo implica que tudo é feito para e pelos homens; por exemplo, o sol nos segue "para nos aquecer".

Alem do papel que cumprem, todos os corpos são subordinados a ordens e chefes humanos. Todos os objetos, inclusive os da natureza, respondem a um sistema de pensamento artificialista que entende que são "feitos para o homem". Essa atitude mental dá nascimento à formula é "feito pelo homem". A passagem do "feito para" ao "feito pelo", para Piaget (1926/2005), "explica-se, com efeito, facilmente se nos recordamos que a criança, que tem a existência inteira organizada pelos pais, considera qualquer coisa que 'é feita para' ela como ‘feita por' seu pai ou sua mãe” (p. 286-287). Dessa forma, a participação antropocêntrica seria o núcleo do artificialismo espontâneo que mergulha profundamente na vida afetiva e intelectual da criança. $\mathrm{O}$ artificialismo existe como orientação do espírito e está profundamente ligada ao finalismo e à pré-causalidade infantil, sendo mais implícito que sistemático. Outra tendência deste período é a pré-causalidade que consiste em procurar a causa de um fenômeno na intenção e não no como de sua realização. Assim, a causa (física) se confunde com intenção (psíquica).

O caráter egocêntrico do pensamento pré-operatório se estrutura na dificuldade de descentração do próprio ponto de vista e de discernimento do que vem da própria criança ou dos outros em relação a seus conhecimentos. Este egocentrismo é um conceito fundamental para entender o desenvolvimento cognitivo e afetivo da criança. Piaget (1923b/1999) afirma que há um período de linguagem egocêntrica que passa, dos 3 aos 6 anos, por um estado "semi-estacionário" durante o qual diminui gradualmente. Esta amenização do egocentrismo se produz por duas vias de socialização: a dos adultos e a dos seus semelhantes. Afetiva e cognitivamente, o egocentrismo é um fenômeno ligado ao vinculo da criança com seus pais, 
considerados como um "alter-ego" com vontade todo-poderosa e de inteligência superior. Nas palavras de Piaget:

o adulto é simultaneamente muito superior e próximo da criança. Domina tudo, mas, ao mesmo tempo, penetra na intimidade de cada desejo ou pensamento (...) tudo o que a criança faz é partilhado com sua mãe, sem que nenhuma fronteira separe, do seu ponto de vista, seu próprio Eu desse Eu superior (1923b/1999, p. 67).

No livro O Juízo moral na criança, de 1932, Piaget afirma que o egocentrismo, longe de ser um comportamento anti-social, é só pré-social em relação à cooperação, que fará desaparecer a mística da autoridade. Piaget postula que

a medida que a criança cresce, seu respeito pela superioridade adulta diminui, ou pelo menos muda de caráter. $\mathrm{O}$ adulto deixa de representar a Verdade indiscutida, e mesmo indiscutível, e a interrogação transforma-se em discussão (1923b/1999, p. 68).

A citação acima mostra a importância do vinculo filial para o desenvolvimento de uma autonomia intelectual. Somado a isso, a criança de pensamento pré-operatório ainda não diferencia entre uma invenção e a reminiscência, entre o antigo e o novo, entre o que provém de si, da sua fantasia individual e das regras impostas do alto. O egocentrismo intelectual (na tomada de consciência da regra) é sempre mais resistente que o egocentrismo em ato (a ação na prática das regras). Portanto, o realismo moral que dirige o pensamento pré-operatório resulta, por um lado, da confusão entre o subjetivo e o objetivo e, por outro, da coação intelectual do adulto.

Durante esse período, os mecanismos do pensamento infantil descritos anteriormente se exprimem na forma de certezas que não são postas em dúvida pelas crianças pequenas. Ao não serem problematizados, poucos traços de dúvida direta ou indireta emergem nas explicações das crianças, enquanto que o animismo e o artificialismo se complementam e consolidam mutuamente como atitudes de espírito. A respeito das estruturas pré-operatórias, pode-se falar de um "pensamento motor" mais que conceitual considerando que a tomada de consciência é um processo complexo de reconstrução que dá conta das defasagens do desenvolvimento (Piaget, 1926/2005). Assim, as crenças são criações egocêntricas nas quais se encontram fantasias que, ainda que possam ser influenciadas pelas explicações dos adultos, sempre são assimilações de conteúdos à mentalidade infantil. Por isso, o pensamento deste período consiste em um começo ou forma primitiva do pensamento lógico.

De Souza afirma que a proposta piagetiana para pensar a afetividade no desenvolvimento da criança assinala "relações de correspondência entre a evolução cognitiva e a afetiva, superando as formulações causais e de complementaridade" (2011, p. 252). A autora explica que essa correspondência constante entre aspectos afetivos e intelectuais, 
presentes em qualquer conduta e em cada fase do desenvolvimento, significa entender que seus desenvolvimentos não são apenas paralelos, mas interdependentes. Ainda que possuam naturezas diferentes, a inteligência (com seu papel estrutural) e a afetividade (como energética) são adaptação contínua e pólos indissociáveis na conduta. Para De Souza (2011), em uma perspectiva piagetiana, o método das entrevistas constitui um procedimento para indagar os modos de reflexão da criança, a sua valorização (afetiva) e organização de seus interesses.

O foco da preocupação piagetiana consiste em achar o tema ou elemento comum das respostas para pensar a progressão genética do pensamento humano a partir das suas formas. O encontro da tendência espontânea da criança com as informações adultas de diversas fontes e a variação da valorização dos elementos de conhecimento segundo a idade são dois pressupostos a considerar no momento de organizar e analisar as respostas coletadas nas entrevistas. Segundo Piaget (1933/1994) os pressupostos do paralelismo entre afetividade e pensamento são os seguintes: 1) ambos têm uma historia, ou seja, evoluem na sua estrutura e não só nos seus conteúdos 2) os complexos afetivos correspondem ao desenvolvimento do pensamento 3) tanto o pensamento como os sentimentos podem ser anárquicos ou disciplinados. O pensamento é disciplinado pela vida social.

A partir desses pressupostos, uma importante base de análise resulta da comparação entre estruturas cognitivas e sistemas afetivos, aspectos considerados como simultâneos no desenvolvimento e que permitem estabelecer correspondências. Essas correspondências foram expressas para os três estágios que se resumem no quadro abaixo (parte B do quadro original), e que inclui desde o período pré-operatório do pensamento até o operatório formal. Para os objetivos da presente pesquisa, só aprofundaremos essas considerações piagetianas a respeito dos períodos IV e $\mathrm{V}$, desconsiderando assim os estágios da inteligência sensório-motora (parte A do quadro) e do pensamento operatório formal (estágio VI). ${ }^{6}$

\footnotetext{
${ }^{6}$ A totalidade do quadro foi apresentada por Piaget em um curso sobre Inteligência e Afetividade, ministrado na Sorbonne, entre 1953 e 1954. O quadro apresenta dois grandes períodos do desenvolvimento humano correspondentes às duas partes do quadro: parte A- Inteligência sensório-motora (estágios I, II e III); parte BInteligência verbal (estágios IV, V, VI). Só para evitar mais distorções, deixamos aqui a totalidade da parte B, portanto foi incluído o estágio VI das operações formais (Piaget, 1953-1954/2005, pp. 31-32).
} 
PARALELISMO ENTRE OS ESTÁGIOS DO DESENVOLVIMENTO INTELECTUAL E AFETIVO (PARTE B)

\begin{tabular}{|c|c|c|}
\hline ESTÁGIOS & $\begin{array}{c}\text { INTELIGÊNCIA VERBAL } \\
\text { (CONCEITUAL = SOCIALIZADA) }\end{array}$ & $\begin{array}{l}\text { SENTIMENTOS INTERINDIVIDUAIS } \\
\text { (INTERCÂMBIOS AFETIVOS ENTRE PESSOAS) }\end{array}$ \\
\hline IV & $\begin{array}{c}\text { Representações pré-operatórias } \\
\text { (interiorização da ação em um pensamento } \\
\text { ainda não reversível) }\end{array}$ & $\begin{array}{l}\text { Afetos intuitivos } \\
\text { (sentimentos sociais elementares, aparição } \\
\text { dos primeiros sentimentos morais). }\end{array}$ \\
\hline $\mathbf{V}$ & $\begin{array}{l}\text { Operações concretas: } \\
\text { (de 7-8 anos a 10-11 anos) } \\
\text { (Operações elementares de classes e de } \\
\text { relações = pensamento não formal) }\end{array}$ & $\begin{array}{c}\text { Afetos normativos } \\
\text { Aparição de sentimentos morais autônomos, } \\
\text { com intervenção da vontade (o justo e o } \\
\text { injusto não dependem já da obediência a uma } \\
\text { regra). }\end{array}$ \\
\hline VI & $\begin{array}{l}\text { Operações formais } \\
\text { (começam aos } 11-12 \text { anos, mas não se realizam } \\
\text { plenamente até os } 14-15 \text { anos) } \\
\text { Lógica das proposições liberada dos conteúdos. }\end{array}$ & $\begin{array}{c}\text { Sentimentos “ideológicos" } \\
\text {-os sentimentos interindividuais se } \\
\text { complementam com sentimentos que tem por } \\
\text { objetivos ideais coletivos. } \\
\text {-elaboração paralela da personalidade: o } \\
\text { individuo se designa um papel e umas mentas } \\
\text { na vida social. }\end{array}$ \\
\hline
\end{tabular}

Fonte: Piaget (1953-54/2005).

Esse quadro dos estágios do desenvolvimento intelectual e afetivo deve ser entendido a partir da metáfora piagetiana do motor do carro e da gasolina. Em 1953, Piaget diz que a inteligência, por ser estrutura, seria como o motor do carro que depende da gasolina (afeto) para funcionar. A afetividade cumpre o papel de função energética, mas ela não modifica a estrutura, assim como a gasolina não modifica o motor do carro. Ainda que a afetividade possa causar acelerações ou atrasos no desenvolvimento intelectual, não gera estruturas nem modifica seu funcionamento. Assim, os estágios da inteligência e dos afetos presentes no quadro devem ser entendidos em suas relações funcionais na conduta do sujeito (Piaget, 1953-54/2005).

No quadro, o período pré-operatório da inteligência corresponde ao estágio IV, chamado de afetos intuitivos. No plano afetivo, a representação e a linguagem dão lugar a sentimentos mais estáveis e duradouros que, ao se tornarem representativos, serão socializados tal como a inteligência. As três novidades dos afetos intuitivos assinalados no quadro comparativo são:

o desenvolvimento de sentimentos interindividuais (afetos, simpatias e antipatias) ligados a socialização das ações, a aparição dos sentimentos morais intuitivos surgidos das relações entre adultos e crianças, e as regulações de interesses e valores, relacionadas com as do pensamento intuitivo em geral (Piaget, 1964/1975, p. 55). 
Assim, desenvolvem-se sentimentos interindividuais e morais, e estes últimos, ao se conservarem, darão lugar progressivamente aos sentimentos normativos e a escalas de valores. Em que consistem os sentimentos interindividuais característicos desse período? Piaget (1953-54/2005) define a simpatia e a antipatia como as formas mais simples de sentimentos interindividuais. A simpatia supõe correspondência entre escalas de valores dos interlocutores e um intercâmbio recíproco que não seja deficitário. A introdução da conservação permitirá esboçar os primeiros sentimentos normativos com um esquema análogo ao das regulações da inteligência.

Em relação ao período sensório-motor, os interesses se diferenciam e se diversificam. Para Piaget, um objeto só resulta interessante se responde a uma necessidade. O interesse é a orientação de todo ato de assimilação mental e constitui, por um lado, um regulador da energia, e por outro, um sistema de valores. Aos interesses e valores relativos à atividade estão ligados os sentimentos de autovalorização: sentimentos de inferioridade e superioridade. Pouco a pouco o indivíduo vai formando um juízo de si mesmo "que pode ter grandes repercussões em todo o desenvolvimento" (Piaget, 1964, pp. 56-57).

A autovalorização é definida por Piaget (1953-54) como a aplicação sobre o próprio sujeito do esquema da simpatia e das condutas socialmente aceitas. O assunto é complexo porque a aprovação externa seria uma das mais profundas necessidades do ser humano. A autovalorização intervém especialmente nesse quarto estágio, mas com freqüência independentemente das relações sociais, porque a criança pode ter uma autovalorização superior ou inferior em relação à que os outros fazem dela. Nesse ponto se pode assinalar uma convergência com a constituição do Superego ${ }^{7}$, posto que Freud (1938/1974) ressalta que a sua severidade nem sempre corresponde a figuras parentais muito autoritárias.

No plano da moral, a criança se sente subordinada aos adultos, principalmente a seus pais, que considera grandes e fortes, o que leva a um respeito unilateral, com núcleos concretos de obediência e "submissão inconsciente intelectual e afetiva devida à pressão espiritual exercida pelo adulto" (Piaget, 1964/1975, p. 35). Retomando os trabalhos de Bovet, Piaget afirma que o respeito unilateral é o primeiro sentimento que caracteriza a moral da obediência e que anuncia os sentimentos normativos. Esses últimos somente surgirão no período das operações concretas com a moral autônoma e o respeito mútuo. Os sentimentos do período pré-operatório em relação à moral são seminormativos, porque no campo dos

\footnotetext{
${ }^{7}$ Ainda que Freud não tenha usado os termos em latim Ego, Superego e $I d$, mas Eu, Supereu e Isso, neste trabalho será mantida a terminologia oriunda da tradução inglesa por ser mais freqüente na tradição acadêmica brasileira.
} 
sentimentos se encontram condutas análogas às formas rudimentares de operação que estão ligadas à configuração perceptiva. Neste estágio não há ainda autonomia nem generalização das normas que são válidas em condições particulares. Há realismo moral porque a consigna é ligada a situações representadas e porque a norma se sente como exterior e existente em si (Piaget, 1953-54/2005). A moral deste período resulta heterônoma porque ainda depende da vontade externa, ou seja, dos pais e seres respeitados. Essa moral da obediência responde a uma valoração unilateral: o respeito composto de amor e temor, que marca a desigualdade. As ordens e consignas são obrigatórias e engendram o sentimento de dever (Piaget, 1964/1975, pp. 58-59).

Todos os aspectos afetivos apresentados por Piaget durante 1953-54 no curso ministrado na Sorbonne podem ser contextualizados e relacionados com as características já mencionadas do pensamento pré-operatório, entendido como intermediário entre o pensamento simbólico e o lógico porque é egocêntrico. Por fim, nas palavras de De Souza, a concepção piagetiana do desenvolvimento afetivo consiste em:

uma evolução paralela à da inteligência e que segue os mesmos passos e movimentos evolutivos. A afetividade não pode, assim, interferir nas construções cognitivas, sendo responsável apenas pelo ritmo dessas construções. (...) não se pode dizer que Piaget desconsiderasse a presença dos aspectos afetivos (...) (De Souza, 2004a, p.66).

Em linhas gerais, se noções como as classificações, seriações e correspondências termo a termo, entre outras, são reconstruídas gradualmente no plano da representação durante o período pré-operatório, só serão consolidadas na sua perspectiva lógica (e já não perceptiva), no período das operações concretas. Em correspondência, na dimensão afetiva, a passagem do descentração física atingida no período sensório-motor à descentração subjetiva, só será atingida no próximo período, com a diminuição do egocentrismo epistêmico próprio do pensamento intuitivo e artificialista. Essas características da inteligência e da afetividade (estágio V do quadro) serão abordadas no item seguinte.

\subsection{Características do período operatório concreto}

Piaget (1964/1975) afirma que durante o período operatório concreto, que em muitas culturas geralmente coincide com o principio da escolaridade, a vida psíquica (inteligência e afetividade), as relações sociais e a atividade individual tomam novas formas de organização que consolidam as construções do período anterior em um equilíbrio mais estável que inaugura novas construções. Entre sete e onze anos, aproximadamente, a linguagem 
egocêntrica vai desaparecendo quase por inteiro, exprimindo agora a necessidade da conexão entre ideais e justificações lógicas. Em vez de ter condutas impulsivas próprias do egocentrismo intelectual, a criança pensa melhor antes de atuar e vai conquistando a atividade de reflexão.

A libertação progressiva do egocentrismo social e intelectual a leva a ser capaz de novas coordenações importantes tanto para a inteligência como para a afetividade. A criança começa a construir a lógica, a partir de um sistema de relações que permite a coordenação de pontos de vista. O sistema de relações sociais e individuais "engendra uma moral da cooperação e a autonomia pessoal, por oposição à moral intuitiva de heteronomia própria dos pequenos" (ibid, p. 65). A operação é o instrumento mental que permite essa dupla coordenação lógica e moral, enquanto que a vontade será o instrumento do plano afetivo. Ambas resultam da conversão do egocentrismo. Assim, a criança estará interessada em jogos de regras e outras atividades que implicam atitudes sociais e comportamentos coletivos regidos pela cooperação (Piaget, 1964/1975, pp. 61-63).

A grande conquista deste período são as operações, definidas por Piaget como ações interiorizadas e reversíveis. As operações se coordenam em sistemas fechados ou estruturas (classificação, seriação, etc.) que supõem a construção de invariáveis (Piaget, 1953-54/2005). Da ação à operação há três conquistas que se constroem ao longo dos cinco ou seis anos que dura o período pré-operatório já comentado anteriormente. Essas conquistas são progressivas porque há obstáculos a superar, sendo que a ação não se prolonga diretamente em representação. O primeiro obstáculo é a necessidade de reconstruir no novo plano da representação o que já tinha sido adquirido no plano da ação. O segundo consiste na realização de um trabalho de descentração que foi atingido no plano da ação, mas que logo abrange um universo muito mais extenso e complexo. Por último essa descentração será de maneira indissociável necessária no universo social ou interindividual.

O meio social é bem importante para entender essa passagem ao pensamento operatório. Nas palavras de Piaget: "Aos 7-8 anos, aproximadamente (mas, repetimos, essas idades médias dependem dos meios sociais e escolares), a criança atinge, por meio de interessantes fases de transição (...), a constituição de uma lógica e de estruturas operatórias que chamaremos concretas" (Piaget, 1964/1975, p. 177).

As operações deste período são concretas, por oposição ao caráter formal de hipóteses sem objetos, porque constituem formas inseparáveis de conteúdos. Durante este período as operações permanecem concretas porque são limitadas ao domínio da manipulação dos objetos e do universo do real (e não do possível) no plano verbal. O pensamento operatório é 
capaz de considerar transformações reversíveis, que são sempre relativas a uma invariável. O que é uma invariável? É uma noção ou um esquema de conservação. Por exemplo, o esquema de objeto permanente é a invariável do grupo prático dos deslocamentos. Logo após, a criança descobre a conservação da substância entre 7 e 8 anos, do peso entre 9 e 10, e do volume aos 11 ou 12 anos aproximadamente. Se as reações do período pré-operatório eram centradas nas configurações percebidas ou imaginadas, no operatório estão fundadas na identidade e a reversibilidade por inversão ou por reciprocidade (Piaget \& Inhelder, 1966/1972, pp. 97-102).

Essa conquista acarreta uma alteração qualitativa essencial, mas sem ser um começo absoluto porque no curso do desenvolvimento, para Piaget (1970a/1983), o que é novo procede de diferenciações progressivas ou coordenações graduais. A pré-causalidade sensório-motora precede à pré-causalidade representativa, que é assimilação à ação própria em sua orientação egocêntrica. No nível das operações concretas ela se transforma em uma causalidade racional por assimilação às operações que são coordenações gerais das ações. Um exemplo citado por Piaget é o atomismo infantil, pesquisado na prova do açúcar dissolvido em água. Até os 7 anos, aproximadamente, a criança pensa que o açúcar desaparece, mas progressivamente entende que se conserva. Outra conquista importante deste período são as formas operatórias de causalidade, que são produto de um longo processo porque o real resiste à dedução e tem sempre uma parte maior ou menor de aleatório. Assim, a noção de probabilidade se constrói devagar, e só será concluída depois dos 11 ou 12 anos (Piaget, 1966/1972, pp. 113-115).

Como foi apresentado anteriormente no quadro do paralelismo entre o desenvolvimento da inteligência e da afetividade elaborado por Piaget (cf. item 2.2), na perspectiva afetiva, este período das operações concretas é correspondente ao estágio dos afetos normativos que incluem a vontade e os sentimentos morais autônomos. As transformações afetivas deste estágio são correspondentes às cognitivas. Os valores constituem progressivamente sistemas coordenados e reversíveis. Para Piaget existe uma lógica da afetividade que não consiste na pura e simples imposição da lógica intelectual aos afetos intuitivos. Entre as normas lógicas e as normas morais só existem diferenças de graus. $\mathrm{O}$ ato voluntário, definido como instrumento de conservação dos valores no plano afetivo é para o autor análogo às operações no plano da inteligência. Inspirado em William James, Piaget entende que o ato voluntário implica um conflito entre duas tendências das quais a mais débil se transformará em mais forte no transcurso do ato voluntário (Piaget, 1953-54/1994, pp. 270-271).

De modo geral, Piaget propõe uma analogia entre a vontade e a operação. Nos problemas de inteligência é indispensável que o sujeito domine a configuração perceptiva do 
momento para fazer aparecer relações que não estavam na origem (dedução lógica). De maneira similar, a vontade consiste em superar uma configuração afetiva, mudar o ponto de vista para que se construam outras relações. Em ambos os casos há descentração. Para não entender isso como uma interpretação intelectualizada da vontade, é preciso lembrar que para Piaget não existem condutas puramente afetivas nem intelectuais. A vontade, na sua perspectiva, é uma regulação em segundo grau, regulação das regulações (ibid, p. 275-277).

Além dos atos voluntários livres, durante o quinto estágio da afetividade exposto no quadro dos paralelismos (cf. item 2.2), progressivamente aparecem outros sentimentos autônomos, que consistem em avaliações morais pessoais e sentimentos que podem entrar em conflito com os de obediência. Esses valores se organizam em um sistema novo de reciprocidade moral normativa e de respeito mútuo que difere do unilateral e enriquece os diversos sentimentos pré-existentes (ibid, p. 278). Assim, o ato de vontade consiste em subordinar a situação a uma escala permanente de valores. A vontade na ótica piagetiana não pode ser entendida em termos de um imperativo social, mas como uma regulação de regulações da conduta que implica mudar de ponto de vista e, portanto, resulta análoga à descentração.

Em linhas gerais, o respeito unilateral do período anterior se converterá em respeito mútuo, e os sentimentos morais vão adquirir certa autonomia uma vez que organizados a partir de um sistema de valores mais coerente e geral. Em relação ao pensamento préoperatório a conquista das operações e da lógica comporta uma expansão cognitiva e afetiva fundamental no desenvolvimento, porque consiste em "corrigir a intuição perceptiva, sempre vitima das ilusões do ponto de vista momentâneo, e, por conseguinte, em 'descentrar' o egocentrismo, por assim dizer, para transformar as relações imediatas em um sistema coerente de relações objetivas" (Piaget, 1964/1975, p. 73).

\subsection{A noção de crença}

Para abordar a noção de crença é preciso relembrar que o conhecimento do qual se ocupa Piaget é o científico, que difere do conhecimento místico e do metafísico e requer atitudes mentais específicas para ser definido como tal. Em contrapartida, as atitudes mentais a partir das quais Piaget explica a orientação do pensamento infantil (anteriormente detalhadas), contrapõem-se àquelas sustentadas pelo sujeito que constrói conhecimento científico. Uma atitude fundamental para a ciência é a capacidade geral de duvidar, no sentido de ter uma atitude crítica diante do aparente e do que outras pessoas possam afirmar sem 
apresentar provas e não se orientar exclusivamente pela configuração perceptiva. Se todo fenômeno natural e social fosse reificado e abordado intuitivamente pela sua aparência, ou se explicasse mediante postulados morais e finalistas, o conhecimento científico não teria razão de ser. A dúvida, definida no Dicionário Aurélio (Ferreira, 1993) como "incerteza sobre a realidade de um fato ou verdade de uma asserção" é sinônimo de "descrença". O termo "crenças" do título deste estudo foi escolhido entre outros, como "representações", "mitos", "idéias" ou "conhecimentos", que também são utilizados por Piaget em seus textos.

A palavra crença foi escolhida porque, coloquialmente, leva a pensar em questões de religião e remete a questões relacionadas à fé, certezas ou forças divinas. Para Piaget existe um processo de estruturação cognitiva de vários anos até atingir a capacidade de pensar formalmente, e nos primórdios desse processo a criança entende o mundo em termos de crenças. Previamente à estruturação do pensamento hipotético dedutivo, utilizado nas ciências, existem passagens gradativas e defasagens que fazem diferir a qualidade dos conhecimentos construídos (qualidade aqui é entendida como maiores ou menores níveis de abstração e reversibilidade). Desse modo, pouco a pouco a criança vai se afastando do egocentrismo como único sistema de referência para organizar seu pensamento.

A respeito do fator social, o contexto escolar valoriza o conhecimento científico e estimula sua construção. A "não consolidação" de atitudes mentais coerentes com as premissas do conhecimento científico (em contraposição às crenças) pode acarretar algumas confusões na sua apropriação, quando as crianças ainda interagem física e mentalmente com o meio a partir de atitudes mentais artificialistas, finalistas e animistas. A opção pela noção de “crenças" leva em conta que em um período do pensamento com níveis de egocentrismo elevado, as idéias que atravessam o espírito da criança "apresentam-se, repentinamente, sob a forma de crenças, e não de hipóteses a verificar" (Piaget, 1932/1994, p. 298). Assim, o pensamento pré-operatório se caracteriza por uma atitude natural de crença já que a dúvida ou a hipótese constituem condutas complexas e derivadas.

Piaget afirma que as formas pré-operatórias do pensamento são universais e se manifestam para além dos tipos de educação recebida porque "nada obriga a criança a selecionar certos detalhes com a exclusão de outros. Esta seleção parece ser obra de um interesse pelo artificial, cuja espontaneidade é difícil de contestar" (Piaget, 1926/2005, p. 285). A tenacidade e generalidade do artificialismo é uma característica do pensamento infantil que tem suas origens e repercussões tanto na vida afetiva como intelectual da criança. Porém, em relação aos conteúdos e ritmos de construção das crenças, o fator social é reconhecido por Piaget como influente no desenvolvimento das mesmas. A evolução das 
tendências artificialistas (que serão desenvolvidas mais adiante) difere entre os sujeitos. Estando ligadas ao problema do nascimento, as fontes de informação podem variar muito em qualidade, portanto, "seu desenvolvimento dependerá muito da educação recebida, a qual pode querer favorecer a adaptação ao real, quer manter as explicações míticas" (Piaget, 1945/1975, p. 318). Delval (1994) também aponta um aspecto afetivo do fato dos adultos favorecerem o pensamento mítico nas crianças:

durante muito tempo a norma tem sido não lhes dar explicações realistas e inventar fábulas acerca de como se produz o nascimento (...) o mais provável é que esse tipo de histórias só sirvam para minar a confiança das crianças no que seus pais lhes contam quando se interam da verdade e não parece ter nenhum efeito beneficioso" (Delval, 1994, p. 437).

O termo crença utilizado por Piaget exprime uma singular relação da criança do período pré-operatório com o saber, porque ela "acredita em todas as idéias que surgem em seu espírito, logo, acredita sem discussão, em tudo o que lhe contamos" (Piaget 1932/1994, p. 298). Seu pensamento não precisa de críticas em nome da razão, sendo que a crítica nasce da discussão e a criança de pensamento pré-operatório ainda pensa sob o império da coação intelectual e o respeito unilateral. Essas características organizam seus vínculos com os mais velhos, portanto "o verdadeiro é o que está de acordo com a Palavra adulta" (ibidem). Como já foi assinalado, a crítica só é possível entre iguais num marco de cooperação.

Para Piaget (1926/2005) o animismo existe muito mais na criança a título de orientação de espírito ou de esquema de explicação que como crença conscientemente sistemática. Essa afirmação se explica pelo fato de que o pensamento da criança é pouco consciente de si mesmo. A capacidade de justificação aparece tardiamente e a sistematização refletida sucede à sistematização implícita (época em que o animismo é eliminado quase totalmente da sua mentalidade). A tomada de consciência do animismo implícito ocorre só por necessidade e em duas situações. Quando algum fenômeno parecer contingente, bizarro e, sobretudo assustador, a criança colocará intenções na fonte desse fenômeno. Em segundo lugar, são os casos de obediência ou desobediência excepcional que levam a criança a uma reflexão. O resto sempre é atitude implícita.

Outra característica da crença radica em um particular modo de lidar com o fortuito. Essa forma de dar conta do contingente se organiza em torno do animismo e a magia, entre as quais existe uma distinção clara. Quando o acento causal é posto sobre o Eu, há magia. Se recair sobre o móvel, há animismo. Entre magia e animismo há tão-somente uma diferença de egocentrismo, que se define como a confusão da criança entre o Eu e o mundo. Para ela tudo gravita em torno dos homens. Mas esta concepção animista da natureza permite explicar a 
regularidade das coisas e também o fortuito. $\mathrm{O}$ interessante disso é que explicar o fortuito é suprimi-lo quando se procura enquadrá-lo a regras (morais e não físicas). Será necessário esperar até os 7-8 anos, aproximadamente, para que seja possível a construção da primeira noção de um determinismo físico, quando certos movimentos se explicarão como oriundos de uma obrigação inteiramente física (Piaget, 1926/2005, pp. 184-185).

No livro Da lógica da criança à lógica do adolescente, Piaget (1955/1976) explica que, diferentemente das crianças pequenas, um instrumento intelectual próprio da adolescência é a reflexão que ultrapassa o presente. $\mathrm{O}$ adolescente pode refletir acerca das possibilidades, indo além das situações vividas ou reais, começando assim a construir sistemas ou teorias. No caso da criança do período pré-operatório, ela não constrói sistemas porque não conta ainda com um pensamento auto-reflexivo e também não busca sistematizar suas idéias. É o pesquisador que, a partir das respostas das entrevistas, tem que observar quais são as reações sistemáticas das crianças. Na crença ainda não subjaz uma reflexão propriamente dita porque essa capacidade se define como "um pensamento em segunda potência ou pensamento sobre o próprio pensamento, e isto é indispensável para a construção de qualquer teoria” (ibid, p. 253). Em resumo, a crença infantil pode ser definida como uma convicção impermeável sem necessidade de verificação ou justificação, pois a criança "não se coloca a questão da verdade e não tem necessidade de colocá-la" (Piaget, 1945/1975, p. 215).

Com isso, poder-se-ia perguntar então se a curiosidade da criança pela sexualidade humana e a origem das coisas corresponderia a uma tendência infantil de "fazer filosofia". A perplexidade da criança frente às perguntas sobre os grandes mistérios da vida e da morte se apresenta de maneira espontânea pela urgência e dificuldade de lidar com o aleatório. Além disso, o problema do nascimento dos bebês em geral, implica, conseqüentemente, a pergunta pela própria origem e existência. Matthews (2001), autor do livro A filosofia e a criança, dedica um capítulo para criticar Piaget por não ter tido sensibilidade para o que ele denomina o "pensamento filosófico de crianças pequenas". Porém, na obra do próprio Piaget e a partir da noção de crença, é possível achar esclarecimentos a respeito dessa crítica:

Não é preciso dizer que a criança não produz mesmo nenhuma filosofia, no sentido exato da palavra, já que ela nunca procura organizar suas reflexões em nada que se assemelhe a um sistema (...) não se pode falar, senão metaforicamente, da filosofia da criança. (...) Ainda assim, embora os comentários espontâneos das crianças a respeito de fenômenos da natureza, da mente e da origem das coisas possam ser desconexas e incoerentes, podemos discernir em algumas delas tendências constantes, que reaparecem a cada novo esforço de reflexão. São essas tendências que podemos chamar de 'filosofias infantis' (Piaget apud. Matthews, 2001, p. 534). 
Lembrando que Aristóteles postula que "a filosofia começa pela admiração", Matthews afirma que se nos adultos interessados pela filosofia a admiração é uma atitude a cultivar, na criança resulta espontânea e, portanto é possível falar de uma filosofia na criança (ibid, p. 83). Porém, essa afirmação poderia ser problematizada entendendo que a "atitude de admiração" e a ingenuidade no modo de questionar não derivam automaticamente em uma filosofia como ciência. A filosofia adulta e sistemática, homologada às "filosofias infantis" é uma equação um tanto apressada que poderia desembocar em conceber as crianças como adultos em miniatura desestimando as particularidades do seu desenvolvimento cognitivo.

A partir da noção de crença, entendida como convicção, como compreender os limites das crianças às explicações científicas? A dificuldade do pensamento egocêntrico para perceber contradições é um fator que limita a "educação sexual" à assimilação ativa da criança. Como já foi mencionado, esta pesquisa procura focalizar essa particular assimilação da criança e não as estratégias de educação adulta. Essa singular assimilação se estende a todos os domínios do conhecimento, portanto a distorção do pensamento pré-operatório, junto com as fantasias originárias reveladas pela psicanálise, constitui o ponto de partida para entender as formas de argumentação e elementos comuns que surgiram nas entrevistas. Entender as formas de construção do conhecimento sobre a origem dos bebês permitiria, em conseqüência, entender certos limites da educação.

De modo geral a criança aprende os sinais coletivos do meio (não todos compreendidos) e soma os sinais individuais que se expressam em jogos simbólicos, na imitação representativa e nas suas imagens. A relação entre o caráter egocêntrico das trocas interindividuais e o caráter intuitivo e pré-operatório do pensamento é estreita (De Souza, 2004b). O conceito de assimilação na obra piagetiana traz como consequiência inerente, além da sua concepção de sujeito, a distinção entre informação e conhecimento. Discriminar esses termos enriquece a compreensão dos possíveis limites da educação, quando se parte da hipótese de uma progressão genética do conhecimento, que evoluirá para formas cada vez mais objetivas e complexas, sempre de maneira dinâmica e em concordância com as formas e os ritmos impostos pelo desenvolvimento cognitivo e afetivo. A criança pode receber informações detalhadas sobre o nascimento e a fecundação por meio de diferentes fontes, sejam seus pais, outros familiares, professores, colegas, a mídia, livros, etc. Porém, para que essa informação se assimile como conhecimento, deverá atravessar um processo de transformação, seleção, valorização e significação. Esse processo se desenvolve a partir de certas regularidades postuladas por Piaget. São as leis e formas das estruturas do pensamento 
que modelam essa informação do meio na sua passagem ao estatuto de conhecimento construído.

Entretanto, interesses, valorações e motivações também mudam ao longo do desenvolvimento afetivo do sujeito, o qual desembocará na preferência por objetos diferentes a assimilar e em ritmos e intensidade distintos em cada etapa. $\mathrm{O}$ par indissociável assimilaçãoacomodação, pilar da psicogênese piagetiana, a afasta do empirismo e do inatismo, sendo que a construção do objeto e do sujeito é recíproca porque eles se modificam mutuamente na sua interação a partir de relações dialéticas de influência e não de determinação. Dessa forma, o sujeito não recebe as informações do meio sem transformá-las.

Um dos contextos de assimilação por excelência, durante a infância e a adolescência, é o escolar. No que diz respeito ao papel da escola, Piaget afirma que o direito à educação moral e à formação da razão deve garantir que a criança consiga construir e participar da elaboração das normas para alcançar autonomia e a autoformação da razão. A educação escolar pode melhorar esses processos de formação se contempla a existência de relações complexas entre o professor e o aluno, e entre os alunos. Do contrário, a escola se separa da vida e restringe o desenvolvimento afetivo e intelectual (Piaget, 1972/1988).

Piaget insiste na idéia de que as estruturas intelectuais e morais das crianças são diferentes das dos adultos. À diferença de um estilo de ensino conhecido como "escola tradicional" que concebe a criança como um adulto pequeno e passivo, outras propostas consideram as características das estruturas do pensamento das crianças para planejar suas propostas e entendem a aprendizagem como uma assimilação de conteúdos. Dessa forma, para acomodar sua atividade às propriedades das coisas as crianças têm que assimilá-las. A inteligência não pode ser transformada por métodos de pura receptividade porque toda inteligência é uma adaptação, e toda adaptação comporta uma assimilação das coisas e um processo complementar de acomodação. No início da vida mental os objetos só têm interesse se constituem alimentos para a própria atividade e esse interesse irá mudando ao longo do desenvolvimento. A relevância do interesse no qual repousa qualquer trabalho de inteligência, é que ele constitui o aspecto dinâmico da assimilação (Piaget, 1969/1975).

De acordo com Piaget, aceitar essa idéia de evolução da inteligência não significa admitir estágios rígidos caracterizados por limites de idades. Implica considerar que a causalidade científica não é inata, mas construída paulatinamente, e que essa construção supõe tanto uma correção do egocentrismo inicial do pensamento como uma adaptação do espírito às coisas. Juan Delval (1994) destaca que desde muito pequenos, tanto meninas como meninos manifestam interesse pelos problemas relativos ao sexo, perguntam-se acerca da sua 
própria origem e realizam jogos referentes à gravidez e ao nascimento, por exemplo, colocando-se bonecos na barriga debaixo da roupa. Porém, as idéias das crianças acerca do nascimento são confusas, curiosas, e passam por diferentes etapas. A seguir, são apresentados alguns dos pressupostos teóricos dados por Piaget para entender essa psicogênese do conhecimento sobre a origem dos bebês.

\subsection{O problema do nascimento e os estágios do artificialismo}

Piaget outorga especial importância ao problema do nascimento dos bebês, tanto na perspectiva cognitiva como afetiva. Ao tratar a construção desse objeto de conhecimento, destaca o fato de a criança conceber os seres vivos sendo ao mesmo tempo dotados de vida e fabricados, como conseqüência da fusão entre o animismo e o artificialismo. O autor afirma que as crenças sobre o nascimento dos bebês permitem compreender as verdadeiras relações entre essas duas atitudes mentais. Segundo suas pesquisas baseadas no método clínico, em um primeiro momento a criança do período pré-operatório sustenta a pré-existência do bebê e as perguntas surgem em referência a onde estava antes de nascer. Logo, se perguntará acerca do como da formação dos bebês e o papel dos pais (Piaget, 1926/2005).

Nas primeiras perguntas, que supõem a pré-existência (estágio de pré-artificialismo), há uma ligação pais-criança no sentido de que a vinda do bebê é considerada querida e determinada pelos pais, mas sem que seja feita a pergunta sobre como o bebê pode existir. Alguns exemplos desse estágio são as idéias de que a mãe acha o bebê ou o come, e que os mortos reaparecem na forma de bebês. Não há ainda aí uma fabricação, mas há pelo menos uma ligação que a criança sente diretamente sem ter necessidade de precisar. As perguntas do segundo tipo se caracterizam pela necessidade de compreender essa ligação, o como do nascimento. Dois tipos de situações se evidenciam como resposta. Por um lado, o nascimento é assimilado a uma fabricação que incide sobre uma matéria viva independente dos pais. Por outro, a matéria por meio da qual os pais fabricam as crianças é procedente do próprio corpo dos pais: do sangue, da boca, do peito, do umbigo.

Ainda que a curiosidade da criança incida sobre a origem de todas as coisas, Piaget sugere uma ordem dos conteúdos. A sequiência dos interesses parece ser: interesse pelo nascimento, pela origem da espécie (o primeiro homem) e, por último, pela origem das coisas em geral. Desta forma, as questões do nascimento constituiriam o ponto de partida para as perguntas sobre a origem das coisas Nas suas palavras: "Podemos supor que é muitíssimo provável que a curiosidade relativa ao nascimento é o que está no ponto de partida das 
perguntas sobre a origem, tão abundantes entre os 4 e 7 anos, e que sua base é o artificialismo infantil" (Piaget, 1926/2005, p. 296). Essa apreciação constitui uma importante convergência com as postulações da psicanálise em relação às origens do pensamento, que será abordada mais adiante.

Quatro estágios do artificialismo infantil foram postulados por Piaget (ibid, pp. 298302) para entender as explicações das crianças a respeito da origem das coisas. Porém, esses estágios não serão utilizados estritamente para a análise dos dados aqui coletados, mas servirão de referência e orientação para a construção de níveis específicos. Vale ressaltar que as fases do artificialismo não são tão regulares como as da aquisição do número, das quantidades e o desenvolvimento operatório, e sempre apresentam contradições, mesmo de um dia para outro, e que, como em toda a teoria piagetiana, as idades são aproximadas. Além disso, no domínio das crenças sobre a origem, a causalidade "é de uma ordem inteiramente outra do que no das intuições lógicas, numéricas ou espaciais, que decorrem da manipulação e da verificação" (Piaget, 1945/1975, p. 318).

O primeiro estágio, nomeado artificialismo difuso, consiste na crença na vida espontânea das coisas e o predomínio da pergunta "de onde vêm os bebês?" O sentido é espacial e não causal. Há artificialismo porque a criança acredita que as ações são dirigidas ou influenciadas direta ou indiretamente pelos homens. Prepondera a ação do homem sobre as coisas, a ausência de um mito de origem e a presença do elemento mágico. As crenças deste período se caracterizam por sentimentos de participação (que precedem e anunciam as atitudes mágicas e as crenças artificialistas).

O segundo estágio, o artificialismo mitológico predomina nas crianças de 5/6 anos, quando a tendência é crer que as coisas são fabricadas pelos homens e são ao mesmo tempo vivas. Estabelece-se uma evidente semelhança entre fabricação e nascimento porque artificialismo e animismo se complementam sem necessariamente se opor. A partir dos 7/8 anos, em média, predomina o artificialismo técnico, quando a explicação deixa de ser mitológica. Durante este estágio a criança manifesta uma mistura de explicações naturais e artificialistas. Precisar o como da fabricação é precisar as dificuldades aí envolvidas e renunciar a crer na onipotência humana. É aprender a conhecer o real e suas leis. Neste período, artificialismo e animismo tornam-se contraditórios. O artificialismo se enfraquece e as leis morais são gradualmente substituídas por determinismo físico. À diferença dos estágios anteriores, as crianças reservam vida e consciência para os corpos animados por um movimento próprio. 
$\mathrm{Na}$ perspectiva piagetiana, os mitos espontâneos das crianças situam-se "a meio caminho entre o simbolismo lúdico ou imaginativo e a pesquisa própria à inteligência" (Piaget 1945/1975, p. 314). Eles são analisáveis do ponto de vista dos mecanismos simbólicos e préconceituais do pensamento. Nas crenças sobre a origem dos bebês constatam-se tendências artificialistas que evoluem do artificialismo difuso ao mítico, e depois ao imanente. A fabricação dos bebês se processa e assimila com o suporte do mito ou narrativa simbólica. $\mathrm{O}$ mito artificialista é um exemplo da estrutura pré-conceitual, próxima do esquema imagístico

porque ela ignora ao mesmo tempo a verdadeira generalidade e a identidade individual próprias aos conceitos e aos seus elementos (...) Sendo assim assimilador no sentido egocêntrico do termo e imagístico porque sua acomodação é insuficiente para atingir a generalidade do esquema conceptual, esse pensamento artificialista não é, portanto, ainda, de modo algum operatório" (ibid, p. 319).

O último estágio, na faixa dos 9-10 anos é nomeado como artificialismo imanente. Nesse período, progressivamente, desaparece a idéia de que a natureza é fabricada pelo homem. O artificialismo de forma humana ou teológica é transferido para a natureza, herdeira do homem. Porém, o finalismo resiste, as coisas continuam sendo "feitas para", e a natureza continua a ser penetrada de fins. Guardadas as proporções, trata-se do artificialismo da física de Aristóteles.

Essas tendências pesquisadas por Piaget permitem abordar a inter-relação entre o animismo e o artificialismo na construção do conhecimento a partir do enigma da origem. Para entender a progressão dessas crenças infantis, o autor toma exemplos dos próprios filhos, a partir de perguntas, afirmações, e jogos simbólicos nos quais aparece a temática dos bebês. Além disso, faz um levantamento dos registros das psicanalistas Melanie Klein e Sabina Spielrein e de professoras de crianças pequenas. Alude também aos símbolos freudianos dos sonhos de nascimento, como água, ovos, bolhas e vermes (simbolismo do pensamento inconsciente). Em resumo, considerando as idéias gerais das crianças sobre o nascimento, ainda que tenham recebido explicações ou não, elas admitem que saiam da mãe (ou ainda, do pai), do orifício anal, da urina, das fezes, do umbigo, do peito ou do pênis (Piaget, 1923a/1994).

Para Piaget, ainda que a criança tenha recebido esclarecimentos sobre a saída do bebê do corpo da mãe, continua perguntando pela formação de cada órgão como se tivesse sido fabricado separadamente. O autor ilustra com exemplos registrados por Melanie Klein: "mas de onde vem a cabecinha? De onde vêm os pequenos membros? De onde vem a barriguinha?" (Piaget, 1926/2005, p. 297). As perguntas da filha de Jung seguem a mesma linha: 
Como é que os olhos nasceram para dentro da cabeça? E a boca e as orelhas também cresceram assim? E os cabelos também? Como é que os ratinhos vêm a esse mundo bem peladinhos? Onde é que os pelos estavam antes? Será que a gente tem de botar sementinhas para isso? Como é que o Fritz entrou na mamãe? Alguém o colocou lá? Foi colocada uma sementinha? (Jung, 1910/1999, p. 33).

Como já foi mencionado, Piaget afirma que a criança se comporta como se o acaso ou a necessidade mecânica não existissem. Portanto, seu pensamento é dirigido pelo intencionalismo, já que tudo, na natureza, tem uma razão de ser em função da vontade e das necessidades humanas. Poder-se-ia então partir da hipótese de que essa forma finalista do pensamento infantil exige a elaboração de crenças para assimilar o problema da origem dos bebês e da sexualidade. Simultaneamente, além dessa tendência mental finalista e artificialista, a criança tem motivações e interesses intensos em relação à sexualidade, fato que será aprofundado no item sobre o desenvolvimento psicossexual segundo a psicanálise.

Sintetizando o que foi exposto, para atingir um panorama geral da pesquisa piagetiana sobre o artificialismo pode-se afirmar que:

as idéias das crianças sobre o nascimento dos bebês ou sobre as origens do homem seguem as mesmas leis que as idéias relativas à natureza em geral: artificialismo no ponto de partida, e explicação natural com vestígios de artificialismo imanente nos estágios superiores (Piaget, 1926/2005, p. 297-298).

Se o sentimento filial constitui fonte de artificialismo, aproximadamente aos 6/7 anos começa uma crise intelectual e moral da onisciência e onipresença dos pais ao mesmo tempo em que emerge uma crise do artificialismo mitológico e começa a tendência ao artificialismo técnico. O problema do nascimento se constitui em uma perturbação cognitiva e simultaneamente afetiva porque resulta um tema valioso e de especial interesse para a criança pequena e ao mesmo tempo escapa a sua capacidade de assimilação. Em linhas gerais, da interação do Eu com o mundo emergem perturbações que o sujeito tenta assimilar quando resultam interessantes. As perturbações podem ser: um obstáculo a assimilar, um objeto ou uma lacuna, quando ao sujeito lhe faltam recursos. Diante dessas perturbações como reage o sujeito? Para afrontá-las o sujeito conta com as regulações. Estas consistem em compensações, antecipações ou anulações das perturbações para voltar ao equilíbrio. Em resumo, trata-se de um jogo de perturbações/regulações/compensações que, segundo Piaget, é explicado pela teoria da equilibração. Essa equilibração é progressiva e se aperfeiçoa porque resulta qualitativamente mais expansiva com o desenvolvimento do sujeito. Para Piaget, a equilibração representa o fato de que "o sujeito trate de introduzir o máximo de coerência nas suas idéias, e de diminuir as contradições” (Piaget apud Bringuier, 1977/2004, p. 112). 
Para discutir o estatuto das teorias sexuais infantis psicanalíticas no contexto das crenças pré-operatórias sobre a origem dos bebês resulta interessante mencionar brevemente a pesquisa que Kohlberg (1966). A teoria cognitiva do desenvolvimento deste autor está baseada na psicogênese piagetiana e a partir desta concebe a identidade sexuada como o resultado de uma construção interna nascida da atividade própria do sujeito e determinada pela evolução das capacidades intelectuais. Para esse autor, a expressão de condutas sexuadas e a aquisição da identidade sexuada se desenvolvem por estágios. O interesse para este estudo se centra na constância de gênero, definida por Kohlberg como o conhecimento de que a criança será menino ou menina ao longo de toda a sua vida de maneira estável e fixa (Le Maner, 1997). Dessa forma, conceber a constância de gênero ${ }^{8}$ como uma construção cognitiva progressiva ajudaria a compreender, desde outra posição epistemológica, a teoria falocêntrica postulada por Freud, especialmente sua suposição de que a criança olha a ausência de pênis das mulheres, mas nega esse fato e continua pensando que vai crescer ou foi cortado.

Acerca das diferenças sexuais, Delval (1994) reconhece que é um tema de interesse tanto para meninos como para meninas: "podemos observar meninos que escondem seu pênis até atrás e dizem 'agora sou uma menina' ou meninas pondo-se algum objeto” (ibid, p. 437). A pesquisa de Kohlberg (1966) corroborou que as crianças menores de 5/6 anos ainda não têm segurança na identificação da "constância de gênero" e a partir das suas pesquisas, demonstra que meninos de 4 anos afirmam que quando crescerem serão mães. $\mathrm{O}$ procedimento de campo do autor consistiu em perguntar a crianças de 4 a 8 anos se uma menina (apresentada em uma imagem) poderia se transformar num menino se ela o desejasse, se brincasse com carrinhos ou se vestisse roupas de meninos e cortasse seu cabelo. Aos 4 anos a maioria responde que é possível, mas aos 6/7 já adquiriram a constância de gênero e sabem que o sexo é definitivo. Kohlberg defende a idéia de que para as crianças, a diferença genital não é um critério básico da classificação sexual. Para a criança o gênero é como a roupa: é uma etiqueta que varia (1966, p.78). Além de permitir futuros diálogos com alguns postulados da psicanálise, a pesquisa de Kohlberg, ao mostrar que a criança antes dos 6 anos define o ser homem ou mulher a partir de elementos contingentes, e não da diferença genital, permite refletir sobre as respostas coletadas nas entrevistas a respeito da diferença sexual nos bebês e que serão apresentadas posteriormente.

\footnotetext{
${ }^{8}$ Embora consideremos que seria mais preciso se falar em "constância de sexo" do que "de gênero", utilizaremos o conceito por se referir aos argumentos psicogenéticos que foram utilizados nesta pesquisa. Vale ressaltar, também, que o conceito desconsidera a possibilidade de mudanças de sexo por meio de cirurgias nos órgãos genitais, embora estas não acarretem em alterações genéticas.
} 


\section{DESENVOLVIMENTO PSICOSSEXUAL DA CRIANÇA NA PERSPECTIVA PSICANALÍTICA}

Neste capítulo serão abordados alguns dos conceitos psicanalíticos úteis para pensar o objeto de estudo desta pesquisa. A seleção dos conceitos resultou em três grandes temas. Em primeiro lugar, o desenvolvimento psicossexual da criança na perspectiva de Freud e um breve esboço do conceito Complexo de Édipo. Em segundo lugar, os aspectos psicodinâmicos do pensamento segundo o modelo freudiano de aparelho psíquico que fora desenvolvido especialmente nos textos denominados metapsicológicos. Por último, a noção de desejo de saber e preferência pulsional, especialmente na sua dimensão de origem da atividade intelectual na forma de teorias sexuais infantis. Essas teorias também serão contempladas nas suas distintas acepções à luz das contribuições de outros autores do campo da psicanálise.

A partir do levantamento bibliográfico foram considerados os textos de maior relevância sobre o desenvolvimento psicossexual da criança e a metapsicologia, especialmente: Três ensaios sobre a sexualidade, de 1905, Sobre as teorias sexuais das crianças, de 1908, Introdução ao Narcisismo, de 1914, Totem e Tabu, de 1914, Esboço da psicanálise, de 1938, entre outros, e os textos metapsicológicos como Formulações sobre os dois princípios do funcionamento mental, de 1911, e O inconsciente, de 1915.

\subsection{O desenvolvimento psicossexual}

O processo que Freud denomina como "desenvolvimento psicossexual da criança" se caracteriza por ser gradativo e implicar simultaneamente aspectos psíquicos e biológicos, como as fontes somáticas das zonas erógenas (1938/1974, p.107). Assim, ao longo desse desenvolvimento, a criança irá construindo fantasias e defesas sempre organizadas em fundamentos orgânicos e modalidades relacionais. O estudo do desenvolvimento foi necessário para entender a etiologia das neuroses, portanto, Freud teve que focar a compreensão de processos típicos de gênese mental. Em 1913, o autor se ocupa de explicar o interesse da psicanálise para a psicologia do desenvolvimento. Nesse texto argumenta que investigar a mente infantil é um importante objeto de estudo para a clínica, sendo que as impressões da infância influenciam tudo o curso da evolução posterior do indivíduo. Os desejos, impulsos e atitudes da infância não são destruídos, mas persistem e se sobrepõem ao 
que se originou deles. Freud oferece uma definição da psicanálise em uma ótica do desenvolvimento afirmando que esta

consiste em remontar uma determinada estrutura psíquica a outra que a precedeu no tempo
e da qual se desenvolveu (...) assim, desde o início, a psicanálise dirigiu-se no sentido de
delinear processos de desenvolvimento. Começou por descobrir a gênese dos sintomas
neuróticos e foi levada, à medida que o tempo passava, a voltar sua atenção para outras
estruturas psíquicas e a construir uma psicologia genética que também se lhe aplicasse
(...) delineou a continuidade entre a mente infantil e a mente adulta e observou também as
transformações e os remanejamentos que ocorrem no processo (Freud 1913/1996, p. 185, o
negrito é nosso).

Os processos que levam um nível de organização ao subseqüente e mais elevado são variados. Freud nomeia o desenvolvimento indistintamente como sexual ou da libido. A libido é definida como a manifestação da força da pulsão sexual (assim como a fome é a força da pulsão de nutrição). A vida sexual humana (ou função libidinal) não emerge como algo pronto, mas passa por uma série de fases progressivas que se apóiam em funções somáticas vitais. A proposta de admitir esse desenvolvimento sexual desde o nascimento resultou inovadora porque, no final do século XIX a dimensão sexual da criança era omitida ou era observada como correspondente a casos curiosos e assustadores como a depravação precoce (Freud 1905/1996, p. 163).

A primeira fase do desenvolvimento psicossexual é a oral, definida como o estágio de organização mais precoce no qual a zona erógena principal é a boca e a sua atividade sexual é a sucção ou chupar. A fase seguinte é a sádico-anal, durante a qual se estabelece um contraste entre ativo e passivo, e não ainda entre masculino e feminino. As pulsões de domínio desta etapa podem-se transformar em crueldade enquanto as tendências com fins passivos se vinculam à zona erógena do orifício anal.

A partir dos três anos, aproximadamente, inicia-se uma nova fase denominada fálica que segundo Freud mostra muita semelhança com a vida sexual do adulto. Esta etapa é descrita como o momento das primeiras manifestações da curiosidade sexual das crianças a partir da construção de hipóteses que resolvam os enigmas do corpo e da origem. O conceito de fase fálica aparece na obra freudiana em 1923, de modo tardio em relação às demais, que já apareciam em 1905. Freud assinala que durante a organização genital infantil só se considera um órgão genital, o masculino, e a primazia é do falo. A ausência do pênis nas meninas é rejeitado (negado) e as crianças acreditam que vêem um pênis. Dessa forma, encobrem a contradição dizendo que ele é pequeno ainda, mas vai crescer. A antítese que se apresenta é entre órgão genital masculino ou castrado (Freud, 1923/1996, p. 158-161). Nessa fase se 
apresentam fenômenos mentais e sociais da vida sexual, porém, as crianças entre os 3 e 8 anos aprendem a ocultar seu caráter sexual (Freud, 1916/1996). Conforme diz o autor:

As pulsões de olhar e adquirir conhecimento (pulsões escopofílica e epistemológica) estão funcionando poderosamente; os genitais realmente desempenham seu papel na vida sexual apenas como órgãos de excreção da urina. As pulsões componentes parciais dessa fase não existem sem objetos, mas esses objetos não convergem necessariamente em um único objeto (ibid, p.331).

O período de latência não leva o nome de fase porque ainda que possam ser observadas manifestações sexuais não é, a rigor, uma nova organização da sexualidade e se inicia aproximadamente entre o quinto e o sexto ano de vida (Laplanche e Pontalis, 2009). Coincide com a declinação do complexo de Édipo e não significa uma interrupção da atividade e interesses sexuais. Porém, as experiências e impulsos mentais anteriores, sucumbem na amnésia infantil (Freud, 1917/1996, pp. 330-332). Durante este período, as teorias sexuais não conservam o caráter típico e original da primeira infância, quando os componentes sexuais eram expressos sem inibições. Neste período, os esforços intelectuais já não possuem significação patogênica e a sua variedade depende dos esclarecimentos que a criança recebe. Nas palavras de Freud: "Aproximadamente do sexto ao oitavo ano de vida em diante, podemos observar uma parada e um retrocesso no desenvolvimento sexual, que, nos casos em que culturalmente há mais condições, podemos chamar de período de latência" (Freud, 1916/1996, p. 330).

Contudo, durante este período, a tentativa de decifrar os enigmas do sexo ativa traços inconscientes do primeiro período e assim as novas descobertas se misturam com idéias falsas e resíduos das teorias sexuais infantis de fases anteriores (Freud, 1908/1996, p. 202). Também nessa etapa se consolidam as forças que limitarão a pulsão sexual à maneira de diques como a vergonha, o nojo, e as exigências de ideais estéticos e morais (reforçados em grande parte pela educação). Como foi dito, a energia sexual infantil não cessa, mas é desviada do uso sexual e voltada para outros fins. Esse processo de orientação para novas metas é denominado sublimação (Freud, 1905/1996, p. 167).

Em linhas gerais, segundo Freud, todos os processos afetivos mais intensos, inclusive as excitações por temor, se propagam para a sexualidade (ibid, p. 192). Porém, pode-se explicitar que se a sexualidade é um dos eixos do corpo teórico psicanalítico, a sua concepção difere do senso comum que a equipara à genitalidade. A singular acepção freudiana deve ser sublinhada para evitar confusões. No prefácio aos Três ensaios sobre a teoria da sexualidade da edição de 1920, Freud se defende dos rótulos de "pansexualismo" dirigidos à psicanálise afirmando sua idéia de uma sexualidade ampliada e próxima ao conceito de "Eros" de Platão. 
Tanto a sexualidade como o infantil têm significativa importância na psicanálise. Prova disso resulta o valor traumático da sexualidade e a força dos desejos e fantasias infantis na formação de sonhos e sintomas de adultos. Deve-se assinalar que infantil não é somente relativo a criança, que identifica o sujeito que atravessa a etapa evolutivo-cronológica denominada infância. Em decorrência disso, a sexualidade infantil não recobre somente o que poderíamos nomear "a sexualidade das crianças", mas a supera amplamente nos seus alcances (Vanier, 1996). Essa distinção não significa que a criança não seja objeto de interesse para a psicanálise. A criança-sujeito da psicanálise é antes de tudo sujeito do inconsciente que se manifesta a partir de um modo de funcionamento psíquico singular e atravessa conflitos que lhe são próprios. Desde a primeira infância existem sinais de atividade corporal e intelectual ligadas à sexualidade e que poderão ser encontrados mais tarde na vida erótica adulta (como, por exemplo, a fixação a objetos específicos). A pedra angular do Complexo de Édipo na clínica com adultos é o principal testemunho disso.

\subsection{O complexo de Édipo como primeiro conflito psíquico}

No que se refere ao desenlace da problemática edípica (que "atingiria" a uma parte das crianças da faixa etária estudada), vale assinalar que ele traz como resultado o início da identidade sexual, o ideal do Ego e a formação do Superego (instância representante da consciência moral e do sentimento de culpa). Como já foi mencionado, para a psicanálise o complexo de Édipo é um dos conflitos universais dos seres humanos. Segundo Nasio (2007) pode ser entendido de várias maneiras: como uma "chama de sexualidade" vivida pela criança no cerne da relação com os pais, como uma fantasia sexual modelada no inconsciente, e como a matriz de nossa identidade sexual. Para o autor, aos quatro anos, o pênis convoca os olhares, atiça a curiosidade dos meninos e das meninas e lhes inspira fábulas, ficções e teorias infantis. O conceito de teorias sexuais infantis na psicanálise também abre a discussão acerca da relação do sujeito com o saber, especialmente com o saber sobre a origem e a sexualidade, que surge durante o período edipiano.

Como se produz o desenlace do complexo de Édipo? Na perspectiva freudiana, a sua “dissolução" nos meninos é contundente pelo choque com a castração ameaçada e traz como conseqüência investimentos libidinais dessexualizados e sublimados. As meninas experimentam um sentimento narcísico de humilhação ligado à inveja do pênis. $\mathrm{O}$ reconhecimento da distinção anatômica entre os sexos a faz abandonar a idéia de competir com os meninos. Assim, a libido da menina desliza para uma nova posição: a equação pênis- 
criança. Ela abandona seu desejo de pênis por um filho, e toma o pai como objeto de amor e a mãe, de ciúmes. Segundo Freud, nas meninas o complexo de Édipo é uma formação secundária porque a operação de castração o precede e o prepara. Em meninas e meninos, a distinção anatômica dos sexos e a situação psíquica aí envolvida correspondem à diferença entre uma castração que foi executada e outra que foi ameaçada. Nas suas palavras, "enquanto nos meninos, o complexo de Édipo é destruído pelo complexo de castração, nas meninas ele se faz possível e é introduzido através do complexo de castração" (Freud, 1925/1996, p. 285).

O complexo de Édipo é constituinte da sexualidade humana e nenhuma criança escapa dele pelo extenso período do filhote humano em dependência dos seus pais. A posição ativa da criança a respeito do Superego herdeiro do complexo de Édipo se evidencia no fato de que a sua excessiva severidade nem sempre provém de um modelo fornecido pelos pais reais. $\mathrm{O}$ Superego "não segue um modelo real, mas corresponde a força da defesa utilizada contra a tentação do complexo de Édipo" (Freud, 1938/1974, p. 149). Assim Freud questiona que o senso moral seja adquirido pelos homens exclusivamente por meio da educação, da vida social, ou por meio da imitação e internalização de normas externas. Ressaltando a construção ativa da criança, a psicanálise (assim como a psicogênese piagetiana) se posiciona por fora do relativismo cultural e do determinismo social.

Outro conceito chave para entender essa concepção ativa de sujeito da psicanálise é o de séries complementares. Essas séries, postuladas para explicar a etiologia das neuroses, consideram o desenvolvimento do sujeito a partir da interação de fatores constituinteshereditários e de vivências acidentais. Segundo Freud, a causa determinante de todas as formas assumidas pela vida mental humana deve ser buscada na ação recíproca entre as disposições inatas e as experiências. Sendo assim, na psicanálise, a distinção entre o normal e o patológico se dilui porque os sofrimentos em geral podem se definir como "desarmonias quantitativas". As diferenças são de quantidade de energia e não de qualidade nos mecanismos psíquicos. Freud (1938/1974, p. 142) assinala que "não é cientificamente viável traçar uma linha de demarcação entre o que é psiquicamente normal e anormal". Ainda que assuma as implicações práticas da sua distinção, para ele seu valor é convencional.

\subsection{Aspectos psicodinâmicos do pensamento e adaptação à realidade}

O aparelho psíquico descrito pela psicanálise está constituído por modos de funcionamento que diferem segundo o sistema no qual tem origem, mas também segundo momentos do desenvolvimento desse aparelho que, progressivamente abandona a primazia do 
princípio de prazer. Sendo assim, o aparelho psíquico da criança comportaria diferenças funcionais em relação ao adulto. Para explicar essas diferenças, neste item se aprofundará a definição do inconsciente (noção fundadora da psicanálise) a partir de algumas das suas características, especialmente as apontadas por Freud no texto $O$ inconsciente (1915), para logo focalizar as características dos processos primários e secundários. Isso se justifica não só por ser a psicanálise um dos referenciais teóricos da pesquisa, mas porque o conceito de inconsciente e outros aspectos metapsicológicos são retomados por Piaget para explicar o pensamento da criança, principalmente em relação aos mecanismos do pensamento simbólico (inconsciente). Para tanto, parte-se do referencial teórico de alguns textos nos quais Freud indagou sobre os aspectos dinâmicos dos sistemas do aparelho psíquico e de algumas de suas hipóteses em relação à progressiva adaptação psíquica ao principio de realidade, inicialmente compreendida nas suas considerações sobre as crianças.

Em que consistem as características mencionadas por Freud entre os sistemas Inconsciente, Pré-consciente e Consciente? Em 1915, com a instauração da metapsicologia, se postulam novos aportes que enriquecem a definição de processos primários e secundários de 1895. Para sustentar teoricamente o postulado do inconsciente, Freud precisa explicá-lo e descrevê-lo em relação aos outros dois sistemas do aparelho psíquico. Assim, os três sistemas (Consciente, Pré-consciente e Inconsciente) devem ser abordados holisticamente levando em consideração as suas relações, conflitos e diferentes legalidades. A noção de processos primários e secundários define dois modos de funcionamento do aparelho psíquico e sua oposição é correlativa ao principio de prazer e de realidade.

Em linhas gerais, os primários caracterizam o sistema Inconsciente, eles deixam fluir livremente a energia que passa sem traves de uma representação à outra pelos mecanismos de deslocamento e condensação e tendem a catetizar as representações ligadas a experiências de satisfação (Laplanche e Pontalis, 2009). O sistema inconsciente tem como núcleo os impulsos carregados de desejo que podem ser coordenados entre si (somente o desejo consegue movimentar o aparelho). Outra característica relevante é que nele não há lugar nem para a negação, nem para a dúvida ou a certeza (Freud, 1915/1996).

No sistema pré-consciente/consciente domina o processo secundário. Os processos secundários ligam a energia para que fluxa de forma controlada, a satisfação é adiada e permitem experiências mentais que avaliam as satisfações possíveis. Constituem as clássicas funções de pensamento, atenção, juízo, raciocínio, e ação controlada. Tornam-se possível pela constituição do Ego, cuja função é inibir o processo primário. Ambos os processos tem 
implicações genéticas, por ser resultado da progressiva diferenciação do Ego a respeito do Id (Laplanche e Pontalis 2009, pp. 302-304).

No Inconsciente os processos são atemporais, dispensam pouca atenção à realidade e estão sujeitos ao princípio de prazer. A descarga do Inconsciente passa à inervação somática por meio do Pré-consciente. Os processos secundários desse sistema Pré-consciente apresentam uma inibição para a descarga e a sua energia funciona dando ordem temporal aos conteúdos representacionais. No entanto, Freud adverte para não fazer generalizações apressadas em relação aos dois sistemas porque desse modo aparecem no ser humano adulto, "no qual o sistema Inconsciente só atua como uma fase preliminar da organização 'mais elevada"” (ibid, 192-194). Essa organização mais elevada (expressão recorrente na obra de Freud) se refere à etapa consciente da organização psíquica.

Os processos primários também são definidos como investimentos de desejo levados ao ponto da alucinação com produção de desprazer. Os secundários se definem como processos que dependem de um bom investimento do Ego e representam versões atenuadas dos processos primários. A correta utilização das indicações da realidade constitui a sua precondição (Freud, 1895/1996, p. 379). Por ser resultado de um processo de progressiva diferenciação, ambos participam da construção das teorias sexuais infantis.

O período de pesquisas sexuais infantis é, na ótica freudiana, a primeira tentativa de trabalho intelectual. Pensar a criança em termos metapsicológicos implica considerar a prioridade cronológica dos processos primários assinalada por Freud pelo fato de estarem presentes no aparelho psíquico desde o princípio. Para o autor, os processos secundários se desdobram somente com o decorrer da vida, com o objetivo de inibir e sobrepor-se aos primários. Esse aparecimento tardio traz duas importantes conseqüências: em primeiro lugar, os desejos inconscientes exercem uma força que será aquecida pelas tendências anímicas posteriores ou desviada para objetivos mais elevados; em segundo lugar, muito do material mnêmico fica inacessível ao investimento pré-consciente. Assim, as moções de desejo provêm da infância e elas não podem ser inibidas nem destruídas (Freud, 1900/1996, p. 629).

Outro postulado que deve ser considerado ao estudar o inconsciente descrito pela psicanálise é que tudo o que é recalcado deve permanecer inconsciente; mas o recalcado não abrange todo esse sistema. Para defender a tese do inconsciente, Freud se apóia na idéia de que o conteúdo da consciência é muito pequeno, sendo que a maior parte do que se chama "conhecimento consciente" deve permanecer por muito tempo em estado de latência, ou seja, inconsciente. Diferentemente da psicologia da época o grande aporte freudiano é negar a equivalência entre o psíquico e o consciente (Freud, 1915/1996). Se esta afirmação é correta, 
pode-se pensar que as respostas das crianças nas entrevistas são como a ponta de um iceberg. A ponta constituiria o consciente, ou seja, o resultado de mecanismos psíquicos que em analogia com a imagem do iceberg, constituiriam a sua parte submersa e, portanto, a de maior magnitude. Porém, é preciso entender que a palavra "inconsciente" tem aqui um duplo sentido. Por um lado, adjetiva mecanismos desconhecidos para a criança e, por outro, designa uma legalidade própria, entendendo os processos primários como o modo de funcionamento do inconsciente como instância psíquica.

O próprio Freud reconhece a dificuldade de evitar ambigüidades a respeito das instâncias psíquicas, pois as palavras consciente e inconsciente são utilizadas às vezes no sentido descritivo e outras no sistemático. Além disso, é preciso considerar o aparelho psíquico a partir de três dimensões. Freud postulou um aspecto dinâmico dos processos mentais, um de topografia psíquica (ou seja, os sistemas nos quais se verificam) e um aspecto econômico relacionado com as quantidades de excitação. Desta forma Freud apresenta a descrição dessas três dimensões de análise dos processos psíquicos como uma metapsicologia $(1915 / 1996)$.

A partir das contribuições de Piaget sabe-se que a atitude mental da criança e suas estruturas de assimilação do mundo têm especificidades. Uma delas é que seu pensamento é menos consciente de si mesmo em relação ao do adulto. Em decorrência disso, e levando em consideração que Piaget estabeleceu claras correspondências entre o pensamento simbólico (inconsciente) e o pensamento da criança, resulta pertinente aprofundar a abordagem dos mecanismos inconscientes estudados pela psicanálise.

\subsection{Relações de cooperação entre os sistemas e a função do Ego}

A psicanálise se caracteriza por evidenciar a existência de um conflito inerente a todo ser humano entre os seus desejos e a repressão da cultura, ao mesmo tempo em que entre as suas próprias instâncias (Ego, Superego e Id). Porém, no texto $O$ inconsciente (1915), Freud surpreende revelando que "o Inconsciente permanece vivo e capaz de desenvolvimento, mantendo grande número de outras relações com o Pré-consciente ${ }^{9}$ entre as quais a de cooperação" (ibid, p. 195). Os resultados dessas relações são chamados "derivados". Neles, o

\footnotetext{
${ }^{9}$ No texto $O$ inconsciente, Freud não realiza uma distinção categórica entre os sistemas pré-consciente e consciente. Assinala que pela capacidade de se tornar consciente "também denominamos o sistema consciente de pré-consciente". Ambos compartilham suas características, ainda que entre eles haja uma censura não muito rigorosa. O consciente às vezes não é consciente, mas latente. $\mathrm{O}$ "tornar-se consciente" depende de uma hipercatexia e da função psíquica da "atenção" do pré-consciente voltada para certas direções. (pp. 178 e 196-7).
} 
Inconsciente se manifesta inclusive influenciado pelo Pré-consciente. Exemplos desses derivados são as fantasias de crianças, pessoas normais e neuróticas e também as formações substitutivas. A noção de "derivados" é importante porque a clínica psicanalítica não implica fazer uma simples tradução do sistema Inconsciente ao Consciente.

A relação de cooperação entre instâncias permite que o recalcamento do impulso inconsciente seja removido para que a sua atividade seja admitida como reforço dos objetivos do Ego. Nessas situações o Inconsciente é definido por Freud como ego-sintônico. Porém, a influência da legalidade inconsciente se faz evidente e as tendências do Ego que são reforçadas se mostram diferentes do normal e com uma resistência semelhante à dos sintomas obsessivos (Freud, 1915/1996).

No capitulo I do Esboço da psicanálise, que leva o título de "O aparelho psíquico", Freud afirma que chegou ao conhecimento do aparelho pelo estudo do desenvolvimento individual dos seres humanos (1938/1974, p. 103). O Id é apresentado como a mais antiga das instâncias do aparelho, sede das pulsões que se originam da organização somática. Logo após, o Id sofre modificações sob a influência do mundo externo, desenvolvendo-se em uma organização especial intermediária entre essa instância psíquica e o mundo, chamada Ego. Segundo Freud, as principais funções do Ego são: comandar o movimento voluntário e a autopreservação, evitar estímulos excessivamente intensos, armazenar experiências, lidar com estímulos moderados (adaptação) e aprender a produzir modificações no mundo externo para seu benefício. Em relação ao mundo interno, o Ego controla as exigências das pulsões, adiando a satisfação para ocasiões favoráveis ou suprimindo-as.

Um ano antes da sua morte, Freud reafirma o que foi postulado anteriormente em sua obra. As diferenças entre o estado inconsciente e o pré-consciente/consciente residem em relações dinâmicas de uma energia livremente móvel e outra ligada, respectivamente, e também nas leis às quais obedecem. São as leis dos processos do Inconsciente e do Id, denominadas processos primários, e do Ego e do pré-consciente, denominadas processos secundários. Considerando a segunda tópica, postula que na dissecação topográfica do aparelho psíquico em Ego e Id, a diferença de qualidade entre pré-consciente e inconsciente corre paralela (1938/1974, p. 116).

Essas diferenças são assinaladas desde A Interpretação dos sonhos (1900). Freud argumenta que o processo secundário impõe uma inibição e correção ao processo primário que se esforça por descarregar excitação e estabelecer uma identidade perceptiva com a vivência de satisfação. Diferentemente, o processo secundário busca uma identidade de pensamento com essa vivência. Se o processo primário não fosse inibido estaríamos 
alucinando continuamente e careceríamos de toda possibilidade de pensar e, portanto, de sobreviver. O pensar para Freud não passa de uma via indireta desde a lembrança de satisfação à tentativa de atingi-la novamente por meio de experiências motoras: "o pensar tem que se interessar pelas vias de ligação entre as representações sem se deixar extraviar pelas intensidades dessas representações" (Freud, 1938/1974, p. 629). O autor afirma também que a consciência busca atingir um refinamento da operação do pensamento, porém, ele está sempre exposto a um falseamento por interferência do princípio de prazer/desprazer.

Sendo pouco provável que um organismo continue vivo regido exclusivamente pela repressão do desagradável e o menosprezo da realidade objetiva, Freud postula uma gênese do pensar. No texto Formulações sobre os dois princípios do funcionamento mental, afirma que o pensar se origina na suspensão da descarga motora e na conseqüente capacidade de representação. Permite ao aparelho psíquico suportar a tensão do estímulo por meio de uma transformação dos investimentos livremente deslocáveis em investimentos ligados, e por meio de uma elevação do nível do processo de investimento em seu conjunto (Freud, 1911/1996).

O pensar, em sua origem, foi inconsciente e logo depois adquiriu novas qualidades perceptíveis para a consciência unicamente pela ligação com os restos de palavras. Porém, "na gênese do principio de realidade, uma classe de atividade do pensar se escandiu; ela se manteve apartada do exame de realidade e permaneceu subordinada somente ao princípio de prazer" (ibid, p. 240). Essa atividade é o fantasiar, considerada como uma expressão da tendência do nosso aparelho psíquico a aferrar-se ao princípio de prazer. Pode-se lembrar aqui que a direção do pensamento da criança é, segundo Piaget, a da imaginação e não a da pesquisa. Para a psicanálise, as fantasias são as formas de atividade mais rica em processos primários, no entanto carregam a marca dos processos secundários, sob a forma pela qual são atingidos (Chiland, 1993).

Como já foi comentado, Freud postula que no início do desenvolvimento só há processos primários no aparelho, ou seja, que tem prioridade cronológica. Deles, no decorrer da vida, se desdobrarão os secundários que alcançarão primazia no apogeu da vida. As conseqüências da intervenção dos processos secundários resultam especialmente claras no encontro da sexualidade. Se o Ego recorre à transmudação do Ego-prazer ao Ego-realidade, as pulsões sexuais experimentam modificações que as levam desde o auto-erotismo inicial até o amor de objeto. As pulsões sexuais que encontram satisfação no corpo próprio não atingem a frustração que institui o princípio de realidade. Por isso, para Freud (1911/1996), a relação entre as fantasias e as pulsões sexuais é estreita. 
Assim como Piaget, Freud assinala que as fronteiras entre o Ego e o não-Ego do indivíduo devem ser construídas, não sendo representadas de imediato. O Ego da criança é fraco e imaturo para afrontar o perigo da castração e fracassa na tarefa de dominar as excitações sexuais. Portanto, realiza tentativas de defesa que são momentaneamente eficazes. Essa é a precondição essencial da neurose: um desenvolvimento do Ego atrasado em relação ao desenvolvimento libidinal. Em decorrência disso, o Ego se libera das exigências pulsionais através do recalcamento. Segundo Freud, durante esse período da vida outra tendência freqüente para desviar exigências aflitivas do mundo é a negação das percepções que trazem ao conhecimento uma exigência oriunda da realidade. Conhecer certas coisas produziria uma angústia a ser evitada mediante tentativas de desligamento da realidade. Porém, a negação é sempre suplementada por um reconhecimento e o resultado disso depende de qual das duas atitudes contrárias pode se apoderar da maior energia psíquica. Contudo, o Ego, na difícil tarefa de defesa do mundo externo e interno nunca atinge um sucesso completo (Freud, 1938/1974).

$\mathrm{Na}$ ótica freudiana, a frustração advinda da realidade é imposta no curso do desenvolvimento humano. Ela atua como uma força proveniente das "exigências da vida" e da educação (qualquer que seja seu estilo). As pulsões de auto-preservação são mais fáceis de educar e cedo aprendem a "adaptar-se à necessidade e a moldar seus desenvolvimentos de acordo com as instruções da realidade" (Freud, 1916/1996, p. 358). Diferentemente, as pulsões sexuais são mais difíceis de educar porque estão ligadas a outras funções corporais e são "rebeldes" e inacessíveis à influência educadora da necessidade real. No início do período de latência, o Ego

descobre que lhe é inevitável renunciar à satisfação imediata, adiar a obtenção de prazer, suportar um pequeno desprazer e abandonar inteiramente determinadas fontes de prazer. Um Ego educado dessa maneira tornou-se 'racional'; não se deixa mais governar pelo princípio de prazer, mas obedece ao princípio de realidade, que, no fundo, também busca obter prazer, mas prazer que assegura levando em conta a realidade, ainda que seja um prazer adiado ou diminuído. A transição do princípio de prazer para o princípio de realidade é um dos mais importantes passos na direção do desenvolvimento do Ego (Freud 1916/1996, p. 360).

Também na sua última obra (Esboço de psicanálise, 1938/1974) Freud integra a segunda tópica e afirma que o processo primário intervém nos elementos psíquicos do Id. Esse processo difere daqueles que resultam familiares da percepção consciente da vida intelectual e emocional, porque estão isentos das criticas da lógica. Uma das funções do Ego consiste em realizar a passagem dos acontecimentos do Id a um nível dinâmico mais alto. Essa função se realizaria transformando a energia livremente móvel em energia ligada como 
no estado pré-consciente. A função do Ego, orientada pelo princípio de realidade, resulta, nas palavras de Freud, "construtiva" porque interpola a atividade do pensamento entre as exigências das pulsões e as ações que a satisfazem (ibid, p. 143-144). Diante do que foi exposto, e sabendo que as fronteiras do Ego e não-Ego ainda não estão consolidadas nas crianças, serão analisadas as singulares características de um tipo de produção simbólica que responde à legalidade de um aparelho psíquico diferente do adulto: as teorias sexuais infantis.

\subsection{Teorias sexuais infantis: desejo de saber sobre a origem e origem do desejo de saber}

A pergunta pela origem dos bebês trata, para Freud (1907/1996, p. 126), “da questão mais remota e premente a atormentar a humanidade imatura". Porém, existe outro assunto que pode despertar o desejo de saber: as diferenças sexuais. Nas suas palavras:

Se pudéssemos despojar-nos de nossa existência corpórea e observar as coisas da terra com uma nova perspectiva, como seres puramente pensantes, de outro planeta, por exemplo, talvez nada despertasse tanto a nossa atenção como o fato da existência de dois sexos entre os seres humanos (Freud 1908/1996, p. 193).

Para entender a gênese do desejo de saber sobre a origem é preciso lembrar que, segundo Freud, a curiosidade das crianças sobre a sexualidade não surge de maneira espontânea ou por necessidades inatas. Ela é ocasionada por um acontecimento de suma importância: o nascimento de um irmão, ou o temor de que isso aconteça (Freud 1910, p. 86; 1908 , p. 193; 1907, p. 126) ${ }^{10}$. A chegada de um irmão é provocadora de teoria sexual infantil porque as pulsões egoístas dominam a criança quando suspeita a chegada de um novo bebê na sua família ou observa essa situação em outros lares. Dessa forma, as perguntas dos porquês, primeiras manifestações da pulsão de saber, emergem da ameaça de perder o lugar central no amor dos pais e de uma necessidade de controle dessa situação angustiante. Nesse contexto a criança tem que afrontar a dificuldade de explicar o fenômeno da origem dos bebês e desse bebê em particular que o tirará de seu lugar de único objeto de amor parental.

A chegada potencial ou real de um irmão merece uma atenção especial para Freud. Em 1900, quando explica os sonhos típicos, dedica uma parte aos sonhos da morte das pessoas queridas (pais, irmãos, etc.). Acerca da relação da criança com seus irmãos, o autor rejeita a expectativa de que esse vínculo seja amoroso ou de amizade. Inclusive os adultos que sentem apego pelos irmãos experimentaram hostilidade por eles durante a infância. Segundo Freud,

\footnotetext{
${ }^{10} \mathrm{Em}$ algumas ocasiões Freud considera as diferenças sexuais como o primeiro enigma a captar o interesse da criança. Neste trabalho se considera que ambos os problemas estão intimamente relacionados; portanto não é importante descobrir a ordem cronológica da sua aparição.
} 
o filho mais velho maltrata o mais novo, fala mal dele e rouba-lhe seus brinquedos, ao passo que o mais novo se consome num ódio impotente contra o mais velho, a quem inveja e teme, ou enfrenta seu opressor com os primeiros sinais do amor à liberdade e com um senso de justiça (1900/1996, p. 278).

Freud assinala o vínculo fraternal precoce como um momento não só inaugural em relação ao desejo de saber, mas também ao desenvolvimento da moral. Durante um primeiro período de "egoísmo", as crianças sentem intensamente suas necessidades e lutam para satisfazê-las, "especialmente contra os rivais, outras crianças, e, acima de qualquer outra coisa, contra seus irmãos e irmãs" (Freud, 1900/1996, p. 278). ${ }^{11}$

A atitude hostil da criança diante do irmão recém nascido é freqüiente segundo a perspectiva freudiana, ainda que passe despercebido ao observador e posteriormente permaneça no adulto como desejos inconscientes de épocas anteriores. Uma passagem de um poeta suíço citada por Freud lembra essa vivência infantil: "eu era suficiente, no que dizia respeito a mim: por que havia de querer um irmão? E ele não era apenas inútil, era positivamente um obstáculo" (Spitteler, 1914 apud Freud, 1900/1996, p. 279). O caso do pequeno Hans, paradigmático em psicanálise com crianças, mostra como o menino observou as mudanças da sua mãe grávida e estabeleceu a relação entre o aumento de tamanho da barriga materna e o aparecimento do bebê. Aos 4 anos e meio começou a fazer claras alusões sobre os conhecimentos construídos a esse respeito (Freud, 1908/1996, p. 158).

A partir disso, a hostilidade fraterna explicada por Freud como produto do egoísmo infantil poderia corresponder, funcional e paralelamente, às características da afetividade egocêntrica e de narcisismo intelectual postulada por Piaget, que estariam desestabilizadas e perturbadas diante da chegada de um irmão.

O trabalho do pensamento acerca desse problema coexiste com a própria excitação orgânica até que a atividade de investigação finaliza por causa da suposição de que a mãe também tem pênis. Segundo Freud (1908/1996), nesse ponto do trabalho intelectual, a criança enfrenta o seu primeiro conflito psíquico porque algumas das suas concepções de preferência pulsional são incorretas na perspectiva dos adultos ou de outros colegas mais velhos. As concepções avaliadas como "boas" (produtos da educação e que resultam em uma cessação da própria reflexão) se tornam dominantes e conscientes, enquanto que as outras se tornam reprimidas e inconscientes. Assim se forma, para Freud, o complexo nuclear das neuroses

\footnotetext{
${ }^{11}$ Essa rivalidade é historicamente recorrente na literatura infantil (como em Cinderela), nos relatos bíblicos (a exemplo de Caim e Abel), na mitologia e na história (desde Rômulo e Remo) e também nos filmes. Recentemente, o filme francês $O$ pequeno Nicolau, de Laurent Tirard, narra a história de um menino profundamente angustiado diante da possibilidade da chegada de um irmão e, junto com seus colegas da escola, alimenta a fantasia de que se isso suceder seus pais deixarão de amá-lo e o abandonarão na floresta.
} 
(que logo após será o complexo de Édipo). Surge de um conflito entre as fantasias e certezas pulsionais da criança e as evidências e explicações do meio que as contradizem. Esses contínuos fracassos para solucionar o enigma levam a tarefa de pesquisa a ser desestimada e esquecida. Freud observa que "essas hesitações e dúvidas tornam-se, entretanto, o protótipo de todo o seu trabalho intelectual posterior aplicado à solução de problema, tendo esse primeiro fracasso um efeito limitante sobre todo o futuro da criança" (Freud, 1908/1996, p. 198).

O pai da psicanálise argumenta que a curiosidade das crianças se manifesta no prazer de realizar perguntas contínuas aos adultos, que logo após compreendem "que todas essas perguntas não passam de meros circunlóquios que nunca cessam, pois a criança os está usando em substituição àquela única pergunta que nunca faz" (Freud 1910/1996, p. 86, o itálico é do autor). As pesquisas sexuais das que fala Freud contornam o problema da origem dos bebês e constituem uma etapa do desenvolvimento das crianças como forma de controle da chegada de um irmão. Essas pesquisas são o pontapé inicial para a independência intelectual porque a criança não aceita passivamente as explicações fabuladas dos adultos e muitas vezes sentem decepção pelas omissões dos pais a esse respeito. Nas suas palavras:

eles investigam por conta própria, adivinham a presença do bebê dentro do corpo de sua mãe e, seguindo impulsos de sua própria sexualidade, teorizam tudo: a origem do bebê, atribuindo-a à comida; o seu nascimento, explicando-o pelas vias intestinais, e sobre a parte obscura que cabe ao pai (ibid, p. 87).

Essas tentativas de trabalho intelectual autônomo atravessam um período de "enérgica repressão sexual" (ibid, p. 87). As repercussões das teorias sexuais infantis continuam logo após o final das pesquisas sexuais, o que faz com que elas resultem importantes também na clínica. Segundo Freud $(1905,1910)$, o fracasso de pesquisa autônoma pode ter "um efeito paralisante e deprimente pela vida afora" e a renúncia do pequeno investigador às vezes deixa prejuízos permanentes para a pulsão de saber. Nessa linha, na perspectiva piagetiana, o conflito cognitivo é o que desequilibra as estruturas do pensamento permitindo assim a criação de novidades. Portanto, uma negação ou insensibilidade crônica da perturbação pode gerar um retardamento nesse desenvolvimento, tornando-se defesa sintomática.

Para explicar sua influência no desenvolvimento intelectual posterior, Freud postula três destinos do desejo de saber sexual. Esses destinos vão depender da relação que a criança construiu com os interesses sexuais. Um deles consiste na inibição da curiosidade e uma atividade intelectual limitada. Segundo Freud esse processo pode ser reforçado pela influência da educação que efetua uma inibição religiosa do pensamento. Um segundo percurso do 
desenvolvimento intelectual é o que resiste à repressão sexual dominante. Portanto, a inteligência se torna mais forte e as atividades sexuais suprimidas emergem do inconsciente na forma de uma "preocupação pesquisadora compulsiva". O pensamento é sexualizado e as operações intelectuais carregam o prazer e a ansiedade próprios dos processos sexuais. $\mathrm{O}$ terceiro tipo de desenvolvimento (e o mais raro para Freud) escapa dos dois destinos anteriores: da inibição e da compulsão do pensamento. A libido escapa da repressão, sendo sublimada sem qualidade neurótica. A pulsão pode agir a serviço do interesse intelectual.

A partir de um enfoque mais antropológico e arqueológico, Freud se remonta a como os primeiros homens tentaram explicar os fenômenos do nascimento e da fecundação a partir de diversas construções míticas. Segundo a nota introdutória de James Strachey para a obra Totem e Tabu (1913/1989) a noção de mitos endopsíquicos é mencionada por Freud na Carta 78 a Fliess quando alude a uma psicomitologia que contemplaria reflexões da psiquê interior sobre temas como a vida depois da morte e a imortalidade. No Prólogo, Freud (ibid, p. 8) afirma que o objetivo da obra é tentar "coligir o sentido originário do totemismo desde as suas impressões infantis e os assomos que dele afloram no desenvolvimento das nossas próprias crianças", admitindo que o tema a tratar resulta "uma realidade de difícil reconstrução".

O tabu encerra o mítico por excelência: a pergunta pela origem e o impossível de saber ficará para sempre na ordem do enigma. Portanto, Freud desenvolve uma gênese mítica na impossibilidade de chegar ao ponto de origem (mito da horda primitiva). No terceiro ensaio dessa obra sugere que o animismo, a magia e a onipotência dos pensamentos são característicos dos povos primitivos, mas também do pensamento infantil, e que as brincadeiras simbólicas das crianças são comparáveis à figuração do desejo mediante alucinações motoras dos primitivos adultos. Em 1908, Freud já tinha afirmado que conhecer o modo como as crianças concebem as teorias sexuais ajuda a elucidar mitos e contos de fada.

Segundo o Dicionário Aurélio (Ferreira, 1993, p. 367) o mito se define como uma “narrativa simbólica que encerra uma verdade cuja memória se perdeu no tempo". Ou seja, constitui uma invenção discursiva imaginária que, ao tentar dar conta do problema da origem, gira em torno daquilo do que não se pode falar, do impossível, enfim, do desconhecimento. Em Totem e Tabu, Freud (1913/1989) assinala que no curso da história, três grandes cosmovisões do mundo produziram três grandes sistemas de pensamento: o animista (mitológico), o religioso e o científico. Esses três sistemas permitiriam estabelecer uma correspondência respectiva com três etapas do desenvolvimento da libido: o narcisismo, o achado de objeto ligado ao casal paternal e o estado de maturidade do indivíduo que procura 
seu objeto no mundo exterior. Freud (1905/1996) distingue a libido do objeto da libido do ego ou narcísica da seguinte forma:

\begin{abstract}
A libido narcísica ou do ego parece-nos ser o grande reservatório de onde partem as catexias de objeto e no qual elas voltam a ser recolhidas, e a catexia libidinosa narcísica do ego se nos afigura como o estado originário realizado na primeira infância, que é apenas encoberto pelas emissões posteriores de libido, mas no fundo se conserva por trás delas (p. 206).
\end{abstract}

O desenvolvimento da criança é progressivo. Na perspectiva psicanalítica a sucessão das fases sempre deixa resíduos (objetos de fixação) das anteriores. Na perspectiva piagetiana, os estágios precedentes constituem a base dos níveis mais elevados de estruturação cognitiva. Isso explicaria porque as teorias sexuais infantis não acabam com seus efeitos aos 5 anos ou no final da fase fálica, mas continuam se resignificando e se recriando. Cognitivamente, talvez, até atingir a capacidade de operar formalmente. Mas afetivamente, ou pelo menos na perspectiva da psicanálise, pode ser uma tarefa para a vida toda.

Segundo Freud, o Ego deve enfrentar as exigências de suas três relações de dependência: da realidade, do Id e do Superego, preservando sua organização. Em Esboço da psicanálise (1938/1974) lembra que o Ego da criança é ainda débil, imaturo e incapaz de resistência para lidar com tarefas que posteriormente será capaz de enfrentar. Uma das tarefas a enfrentar durante a fase fálica (entre 3 e 5 anos em média) é a tentativa de resolução do enigma do nascimento. Essa tarefa de investigação, para Freud, está vinculada à pulsão de saber, que trabalha com energia escopofílica (relacionada com a atividade de olhar e adquirir conhecimento). Ela também é definida como pulsão de investigar (ou epistemológica) e a sua atividade se define como uma forma sublimada de dominação. Não forma parte dos componentes pulsionais fundamentais nem pode ser subordinada à sexualidade, mas "recai, em forma insuspeitadamente precoce e com inesperada intensidade, sobre os problemas sexuais, e ainda talvez é acordada por estes" (Freud, 1905/1996, p. 183). A impossibilidade da compreensão total do ato sexual e do nascimento se deve à organização sexual infantil ainda atrasada no papel do sêmen e na existência da vagina. As teorias sexuais infantis desse período são definidas por Freud como "reflexos da própria constituição sexual da criança" e acrescenta que "os esforços do pequeno investigador são geralmente infrutíferos e acabam numa renúncia que não rara vez deixa como seqüela um deterioro permanente da pulsão de saber" (ibid, p. 185-186).

Assim, na perspectiva freudiana, as teorias sexuais infantis são típicas porque não surgem de um ato mental arbitrário ou de impressões casuais, mas das necessidades da constituição psicossexual da criança. O "fragmento de verdade" que elas possuem, provém 
dos componentes pulsionais sexuais do organismo da criança. Freud assinala que "apesar de seus erros grotescos, testemunham uma maior compreensão dos processos sexuais, do que se pretenderia de seus criadores" e agrega que elas inauguram um novo modo de se relacionar com o conhecimento: "a investigação sexual desses primeiros anos da infância é sempre feita na solidão; significa um primeiro passo para a orientação autônoma no mundo" (Freud, 1905/1996, p. 185-6).

Em resumo, as teorias são concebidas sob a influência dos componentes da pulsão sexual. Diferentemente de Piaget, interessado pelas formas, a ênfase de Freud é posta nos conteúdos das teorias. Porém, seria possível realizar uma análise mais formal a partir da sua concepção de aparelho psíquico, por um lado, e das fases do desenvolvimento psicossexual ou libidinal, por outro (ambos os temas já apresentados anteriormente). Sendo que o acaso não é tolerado pela criança deste período, pode-se pensar a solução ao enigma da origem dos bebês e das diferenças sexuais como uma imposição produto do desenvolvimento correlato e simultâneo da estrutura cognitiva e da libido.

Em 1908, no texto Sobre as teorias sexuais infantis, Freud propõe o conteúdo das teorias. A primeira teoria, denominada falocêntrica, deriva das diferenças entre os sexos. A criança atribui a todos, inclusive às mulheres e até aos objetos, a posse de um pênis. Isso é conseqüência do que o menino sabe a partir de seu próprio corpo. As meninas também compartilham esse interesse que logo será seguido pela inveja. O pênis é a principal zona erógena e objeto sexual auto-erótico. Segundo Freud, o clitóris da mulher é um órgão homólogo que durante a infância funciona como um pequeno pênis. Essa é a parte de verdade que o autor atribui a esta primeira teoria sexual infantil: o clitóris é sede de excitações durante a infância, conferindo assim um caráter masculino à atividade sexual da menina. Em relação à origem dos bebês o pênis é a chave do mistério para o papel do pai na fecundação, e será alvo de pesquisas quando o mero fato de que o bebê se localiza no corpo da mãe já não resulte suficiente. Para Freud, de maneira similar a Piaget, o próximo passo da criança será se perguntar como ele chega lá dentro? Porém, a tarefa de investigação fica interrompida nesse ponto pela impossibilidade de descobrir a existência da vagina já que a criança sustenta a teoria de que sua mãe também tem pênis (Freud, 1908/1996).

Em 1905, Freud afirmava que a diferença entre a sexualidade da infância e a do adulto estava na primazia do serviço da reprodução, ou seja, na incapacidade das crianças para subordinar as pulsões parciais à primazia dos genitais. Porém, em 1923 afirma que há muitas mais aproximações entre as duas. Ademais da escolha de objeto, nas duas "o interesse nos genitais e a sua atividade adquire uma significação dominante" (Freud, 1905/1996, p. 158). 
Contudo, a maior diferença entre ambas as sexualidades é que as crianças apenas consideram um órgão genital: o masculino. Assim, há primazia do falo e não dos órgãos genitais. Vale assinalar que também neste texto (como em vários da sua obra) Freud antecipa que só lhe é possível descrever a situação dos meninos porque não conhece os processos próprios das meninas. A respeito do falo afirma que "a força impulsiva que essa porção masculina do corpo desenvolverá posteriormente na puberdade, se expressa nesse período da vida, sobretudo como premência a investigar, como curiosidade sexual" (ibidem). Segundo Freud, muitos dos atos de exibicionismo e agressão cometidos pelas crianças são “experimentos empreendidos a serviço da pesquisa sexual” (ibid, p. 159). Logo após dessa distorção de que nas meninas "o pênis vai crescer', lentamente as crianças

chegam à conclusão emocionalmente significativa de que, afinal das contas, o pênis pelo menos estivera lá, antes, e fora retirado depois. A falta de pênis é vista como resultado da castração e, agora, a criança se defronta com a tarefa de chegar a um acordo com a castração em relação a si própria (ibidem).

A castração deve ser entendida como um dano narcísico pela perda (também experimentada na perda do seio e das fezes). Mas a castração propriamente dita se instaura em relação à perda do órgão genital masculino. Portanto, ela constitui um elemento a mais para pensar a gradual dissolução do narcisismo da criança e sua adaptação ao princípio de realidade como fatores constitutivos da passagem entre a fase fálica e o período de latência do desenvolvimento psicossexual. Apreciações sobre o narcisismo da criança são mencionadas em varias obras freudianas (Totem e tabu, 1913; Introdução ao narcisismo, 1914; A dissolução do complexo de Édipo, 1924; Os dois princípios do funcionamento mental, 1911).

Segundo Freud, o horror às mulheres e a disposição ao homossexualismo derivam dessa convicção final de que as mulheres não possuem pênis. Porém, essa convicção não é rapidamente generalizada, mas passa por distintas pré-concepções, como que só as mulheres desprezíveis não têm pênis enquanto que a mãe da criança e as mulheres respeitadas sim conservariam um. Quando desaparece essa crença das mulheres com pênis? Para responder essa pergunta resulta oportuno lembrar a idéia freudiana da "equação simbólica" pênis = fezes $=$ bebê $=$ presente $=$ dinheiro. A crença cai quando as mães "perdem" o pênis. Esta descoberta ser origina a partir das pesquisas sobre o nascimento dos bebês e da confirmação de que só as mulheres podem parir. Aí, começam a ser construídas "teorias bastante complicadas para explicar a troca do pênis por um bebê". Os órgãos sexuais femininos não são descobertos e a criança imagina que o bebê vive nos intestinos da mãe e sai pelo ânus (Freud, 1923/1996, p. $160)$. 
Em resumo, para Freud durante os estágios do desenvolvimento sexual na infância, se dão algumas transformações em relação à concepção da polaridade sexual adulta:

1. Na organização pré-genital, há uma antítese entre ativo e passivo, e não entre masculino e feminino.

2. Na fase fálica, só existe masculinidade e não feminilidade. A oposição se funda entre possuir o órgão genital masculino ou ser castrado (mas no momento em que a mãe perde o pênis se produz a troca do pênis pelo bebê).

3. Na puberdade, a polaridade sexual coincide com masculino e feminino.

Em linhas gerais, na perspectiva freudiana para a masculinidade se combinam os fatores sujeito, atividade e posse de pênis e para a feminilidade se combinam os fatores objeto e passividade porque a vagina é o lugar de abrigo para o pênis.

A ignorância da vagina leva a uma segunda teoria: a cloacal. A criança acredita que o bebê é expelido em uma evacuação. Para Freud (1908/1996) é uma teoria natural, levando em consideração que resulta válida para muitos animais. Além disso, o nascimento pelo ânus permitiria que os homens também parissem. Posteriormente, a criança acredita que o bebê será retirado do umbigo, ou de um corte na barriga (ao modo de Chapeuzinho Vermelho), porque as crianças mais velhas vão reprimir os componentes sexuais anais condenados por sentimentos de repugnância e vergonha. $\mathrm{O}$ interesse desta teoria para a presente pesquisa radica não só no seu conteúdo, mas especialmente na sua forma. Freud a relaciona com a idéia infantil de que a ingestão de comida pode gerar um bebê (assim como sucede em alguns contos de fada). Assim, a saída do bebê pelo ânus, além de indicar a ignorância da vagina, mostra que a criança encontrou uma solução bem original e inteligente ao problema do nascimento. O bebê sai pelo ânus porque essa é a forma (já conhecida e experimentada pela criança) em que grande quantidade de matéria pode sair do corpo. Ainda mais, se a criança acredita que o bebê se forma com comida, este esquema de assimilação já conhecido (de evacuação) é bem compatível com o problema da saída do bebê da barriga: o que entra pela boca sai pelo ânus.

A terceira das teorias sexuais típicas é a concepção sádica do coito. Pode ser produto da testemunha de uma relação sexual (barulho, posições, etc.). A percepção da criança é incompleta e ela "o encara com um ato imposto violentamente pelo participante mais forte ao mais fraco" (ibid, p. 199). Essa teoria encerra um retorno aos comportamentos cruéis impulsionados pelas excitações do pênis da criança quando refletia sobre a origem dos bebês. A agressividade é vinculada com o método que a própria criança utiliza com seus brinquedos, ou com seus irmãos ou colegas. A isso se acrescenta a possibilidade de que a criança 
testemunhe brigas contínuas entre os pais e manchas de sangue na cama da mãe ou em roupas íntimas que confirmem as suas suspeitas de sadismo (Freud, 1908/1996, p. 198-200).

Outra questão considerada por Freud em relação à origem dos bebês é a representação acerca do casamento. A criança veria nele uma promessa de prazer relacionado com a ausência de pudor. Assim, o autor achou com frequiência a idéia de que os casados urinam um em frente do outro ou que o homem urina na vagina da mulher. Outra representação é que o casamento consiste em se mostrar "o traseiro" sem sentir vergonha. Essas concepções aparecem nos jogos infantis, mas também nos sintomas de doenças neuróticas posteriores, como as fobias (ibid, p. 201).

No entanto, cabe realizar outra distinção explicitada por Freud para o funcionamento do aparelho psíquico das crianças que impede considerá-lo equivalente ao do adulto. Quando o autor tenta explicar o conteúdo do Inconsciente remete a dois momentos. O primeiro, explicado a partir da metáfora da presença de uma população aborígine na mente, representa as possíveis formações mentais herdadas que constituiriam o núcleo do Inconsciente. O segundo se constitui com o que se descarta como inútil durante o desenvolvimento da infância. Assim, para entender a progressão e dissolução das teorias sexuais infantis é preciso considerar a constituição dos sistemas Consciente e Inconsciente, já que para Freud até a puberdade não ocorre "uma divisão acentuada e final entre o conteúdo dos dois sistemas" (Freud 1915/1996, p. 200).

Da necessidade de definir o sujeito do inconsciente da psicanálise surge a pergunta pelas possíveis singularidades de organização do aparelho psíquico das crianças e as tendências predominantes dos processos primários ou secundários. A respeito das crenças sobre a origem dos bebês, essa concepção de sujeito se justifica na seguinte afirmação de Colette Soler:

\footnotetext{
com a evolução dos costumes, a televisão e a educação sexual, revela-se hoje às crianças o que eu chamaria de gestualidade do ato sexual. Há um século viam-se sujeitos que chegavam aos doze anos antes de saber esta gestualidade do ato sexual. Hoje, na escola maternal, todas as crianças a conhecem. Mas isto não muda nada (Soler, 2002, p. 11, o negrito é nosso).
}

Poder-se-ia perguntar a que se refere a autora com a postulação de que todas essas transformações histórico-sociais não mudam nada. A afirmação é provocadora, mas toca a essência do problema abordado neste trabalho. Na perspectiva da psicanálise o sujeito suporta um traumatismo (sexual) estrutural e universal, porém, a tentativa de solução dada a este traumatismo resulta singular para cada sujeito porque, da mesma forma que para Piaget, ele não é concebido como univocamente determinado pelo discurso social que o circunscreve, ainda que o influencie. Exemplo disso são, segundo Soler (2002), as diferenças entre os 
sintomas das histéricas de Freud e os contemporâneos, como os ataques de pânico. Estruturalmente, a formação substitutiva é a mesma, entretanto a sua manifestação muda.

Certamente, no que diz respeito à vigência dos postulados freudianos em relação à sexualidade na atualidade, ela converge em um fato que também é afirmado desde uma perspectiva piagetiana: a percepção visual das diferenças sexuais, as informações da mídia e as explicações dos adultos não evitam que a criança construa suas teorias-crenças contra toda evidência cognitiva. Porém, é importante comentar novamente que para a psicanálise o enigma da sexualidade, pelo seu estatuto estrutural, não será totalmente "resolvido" por chegar a uma fase "adulta" ou genital.

Durante a fase fálica as crianças acham que todas as pessoas têm falo até que percebam o contrário. Mas quando as crianças percebem a diferença sexual como informação visual ou oral na explicação dos adultos, como isso se integra no aparelho psíquico? Seria transformado pela predominância do registro da fantasia e das deformações dos processos primários? Para entender estas questões, é preciso aprofundar a respeito do conceito de angústia como um aspecto inerente ao enigma sobre a sexualidade e a origem.

A psicanalista Colette Soler (2007, p. 147) propõe que quando Freud inverte a idéia da angústia como causa e não como resultado do recalcamento, faz da angústia o que se pode chamar "o afeto do real", afeto de um encontro com o real, no sentido do impossível de suportar, inassimilável à realidade psíquica, ou seja, na ordem do simbólico. O traumático é então definido por Freud como o encontro com um perigo real, explicado como excitação intratável, insuportável. Para Soler, a causa desse excesso de excitação não é assinalada, mas pode se originar de dentro (a nível pulsional) ou de fora; e por isso Freud propõe o termo desamparo ou falta de recursos a partir do qual se reconhecem dois elementos: a quantidade de excitação, por um lado, e as capacidades do sujeito de suportar, por outro, sendo que no desamparo se encontram tanto o real como o sujeito. Dessa forma, indica que a angústia da castração é, para Freud, o fator comum às diversas angústias no registro fenomenológico.

Para entender de que modo repercute essa angústia nas fantasias universais, vale lembrar que Freud enfatiza a especial relação do neurótico (e do homem em geral) com a realidade na tarefa de incorporar o significado psicológico do mundo exterior real-objetivo. Segundo o autor, "os neuróticos afastam-se da realidade por achá-la insuportável, seja no todo ou em parte" (1911/1996, p. 237). Como já foi mencionado, a gênese do pensar se remonta à qualidade de inconsciente e logo após, liga-se a resíduos verbais para permitir a coibição ou adiantamento da descarga motora e para que o aparelho mental consiga tolerar uma tensão aumentada de estímulo (ibid, p. 240). Assim, seguindo a linha do raciocínio freudiano, as 
teorias sexuais das crianças poderiam ser localizadas na origem do pensar, como um modo de tolerar a tensão e adiantar a descarga motora.

Em resumo, interessa ressaltar aqui o fato de que há algo que resiste à mesma percepção, que provoca angústia e tem que ser resolvido. Para resolver as diferenças sexuais se apela então a uma decisão mediadora que não busca a verificação racional como uma hipótese a ser corroborada por métodos científicos. São teorias que se impõem à necessidade da criança de acalmar a sua angústia. A partir da obra A negação sabe-se que "o conteúdo de uma imagem ou idéia recalcada pode irromper na consciência com a condição de que seja negado" porque "a negação é um modo de tomar conhecimento do que está recalcado" (Freud, 1925b/1996, p. 265). Consiste em um cancelamento do recalque e não em uma aceitação do recalcado.

Quando Freud define a dualidade dos sexos como um grande enigma afirma que constitui "um fato supremo para o nosso conhecimento; ele desafia qualquer tentativa de fazêlo remontar a algo mais" (1938/1974, p. 134). Essa tentativa de fazê-lo remontar a algo mais, também entendida, na perspectiva lacaniana, como o que "não cessa de não se inscrever", é um domínio com o qual crianças, adolescentes e adultos terão que lidar como sujeitos do inconsciente.

Em relação ao Complexo de Édipo, a menina constrói a teoria de que ela não tem pênis porque ainda vai crescer e o menino remete ao complexo de castração que ameaça com o corte de seu pênis do mesmo modo em que foi eliminado na menina. Se isto é assim, que ocorre com a percepção dos genitais? Uma criança de 4 anos já teve a experiência de olhar aos seus pais nus, ou a sua irmãzinha, primos, etc., ou seja, a maioria já teve acesso a perceber as diferenças sexuais. A respeito disso, Freud comenta que

\footnotetext{
Sua percepção mostra-lhe que há alguma coisa diferente do que ele possui, mas é incapaz de admitir que o conteúdo de sua percepção é que ele não pode encontrar um pênis na menina. A sua falta parece-lhe uma coisa sinistra e intolerável e procurando uma solução de compromisso chega à conclusão de que as meninas também possuem pênis, somente que é ainda muito pequeno, e que, depois, ele crescerá. Mais tarde, quando percebe que isso não acontece, encontra outra explicação: as meninas também tinham um pênis, mas ele foi cortado e em seu lugar ficou apenas uma ferida (1910/1996, p. 102).
}

A importância que o desenvolvimento da criança sempre teve na psicanálise (tanto em si mesmo como para entender os sintomas adultos) parte da afirmação freudiana de um conflito estrutural nos seres humanos em relação a outras espécies animais. A noção de "infância prolongada" (compartilhada por Piaget) implica que "no espaço de poucos anos, a pequena criatura primitiva deve transformar-se num ser humano civilizado; ela tem que atravessar um 
período imensamente longo de desenvolvimento cultural humano de uma forma abreviada de maneira quase misteriosa" (Freud, 1938/1974, p. 132). Esse período de desenvolvimento tão intenso que para Freud resulta misterioso, é o que em alguns aspectos Piaget conseguiu esclarecer com a sua obra, aprofundando temas que não foram estudados pela psicanálise.

Assim, para concluir, vale destacar que Freud não desestima as dificuldades de tentar abordar o mundo interno do sujeito de maneira global e multideterminada. Nas suas palavras:

não temos maneira de transmitir o conhecimento de um conjunto complicado de acontecimentos simultâneos, a não ser descrevendo-os sucessivamente, e assim acontece que todas as nossas descrições são falhas, de princípio, devido à simplificação unilateral, e têm de esperar até que possam ser suplementadas, elaboradas e corrigidas (Freud, 1938/1974, p. 148).

\subsection{Outros aportes psicanalíticos sobre as teorias sexuais infantis}

Neste item serão apresentadas algumas contribuições de outros autores do campo da psicanálise em relação ao tema da sexualidade e a criança. Serão brevemente apresentadas algumas considerações de Karl Abraham (1913, 1920, 1925) acerca das teorias sexuais infantis e de Winnicott (1982) respeito da criança e o sexo, e dos limites de uma pretendida educação sexual. Serão também comentados alguns aportes mais atuais como os da psicanalista Sophie De Mijolla-Mellor $(2002,2004)$ em relação ao que ela nomeou como "mitos mágico-sexuais" no imaginário da criança, de Bergès e Balbo (2001) e Lemérer (1999), entre outros.

Segundo Abraham (1925/1985), há dois tipos de teorias sexuais infantis: as primárias e as secundárias. As teorias primárias são concebidas pelas crianças com um alto grau de uniformidade e são as primeiras na ordem cronológica em relação às secundárias que são próprias dos anos posteriores da infância e apresentam opiniões que variam muito segundo as influencias exteriores. Além disso, propõe considerar que enquanto durante a fase fálica prevalece a suposição de que a mulher também tem um pênis que está escondido (idéia universal segundo Freud), há outra diferença de tamanho significativa, que consiste no peito feminino em relação ao masculino. Nas palavras do autor,

o sexo masculino é superior respeito ao órgão genital e o feminino é superior em relação ao peito. Este contraste deve se impor por si mesmo à criança, e não deve nos surpreender que transporte suas descobertas de uma região à outra. As teorias sexuais infantis contenderiam assim o resultado desse processo psicológico, e a idéia do grande tamanho e força do pênis feminino estaria determinada, por conseguinte, por a equiparação desse órgão com o peito (Abraham, 1925/1985, p. 258) 
Contudo, se "a superioridade" do pênis masculino é compensado pelo tamanho do peito feminino, como se explica o complexo de castração feminina? Para explicar essa questão é preciso se remeter a outros dos seus aportes acerca das manifestações desse complexo nas meninas e mulheres (Abraham, 1920/1980). Para o autor, a desvantagem que a menina sente em relação ao menino, não encontra causas meramente sociais, como as diferenças de liberdade que se oferecem a meninas e meninos ou as restrições da vida sexual. Responde sim a processos biológicos e fisiológicos que ferem o narcisismo da menina. Ela compara seu corpo com o dos meninos ou irmãos e quer ser como eles. Para Abraham, a menina volta o olhar no pai que é considerado possuidor de uma onipotência criadora que pode outorgar essa parte do corpo que ela não tem e deseja. Esses sonhos de compensação não duram muito tempo: "o princípio do prazer deixa de dominar incondicionalmente os processos psíquicos, começa a adaptação à realidade e com ela, a crítica dos próprios desejos por parte da criança" (Abraham 1920/1980, p. 262). Essa afirmação indicaria que a consciência do próprio corpo e do si mesmo se constrói a partir de um processo dialético, social e autônomo. Para a criança implica se perceber como parte de uma relação social, ou seja, significando ao outro e a si mesmo a partir de uma progressiva descentração, física e psíquica, que lhe permite se autoreconhecer e construir uma imagem do próprio corpo e do Eu.

Em 1913, Abraham escreve um pequeno texto acerca dos efeitos psíquicos produzidos em uma criança de nove anos a partir da observação das relações sexuais entre seus pais. A partir do caso clínico, o autor esclarece que a observação em si mesma não foi o determinante causal do trauma porque previamente a menina já tinha predisposição à neurose. Isso pareceria indicar que Abraham apela ao conceito freudiano já comentado (cf. item 3.2) de "séries complementares" porque para o autor é a predisposição somada à observação da relação sexual o que traz conseqüências psíquicas (predisposição constitucional + vivências acidentais). Disto poderia se concluir que as experiências acidentais do meio são fatores necessários, mas não suficientes para desencadear sintomas neuróticos.

O desenvolvimento psicossexual exige uma adaptação da menina que resulta diferente no menino. Para Abraham (1920/1980), isto é assim porque a menina tem que compensar sua falta de pênis. Ela o consegue desfrutando das suas primeiras sensações genitais a partir das quais seu órgão feminino volta a ter um valor narcisista. Além disso, é compensada a partir do paralelo "fezes $=$ presente $=$ pênis". No caso do menino, em um primeiro período ele considera seus excrementos como parte de seu próprio corpo e o processo de identificação estabelece uma relação entre excrementos e pênis, entendendo que este pode se deslocar de seu próprio corpo. A assimilação das duas idéias é o que gera a sua ansiedade. 
A mesma equação é mantida pela menina, até que se decepciona porque a sua expectativa de ter um pênis não se cumpre. Porém, a saída dessa situação se estrutura a partir da fantasia agregando um elemento à equação: "fezes = presente = pênis = filho". A inveja do pênis se substitui pela envida da posse dos filhos. Assim, na saída do período edípico, e logo após o período de latência, passará a desejar o auxílio de outro objeto amoroso que não seja o pai para satisfazer seu desejo de filho no sentido de um presente substituto do pênis. Ao mesmo tempo, se identifica com a mãe nos impulsos maternais. Para o autor, o desenvolvimento psicossexual da menina enfrenta dificuldades para superar o complexo de castração e muitos eventos biológicos o mantém presente: a idéia primária de ferida na menstruação, a perda da virgindade com perda de sangue e a idéia da cesariana como uma operação sangrenta. Contudo, a libido feminina experimenta grandes alterações até chegar à maturação e com um desenvolvimento "normal" o complexo de castração não causa efeitos perturbadores.

A respeito da fase fálica, Leite (2007, p. 280) explica que o órgão sexual resulta fundamental para a criança que "pressente que seu órgão tem a ver com a questão urgente que a vida lhe impõe resolver". Esclarece, ademais, que na psicanálise existem modalidades de manifestação ou presença subjetiva correlatas a diferentes formas de incidência do corpo (auto-erótico, narcísico e do narcisismo secundário). Pelo fato de que o corpo impulsiona a criança a construir teorias sobre o enigma da sua origem como resposta para acalmar a angústia, Leite considera que as teorias podem ser abordadas estruturalmente como mitos organizadores da subjetividade.

Diante do que foi exposto, pode-se afirmar que tanto na perspectiva piagetiana como na psicanalítica, as respostas do meio social e, especialmente, dos objetos afetivos (pessoas) com os quais a criança compartilha a sua curiosidade sobre os mistérios do corpo e da sua origem, influenciam a construção das crenças sexuais (porém, para ambas, essa influência social é um fator necessário, mas não suficiente na sua construção). Os vínculos das crianças com os adultos poderão se afiançar ou se enfraquecer de acordo com o estilo de resposta que se oferte, mas para além do fator social, há algo que resiste na criança e lhe é próprio: as estruturas da inteligência pré-operatória para a teoria de Piaget, e a prevalência dos processos primários e da fase fálica no desenvolvimento, para a psicanálise. É possível afirmar, então, que tanto para Freud como para Piaget, a criança e suas produções nunca resultam em uma consequiência direta dos pais ou do entorno. Por isso, ambas as propostas teóricas podem ser definidas como interacionistas, contrariamente a uma proposta empirista ou inatista do desenvolvimento. A idéia de "teorias sexuais infantis" regidas pelo princípio de prazer e, 
portanto pelas fantasias, assim como a assimilação mental do problema da origem dos bebês a um pensamento pré-operatório e intuitivo, faz com que nem todo o processo de construção do conhecimento dependa do meio social que envolve a criança. Contudo, o modo de transmissão do conhecimento sobre a sexualidade (na escola, no lar) influencia a qualidade de construção do conhecimento que a criança atinge, mas também o vínculo mantido com os adultos aos quais se dirigem os questionamentos.

A psicanalista argentina Schlemenson (2008), especialista em clínica de crianças com dificuldades de aprendizagem, salienta que ao abordar a construção das perguntas sobre a origem e a socialização de conhecimentos sobre a sexualidade, é necessário considerar que ao transmitir objetos psíquicos representacionais também se transmitem os processos de sua constituição, e as fantasias que organizam, ligam e contextualizam esses objetos. Se a criança pergunta aos adultos acerca de algo que a inquieta e recebe como resposta uma evasão ou desqualificação (porque o conteúdo remete a um aspecto psiquicamente temido pelos adultos), o que se transmite é que perguntar certas coisas resulta perigoso e, portanto, a criança começa a se calar. O sexo e a morte são considerados pela psicanálise como os temas mais difíceis de abordar, ou seja, os denominados enigmas universais.

A respeito de uma possível educação sexual, o psicanalista e pediatra inglês Donald Winnicott (1982) afirma que lições sobre sexo ou uma "instrução sexual organizada" nas escolas não são necessárias já que as crianças pequenas têm, espontaneamente, interesse em aprender coisas sobre a natureza. Nesse processo, o protagonista é a atividade de descoberta do próprio indivíduo. Toda lição sobre sexo empobrece a questão ao abordá-la de fora para dentro, enquanto a experimentação própria tem um potencial de infinita riqueza. Porém, o autor adverte que nas escolas sempre é preciso que haja pessoas que sejam de confiança para as crianças, que ofereçam uma instrução biológica de qualidade e um meio emocionalmente sólido e constante.

Em relação ao jogo simbólico, Winnicott sustenta que as brincadeiras infantis são enriquecidas pelas idéias e simbolismos sexuais e que uma forte inibição sexual pode se seguir de uma inibição lúdica. Ao abordar o tema da "brincadeira sexual" o autor assinala a importância de distinguir a excitação sexual e o desempenho de fantasias sexuais. As brincadeiras sexuais com excitação corporal são casos pouco freqüentes, segundo o autor, porém todas as excitações físicas têm acompanhamento ideativo.

Os aportes de Mijolla-Mellor (2002, 2004) sobre os "mitos sexuais infantis" estão em íntima relação com a abordagem das teorias sexuais infantis freudianas como "mitos endopsíquicos" (cf. item 3.5) e com a afirmação piagetiana de que o estilo de produção mítica 
constitui um traço saliente no desenvolvimento das crenças artificialistas. Na linha das produções míticas, a psicanalista propõe um diálogo entre a psicanálise e as perspectivas mitológica e antropológica (mas sem recorrer aos arquétipos de Jung). De acordo com a autora, pode-se afirmar que a psicanálise não é dissociável da mitologia sempre considerada por Freud a partir da literatura ou da antropologia. Contudo, não se trata de aplicar o método psicanalítico ao material coletado pelos antropólogos, mas de propiciar um diálogo de dois discursos permitindo encontros e questionamentos recíprocos, cada um conservando a sua especificidade.

Mijolla-Mellor (2002) afirma que o mito (que tem o enigma como objeto por excelência) permite à criança acalmar a angústia e dar resposta a sua necessidade estrutural de causalidade quando ela perde o sentido das evidências primárias (como o laço de amor aos pais) e começa o processo de abandono do registro do imediato e de delimitação do interno e externo. Assim, a função do mito seria uma tentativa de reencontro da dimensão de um tempo primordial. Os "mitos sexuais infantis" (também infiltrados nas brincadeiras) são o resultado da onipotência de pensamento. Para as crianças, esses mitos têm uma utilidade específica como modo de demanda à função do pensar de prazeres e respostas que a realidade não lhe dá. A magia presente nos jogos e mitos emerge na tentativa de reproduzir o que os pais fazem no ato sexual, ato ao qual são ligados os mistérios da vida e da morte. Dessa forma, o mito tem por função "vestir" a morte com imagens e jogos para que se torne aceitável. Portanto, os pesadelos, os animais monstruosos nos desenhos e outras imagens são tentativas de combate para figurar a dupla "vida-morte" que constitui o fundo da questão da origem.

O trabalho de Mijolla-Mellor contém outros pontos que merecem destaque. Por um lado, apresenta elementos mais próximos aos de Piaget para entender as crenças sobre a origem dos bebês. Um deles é a afirmação de uma "necessidade estrutural de causalidade" e do aspecto universal da crença como constitucional ao ser humano, pontos que resultam similares à noção de finalismo piagetiano. Por outro lado, a autora utiliza as noções de onipotência do pensamento, desequilíbrio, necessidade de palavras mágicas e o progressivo desprendimento do registro do imediato que são dimensões também desenvolvidas por Piaget. No entanto, além disso, o objetivo da autora foi ampliar o conceito freudiano de teorias sexuais infantis e diferenciar seus estratos para superar "sua rigidez como teorias típicas".

Os mitos sexuais das crianças são definidos pela autora como intuições que tem valor de certeza. Não se manifestam à maneira hipotética dedutiva própria da teoria, mas de forma quase de oráculo, com palavras mágico-sexuais misteriosas (Mijolla-Mellor, 2002, p 63). Essa preferência pelo termo "mitos" em detrimento de "teorias" coincide, em parte, com a 
justificativa da eleição do termo piagetiano "crenças" em vez de "teorias sexuais infantis" desta pesquisa. Interessa também ressaltar que para a autora os mitos, os contos e as teorias sexuais infantis compartilham não somente o enigma da origem, mas também revelam uma marcha de pensamento comum que se aproxima mais do mito e da magia que da teoria porque tem valor de certeza. A necessidade de palavras mágicas (tema abordado por Piaget em 1926) se evidencia nas crianças de 4 a 8 anos. Nessa faixa etária, as palavras têm eficácia mágica. Quais são as suas principais características? Elas estão mais próximas da sensação, são secretas e tem valor identificatório, porque não são de uso comum, mas próprias da criança (ou seja, que funcionam ao modo do símbolo e não do signo).

A pergunta pela origem dos bebês contém muitas outras questões existenciais e afetivas, e nela subjaz a dificuldade de lidar com o aleatório e o determinismo físico. Segundo a autora, o tema da vinda ao mundo desequilibraria o narcisismo da criança quando pode remeter a um ato procriador resultado do acaso. Assim, a pergunta principal não seria como você me fez, mas você me desejou? (Mijolla-Mellor 2002, p. 69). Além disso, a questão sobre a origem também implica uma relativização e reposicionamento da criança em um contexto temporal finito. Nas palavras da autora:

A representação de não ter existido sempre e de não estar seguro de existir para sempre,
junto à descoberta da não evidencia do laço de amor, cria na criança um equivalente da
castração no domínio da identidade. E aí que é preciso ver o ponto de partida da
necessidade de causalidade para restabelecer o sentido que foi desmoronado (ibid, p. $62, o$
negrito é nosso).

Em uma linha mais clínica, Bergès e Balbo (2001) reiteram a idéia freudiana de que as teorias sexuais infantis possuem um fragmento de verdade porque não são inventadas, mas é o corpo erotizado que as impulsiona, um corpo que, nas palavras dos autores, constitui um "teatro do desconhecimento". Entre as suas funções, assinalam a possibilidade de controle e domínio da realidade para afrontar a angústia. A importância das teorias sexuais infantis na clínica permanece vigente porque sua singularidade consiste em ser "uma teoria pela qual a sexualidade dos pais está sob o controle da criança que se torna assim, filho único" (ibid, p. 10).

Outra função das teorias é a de antecipação, já que é preciso partir de um saber inconsciente "que antecipa e precede o saber sobre o qual a criança torna-se curiosa e que ela se autoriza a adquirir a partir de uma teoria sexual infantil que é domínio e a permissão" (ibid, p. 121). Os autores assinalam também que a negação/desconhecimento constitui um processo primário e a superação dessa negação implicaria uma passagem "da certeza absoluta à dúvida". Nas suas palavras, na atividade do pensamento "é mesmo preciso que tenhamos 
algumas dúvidas em certos momentos, para continuar a pensar com os outros; do contrário, se está em uma certeza absoluta, sem condição nem limite" (Bergès \& Balbo, 2001, p. 20). Essas afirmações corroboram as características, já assinaladas, da passagem entre a crença como convicção egocêntrica à necessidade provar e argumentar com critérios objetivos no plano da discussão com outros.

Lemèrer (1999) destaca algumas idéias freudianas em relação às pesquisas sobre a origem do bebê. Em primeiro lugar, que a pesquisa é uma atividade sexual da criança, estimulada pelo desejo sexual de saber. Esse desejo se origina do gozo sexual dos pais, do qual ela está excluída. O desejo de saber tem outras traduções assinaladas pela autora: curiosidade intelectual, avidez de saber. Segundo Lemèrer, assim como o onanismo infantil é insatisfatório por sua própria natureza, a questão da procriação gera uma "insaciável sede de saber”. Porém, qualquer que seja a informação recebida dos adultos (evasão, informação mítica ou cientifica), sempre será insatisfatória de estrutura "pois é inteiramente impossível a um sujeito responder por seu ser sexuado, responder como sujeito do sexo, como sujeito da procriação" (ibid. p. 14). Para a autora, as explicações dos adultos rodeiam e escavam essa falta estrutural em relação ao saber sexual. Dessa falta, a criança faz "o lugar de um saber proibido, um saber que os adultos guardam para si”. A criança concebe aos adultos como fontes de saber e se sente excluída, o qual suscita "um desejo sexual de saber que precipita a criança em investigações pessoais onde se elaboram as teorias sexuais infantis” (ibid, p. 15). A atividade intelectual da criança é estimulada e fica a serviço desse desejo, experiência que constitui segundo Freud, a primeira tentativa de autonomia intelectual.

O desejo de saber sexual é um desejo sexual de saber, e "o desejo de saber só se exerce na margem de liberdade que o sujeito tem em relação à autoridade, à segurança e ao amor que o Outro representa. Essa margem de liberdade é inteiramente variável conforme os sujeitos" (Lemèrer, 1999, p. 16). Segundo a autora, essa margem permite o desenvolvimento ou a inibição do desejo de saber em distintos níveis, porque Freud mostra que essa primeira tentativa de independência e autonomia intelectual é motivo para o primeiro conflito psíquico. Vale lembrar aqui a noção de "preferência pulsional" proposta por Freud (1908/1996), que destaca o fato de que as teorias sexuais são elaboradas na solidão porque revelam o saber da pulsão, não provém do acaso das impressões ou de uma decisão psíquica, mas da pulsão sexual.

Similarmente a Piaget, a autora destaca que, para Freud, nem as informações dos adultos nem os acontecimentos contingentes da vida têm um lugar determinante nas construções das crianças. $\mathrm{O}$ fragmento de verdade das teorias que a criança inventa tem sua 
origem nos componentes da pulsão sexual. Em síntese, as teorias sexuais infantis levam a um conflito psíquico que desembocará no seu recalcamento.

Segundo Voltolini (2009) ainda que as crianças recebam esclarecimentos sobre a sexualidade preferem ficar apegadas às suas próprias teorias elaboradas a partir da observação. Essas teorias resistem o que logo após serão forçadas a elaborar, embora nunca de maneira completa. Para o autor, a dúvida comporta uma angústia que se alivia provisoriamente com soluções que futuramente portarão novos enigmas. A dificuldade de lidar com o aleatório e o desejo de impedir que o acaso exista não é exclusivo da infância. Constitui uma característica do homem em geral e por isso nunca se abandona a fase dos porquês. A respeito da inteligência e afetividade, Voltolini (2009) afirma que para Freud:

o pensamento não é só afetado eventualmente, como crêem os adeptos da clivagem emocional/racional, senão que não há pensamento que não seja afetado e que esta afetação não é boa nem má, em princípio, mas que ela é característica do pensamento humano (p. 3).

Como já for mencionado (cf. item 3.5) Freud entende que as teorias sexuais infantis constituem uma forma de controle construída a partir da possibilidade latente ou concreta da chegada de um irmão. Segundo Voltolini, (2009) o ser humano se direciona seguindo um império das preferências. O "império das preferências" é o que em Freud mostra que o ser humano é desejante por estrutura. Assim, o autor destaca que na negação da existência do óvulo e do espermatozóide, as crianças negam a relação sexual e especialmente a penetração.

Essa negação da existência do espermatozóide e do óvulo é o que, para Voltolini (2009), as universaliza ainda que existam infinitas versões singulares. A origem da própria vida constitui um enigma eterno porque nele se constata que a existência é produto do desejo de alguém e não da própria escolha. Além disso, a negação da percepção dos órgãos sexuais é um modo de evitar a castração. Essa tentativa será o motor para teorizar e assim apagar as diferenças. Como pensam as crianças na perspectiva da psicanálise? A partir de um pensar que surge do "corpo todo", corpo que participa na forma e o conteúdo do pensamento infantil:

Estes objetos, inicialmente corporais, que Freud destacou como sendo: a boca, o ânus e os órgãos genitais não cessam de fornecer o molde e no caso das crianças também o conteúdo de suas formulações. O que Freud está dizendo, bem entendido, é que não pensamos com o cérebro, mas com o corpo todo, ou melhor, que o corpo participa da atividade de pensar. Se as crianças não incluem em suas teorias o espermatozóide e o óvulo é, em parte, porque não possuem a experiência disso em sua própria erotização do corpo (Voltolini, 2009, p. 9).

Esse pensar a partir do corpo todo está em conformidade com a definiçãa freudiana de pulsão (cf. item 1.2 Justificativa) como conceito limite entre o psíquico e somático. Para Freud, a pulsão é o representante psíquico dos estímulos do organismo que "alcançam a mente": a mente é exigida pelo corpo. Portanto o pensamento da criança e em consequiência 
suas produções semióticas são sobredeterminadas pelas suas pulsões e pela sua forma de raciocínio. Em resumo, segundo Voltolini, a construção das teorias sexuais infantis, é uma questão de conveniência para a criança. Não somente como um produto do interesse "prático" de impedir o nascimento de um irmão, mas especialmente porque esse evento desagradável confirma que o mundo não é regulado por ela.

Entender que um indivíduo não regula o mundo, porque ele se organiza a partir de leis físicas e circunstâncias que excedem a nossa existência, é para Piaget, uma conquista, produto de um contínuo processo de descentração. O desenvolvimento dessa descentração (que traz repercussões afetivas e cognitivas) se consolida ao mesmo tempo em que o egocentrismo ameniza sua preponderância. A prevalência do egocentrismo do pensamento pré-operatório seria o contraponto de um pensamento descentrado. Porém, como já foi mencionado, o egocentrismo não é sinônimo de traço infantil, já que pode continuar se manifestando nos adultos. Por isso é que o egocentrismo é um conceito amplo que deve ser abordado no contexto da dialética cognição-afetividade. 


\section{O DIÁLOGO ENTRE AS TEORIAS PIAGETIANA E FREUDIANA}

Para abordar o estudo das crenças sobre a origem dos bebês a partir de relações entre conceitos piagetianos e freudianos, vale mencionar algumas divergências e convergências básicas entre as duas teorias, no que diz respeito à concepção de sujeito, ao desenvolvimento infantil intelectual e afetivo, aos interesses e objetivos de estudo e às metodologias de ambos os autores. De modo geral, é possível afirmar que enquanto Piaget tem como objetivo estudar como o sujeito humano passa de um estado de menor conhecimento a outro de maior conhecimento, Freud estuda a etiologia das neuroses e de outras doenças mentais. Piaget não se interessa pelos estados patológicos e focaliza o desenvolvimento do ser humano procurando regularidades e formas comuns na construção do conhecimento. Para Freud, o foco de interesse na constituição do aparelho psíquico se centra nos processos inconscientes e especialmente nos sintomas e outras formações do inconsciente como sonhos, atos falhos e esquecimentos, subestimados até então como "resíduos" psíquicos.

Piaget trabalhou com o método clínico a partir da realização de numerosas entrevistas semi-estruturadas e provas operatórias com crianças e adolescentes, o que lhe permitiu observar padrões comuns de respostas e ações e inferir a presença de estruturas mentais. Freud utilizou principalmente o método interpretativo a partir da associação livre dos pacientes e priorizou a análise de alguns casos clínicos paradigmáticos (Homem dos lobos, Homem dos Ratos, Dora, o pequeno Hans, entre outros). Nessa linha, outra divergência importante é que, à exceção do caso do pequeno Hans e algumas observações (no geral realizadas com seus netos e filhos ou recebidas de colaboradores), Freud postulou o desenvolvimento psicossexual das crianças especialmente a partir da clínica com adultos, enquanto Piaget sempre trabalhou diretamente com as crianças. Abraham afirma que, a não ser por seus resultados, os processos de desenvolvimento psicossexual das crianças são dificilmente accessíveis à observação direta: porém, segundo o autor, "não pode assombrar a ninguém que tenha percebido através de seu próprio trabalho psicanalítico em que amplo grau as teorias de Freud são o resultado da observação direta, e quão longe estão da especulação ociosa" (Abraham, 1916/1985, p. 23).

Em resumo, e para além da questão da observação, pode-se afirmar que se Piaget focalizou o registro do desenvolvimento ontogenético para procurar as regularidades na construção progressiva do conhecimento, Freud se centrou na etiologia das neuroses e na construção de um dispositivo que permitisse curar os sintomas dos pacientes. Para tanto, este 
último também precisou elaborar uma teoria que explicasse a sua constituição, partindo de uma concepção singular de desenvolvimento psicossexual.

A respeito das convergências entre os autores, de acordo com Colette Chiland (1993), tanto para Freud como para Piaget, o indivíduo não é uma tábula rasa na qual se imprimem as suas experiências, mas é a partir das suas potencialidades primeiras que o sujeito as organiza. Estas potencialidades são, para Piaget, os elementos biológicos (reflexos) a partir dos quais se constroem os esquemas sensório-motores, e para Freud, a base orgânica na qual se apóiam as pulsões que impelem ações e engendram fantasias inconscientes. Para ambos, as fronteiras entre o Eu e o não-Eu devem ser construídas, não sendo representadas de imediato. Além disso, os dois autores também consideram que o estudo do desenvolvimento da criança esclarece o do adulto.

Ambas as teorias compartilham o fato de não terem se preocupado em definir limites entre o normal e o anormal. Para Piaget há respostas qualitativamente diversas e por isso ele estuda a progressão genética do conhecimento sem focar idades nem diagnosticar índices de inteligência (como o coeficiente intelectual). Ainda que universalistas, tanto Freud como Piaget admitem variações segundo as características sociais do contexto no qual o sujeito interage. Nessa linha, as respostas coletadas nesta pesquisa mostram níveis de desenvolvimento e não crenças normais ou anormais, adequadas ou inadequadas. Como já foi mencionado, mesmo que a psicanálise tenha se ocupado da psicopatologia, é possível afirmar que, em contrapartida, não se preocupou em definir um padrão de normalidade humana. Em seus estudos sobre o caráter, Abraham faz uma afirmação que bem poderia ser aplicada em um estudo piagetiano que pesquisasse o nível de pensamento lógico atingido por um sujeito:

\footnotetext{
Não é nossa intenção dizer o que é exatamente um caráter "normal". A psicanálise nunca estabeleceu normas deste tipo, mas se contenta em verificar fatos psicológicos. Comprovase simplesmente até onde tem conseguido chegar uma pessoa, na linha de desenvolvimento desde a primeira etapa até a última, na estrutura do seu caráter (Abraham, 1925/1980, p. 106).
}

Como os estágios piagetianos, as fases mais avançadas da formação do caráter também estão edificadas sobre as etapas anteriores de seu desenvolvimento e absorvem seus elementos essenciais (integrando também o complexo de Édipo nesse processo).

Outra convergência que deriva da anterior é o caráter integrativo dos períodos da inteligência e das fases psicossexuais. As respostas das crianças mais velhas reorganizam e resignificam os elementos assimilados na etapa anterior, para estabelecer novas coordenações da informação. Todo desenvolvimento é integrador, portanto não se começa do zero em cada etapa, e isso é sustentado tanto por Piaget como pela psicanálise. Abraham explica que a etapa 
final da organização do caráter "mostra em todas as partes traços de sua associação com as fases precedentes. Toma delas tudo o que conduza a uma relação favorável entre o indivíduo e seus objetos" (Abraham, 1925/1985, p. 111).

Esta característica subjaz também ao desenvolvimento do egocentrismo e do princípio de prazer, que para ambos os corpos teóricos progressivamente diminuem a sua prevalência e nunca desaparecem totalmente, permanecendo sempre relativos em todos os períodos do desenvolvimento. $\mathrm{O}$ egocentrismo que prevalece nas crianças do período pré-operatório se ameniza no pensamento operatório, mas não se extingue, já que permanece presente inclusive nos adultos em maior ou menor medida. Com o narcisismo sucede algo similar. Segundo Abraham:

\footnotetext{
Nas primeiras etapas, seu caráter estava ainda governado em ampla medida pelos impulsos narcisistas. E não pode ser negado que em sua etapa definitiva contém ainda certa proporção de tais impulsos. A observação nos ensina que nenhuma etapa evolutiva, cada uma das quais tem base orgânica própria, nunca é completamente superada ou reprimida. Pelo contrário, cada novo produto do desenvolvimento possui características derivadas da história anterior. Não obstante, ainda que em alguma medida se conservem os signos primitivos do amor a si mesmo, podemos dizer que a etapa final da formação do caráter é relativamente não narcisista (ibid, p. 112, a cursiva é do autor).
}

De maneira similar ao inconsciente da psicanálise, as estruturas cognitivas constituem a chave para entender a psicogênese porque são elas as que dirigem o pensamento do indivíduo que ignora sua existência. Os grandes construtos "aparelho psíquico" e "estruturas cognitivas" não são anatomicamente localizáveis, mas postulados a partir de seus efeitos nas condutas. Porém, em ambos se admite a importância da biologia como um fator influente em ditos construtos. Isso se observa claramente na definição freudiana de pulsão como conceito limite entre o psíquico e o somático (cf. item 1.2 Justificativa). Na percepção de Piaget (1967/1980, p. 19):

Fica biologicamente excluída a possibilidade de considerar a organização dos esquemas de ação como independente de todo fator endógeno (...) as percepções e os comportamentos adquiridos, até as variedades superiores da inteligência operatória, nem por isso deixam de constituir, sob forma mais flexível, a manifestação das possibilidades ou das normas de reação, mas funcionais, da estrutura anátomo-fisiológica da espécie.

No texto Inconsciente afetivo e Inconsciente cognitivo, de 1970, Piaget explica que as estruturas cognitivas determinam não somente o que o sujeito é capaz ou incapaz de fazer (logo, a extensão e os limites de sua capacidade de resolver problemas), mas ainda o que é obrigado a fazer (logo, as ligações lógicas necessárias que se impõem a seu pensamento). Por conseguinte, na perspectiva piagetiana o homem também não é "dono e senhor da sua própria casa". A estrutura não se reduz ao conteúdo consciente do pensamento, pois ela é o que impõe “certas formas mais do que outras". O conjunto das estruturas desconhecidas pelo sujeito, 
exceto em seus resultados, é denominado por Piaget como "inconsciente cognitivo". A assimilação do mundo, entendida como uma digestão mental, é um processo inconsciente, do qual se tem notícias apenas em suas manifestações:

Numa palavra, a estrutura cognitiva é o sistema das conexões que o indivíduo pode e deve
utilizar e não se reduz absolutamente ao conteúdo de seu pensamento consciente, pois é o
que lhe impõe certas formas mais do que outras, e isso segundo níveis sucessivos de
desenvolvimento cuja fonte inconsciente remonta até as coordenações nervosas e orgânicas
(Piaget, 1964/1975, p. 227)

Nesse sentido, para Freud, o desenvolvimento progressivo do Ego também pode remontar até bases orgânicas. $O$ inconsciente freudiano inaugura uma concepção de ser humano em grande parte influenciado por forças das quais ele não é consciente e que, portanto, escapam a seu total controle.

Em resumo, para o presente trabalho a existência de formas e mecanismos psíquicos típicos no desenvolvimento das crianças constitui o ponto de convergência mais relevante. Para a psicanálise, os processos primários e secundários do aparelho psíquico e os conflitos abordados por Freud como parte constitutiva do desenvolvimento psicossexual, têm caráter universal. As fantasias inconscientes são "variações individuais sobre temas comuns a todos os homens e que pertencem à estrutura do ser humano" (Chiland, 1993, p. 34). Piaget não defende a hipótese de uma possível "natureza humana", mas postula a existência de invariantes funcionais e uma ordem dos estágios independente da personalidade do sujeito (De La Taille, 1994).

A partir do objeto de estudo desta pesquisa, outra convergência merece ser ressaltada. Em ambas as teorias afetividade e cognição constituem relações recíprocas e estão sempre presentes nas condutas. Ambos os aspectos da ação humana são correlatos, convergentes e possuem múltiplas correspondências ao longo do desenvolvimento. Conforme afirma Piaget (1964/1975), a afetividade e as funções intelectuais são "dois aspectos indissociáveis de cada ato: em toda conduta, em efeito, os móveis e o dinamismo energético se devem à afetividade, enquanto que as técnicas e o acoplamento dos meios empregados constituem o aspecto cognitivo" (ibid, p. 54). Nenhum dos dois aspectos se manifesta em estado puro. O dinamismo energético da teoria pulsional foi analisado especialmente por Freud nos sistemas e instâncias do aparelho psíquico e nas interações e progressiva diferenciação entre princípio de prazer - realidade; processos primários - secundários; Ego - Superego - Id. A dialética do desenvolvimento humano inclui a interação das pulsões sexuais e do Ego, que são diferentes ainda que indissociáveis: 
É precisamente a distinção entre Ego e sexualidade que nos possibilitou reconhecer com especial clareza que as pulsões do Ego passam por um importante processo de evolução, uma evolução que não é nem completamente independente da libido, nem desprovida de um efeito secundário sobre a mesma (Freud, 1916/1996, p. 354).

Para entender a construção das crenças infantis, pode ser útil assinalar uma correspondência entre as fases da evolução da onipotência das idéias assinalada por Freud (Totem e Tabu, 1913) e as fases do artificialismo elaboradas por Piaget. No caso da psicanálise, Freud propõe três grandes concepções humanas do mundo que correspondem a três fases do pensamento e são convergentes com os períodos do artificialismo propostos por Piaget. Em uma primeira fase, denominada animista, o homem se atribui a onipotência a si mesmo. Na religiosa, essa onipotência é transferida para os deuses, porém o homem não renuncia totalmente a ela porque ainda pode influir neles para favorecer seus desejos. Por último, na concepção científica do mundo, o homem reconhece sua pequenez, e se resigna e se submete às leis da natureza.

Como já foi mencionado, para Freud, o ser humano mostra dificuldades para renunciar a uma satisfação já desfrutada, portanto não se priva em termos absolutos da perfeição e completude narcísicas da infância. Que processo ao longo do desenvolvimento quebra esse estado de perfeição? São as admoestações próprias da educação e o despertar de sua capacidade interna de ajuizar. Por meio desses processos, o sujeito procurará recuperá-lo na nova forma de um ideal de Ego, que, como já foi mencionado, é também correlato à dissolução do complexo de Édipo. O ideal é o substituto do narcisismo perdido de sua infância, durante o qual ele mesmo era seu próprio ideal. Essa formação de ideal também pode ser pensada em relação à sublimação, entendida como um processo característico do período de latência que transforma a libido objetal e dirige à pulsão em direção a outra meta, situada em um ponto distante da satisfação sexual. A ênfase da transformação recai sobre o afastamento e desvio do que é sexual (Freud, 1914/2004, p. 112).

Assim, também na perspectiva piagetiana a socialização e as exigências do meio permitem a passagem do pensamento mágico ao lógico, constituindo assim um fator necessário, mas não suficiente. O primeiro período da construção do conhecimento sobre a origem das coisas consiste na crença em um artificialismo humano, no qual magia, animismo e artificialismo se confundem. O mundo é dirigido pelos homens, e toda ação é simultaneamente psíquica e física. Em um segundo momento o artificialismo pode ser transferido para o próprio Deus (quando a criança recebe uma educação religiosa), para logo passar a explicações de processos naturais e a um artificialismo cada vez mais imanente. 
Assim, a natureza se torna herdeira do homem e a partir dos 7/8 anos o egocentrismo diminui nitidamente em decorrência da socialização do pensamento. Dessa forma, para ambas as teorias, a evolução da referência em torno da qual o sujeito compreende o mundo poderia se sintetizar na série: Eu - Deus - Natureza.

Considerando a inteligência e a afetividade como dois aspectos indissociáveis da construção do conhecimento sobre a origem dos bebês, pode-se perguntar se a teoria da equilibração cognitiva poderia ampliar o estudo da teoria falocêntrica postulada por Freud. A teoria falocêntrica supõe a negação da falta do pênis nas meninas e a sua posterior compensação (todos têm pênis) que reintegra o equilíbrio perturbado. Porém, o que especialmente salienta essa teoria é a angústia e o conflito pulsional e psíquico que a diferença sexual e a origem dos bebês provocam nas crianças. A equilibração teorizada por Piaget supõe um jogo perturbação/regulação que não é de uma vez e para sempre. Assim, a teoria falocêntrica poderia ser pensada como um ciclo conflito/compensação, que se repete até que a observação do fato concreto das diferenças sexuais já não possa ser nem compensado nem negado (o qual não significa que o sujeito "resolva" as perturbações da sexualidade). Esse desenlace responde a aspectos cognitivos e afetivos. Por um lado, porque a estrutura cognitiva da criança atinge um nível qualitativo de inteligência que lhe impõe raciocinar em termos de necessidade e não de probabilidade (a diferença sexual é anatômica e não resulta contingente como a mudança de roupa). Por outro lado, porque a angústia e os conflitos procedentes do problema do nascimento e das diferenças sexuais podem ser abordados e elaborados a partir de níveis mais elevados de desenvolvimento psicossexual (como a sublimação e os processos secundários).

A contribuição de Kohlberg (1966) também permitiria estabelecer um paralelo entre o desenlace do Édipo e a consolidação da constância de gênero em relação ao fato reconhecido por Piaget de que o primeiro objeto dotado de permanência cognitiva é a pessoa do outro. Portanto, seria pertinente perguntar se a constância de gênero seria, em parte, uma consequiência da consolidação da identificação dos filhos com os pais do mesmo sexo e a instauração da sua própria identidade sexuada. Se durante o período sensório-motor o esquema de objeto permanente se afirma antes com os objetos-pessoas que com os objetoscoisas, poderia ser extrapolada esta seqüência à constância sexual. Assim, a consolidação da constância de gênero (aos 5/6 anos segundo Kohlberg) precederia a de quantidade de matéria nos objetos coisas (aos 7/8 anos). Ainda que diversas, essas apreciações não contradizem Freud, que embora nunca utilizasse o conceito de gênero, assegurou que a construção da identidade sexuada não é definida na anatomia, pois "todos os indivíduos humanos, à 
conseqüência de sua disposição bissexual, e da herança cruzada, reúnem em si caracteres masculinos e femininos, de modo que a masculinidade e feminilidade puras seguem sendo construções teóricas de conteúdo incerto" (Freud, 1925/1996, p. 286).

A construção das crenças sobre a origem dos bebês contempla aspectos cognitivos e afetivos a partir do duplo efeito de interesse e perplexidade que a sexualidade gera na criança. Os modos em que ela tenta resolver o problema foi explicado pela psicogênese piagetiana e pela psicanálise freudiana considerando alguns mecanismos psíquicos comuns. Para ambos os corpos teóricos, o problema constitui uma lacuna, um objeto de interesse e um obstáculo porque a criança não conta ainda com recursos cognitivos nem com a maturação psicossexual para abordá-lo. Porém, a criança não fica paralisada e consegue compensar essas dificuldades. Tanto a perplexidade como o interesse que gera a sexualidade são, ao mesmo tempo, cognitivos e afetivos. Ainda que existam essas perturbações, a criança consegue compensar o desequilíbrio com crenças cada vez mais complexas e elaboradas.

As relações entre afetividade e inteligência tem sido objeto de estudo em trabalhos contemporâneos. Na perspectiva de De Souza (2006), ainda que sejam apresentadas como mútuas e interdependentes, as pesquisas sobre inteligência e afetividade com frequiência recebem um tratamento dicotômico em relações de causa-efeito exclusivas: a racionalidade determinando o comportamento ou a afetividade como causa do desenvolvimento psicológico. Segundo a autora, a teoria piagetiana distingue as formas como estruturas que organizam a atividade do sujeito. Essas, por sua vez, são inferidas a partir dos conteúdos particulares aos quais se aplicam e que são a sua via de acesso.

$\mathrm{Na}$ linha do desenvolvimento moral, De La Taille (2002a), afirma que as dimensões intelectual (saber fazer) e afetiva (querer fazer) têm a mesma importância. Elas são analisadas separadamente "porque essa é a única maneira de torná-las inteligíveis. Mas o fato é que as duas dimensões interagem. Para se compreender tal interação, deve se evitar fazer um amálgama entre razão e sentimento" (ibid, p. 156).

Para Telles (1998), as vertentes afetiva e cognitiva do ser humano são simultâneas e indissolúveis, e não podem ser abordadas desconectadas uma da outra. A compreensão ou sentido dado a um estímulo carrega um afeto ou emoção e também a conseqüente ação do indivíduo. A afetividade remete a "que" e "como" um estímulo se significa. A autora coloca em questão a teoria do esquecimento freudiana, especialmente a amnésia infantil. Assinala que quando Freud aborda o esquecimento seletivo no período de latência, cabe lembrar que esse é justamente um momento fundamental, assinalado por Piaget, no desenvolvimento das estruturas cognitivas que modificam a noção de realidade para o sujeito. Contudo, há 
psicanalistas que aceitam outras respostas consistentes para entender o desenvolvimento do ser humano. Entre eles, é possível citar Décarie, o qual assinala que

A grande maioria dos psicanalistas está de acordo com Piaget em ver na evolução da afetividade uma reestruturação do universo, reestruturação que é efetivamente o produto de uma descentralização, onde processos perceptivos e intelectuais desempenham um papel considerável (Décarie, 1963 apud Telles, 1998).

No livro Piaget y el psicoanálisis, Delahanty e Perrés (1994) afirmam que a complementaridade entre as linhas de reflexão piagetiana e psicanalítica constitui uma tarefa ainda nova e que deverá ser desenvolvida pelos pesquisadores que, como eles, acreditam na importância das possíveis convergências entre ambas (ibid, p. 117).

Ainda que existam algumas controvérsias a respeito de um possível diálogo entre as clássicas concepções de sujeito piagetiana e freudiana (De Lajonquière, 1992; Kupfer, 2003; Jerusalinsky, 2010), se pode afirmar que enquanto para a psicanálise este é um sujeito do inconsciente ou do desejo, a psicogênese piagetiana se ocupa do sujeito epistêmico (sem por isso desestimar o papel do fator social e especialmente da afetividade). Diante do que foi exposto, é possível ressaltar que para Freud o inconsciente não determina a conduta humana em termos absolutos e que focalizar o estudo do "sujeito epistêmico" não significa que este se centre exclusivamente em atividades racionais ou que a afetividade esteja ausente na construção do conhecimento. Para os dois autores a inteligência e a afetividade não se apresentam em estado puro.

Piaget postula quatro fatores do desenvolvimento e o sujeito epistêmico emerge da convergência desses quatro fatores, necessários, mas não suficientes isoladamente: a maturação, a interação social, a experiência e o processo de equilibração que os integra (Piaget \& Inhelder, 1966/1972). Essa simultaneidade de fatores somada à dialética que estrutura a contínua interação do sujeito com o objeto-meio indica que o sujeito epistêmico resulta de uma complexidade de processos que supera amplamente a estruturação lógicomatemática.

De Souza (2006) observa que a teoria de Piaget se interessa pelas formas sendo que analisa as condições estruturais do desenvolvimento. Basicamente, procura explicar a gênese da construção de conhecimento no sujeito geral diferentemente da psicologia que enfoca um indivíduo particular. A respeito disso, em uma entrevista, o próprio Piaget explicou seu interesse específico pelo aspecto geral do desenvolvimento, diferentemente da psicanálise:

Meu problema está no conhecimento, eu não tenho razões para me ocupar de problemas afetivos, mas não é por discordar, é por distinção, diferenciação de interesses, não é meu domínio, e de uma maneira geral, eu tenho vergonha de dizer, eu me interesso pouco pelos 
indivíduos, pelo individual, eu me interesso pelo que é geral no desenvolvimento da inteligência e do conhecimento, enquanto que a psicanálise é, por essência, uma análise das situações individuais, dos problemas individuais. (Piaget apud Bringuier 1977/2004, pp.148-149).

Continuando com os autores contemporâneos que tentam superar a dicotomia afetividade-inteligência, vale mencionar a proposta da "psicanálise dos processos cognitivos" do psicanalista italiano Imbasciati (1998). Ele exprime idéias muito similares às piagetianas em relação à psicanálise. Nas palavras do autor, "o afeto é concebível como uma estrutura funcional, ativa ao modelar cada experiência, ao determinar como ela é vivenciada e o modo com que ela fica retida na memória" (ibid, p. 210-211, o negrito é nosso). Assim, a memória também é entendida como uma estrutura funcional ativa. Esses esquemas funcionais são adquiridos nas experiências precoces, ou seja, na vida psíquica primária. Por esse motivo cada indivíduo tem sua estrutura especifica afetiva adquirida de modo relacional. Atualmente, segundo o autor, nesse aprendizado precoce convergem estudos psicanalíticos, etológicos, psicossociais, antropológicos transculturais e cognitivistas, quando admitem a aquisição das estruturas afetivas em uma comunicação não-verbal do bebê com os adultos.

Para Imbasciati (1998), a distinção entre afeto e cognição só resulta meramente operativa em função do tipo de pesquisa conduzida. Essa distinção tende a ser anulada, especialmente quanto menor seja a idade do indivíduo a pesquisar. Ao longo da história, as diversas escolas psicológicas definiram os fenômenos afetivos de maneira diversa. A distinção entre sentimentos e emoções é a mais conhecida, mas também outros fenômenos foram diferenciados tais como "motivações, atitudes, preconceitos, expressividade, comunicação não verbal, sexualidade, todos mais ou menos dentro dessa área mais vasta chamada dos 'afetos"” (ibid, p.123). Conforme o autor, os processos afetivos sempre foram apresentados como mais obscuros e subtraídos à consciência do sujeito, por exemplo, com o termo "paixão", que indica um padecimento experimentado e obscuro à consciência.

As pesquisas atuais acerca da inteligência e afetividade convergem em indicar que em qualquer conduta humana, afeto e cognição são indissociáveis, assim como a sua forma e conteúdo. Nesta pesquisa, a forma de assimilar o problema de origem dos bebês é correlata às características das estruturas cognitivas e da organização psicossexual por meio das quais a criança assimila o real (objetos e fenômenos físicos e sociais). O conteúdo específico do nascimento, da fecundação e das diferenças sexuais foi abordado com maior ênfase pela psicanálise, a partir dos seus postulados sobre o desenvolvimento psicossexual da criança, especialmente da fase fálica e a dissolução do complexo de Édipo. Ainda que Piaget considerasse a importância da afetividade como motor e regulador energético, ele não chegou 
a se aprofundar no tema. Porém os textos em que levanta essa questão se apóiam especialmente na psicanálise. Nas suas palavras:

\begin{abstract}
não existe nenhuma conduta, por intelectual que seja, que não entranhe, como móveis, fatores afetivos; mas, reciprocamente, não poderia haver estados afetivos sem intervenção de percepções ou de compreensão que constituem a estrutura cognitiva. A conduta é, em conseqüência, uma, ainda quando as estruturas não expliquem a sua energética, e reciprocamente, esta não explique aquelas: os dois aspectos -afetivo e cognitivo- são, ao mesmo tempo, inseparáveis e irredutíveis (Piaget \& Inhelder, 1966/1972, p.156-157).
\end{abstract}

A psicanálise freudiana não ignorou as funções cognitivas (especialmente a atenção, memória e pensamento), mas focalizou os processos inconscientes sem aprofundar especificamente os problemas da construção do conhecimento e o desenvolvimento da inteligência. Entretanto, a partir do que foi exposto é possível dizer que ambos os autores integram a inteligência e a afetividade quando abordam o tema das crenças infantis a respeito da origem dos bebês. Freud não deixa de mencionar aspectos cognitivos nas teorias sexuais infantis, por exemplo, quando assinala a incapacidade da criança de diferenciar o orifício anal da vagina ou o desconhecimento do sêmen (1905/1996). Piaget também assinala aspectos mais especificamente afetivos, como os ciúmes pela chegada de um novo irmão e os sentimentos de deificação $^{12}$ que as crianças dirigem aos pais.

Tanto a psicogênese piagetiana como a psicanálise freudiana são teorias historicamente consagradas, cada uma na sua especificidade (desenvolvimento e clínica respectivamente). Dessa maneira, analisar os dados a partir do diálogo entre os autores permite considerar dialeticamente o problema da construção de um conhecimento particular (a origem dos bebês) a partir de algumas correspondências entre as ferramentas conceituais propostas por Piaget e Freud. Assim, o objeto de conhecimento (crenças sobre a origem dos bebês) implica ao mesmo tempo formas e conteúdos que mudam em relação às estruturas mentais e à afetividade do sujeito (crianças de 4 a 9 anos) que é ao mesmo tempo epistêmico e do inconsciente. Os resultados da pesquisa verificam as hipóteses estabelecidas no início, mostrando que a compreensão da construção infantil das "crenças sobre a origem dos bebês" se amplia e se aprofunda quando ambas são consideradas.

Neste trabalho, parte-se do problema do nascimento e da sexualidade entendido a partir de uma dupla demanda: do meio e do próprio corpo. A relação da criança com o saber sobre a origem e as diferenças sexuais se constrói a partir da dinâmica assimilação-acomodação e das distintas fases do desenvolvimento psicossexual. A progressão genética dessa dinâmica é originada num estado de indiferenciação caótica do "eu x não-eu”, até chegar a um estado de

\footnotetext{
${ }^{12}$ Sinônimo de endeusamento, divinização. Relativo a deidade: pessoa ou coisa que se admira e venera.
} 
diferenciação com coordenação correlata (Piaget, 1937/1975). A respeito da dinâmica assimilação-acomodação, Piaget explica que

a assimilação é conservadora e tende a submeter o meio à organização tal como ela é, ao
passo que a acomodação é uma fonte de mudanças e sujeita o organismo às sucessivas
imposições do meio. Mas se, no seu começo, essas duas funções são antagônicas, o papel
da vida mental, em geral, e da inteligência, em particular, é precisamente coordená-las entre
si (1937/1975, p. 328$)$.

Como já foi apresentado anteriormente, para Freud, o Ego se desenvolve progressiva e adaptativamente orientado pelo princípio de realidade a partir das camadas corticais do Id. Por essa razão, ainda que continuamente esteja em contato direto com o mundo externo, sempre levará a marca da sua origem. Para Freud o início de uma análise funciona como um método pelo qual se fortalece o Ego enfraquecido a partir da ampliação do autoconhecimento (1938/1974, p. 127). O lugar da “ação” para Freud também é muito importante quando atribui ao Ego a função de "elevar" os acontecimentos do Id a um nível dinâmico mais alto, transformando a energia livre em ligada. A respeito do Ego, Freud assinala que:

Sua função construtiva consiste em interpolar, entre a exigência feita por uma pulsão e a ação que a satisfaz, a atividade de pensamento que, após orientar-se no presente e avaliar as experiências anteriores, esforça-se mediante ações experimentais, por calcular as conseqüências do curso de ação proposto (Freud, 1938/1974, p. 144, o negrito é nosso).

Assim, a partir da perspectiva psicanalítica a instalação da consciência de culpa e a vergonha também podem ser entendidas nessa leitura do desenvolvimento. O Ego da criança ainda é débil e imaturo para dominar as excitações sexuais. Além disso, diante dos perigos do mundo externo, depende da proteção dos pais. Desta forma as crianças "pagam" esta segurança com o temor de perda de amor dos pais (ibid, p. 145). O conflito provém de que simultaneamente a esse temor, durante a fase fálica, a criança experimenta, por um lado, sentimentos ambivalentes em relação aos seus pais, e por outro, o mandato de interdição do onanismo. Em outras palavras, a criança vivencia sentimentos hostis pelo pai do mesmo sexo e deseja o do sexo contrário ao mesmo tempo em que experimenta a excitação do próprio corpo e o onanismo é rejeitado pelo contexto familiar e educacional.

Como complexificar a reflexão sobre essa situação a partir da psicogênese piagetiana? Poderia se considerar que a culpa se reforça nas crianças do período pré-operatório pela crença de que o adulto pode ter acesso a seus pensamentos. Esse fato é fundamental sendo que as crianças de 2 a 7 anos manifestam uma mistura de coação e subjetividade. Ao não dissociar totalmente seu Eu do mundo-ambiente, o pensamento pré-operatório assimila as fantasias às opiniões recebidas do exterior (Piaget, 1932/1994). Assim, o vínculo paterno filial projeta suas formas a outras situações sociais e naturais. 
O período da infância em dependência do adulto é assinalado por Piaget (1972b, p. 44) e por Freud como sendo muito prolongado em comparação com outras espécies animais. A noção de complexo de Édipo como matriz simbólica fundadora do desenvolvimento da criança resulta convergente com a afirmação piagetiana de que "durante o primeiro período do artificialismo espontâneo, a criança projeta em todas as coisas a situação que sente existir entre ela e seus pais" (Piaget, 1926/2005, p. 301). Em decorrência disso poderia se pensar que a angústia de castração, como angústia diante da falta, é compensada por um apego à crença. Portanto, existiria uma tendência à ausência de dúvidas ou questionamentos sistemáticos diante das experiências que a criança vivencia e tenta explicar. A angústia pela perda das "evidências primárias" desta etapa (cf. item 3.6) adiantaria a procura de verificação. O fenômeno é reforçado pelo medo da perda de amor dos pais (onipotentes e oniscientes) e acrescentado por sua vez pela ameaça da chegada de um irmão. Porém, é preciso lembrar que aqui se está fazendo referência à dúvida sistemática e à conseqüente procura de verificação própria do conhecimento científico, posto que afirmar a ausência absoluta de dúvidas aproximaria o desenvolvimento da criança a processos patológicos como os da psicose.

Como já foi assinalado, essa onipotência e onisciência que as crianças supõem nos pais devem cair e se desestabilizar em uma crise vital. Essa crise lhes permitirá abrir-se a novos objetos da cultura. Todavia, dependendo de cada criança, nem sempre essa crise se desenvolverá com a mesma intensidade, nível de qualidade nem na mesma época. Freud reconhece que a partir do complexo de Édipo vão se desenrolar processos emocionais muito intensos. Nas suas palavras: "Dessa época em diante, o indivíduo humano tem de se dedicar à grande tarefa de desvincular-se de seus pais e, enquanto essa tarefa não foi cumprida, ele não pode deixar de ser uma criança para se tornar membro da comunidade social" (Freud, 1916/1996, p. 340).

Ainda que a dissolução do complexo de Édipo seja uma tarefa proposta a todas as pessoas, para Freud raramente consegue ser enfrentada de maneira "ideal", ou seja, corretamente em termos psicológicos e sociais. Assim, o "infantil” da psicanálise é um termo que transcende a etapa cronológica de "ser criança". Essa singular noção do infantil constitui um ponto de diálogo interessante para entender a relevância das crenças sobre a origem dos bebês tanto na perspectiva piagetiana como freudiana. $\mathrm{O}$ conceito de egocentrismo contempla aspectos inconscientes e está intrinsecamente estruturado no vínculo da criança com seus pais e este vínculo vai ser um fator muito importante (ainda que não suficiente) para o futuro desenvolvimento autônomo da criança (autônomo em termos afetivos e intelectuais). $\mathrm{Na}$ 
perspectiva da psicogênese de Piaget, o "infantil" pode se estender até a idade adulta quando é entendido em termos de egocentrismo. Nas suas palavras:

O egocentrismo subsiste nos adultos em todas as circunstâncias em que eles são dominados por suas atitudes espontâneas, ingênuas e, por conseguinte infantis do pensamento (...) o egocentrismo infantil é um fato de conhecimento, um fenômeno epistêmico. É o conjunto das atitudes pré-criticas e, por conseguinte pré-objetivas, do conhecimento, da natureza ou de si mesmo. Não é um fenômeno de consciência (a consciência do egocentrismo destrói ou atenua o egocentrismo) nem um fenômeno de comportamento social (o comportamento manifesta indiretamente o egocentrismo, mas não o constitui), mas uma espécie de ilusão sistemática, inconsciente e de perspectiva. É egocêntrico sem saber (Piaget, 1923b/1999, p. $77-8)$.

As convergências acima apresentadas a partir do diálogo entre os corpos teóricos piagetiano e freudiano serão consideradas, a seguir, à luz dos dados coletados para uma abordagem mais integral da análise dos mecanismos psíquicos inerentes à construção das crenças sobre a origem dos bebês. 


\section{MÉTODO}

Considerando que o objeto de estudo desta pesquisa se refere aos processos psicológicos implicados na construção das crenças sobre a origem, a principal estratégia adotada foi buscar estudos que enfatizassem a análise do pensamento e a afetividade das crianças a partir da pergunta pela procedência dos bebês e das diferenças sexuais. Nesse sentido, as principais referências metodológicas foram: a tese de doutorado de Jagstaidt (1987), que realizou uma abordagem piagetiana e freudiana dos conhecimentos das crianças sobre a sexualidade; o trabalho de Kohlberg (1966) sobre a constância de gênero a partir da psicogênese piagetiana; e o trabalho de Juan Delval (2002) sobre o método clínico piagetiano no qual apresenta diferentes modelos de pesquisas, que utilizam procedimentos de campo muito similares aos deste trabalho.

De acordo com Delval (2002) para observar e estudar um fenômeno, deve-se partir de uma perspectiva teórica que oriente a pesquisa com categorias prévias. É preciso ter uma pergunta e o objetivo de buscar algo específico (porque um recorte prévio já foi feito), uma teoria que contextualiza o problema, e um método (coerente com a teoria) que se traduz em uma técnica e orienta no "como fazer". Um método poderia se definir como um caminho que se segue para chegar a uma determinada meta e se materializa em uma forma de obter dados para achar explicações gerais sobre uma parcela da realidade.

Esta pesquisa adota o "método clínico" criado por Piaget, o qual resulta coerente com a concepção de sujeito apresentada no segundo capítulo. Esta escolha se justifica não só porque permite entender com maior profundidade a sua teoria sobre o modo como as crianças explicam seus conhecimentos do mundo, mas ao mesmo tempo, guardando as devidas proporções, é o mais próximo ao método freudiano baseado na escuta dos seus pacientes.

\subsection{Participantes}

Para a coleta de dados, foram realizadas 80 entrevistas individuais semi-estruturadas com crianças de 4 a 9 anos, sendo 37 meninos e 43 meninas, organizadas em dois grandes grupos, segundo a faixa etária, sendo 40 crianças de 4 a 6 anos e 40, de 7 a 9 anos. 
Tabela 1. Distribuição das crianças, em freqüência absoluta e percentual, por idade

\begin{tabular}{cccc}
\hline Anos & Freqüência & Porcentagem & \\
4 & 14 & 17,5 & \\
5 & 10 & 12,5 & 40 \\
6 & 16 & 20,0 & \\
\hline 7 & 13 & 16,3 & 40 \\
8 & 21 & 26,3 & 80 \\
9 & 6 & 7,5 & \\
\hline Total & 80 & 100,0 & \\
\hline
\end{tabular}

Tabela 2. Distribuição das crianças, em freqüência absoluta e percentual, por sexo

\begin{tabular}{ccc}
\hline Sexo das crianças & Freqüência & Porcentagem \\
\hline Masculino & 37 & $46,3 \%$ \\
\hline Feminino & 43 & $53,8 \%$ \\
\hline Total & 80 & $100 \%$ \\
\hline
\end{tabular}

Tabela 3. Distribuição das crianças, em freqüência absoluta por sexo e idade em anos

\begin{tabular}{ccccc}
\hline \multirow{2}{*}{ Idades } & \multicolumn{3}{c}{ Sexo } & \\
\cline { 2 - 4 } anos & & masculino & feminino & Total \\
\cline { 2 - 4 } & 4 & 9 & 5 & 14 \\
\cline { 2 - 4 } & 5 & 4 & 6 & 10 \\
\cline { 2 - 4 } & 6 & 6 & 10 & 16 \\
\cline { 2 - 4 } & 7 & 8 & 5 & 13 \\
\cline { 2 - 4 } & 8 & 6 & 15 & 21 \\
\hline & 9 & 4 & 2 & 6 \\
\hline \multicolumn{2}{c}{ Total } & 37 & 43 & 80 \\
\hline
\end{tabular}

Tabela 4. Distribuição das crianças em freqüência absoluta por sexo por grupo etário

\begin{tabular}{|c|c|c|c|}
\hline \multirow{2}{*}{ Grupos etários } & \multicolumn{2}{|c|}{ Sexo } & \multirow[b]{2}{*}{ Total } \\
\hline & masculino & feminino & \\
\hline 4 a 6 & 19 & 21 & 40 \\
\hline 7 a 9 & 18 & 22 & 40 \\
\hline Total & 37 & 43 & 80 \\
\hline
\end{tabular}

\subsection{Procedimentos para a coleta de dados}

Os entrevistados pertenciam a instituições de ensino públicas e privadas de Barão Geraldo (Campinas-SP). Ainda que o foco da pesquisa não fosse o contexto, adotou-se esse procedimento para garantir certa diversidade de sujeitos. As entrevistas foram gravadas em áudio e realizadas nas dependências das instituições. Detectou-se que o melhor âmbito para realizá-las era a própria sala de aula da criança, porque ali se mostravam mais tranqüilas e 
familiarizadas com o ambiente. Porém, nem sempre foi possível utilizar este espaço nem evitar interferências de ruídos ou interrupções de outras crianças ou adultos. Ainda assim, essa situação não teve repercussões graves no andamento das entrevistas.

Previamente aos encontros com as crianças, foram realizadas entrevistas e reuniões com a Direção, a Coordenação da instituição e também com as professoras das turmas. Nesses encontros se informou acerca do Roteiro de Entrevista (Ver Anexo I) a realizar e foram apresentadas as pranchas com ilustrações utilizadas como recurso provocador (Ver Anexo II) ${ }^{13}$. Para realizar as entrevistas foi preciso enviar previamente um Termo de Consentimento aos pais das crianças (Ver Anexo III). As entrevistas só foram realizadas com as crianças com autorização dos pais ou responsáveis. Os termos informavam a aprovação da pesquisa pelo Comitê de Ética do Instituto de Psicologia da USP (Ver Anexo IV) e os detalhes acerca da pesquisa.

Como já foi mencionado anteriormente, escolher um método de pesquisa implica, primeiramente, a seleção de uma pergunta que oriente o trabalho, ou seja, um recorte específico da realidade como objeto de estudo. Para isso é preciso contar com uma teoria que permita aproximar do objeto com hipóteses que são corroboradas ou não a partir da aplicação do método. Para a construção dos procedimentos da coleta de dados, partiu-se da psicogênese piagetiana e da psicanálise freudiana com uma hipótese e, a seguir, foi realizada a coleta de dados seguindo o método clínico (com entrevistas verbais semi-dirigidas) elaborado por Piaget.

Escolher uma teoria implica também aderir a uma concepção de sujeito que dará forma aos procedimentos selecionados. Por sua vez, aplicar esses procedimentos metodológicos e estratégias de coleta de dados permite compreender melhor a teoria da qual se parte. No livro A representação do mundo na criança, Piaget (1926/2005, p. 11) fez uma escolha, que como toda escolha, implicou a perda de outras possibilidades. $\mathrm{O}$ autor renunciou à observação pura e à aplicação de testes como procedimentos de coleta de dados. Os testes não permitiam uma análise suficiente dos resultados por operarem sempre em condições idênticas com questionários fixos aos quais lhes falta um contexto mental. Porém, a maior falha que expõe Piaget com referência aos testes é que estes distorcem a orientação do espírito da criança por não permitirem variar as perguntas e fazer contra-sugestões.

Nesse sentido, o mestre de Genebra explica que "a arte do clínico consiste não em fazer responder, mas em levar a falar livremente e em descobrir tendências espontâneas em vez de

\footnotetext{
${ }^{13}$ A inclusão desse material será justificada no próximo item.
} 
canalizá-las e barrá-las" (Piaget, 1926/2005, p. 11). No caso da observação pura os obstáculos que se apresentam são: o egocentrismo intelectual da criança e a dificuldade de discernir o que é brincadeira ou fabulação do que é crença. Como já foi comentado, o egocentrismo intelectual resulta característico do pensamento da criança porque ela não procura e não consegue comunicar todo seu pensamento e cala suas explicações porque "lhe parecem ser as mais naturais e mesmo as únicas possíveis" (ibid, p. 13).

A escolha do método para a presente pesquisa se concentra nas entrevistas inspiradas no método clínico porque parte de uma concepção original de sujeito e se aproxima ao método psicanalítico por privilegiar a fala (ainda que com as crianças o dispositivo analítico focalize os desenhos e brincadeiras).

A respeito do método clínico, Delval (2002, p. 67) situa cinco etapas ao longo do percurso de pesquisas piagetianas. As suas diferenças dependem do tipo de problema que Piaget se propôs a investigar. A primeira etapa é nomeada de primeiros esboços (até 1926); a segunda de constituição do método, durante a qual prevaleceu o método verbal para estudar os conteúdos do pensamento (1926-1932); a terceira de método não verbal, aplicado aos bebês (1932-1940); uma quarta denominada manipulação e formalização com estratégias que priorizavam a resolução de tarefas (1940-1955) e uma quinta de desenvolvimentos posteriores com tentativas de voltar a usar dados estatísticos (a partir de 1955). As entrevistas realizadas foram inspiradas no método clínico da segunda etapa assinalada por Delval, ou seja, focalizando as entrevistas verbais e semi-estruturadas que foram realizadas utilizando pranchas ilustradas para iniciar cada bloco de perguntas. O procedimento escolhido responde às características assinaladas por Delval: “o entrevistador intervém sistematicamente e conduz suas perguntas de modo a tentar esclarecer o que a criança disse" (Delval, 2002, p. 69).

A presente pesquisa se enquadra nos trabalhos chamados estudos evolutivos, porque seu objetivo é observar e analisar como muda a crença sobre a origem dos bebês em crianças na faixa etária de 4 a 9 anos. O método escolhido é de tipo transversal porque estuda grupos de sujeitos segundo a idade permitindo verificar como mudam as representações ou condutas, recompondo o processo evolutivo por meio do estudo dos cortes correspondentes a cada idade (ibid, p. 47).

\subsection{Instrumentos}

Para operacionalizar a coleta de dados foram realizadas entrevistas semi-estruturadas constituídas por 17 perguntas básicas (cf. Anexo I) que fazem parte do roteiro geral; ademais, 
utilizou-se, como recurso provocador da fala, seis pranchas ilustradas com imagens de contos de fadas e personagens infantis (cf. Anexo II). As perguntas que surgiram durante as entrevistas foram de caráter complementar e orientadas pelas próprias respostas das crianças quando era necessário esclarecer o que elas disseram, conforme a indicação metodológica de Delval (2002, p.145).

Tomando como referência a pesquisa elaborada por Jagstaidt (1987), a entrevista foi organizada em blocos temáticos elaborados com base em uma adaptação e recorte das perguntas e das pranchas originais utilizadas pela autora na França e na Suíça. Esta pesquisadora realizou uma entrevista que consistiu em 57 questões na alternância de 16 pranchas de conteúdos específico e neutro, com base nos seguintes blocos temáticos: 1) Nascimento, fecundação e origem do bebê; 2) Vida intra-uterina e alimentação; 3 ) Diferença entre os sexos; 4) Nascimento e fecundação nos animais e 5) Representação do casamento. Ainda que a presente pesquisa tenha seguido este roteiro temático proposto por Jagstaidt, foram analisados apenas os três primeiros, por resultar mais específico para a análise das crenças sobre a origem dos bebês

Embora todas as questões da autora fossem interessantes, somente algumas foram selecionadas para esta pesquisa, e outras diferentes foram agregadas. O número de pranchas foi reduzido a um total de seis. Esta decisão se fundamentou, por um lado, no fato de que aplicar a técnica de Jagstaidt resultaria muito longo e cansativo para as crianças, especialmente para as menores. Por outro lado, o contexto escolar dificultaria a ausência dos alunos da sala de aula pelo período de uma hora. Ademais, os desenhos foram adaptados, porque a cultura visual das crianças brasileiras atuais difere da européia da década de 80 .

Para Delval (2002, p. 98), apresentar desenhos como ponto de partida constitui uma estratégia útil quando se entrevista crianças muito pequenas. Porém, os inconvenientes deste recurso foram experimentados no estudo piloto já que as crianças se centravam nos traços concretos do desenho e às vezes começavam a narrar um conto relacionado à imagem. $\mathrm{O}$ problema foi evitado apresentando a prancha unicamente no momento da primeira pergunta (“O que você está vendo?”) para logo após ser deixada de lado. Para começar as entrevistas foi perguntado às crianças se tinham algum irmão, bebês na sua família, etc. Ainda que os entrevistados fossem crianças pequenas, sempre se explicou previamente a entrevista e o objetivo da atividade: aprender como pensam as crianças da sua idade e averiguar o que eles sabem sobre o nascimento dos bebês. A apresentação da dinâmica foi a seguinte: "Eu vou te mostrar alguns desenhos e gostaria que você me respondesse algumas perguntas". O fechamento da entrevista com a realização de um desenho (livre) foi mantido por considerar 
que é preciso realizar um momento de criação autônoma e uma catarse psicomotora para relaxar, no caso de que alguma criança esteja cansada ou sensibilizada.

A partir do estudo piloto, importantes mudanças foram realizadas em relação ao instrumento de coleta. Tanto o roteiro da entrevista como as ilustrações foram aperfeiçoadas ao longo da realização do estudo piloto, a partir das apreciações das crianças sobre as mesmas. No transcorrer das entrevistas também ficou evidente a importância de explicar que não havia respostas "certas" ou "erradas" para evitar a tensão de uma situação avaliativa escolar do tipo exame, especialmente com as crianças mais velhas. Essa medida foi reforçada depois que a entrevistadora escutou uma criança de oito anos perguntar para outra (que tinha sido anteriormente entrevistada), se ela tinha respondido corretamente as perguntas ou tinha errado.

Em linhas gerais, após o estudo piloto chegou-se à conclusão de que as perguntas-base da entrevista deviam ser poucas e bem elaboradas; caso contrário, resultava cansativo e repetitivo para as crianças, especialmente para as mais novas. A experiência de realizar essas primeiras entrevistas foi fundamental, por um lado, para poder aperfeiçoar o roteiro e escolher as pranchas, e por outro, para que a pesquisadora começasse a aperfeiçoar a escuta característica do método clínico e melhorar as intervenções no momento de fazer perguntas suplementares ou contra-sugestões com o intuito de que a criança conseguisse explicar melhor as suas idéias.

\subsection{Procedimentos para a análise dos dados}

Para realizar a análise de dados foi considerada a proposta de Delval (2002, p. 170) de começar pela análise qualitativa, porque ao trabalhar com dados obtidos do método clínico, no início, tem-se diante de si uma enorme quantidade de material que parece desconexa e sem sentido. Primeiramente, é preciso descobrir as grandes tendências e os tipos de explicações gerais para depois, na análise quantitativa, ver as mudanças das concepções com mais detalhes, analisá-las e determinar se essas mudanças são significativas.

Portanto, no presente estudo, logo após ter realizado várias leituras das respostas coletadas se tentou definir as grandes tendências para elaborar níveis gerais de crenças. Só depois foi realizada uma análise quantitativa em tabelas de freqüência, calculando as porcentagens (o que resultou útil para determinar se existiam diferenças qualitativas significativas e consistentes nos grupos etários considerados). Os dados foram organizados em quadros divididos por faixa etária (para a análise quantitativa) e por categorias elaboradas 
a partir das tendências e elementos comuns que se evidenciaram na análise qualitativa dos relatos das crianças.

Em linhas gerais, a análise das formas e tendências das respostas foi baseada nas características das estruturas intelectuais próprias do pensamento pré-operatório, operatório concreto e da afetividade egocêntrica. Ao mesmo tempo, as formas e conteúdos foram interpretados à luz dos processos primários (condensação, deslocamento, negação, princípio da não contradição), das explicações freudianas para dar conta do conteúdo das teorias sexuais infantis e das características da fase fálica e do período de latência. Ao trabalhar com psicanálise é importante ser prudente para evitar "interpretações selvagens" fora do dispositivo do espaço de análise. Portanto, a abordagem do processo de construção das crenças a partir da coleta de dados focalizou mais as "formas" e mecanismos típicos que o conteúdo específico da fala singular das crianças. Fica a ressalva feita por Piaget de que é muito mais difícil de pesquisar a afetividade que os aspectos cognitivos (e, em parte, por essa razão ele não aprofundou seu estudo).

Em 1926, na introdução do livro A representação do mundo na criança Piaget estabelece cinco grandes categorias para os distintos tipos de respostas registradas nas crianças entrevistadas (só para esse livro foram entrevistadas mais de 600). São as crenças espontâneas, as desencadeadas, as sugeridas, a fabulação e o não-importismo. Piaget (1926/2005) designa o não-importismo como a atitude da criança que está entediada e que responde qualquer coisa. A fabulação é a resposta que a criança formula inventando uma história, mas sem acreditar nela. Se a criança busca agradar ao entrevistador que realizou uma pergunta sugestiva (as quais, segundo Piaget, são difíceis de evitar), surge a crença sugerida. Quando a criança nunca se deparou com a pergunta escutada e responde com reflexão própria há crença desencadeada (pela entrevista). Por último, as crenças espontâneas são aquelas que resultam prontas porque já foram formuladas pela criança anteriormente à entrevista.

A diferença entre as crenças é muito sutil e Delval (2002) adverte que nem sempre é fácil detectá-las. O grande problema com as crianças pequenas, segundo o autor, é que embora tenham algumas idéias sobre os fenômenos de seu entorno, elas não as expressam de maneira organizada ou sistemática porque não têm consciência dessa reflexão. Por isso, quando se pergunta à criança sobre algum assunto é difícil ter segurança do nível de espontaneidade da crença. Contudo, essas considerações evitam distorcer as respostas dos sujeitos tanto durante a entrevista como na sua análise.

Apesar das dificuldades para diferenciá-las, foi importante realizar essa triagem. Discernir o que provém da criança e o que foi inspirado pelo ambiente adulto é um problema 
bem complexo. O limite entre as crenças desencadeadas e as espontâneas é difícil de estabelecer, porém não resulta fundamental e as duas são de grande interesse porque nenhuma invenção vem do nada, mas supõe esquemas anteriores. Em resumo, dos diferentes tipos de resposta, Piaget assinala que as crenças espontâneas são as mais interessantes, porém as desencadeadas também nos orientam; a fabulação, se interpretada com cuidado, pode oferecer algumas indicações e por fim, as sugeridas e o não-importismo devem ser "severamente eliminados". Ou seja, no método clínico é preciso que a criança "autorize" ao entrevistador, portanto, não faz sentido nem resulta ético continuar com uma entrevista na qual a criança manifesta não ter interesse em responder ou se mostra desconfortável.

Durante a coleta de dados as atitudes de não-importismo foram poucas. As entrevistas foram sutilmente suspensas quando foi observado que alguma criança se mostrava incômoda, muito tímida ou desinteressada a partir de manifestações como: silêncio contínuo, começar a cantar depois de escutar a pergunta da entrevistadora ou reperguntar "quê?" sistematicamente, mas sem responder logo após escutar o esclarecimento oferecido. As respostas desencadeadas foram detectadas mais explicitamente nas crianças que já tinham recebido explicações dos pais (acerca da fecundação ou do nascimento da própria criança) ou tinham observado imagens de nascimentos na televisão ou em ultrassom.

Enfim, o vetor que orientou a interpretação das respostas foi a afirmação piagetiana de que "o princípio da interpretação das respostas desencadeadas, e até, em parte, das respostas espontâneas, consiste em considerá-las mais como sintomas do que como realidades" (Piaget, 1926/2005, p 27). Dessa forma, analisar essas crenças implica abordá-las como o produto de uma construção complexa, atravessada por diferentes processos e tendências. Portanto, é preciso ir além do seu conteúdo manifesto e literal e entendê-las como indícios de processos mentais e afetivos (como "a ponta do iceberg”). Na perspectiva psicanalítica, tal concepção remete, em parte, à noção de formação de compromisso entendida como a forma que adotam as produções do inconsciente para ser admitidas na consciência logo após ser deformadas para não ser reconhecidas. A noção de "formação do sintoma", por exemplo, designa o fato de ser o resultado da elaboração psíquica (Laplanche \& Pontalis, 2009). Como já foi assinalado (cf. item 3.2), essa elaboração contempla um aparelho psíquico com sistemas que respondem a legalidades específicas e que apresentam mecanismos típicos na gênese de suas formações. Conseqüentemente, tal como foi reafirmado por Freud com o conceito de realidade psíquica, elas nem sempre se correspondem com a realidade consensual. 


\section{RESULTADOS}

Os dados coletados neste estudo foram organizados em quatro eixos temáticos: 1) Fecundação; 2) Vida intra-uterina (alimentação do bebê); 3) Nascimento (saída da barriga) e 4) Diferença entre os sexos. Cada tema contempla sua análise qualitativa e quantitativa. Para a análise qualitativa, foram criados níveis das crenças a partir dos dados obtidos nas entrevistas e o diálogo teórico já desenvolvido nos capítulos anteriores. Esta parte analisa a qualidade dos dados a partir dos elementos teóricos piagetianos acerca da configuração intelectual e afetiva característica das faixas etárias estudadas e os construtos teóricos freudianos acerca do desenvolvimento psicossexual e dos aspectos psicodinâmicos do pensamento. Para a análise quantitativa, foram elaboradas tabelas de freqüência e porcentagens dos níveis de crenças, considerando os dois grupos de faixa etária das crianças. Para melhor visualização dos resultados, construímos tabelas e figuras, com o objetivo de analisar as tendências e regularidades. $\mathrm{Na}$ análise e discussão dos resultados foram também retomadas algumas características do percurso sócio-histórico da idéia cientifica de fecundação (preexistência, geração espontânea) e elementos da cultura sexual (vergonha, o tabu do sexo na escola, o sexismo, o fator social deformante e os suportes mediáticos), tal como expostas no primeiro capítulo.

A seguir os dados coletados serão apresentados de acordo com sua freqüência. Foram agrupados por eixo temático e por faixa etária e organizados em tabelas e figuras. As figuras foram construídas a partir de três recortes: i) comparação entre os grupos etários a partir do percentual de cada tipo de crença; ii) comparação global de cada grupo etário de acordo com cada tipo de crença; iii) análise do total das crenças de cada nível. Como já foi mencionado, os níveis das crenças foram construídos com base nos sucessivos períodos do artificialismo e animismo propostos por Piaget (1926/2005) nas suas pesquisas, considerando o nível de descentração das respostas (por oposição às mais egocêntricas). Vale assinalar que os eixos Vida intra-uterina e Diferença entre os sexos serão brevemente analisados a partir de uma tendência diferencial das crenças do último nível em relação ao sexo das crianças. A análise quantitativa dos eixos restantes relacionados com o sexo das crianças não mostrou diferenças que parecessem significativas (em termos de frequências relativas), portanto não serão incluídas no trabalho.

Por fim, serão apresentados exemplos das características gerais das formas de organização do pensamento e alguns traços da afetividade subjacente às respostas das 
crianças. As tendências do pensamento simbólico foram amplamente corroboradas nas entrevistas. A organização das respostas em correspondência a uma tendência por vez é uma forma de expor os dados para beneficio da análise. Contudo, em cada resposta podem ser verificadas várias tendências ao mesmo tempo. A análise simultânea das regularidades observadas a partir da coleta de dados é contemplada sob a forma de síntese no capítulo dedicado à discussão.

\subsection{Crenças sobre a fecundação: do pré-formismo à epigênese}

Os conceitos de pré-formismo e epigênese, escolhidos para analisar as crenças sobre fecundação fazem referencia às duas concepções teóricas que discutiram a fecundação até o século XIX (cf. item 1.4). Apesar da terminologia empregada, esta pesquisa se opõe à tese recapitulacionista. Piaget nunca defendeu o recapitulacionismo, ainda que nas explicações das crianças descobrisse certos traços análogos de antigas teorias científicas. A respeito disso, o autor afirma que a escolha do vocabulário para estabelecer níveis ou estágios de conhecimento "não foi nem para identificar a crença infantil individual com as crenças sociais primitivas, nem para opor à investigação sociológica uma psicologia social" (Piaget 1926/2005, p. 135). E agrega:

Desde que estabeleçamos nitidamente as diferenças entre o artificialismo infantil e o artificialismo grego, há vantagens no emprego da mesma palavra nos dois casos para designar a mesma tendência de confundir a causalidade material com a fabricação humana (ibid, p. 207).

De modo geral, os resultados a respeito dos conhecimentos sobre a fecundação variam entre idéias de preexistência do bebê na barriga, participação divina, alimentação excessiva como geradora de um bebê e a existência de uma semente de origem duvidosa, até idéias que mostram um início de epigênese ${ }^{14}$. As respostas coletadas acerca da fecundação foram organizadas em três níveis de crenças: mágicas, míticas e realistas.

Diante da quantidade e heterogeneidade nos conteúdos das respostas dadas pelas crianças, foi necessário analisar e inferir a forma de organizar seu raciocínio. Para obter uma idéia mais global acerca do nível de crença sobre fecundação em cada criança foi considerada

\footnotetext{
${ }^{14}$ Epigênese: 1. Processo de geração no qual o embrião é constituído por uma série de formações novas ou diferenciações sucessivas do ovo ou espermatozóide, nos quais não existem quaisquer esboços, mesmo rudimentares, da futura organização do indivíduo, resultante da união daqueles elementos. 2. Teoria da epigênese, também chamada teoria de pós-formação, formulada em 1759, em oposição à teoria da pré-formação e hoje universalmente aceita (Dicionário de português online: dicio.com.br/epigenese).
} 
a totalidade da entrevista. Para delimitar os critérios a partir dos quais optar por um ou outro nível, as respostas foram também avaliadas à luz das seguintes perguntas:

- Há indícios de pré-existência do bebê?
- Há participação sobrenatural?
- Há indícios de processos de fecundação ou gestação e matéria preexistente?
- Há participação dos pais? Ela é mágica ou realista?
- Há menção de indícios de relações sexuais?
- Se há matéria geradora do bebê, ela é interna aos pais ou externa a eles?
• O pai tem alguma função clara na fecundação?

Após várias leituras das entrevistas, considerando as perguntas acima citadas e os elementos teóricos anteriormente assinalados, foram construídos três níveis de crenças em relação à fecundação. Este eixo temático contempla as respostas às perguntas: "O que é preciso fazer para ter um bebê?" $\left(\mathrm{Q} 4^{15}\right)$; “Onde ele estava antes de estar na barriga da mamãe?” (Q11); “O que têm que fazer o casal se quer ter um bebê?” (Q13). O quadro a seguir apresenta as definições dos níveis das crenças com alguns exemplos.

\section{Quadro 1. Níveis das crenças em relação à fecundação}

\begin{tabular}{|l|l|}
\hline $\mathbf{N} 1$ & \begin{tabular}{l} 
MÁGICAS: Crenças pré-artificialistas com preexistência (pré- \\
formismo) e sem processos. Baseadas nas aparências ("deixar \\
crescer a barriga", "esperar"). O bebê já existe fora da barriga da \\
mãe ("desce do céu") ou sempre esteve dentro da barriga, já \\
formado. O verbo nascer na/da barriga significa "aparecer" e não \\
precisa explicitar o "como". O bebê não se forma, mas surge/brota \\
ao modo da geração espontânea. Pode haver participação \\
sobrenatural ("Deus, Jesus, anjinho"). Indícios de pré-causalidade \\
("os pais desejam"). \\
\hline MíTICAS: Crenças artificialistas de fecundação externa (sem \\
penetração). A matéria com que se faz o bebê pode ou não ser \\
procedente do corpo dos pais (ou apenas algum deles). O bebê não \\
se desloca nem aparece "do nada" e exige uma fabricação ou \\
processo. Admite crenças de fecundação oral (alimento
\end{tabular} \\
\hline
\end{tabular}

${ }^{15}$ As perguntas serão denominadas de questão $(\mathrm{Q})$, seguida do número $(1,2,3 \ldots)$ do Roteiro de Entrevista (cf. Anexo I). 


\begin{tabular}{|l|l|}
\hline N 3 & $\begin{array}{l}\text { fecundante ou semente que se engole) e/ou crenças com processos } \\
\text { (massinha ou semente da mãe ou do pai, que se coloca cortando a } \\
\text { barriga). Participação paterna duvidosa, ambígua ou inexistente. }\end{array}$ \\
\hline REALISTAS: Indícios de epigênese e artificialismo imanente. \\
$\begin{array}{l}\text { Participação dupla por "troca de matéria" ("um dá a semente para } \\
\text { o outro") ou por "troca sexual" (beijar ou "namorar"). Porém, a } \\
\text { função do pai ainda não é bem definida. Pode coexistir com traços } \\
\text { de crenças míticas. }\end{array}$ \\
\hline
\end{tabular}

Os níveis das crenças foram elaborados considerando os elementos comuns e mais recorrentes nas respostas. Em linhas gerais, as respostas classificadas nos níveis 1 e 2 apresentam duas noções recorrentes: 1) O bebê nasce "na barriga" (nascimento = fecundação) e; 2) a mulher é mais importante que o homem para ter um filho. O aparecimento deste tipo de argumento foi fundamental para estabelecer um critério que diferenciar os dois primeiros níveis do terceiro. Além de denominar o fenômeno da fecundação como "nascer na barriga", muitas crianças referem-se ao desenvolvimento fetal com a expressão "o bebê vai nascendo na barriga", utilizando assim o gerúndio do verbo "nascer" para exprimir a idéia de crescimento. Nas crianças mais velhas prevalecem os termos "desenvolver", "crescer" ou "formar". Vale ressaltar, por último, que os elementos comuns nas explicações aparecem de modo mais ou menos desenvolvidos nos conteúdos nas respostas singulares dos entrevistados. Entretanto, os níveis foram inferidos a partir da forma global da explicação da criança.

\section{N1 - Crenças mágicas sobre fecundação (nível 1)}

As crenças do nível 1 evidenciam relações estreitas com o estágio de "artificialismo difuso" proposto por Piaget, posto que a aparição do bebê tem caráter de preexistência. Conseqüentemente, não fazem menção a mecanismos de formação, apelando em suas explicações a Deus ou a um bebê preexistente (a pergunta pelo como se forma ainda não se coloca, mas a preocupação central é de onde vêm). A criança não demonstra estar interessada na formação do bebê. Um exemplo paradigmático é a afirmação recorrente "o bebê aparece na barriga da mamãe” sem ser acompanhada de mais explicações ou qualquer justificativa. De modo geral, há uma supressão do "como" e uma prevalência do "onde". Alguns exemplos de crenças mágicas correspondem às seguintes respostas: 
E25 (F 6) ${ }^{16}$ A pessoa fica querendo muito um bebê, então Jesus escuta a oração dele e traz um bebê para ele. Aí, vai no útero ${ }^{17}$ da pessoa e o bebê vai crescer mais. Você acredita nisso? (faz sim com a cabeça) ${ }^{18}$. Alguém falou para você? (faz não com a cabeça).

E15 (F 6,6) Se eles (o casal) querem ter um bebê então eles têm que... Precisava ir ao médico, depois de ir ao médico aí corta a barriga e sai o bebê que é a criação. Como chega o bebê na barriga? (pensa) como chega o bebê na barriga da mamãe?... Eu acho... Que é o papai do céu que põe ele lá dentro!

E1 (F 4,8) Para ter um bebê a gente precisa pedir para o papai do Céu (pensa) aí vai, vai, até que chega o bebê do céu. Aonde? Eu sei que ele vai na barriga só que para a mamãe tirar ele precisa.. Para ele nascer precisa ir num hospital.

E16 (F 5,1) (O casal) tem que fazer um bebê na barriga da mãe. Como? Abrem a barriga da mãe e depois colocam um bebê e depois tem que esquecer. Como eles colocam o bebê dentro da barriga? Cortam.

E4 (M 4,8) Onde estava o bebê antes de estar na barriga? No céu. A mãe pega o bebê. O papai do céu está no céu. Como ele desce? Faz uma mágica e aí o bebê nasce na barriga.

E30 (M 6,2) Quando a mãe merece um bebê, quando ela quer ter um bebê, aí ela trata bem o bebê, o filho dela que ela já teve, e Deus dá um outro bebê para ela. O pai tem que fazer algo? Não sei.

Pode-se observar que para E30, ter um bebê é a consequiência de um bom comportamento que é premiado por Deus. O fenômeno biológico da fecundação está regido por normas morais e heterônomas (prêmio-castigo), o que verifica a tendência à précausalidade (confusão entre a lei física e a lei moral). Outro aspecto a destacar é a presença de elementos religiosos nas crenças mágicas. Em relação à representação de Deus nas crianças, Piaget considera que ele é um termo genérico, como o sol ou a lua. Deus intervém nas respostas quando elas não encontram nada mais a propor, mas a criança entende que ele é um homem, um trabalhador ou um senhor como qualquer outro. A criança faz intervir Deus nas entrevistas como uma forma de fabulação (como se fosse Papai Noel ou uma fada) ou para atribuir a Deus uma atividade humana. Quando se insiste em demasia sobre as perfeições divinas a criança pode ver Deus como um rival de seus pais.

Piaget considera que a influência da educação religiosa pode alimentar um tipo de pensamento artificialista e mágico, o que foi verificado em algumas das entrevistas. $\mathrm{Na}$ perspectiva freudiana, a educação religiosa também pode gerar uma inibição do pensamento (cf. item 3.5). Portanto, tanto para Freud como para Piaget, dependendo do tipo de educação religiosa que a criança receba, ela poderia funcionar como um fator de inibição da autonomia intelectual. Nas respostas sobre fecundação, a figura de Deus aparece com um elemento

\footnotetext{
${ }^{16}$ Para todas as citações das entrevistas, os entrevistados serão identificados com a letra "E" seguida de um número, e entre parênteses, a letra $\mathrm{F}$ ou $\mathrm{M}$ (feminino ou masculino) e a idade (ano, meses). As frases em itálico correspondem às intervenções da entrevistadora e as reticências, às pausas da fala das crianças.

${ }^{17}$ Todos os erros gramaticais ou de expressão lingüística das crianças foram deixados para reproduzir suas falas do modo mais fiel possível.

${ }^{18}$ Os esclarecimentos da entrevistadora serão colocados entre parêntesis.
} 
controlador do fortuito e do acaso, sendo que certos fenômenos dependem da sua vontade. A menção a Deus apareceu em várias respostas das crianças e não só para explicar a fecundação. Pedir a Deus também pode ser uma estratégia útil para a escolha do sexo e a quantidade de bebês que se desejam:

E10 (F 5) Se a mãe quer um menino, ela pede para Deus, se a mãe quer uma menina ela pede para Deus, daí Deus dá menino ou menina. Se a mãe quer dois, Deus dá dois.

Em alguns casos notam-se certos indícios de dúvidas ou transição entre o discurso religioso da familia e uma tentativa de pesquisa autônoma:

E74 (M 7,3) Como chega o bebê dentro da barriga? Deus põe lá dentro. E a mulher que $f a z$ ? A mulher fala que ela quer ter um filho e se dá um filho para ela, ela abençoa Deus. Alguém falou isso para você? A minha avó. Você acredita nisso? Não. Em que você acredita? Que sai da barriga mesmo. Só nisso.

E15 (F 6,6) Alguém falou isso de Deus para você? (Logo depois de dizer que o bebê é colocado pelo pai do céu na barriga). Meu pai e minha mãe. Eles ficam falando tudo de Deus. É que foi o aniversário, na época é o aniversario de Deus, não é? (a entrevista foi feita em dezembro, próximo ao Natal). Então, eles falaram isso também.

E42 (M 9) Deus escolhe quem pode ter e quem não pode ter os filhos. Deus escolhe que família vai ganhar um bebê e qual que não vai ganhar. Você falaria isso para as crianças mais novas? Se eu pesquisasse e souber que era verdade eu falava. Mas você não sabe se é verdade? (faz que não com a cabeça).

Em algumas crenças mágicas foram manifestados elementos como "o espírito" e semelhanças com a idéia de reencarnação. Piaget (1926/2005, p. 291) reconhece que são freqüentes as crenças "de acordo com a qual os mortos voltam a ficar crianças pequenas e reaparecem na forma de bebês". Também Jung (1910) observou este elemento entre as inquietudes sexuais de sua filha Aninha (que surgiram com o nascimento do seu primeiro irmão). Esta supunha que a mãe ao ter o filho deve morrer para dar vida ao bebê. Como já foi mencionado, as crenças sobre a origem dos bebês estão relacionadas com a morte porque ambas seriam as duas faces da mesma moeda. As perguntas pelo início e pelo fim da vida são questões existenciais que se retroalimentam. Nas entrevistas ${ }^{19}$, as menções a esse respeito foram as seguintes:

E3 (M 4,8) Você sabe como nasceu seu irmão? (já tinha falado sobre o nascimento do irmão) Ele nasceu morrendo.

\footnotetext{
${ }^{19}$ Vale também ressaltar a crença manifestada em uma entrevista que não foi considerada nos resultados da pesquisa. A criança foi manifestando desconforto de falar sobre o tema, e, portanto a entrevista foi sutilmente suspensa. Contudo, o menino, de oito anos de idade, a partir da pergunta: "Como você explicaria a uma criança mais nova de onde vêm os bebês?" comentou: "Que alguém, depois que morre, sempre nasce de novo. No céu fica e escolhe. A mãe já começa a ficar grávida depois que nasce o bebê".
} 
E9 (F 5) Ele (o bebê) fica lá no céu e depois ele baixa na barriga da mamãe. Ele fica um pouquinho no céu e depois desce na barriga. E como é que ele entra na barriga? Eu acho que um espírito da mamãe que fica lá no céu, traz o bebê.

\section{N2 - Crenças míticas sobre fecundação (nível 2)}

Em relação às crenças denominadas míticas, resulta necessário explicar a escolha desse termo. Além de ser utilizado tanto na perspectiva piagetiana como na freudiana, há definições e características gerais da noção de mito que correspondem as já mencionadas acerca do tipo de pensamento pré-operatório. Chauí (2010) explica que um mito é uma narrativa sobre a origem de alguma coisa. Etimologicamente, vem do grego mythos e deriva de dois verbos: mytheyo (contar, narrar, falar alguma coisa para outros) e mytheo (conversar, contar, anunciar, nomear, designar). Em termos amplos, as crenças mágicas também compartilham traços da cosmogonia, entendida como a narrativa sobre o nascimento e a organização do mundo a partir de forças geradoras (pai e mãe) divinas ou por meio de alianças entre forças divinas e personalizadas. Nas explicações das crianças, podem ser observadas algumas alianças entre Deus ou Jesus que são invocados por meio da oração para cumprir os desejos dos pais.

Para os gregos "o mito é um discurso pronunciado ou proferido para ouvintes que recebem a narrativa como verdadeira porque confiam naquele que narra" (ibid, pp. 34-37). No caso das entrevistas, muitas das crianças mais novas também dão por óbvio que a sua fala é verdadeira. Sem a necessidade de convencer, suas respostas são verdadeiras pelo fato de que são elas mesmas que estão falando, e não precisam de nenhuma prova que verifique a verdade do que se afirma. Ainda que condensem diferentes informações em uma mesma frase, justapondo elementos, elas supõem que o interlocutor compreende o sentido das suas palavras sem necessidade de esclarecimentos.

Nos mitos, a autoridade e confiabilidade se situam na pessoa do narrador e não em provas objetivas. Chauí (2010) explica que essa autoridade vem de duas situações. Na primeira, a autoridade provém do fato de que o narrador testemunhou diretamente o que está narrando, o qual se comprova nas entrevistas quando a criança afirma que ela lembra quando estava na barriga e do momento em que saiu dela. Na segunda situação, a autoridade para afirmar suas explicações provém de haver recebido essa narrativa de alguém que testemunhou os acontecimentos narrados, o que se observa nas entrevistas quando as crianças explicam a origem dos bebês a partir de deformações das informações recebidas dos adultos, mas que acreditam estar reproduzindo de forma fiel.

Quando Piaget assinala que a dúvida ainda não é um problema para a criança, alude a um estatuto de crença na qual a palavra é da ordem do sagrado. Assim como o mito, ela é 
inquestionável porque não se importa com contradições, com o fabuloso e o incompreensível. Diferentemente, no pensamento operatório, as estruturas lógicas do pensamento dão recursos para novas coordenações e formas de equilíbrio, a partir da procura de coerência e não contradição.

As crenças míticas contemplam, entre outras explicações, a incorporação da semente pela boca, a formação do bebê em uma fábrica, a alimentação excessiva como causa da gravidez, a colocação da semente por um buraco na barriga da mãe. Vale acrescentar que nas crenças míticas o elemento da semente (muito utilizado nas explicações dos adultos) ganha relevância. Porém, esta idéia é assimilada pelas crianças a partir das características do pensamento pré-operatório e, portanto é deformada de acordo com as preferências e possibilidades de cada criança. Outro destaque merece a função paterna, que ainda se apresenta ambígua e contingente para a fecundação. Algumas das crenças míticas coletadas são as seguintes:

E7 (M 4,5) A minha mãe falou que o bebê nasce na barriga. Põe uma sementinha dentro da barriga e assim nasce o bebê. Ele põe uma semente dentro e depois nasce. Quem põe a semente? O meu pai. Como é essa semente? É um pauzinho de cada cor. Como se coloca a semente? Tem que cortar e depois costurar.

E13 (M 5,1) Põe a sementinha na boquinha.

E18 (M 6) Na verdade, acho que quando a mulher come muita coisa, a barriga fica engordando, quer dizer que o bebê estava nascendo.

Das respostas acima, observa-se que E18 manifesta a expressão "ir ou estar nascendo" para se referir ao processo de crescimento e desenvolvimento fetal. Utilizando a teoria da semente, E73 (M 7) (que já tinha recebido informação dos seus pais acerca da origem dos bebês) tenta dar conta do fenômeno da fecundação:

Primeiro eles (o casal) se casam, mesmo que eles não queiram, então nasce o neném. Só se casando? É. Daí por um tempinho nasce o bebê. Mas eles têm que fazer algo? Primeiro... Antes de o bebê nascer eles tem que fazer um curso, a mãe tem que fazer um curso de mãe e o pai tem que fazer um curso de pai. Para que é esse curso? Para eles conseguirem cuidar do neném... É por isso. E daí como aparece o bebêe? O bebê, na verdade, ele sai de uma semente, que sai do pai. Então o que acontece? Primeiro, a mamãe come a semente, a semente fica dentro da barriga e aí o neném vai nascendo, daí quando você aperta a barriga o bebê começa a se mexer, como eu.

E73 (M 7) mostra justaposição e contradição entre as informações recebidas e assimiladas a sua estrutura de pensamento. Quando já não consegue explicar a origem dessa semente isso gera um conflito que é compensado apelando a sua experiência pessoal e à explicação recebida da sua mãe, que foi o que ele conseguiu (e quis) assimilar (a idéia de 
nascer do desejo dos pais). Ao mesmo tempo, contradiz a crença anterior de uma semente ingerida pela mãe a partir da idéia de uma semente auto-produzida:

De onde vem essa semente? Na verdade, ela não vem de lugar nenhum. É a mãe que produz. E o pai faz algo? Faz eh... (pensa)... Dentro do pai produz uma semente, dentro da mãe produz uma semente, então, o que é que acontece?... Então, o que é que acontece? (pensa)... Quando, alguém começa a... Quando, alguém começa a namorar... (pausa) minha mãe me falou que eu nasci por causa do amor. Porque antes meu pai não se casou, nem minha mãe. Daí eles decidiram, daí minha mãe decidiu casar em outro momento, quando eu tivesse mais anos. E faz poucos dias que eles se casaram.

No discurso das crianças o problema da "teoria da semente" aparece com distorções e contradições por suas conotações botânicas. Além disso, a semente é uma matéria interna dos pais ou não provém deles? No geral é só a mãe que tem semente, mas essa idéia convive com outras crenças simultâneas. A semente contém o bebê ou vira bebê. Não há indícios da idéia de uma fusão de duas sementes (células) que formem um novo ser a partir da sua união como condição necessária.

Na perspectiva piagetiana acerca da distinção entre o possível e o necessário, pode se afirmar que, nas crenças míticas, a existência de duas sementes fusionadas ainda não atinge o grau de necessidade lógica para explicar a origem de um bebê. A teoria da semente surge, então, como um "possível" dentro de um contexto de crenças diversas. A criança seleciona e reconstrói a crença da semente segundo a sua conveniência, simultaneamente cognitiva e afetiva. Ela é, assim, assimilada a um quadro de crenças maior e significada de acordo com os interesses, valorações e estruturas mentais de cada criança. O elemento da semente para explicar a fecundação foi mencionado por E7 (M 4,5) ainda que de maneira sincrética e condensada com o fenômeno botânico:

Como será que os bebês chegam dentro da barriga? Tem que colocar sementes e eles nascem da semente, e aí, sabe o que acontece? Aí tem que tirar a casca. Onde se acham essas sementes? Tem que pegar das folhas. E o que se tem que fazer com as sementes? Você tem que jogar na água e depois coloca e pode colocar sementes e depois regar. E aí sai um bebê?? Não. Sai a planta, qualquer tipo de planta. Você coloca a semente na barriga e pronto, depois tira cortando. Como entra a semente na barriga? De qualquer jeito, tipo de pontinha. Tem que cortar a barriga com uma faquinha e aí coloca o negocinho dentro. Tem que pegar uma faquinha e furar. $A$ mãe ou o medico? É o meu pai, ele se chama João, ele furou, aí tem que colocar essa semente, duas, pra o bebê nascer. Porque a semente, o bebê nasce na semente porque... Aí ele poder nascer, sabe aonde? Lá na barriga, aí você corta a barriga. Como é que você sabe isso da semente? A semente vem da folha, eu aprendi. 
Para responder às questões sobre fecundação, E18 (M 6) apela à explicação da alimentação fecundante, tanto nos humanos como nos cachorros. A quantidade de comida que se ingere faz depender também o sexo do bebê e permite uma participação mágica do pai:

$\mathrm{Na}$ verdade, acho que quando a mulher come muita coisa, a barriga fica engordando, quer dizer que o bebê vai ficando... quer dizer.... que o bebê estava nascendo ( $\mathrm{Q} 4)$. Acho que quando ele (o cachorro) come muito, o bebê vai nascendo igual do jeito da mãe (dos humanos). Então quer dizer que o filhote vai nascer. (Q 5)

Não. Porque o homem ele não é a mulher então... Os homens... Eles comem muito, muito e isso não ajuda para o bebê nascer... Então é isso, só a mulher pode ter bebês (Q14b).

Praticamente, quando a mãe come muito, muito, muito, quer dizer que vai nascer um menino. Quando a mãe come muito, muito quer dizer que vai nascer uma menina (Q15).

E19 (M 6,3) e E69 (M 7,2) também explicam a fecundação justapondo a alimentação como parte do processo:

E19 (M 6,3) Quando você está comendo muito, aí começa a sentir uma dor, quando está um pouco doendo aí sai. Vai para o médico e faz uma injeção.

E69 (M 7,2) A mulher tem que casar ou namorar para o bebê nascer. Tem que esperar bastantes dias comendo muito, a barriga dela vai ficar grávida e aí vai ter o bebê. Ela fica grávida por comer comida? É. E o homem que faz? Homem não pode ter bebês, porque só mulher tem bebê.

A teoria da comida fecundante é assinalada por Freud (1910) em intrínseca relação com a teoria cloacal e a função "obscura" do pai. Isto implica entender a fecundação a partir dos próprios esquemas de ação e do próprio corpo da criança a partir dos quais ela sabe que o pênis e a vagina são órgãos estritamente úteis para "fazer xixi" e que o que entra na barriga sai pelo ânus. Portanto, para Freud as explicações das crianças excedem as possíveis informações recebidas dos adultos, e tal como para Piaget, elas são construídas a partir das possibilidades correspondentes a seu nível de desenvolvimento psicossexual.

Para E11 (F 5,1) a fecundação combina uma fábrica de bebês e a utilização de massinha. Esta crença artificialista entende a formação do bebê como se fosse a construção de um objeto:

O que eles (o casal) têm que fazer se querem ter um filho? Têm que fazer um bebê. Como? Tem que pegar massinha. Como? Fazendo um bebê. Na fábrica de fazer bebês. E como é? Eu não sei como é. E quando sai da fábrica para onde o levam? Para a barriga da mãe. E como entra? Cortam a barriga.

Segundo Piaget (1926/2005) é freqüente que as crianças se perguntem pela formação de cada órgão, "como se cada um tivesse sido fabricado à parte'. O autor retoma várias 
perguntas que apelam a esta idéia, que foram publicadas por Melanie Klein e outros autores. A respeito disso, uma professora de educação infantil narrou uma situação vivenciada em uma sala de crianças de 4 anos e que ilustra esta crença da fabricação do bebê "por partes":

Durante o mês de maio, no trabalho sobre o dia das mães e sobre o dia do trabalho, nós tínhamos uma mãe que estava grávida e uma mãe obstetra. Então as duas foram convidadas para a gente poder assim deixar a situação do nascimento bem clara para as crianças. A mãe levou o soar, as crianças ouviram o som do coração do neném, e é claro que a gente já sabia que alguém ia perguntar como é que a criança sai daí. E um menino perguntou, como é que o bebê nasce? Aí a obstetra falou: - Bom, primeiro sai a cabecinha, depois o corpinho e por último o pezinho. E o menino falou: - E depois monta, não é?

A citação acima mencionada verifica "o fato de a criança conceber como complementares e não contraditórios o animismo e o artificialismo. Não há nenhuma dificuldade na idéia de que se fabricam seres vivos, dado que os próprios bebês são fabricados" (Piaget, 1926/2005, p. 294). Acrescenta-se a isso que a intenção adulta de ensinar sempre resulta em um processo relativo ao modo em que cada criança assimilará essa informação de acordo com seus esquemas mentais.

\section{A função paterna}

Em decorrência das dificuldades de entender a fecundação, a função do pai também resulta confusa e quase não é mencionada pelas crianças novas de maneira espontânea. Vale lembrar que há uma convergência entre Piaget e Freud a respeito da construção das crenças sobre a função dos pais na fecundação, porque elas passam da causalidade espacial por sentimentos de participação (o bebê aparece na barriga e os pais têm algo a ver com isso) a se perguntar acerca do papel concreto dos pais (como chega dentro). Como já foi mencionado (cf, item 3.5), o pênis é a chave do mistério para o papel do pai na fecundação, e será alvo de pesquisas infantis quando o mero fato de que o bebê se localiza no corpo da mãe já não resulte suficiente. No texto Totem e tabu, Freud menciona a teoria dos Arunta que suprime o nexo entre a fecundação e o ato sexual. Assim, o papel do homem fica duvidoso pelo prolongado intervalo entre a fecundação e o nascimento. O mito narra que:

Quando uma mulher se sente mãe é porque nesse instante penetrou em seu ventre um dos espíritos em busca de renascimento desde a sede de espíritos mais próxima, e ela o parirá como filho. Esse filho terá o mesmo totem que todos os espíritos do lugar assinalado (Freud, 1913/1989, p. 120). 
Ao obstáculo cognitivo de entender o papel do sêmen e dos espermatozóides se soma, na perspectiva freudiana, a dificuldade de compreender a existência e função da vagina. Em decorrência disso, nas crenças sobre fecundação das crianças mais novas a função paterna é vaga ou inexistente:

E10 (F 5) O pai faz algo para ter o filho? Homem não tem filho. Mas você tem pai? Eu tenho pai. Você é filha de seu pai? Sim, só que eu nasci da barriga da minha mãe. $O$ que ele fez para você nascer? Ele ficou com a minha mãe, ele tinha se casado com minha mãe, eles se casaram, aí meu pai ficou fora e quando ele foi entrar eu já tinha saído da barriga da minha mãe que meu pai queria ver sair!

E12 (F 5) Bebê é uma coisa de mulher, não é coisa de homem.

E27 (F 6,6) Você falou que a mãe tem uma semente, e o pai que faz? Ele espera, fica bebendo água até a noite, e fica comendo a comida.

E69 (M 7,2) Os homens às vezes são pais; porque eles são pais dos bebês? Porque se eles têm mãe, tem que ter alguém para ser pai dele, que são os homens. Só pode ser pai quem tem filho. Então o que faz o homem para ter filhos? Não sei. Eu sei como que a mulher faz para ter filhos, mas o homem não tem filhos.

A resposta de E69 acima citada mostra indícios de pré-causalidade, sendo que os homens são pais pelo fato de que se um bebê tem mãe, tem que ter alguém para ser pai, como se fosse uma espécie de lei moral. Ele ainda não consegue explicar a participação paterna em termos biológicos. A seguinte resposta de E35 (F 5,2) lembra a concepção da virgem Maria pelo espírito santo (ou seja, sem contato carnal com um homem), em uma situação contraditória em que Deus e o marido da mulher são pais do bebê. Na figura paterna se condensam Deus e o homem, que é pai do bebê pelo fato de trabalhar:

Ela (a mulher) espera um monte de minutos para ter um bebê dentro da barriga. Tem que esperar, o Deus tem que pegar um bebê e por dentro da barriga. De onde pega Deus o bebê? Ele espera e quando Deus quer ter um bebê numa mulher aí ele põe o bebê, fica lá na barriga. Então Deus é o pai do filho? O marido. E o marido que faz para ser o pai do filho? Ele trabalha. Como faz Deus para colocar o bebê na barriga? Ele fica lá no céu, e depois ele nasce dentro da barriga da mulher. E se a mulher não quer ter filhos Deus coloca do mesmo jeito? Coloca do mesmo jeito. Então a mulher não decide? Sim, e o marido também decide.

Algumas respostas às perguntas Q14 ( a."Você acha que uma mulher poder ter um bebê, sozinha sem um homem?" b. "E um homem sozinho, sem uma mulher?”) reafirmam essa idéia ambígua acerca da função do homem na procriação:

E5 (F 4,8) a. Pode, ela é mulher! O que tem que fazer? Eu não sei que tem fazer para ter um bebê. b. Não porque ele é homem, só a mulher tem.

E10 (F, 5) a. Pode. Pedindo para Deus. b. Não pode. Porque o homem não é mulher.

E25 (F 6) a. Pode. É como eu te falei. Ela quer engravidar e aí ela vai lá no médico para ver se ela engravidou. 
E30 (M 6,2) a. Não, porque aí não ia ter pai! b. Não. Porque mulher tem peito e homem não tem.

Em relação à pergunta Q14, um entrevistado afirma que o homem sozinho pode ter um bebê, em uma situação que lembra o complexo de Édipo. Posteriormente, em uma mesma resposta menciona a seqüência "bebê na barriga - pai - terror":

E13 (M 5,1) O homem sozinho pode ter um bebê sem uma mulher? Pode... Pode com a mamãe dele. E se ele ficar junto com a mamãe ele fica com um bebê da mamãe dele. Ele (o bebê) está na barriga ainda, ele ainda fica. Quando ele fica na barriga ele fica aí, dentro da barriga (pausa)... Meu pai, ele fica assistindo filmes de terror que eu nem quero olhar.

Algumas explicações das crianças do grupo etário de 7 a 9 anos acerca da função paterna resultam mais refinadas e realistas (incluem adoção, anticoncepcionais, etc.), porém a função do pai continua sendo "obscura" ou confusa. Vejamos alguns exemplos:

E42 (M 9) Q14a: Não sei. Eu acho que não. Só se ela adota um bebê. b: Não, só se ele também adotar.

E47 (F 8,6) Q14: Se ela não tomar os remédios pode. Para que servem os remédios? Tem os remédios certos para não engravidar a mulher. E o pai tem que fazer algo para ter um bebê?? Não. Acho que não.

E48 (F 8,9) Q14a: Não. b: Não. Que tem que fazer um rapaz se quer ter um filho? Namorar com uma mulher.

E49 (F 8,7) Q14a: Não. Porque tem que ter casado para ter filhos. Porque sem pai não dá para ter filho. $O$ que é que o pai faz para ter filho? Pai não tem filho, é a mãe que tem. Aí ela arruma namorado e arruma um filho. E porque sozinha não pode ter? Porque tem que fazer um monte de coisas. b: Não. Porque a mulher, ela tem uma coisa, ela é mulher e ele é homem, e ele não pode ter filho sem mulher.

E76 (F 8,6) Por que um pai é o pai? Porque a moça está casada com esse rapaz. Aí o filho chama de pai. Se chamar de outra coisa ou pelo nome, o pai vai ficar bravo, porque tem que chamar pai, não pelo nome.

E55 (M 9) Quem é mais importante para ter um filho, o homem ou a mulher? A mulher, porque ela que pode fazer ter um filho.

E56 (F 9) Porque um pai é pai do bebê? Porque ele se casa com a mulher.

E59 (F 8,7) Um rapaz sozinho pode ter um bebê? Acho que não, mais ou menos sim, mas não. Por que um rapaz é pai, o que ele faz para ter o bebê? Apóia a mulher dele e ajuda ela a se controlar às vezes. Às vezes tem bebês que a mulher não pode ficar muito irritada, não pode ficar muito agitada, aí ele ajuda a se controlar.

A resposta de E76 mostra indícios de pré-causalidade e realismo nominal, já que o pai de uma criança é pai pelo fato de estar casado com a mãe do bebê (ou seja, é uma conseqüência mais do vínculo afetivo do que biológico) e porque ele é chamado de "pai" pelo filho. Em relação à função paterna, as diferenças entre os dois grupos etários estão focadas nos modos de fundamentar as respostas. Enquanto as crianças mais novas justificavam a 
função paterna com respostas do tipo "bebê é coisa de mulher", as mais velhas conseguem estabelecer outras relações para argumentar a importância do pai na fecundação. Ainda que na maioria das respostas o pai seja considerado um agente ativo da fecundação, a partir da pergunta Q14 pode se perceber algumas características ambíguas acerca do papel do parceiro masculino: a paternidade se consuma no fato de ser o marido da mãe do bebê e um sustento psicológico e material da mãe (ele a apóia, ele trabalha, portanto a mãe precisa do homem para dar conta da maternidade). Ainda restam idéias de uma mulher auto-suficiente para ter um bebê, e, portanto, em muitos casos, a figura paterna não tem caráter de necessidade lógica para fecundar.

\section{N 3 - Crenças realistas sobre fecundação (nível 3)}

As crenças realistas prevalecem nas crianças do grupo etário de 7 a 9 anos. Elas contemplam indícios de relação sexual e de epigênese, ainda que poucas crianças manifestem entender o processo de penetração para fecundar o bebê. Alguns exemplos são:

E42 (M 9) Tem que dormir na cama juntos, aí depois eles, querem ter um filho né? Aí depois nasce, e depois a mulher vai lá no hospital e nasce um filho, se ele é homem. E se eles não querem ter um filho? Eles não fazem isso lá na cama. Eles dormem separados? Eles dormem na mesma cama, mas não fazem isso. Ou eles dormem em cama separada.

E66 $(F, 8,4)$ Geralmente quem quer ter um bebê tem que casar, porque senão não dá. Aí eles casam, e se a mulher quer ter um bebê ela tem, e se não quiser ela não tem o bebê. $O$ homem não faz nada? Acho que ele faz, acho que ele passa a semente para a mulher. Dá a semente na barriga da mulher, e daí o bebê vai crescendo.

E44 (F 8,9) O que faz o pai para ter um bebêe? Não sei (pensa). Ele namora a mãe, depois a mulher fica com vontade de comer alguma coisa, daí o moço vai e compra. Daí o bebê começa a se formar.

E 67 (M 8,11) Explicaria que o homem tem uma semente que passa para a mulher, e que a mulher tem uma coisa para nascer que o homem não tem.

E65 (F 7,6) Tem que colocar o espermatozóide dentro da mulher e aí o espermatozóide vai tem que passar por várias aventuras dentro da mãe $(. . .)^{20}$ como chega o filhote do cachorro dentro da barriga? Primeiro o homem, ele bota o espermatozóide. Aí o espermatozoide tem que ir até o óvulo para encontrar e fazer um neném dentro da barriga. Isso passa com os cachorros? Acontece com todos os mamíferos.

E69 (M 7,2) Onde estava o bebê antes de nascer? Ele ainda não estava em nenhum lugar. Aí quando ele começa... a primeira vez que ele começa a crescer ele começa numa sementinha. Aí depois ele vai como um grão de arroz, depois tem o tamanho de um feijão, depois de um melão, aí depois ele nasce.

\footnotetext{
${ }^{20}$ Os três pontos entre parêntesis (...) indicam que o que segue foi afirmado em um momento posterior da entrevista, mas segue a linha argumentativa sobre o mesmo tema.
} 
E68 (F 7,6) Uma mulher sozinha pode ter um bebê? Não. Pode até se casar e depois não querer mais. Mas sem marido não tem filho, porque precisa da semente do marido para ter filho. Como se juntam as sementes? Junta o pipi com a perereca.

Na resposta de E65 acima citada, observa-se um indicador operatório de classificação. Os seres humanos se reproduzem a partir de princípios que são compartilhados com outras espécies porque pertencem a um grupo mais amplo (inclusão de classes) dentro de uma hierarquia de agrupamentos (seres humanos < mamíferos < animais). A resposta de E69 evidencia a negação da preexistência e indícios de seriação, entendidos nos processos de transformação a partir de mudanças de tamanho. A seriação que exprime E69 implicaria as noções de "menor que" e "maior que" em contraposição ao pensamento pré-operatório que só procede por pares que não são coordenados em uma série única. No caso de E68, ele enfatiza a função paterna em termos de necessidade lógica: a semente do marido é necessária para ter um bebê, e, por conseguinte não pode ser fecundado na mulher sem participação masculina.

Esse caráter de "necessidade" está em relação com o que Piaget (1964/1975) chama de “equilibração progressiva" e que conduz a uma estrutura lógica ou "necessária”. Ademais, em relação aos possíveis indícios de classificação e seriação de E65 e E69, o seguinte esclarecimento de Piaget resulta útil:

as primeiras estruturas concretas descansam todas em operações de classes e de relações (mas sem esgotar a lógica de classes nem a de relações) (...) sua função essencial consiste em organizar os diversos campos da experiência, mas sem que haja ainda diferenciação completa entre o conteúdo e a forma (ibid, p. 178).

\section{Análise quantitativa das crenças sobre fecundação}

A partir dos dados coletados, foram realizadas tabelas e figuras para organizar a freqüência dos níveis de crenças sobre fecundação, de acordo com a faixa etária dos entrevistados.

Tabela 5. Distribuição de frequiência absoluta e percentual das crenças sobre fecundação por grupo etário

\begin{tabular}{cccccc}
\hline Grenças & não sei & mágicas & míticas & realistas & Total \\
\hline 4 a 6 & $2(5 \%)$ & $22(55 \%)$ & $16(40 \%)$ & $0 \%$ & $40(100 \%)$ \\
\hline To 9 & $3(7,5 \%)$ & $6(15 \%)$ & $9(22,5 \%)$ & $22(55 \%)$ & $40(100 \%)$ \\
\hline Total & $5(6,3 \%)$ & $28(35 \%)$ & $25(31,3 \%)$ & $22(27,5 \%)$ & $80(100 \%)$ \\
\hline
\end{tabular}


Figura 1. Distribuição comparativa das freqüências de crenças sobre fecundação de cada nível por grupo etário

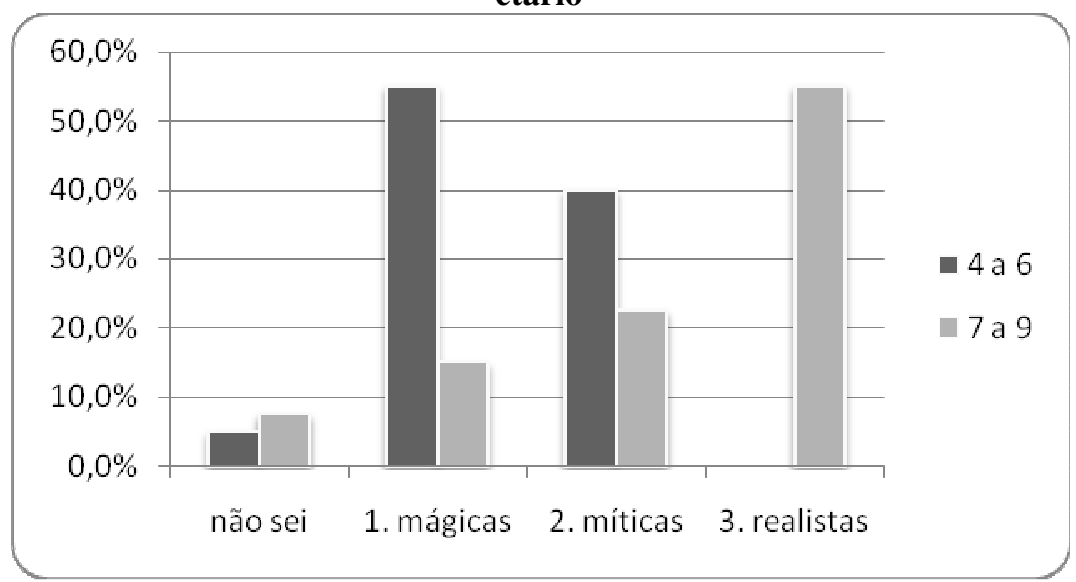

Os dados evidenciam que enquanto mais da metade das crianças mais novas $(55 \%)$ manifestam crenças mágicas, só $6(15 \%)$ crianças de 7 a 9 anos apelam a elementos mágicos (por indícios de educação religiosa). As respostas míticas também têm prevalência no grupo de 4 a 6 anos. Chama a atenção que enquanto há ausência de crenças realistas nas crianças novas, elas são referidas pela maioria das crianças mais velhas (55\%). Esses dados confirmam a hipótese de uma progressão do pensamento que vai da prevalência da contradição e os processos primários, a um pensamento mais lógico e descentrado. Essa progressão qualitativa dos níveis das crenças e a concentração majoritária nas crenças realistas sobre fecundação no segundo grupo etário, pode ser melhor observado na figura abaixo:

Figura 2. Distribuição percentual das crenças sobre fecundação em cada grupo etário

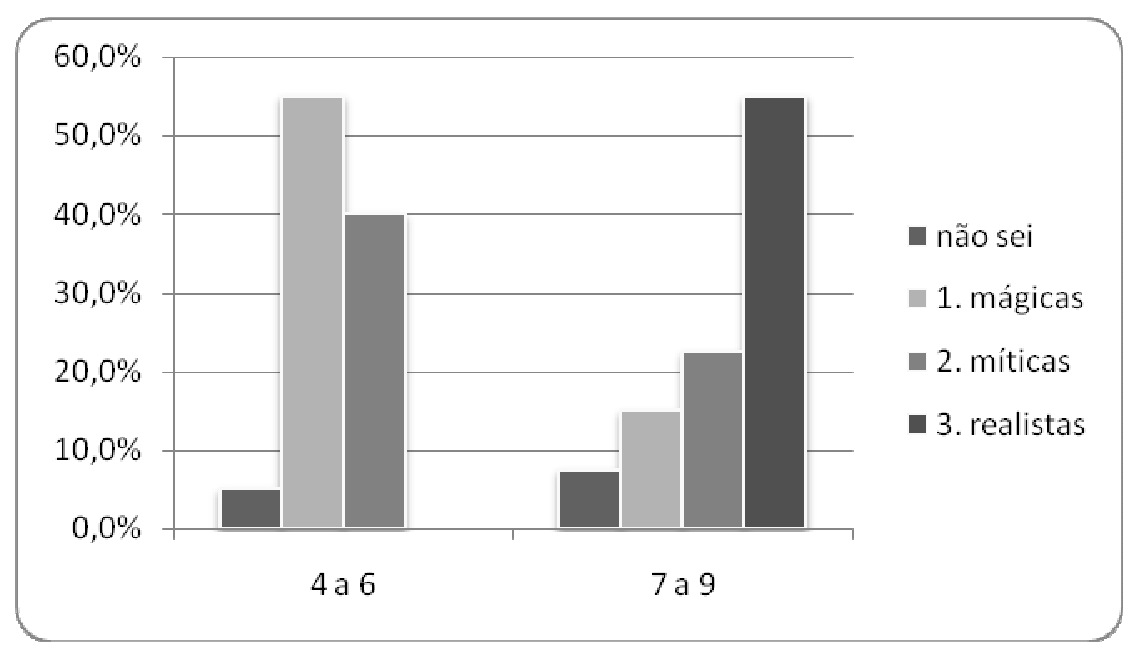

Com relação ao grupo das crianças mais novas, observa-se uma maior prevalência de crenças mágicas (55\%) que somadas às míticas atingem um 95\% para o total de crenças desse grupo. Verifica-se também que a maioria das crianças de 7 a 9 anos (55\%) manifestam 
crenças de nível 3 (realistas), sendo relativamente baixas as porcentagens de crenças mágicas e míticas, que somam $37,5 \%$ do total das respostas. Vejamos, a seguir, como se distribui a frequiência no interior de cada crença, segundo os grupos etários:

Tabela 6. Distribuição percentual das crenças sobre fecundação em cada nível.

\begin{tabular}{cccc}
\hline Grupo etário & $\mathbf{4}$ a $\mathbf{7}$ & $\mathbf{7}$ a $\mathbf{9}$ & Total \\
\hline não sei & & & \\
\hline mágicas & $40 \%$ & $60 \%$ & $100 \%$ \\
\hline míticas & $\mathbf{7 9 \%}$ & $21 \%$ & $100 \%$ \\
\hline realistas & $64 \%$ & $36 \%$ & $100 \%$ \\
\hline
\end{tabular}

Figura 3. Distribuição percentual das crenças sobre fecundação em cada nível.

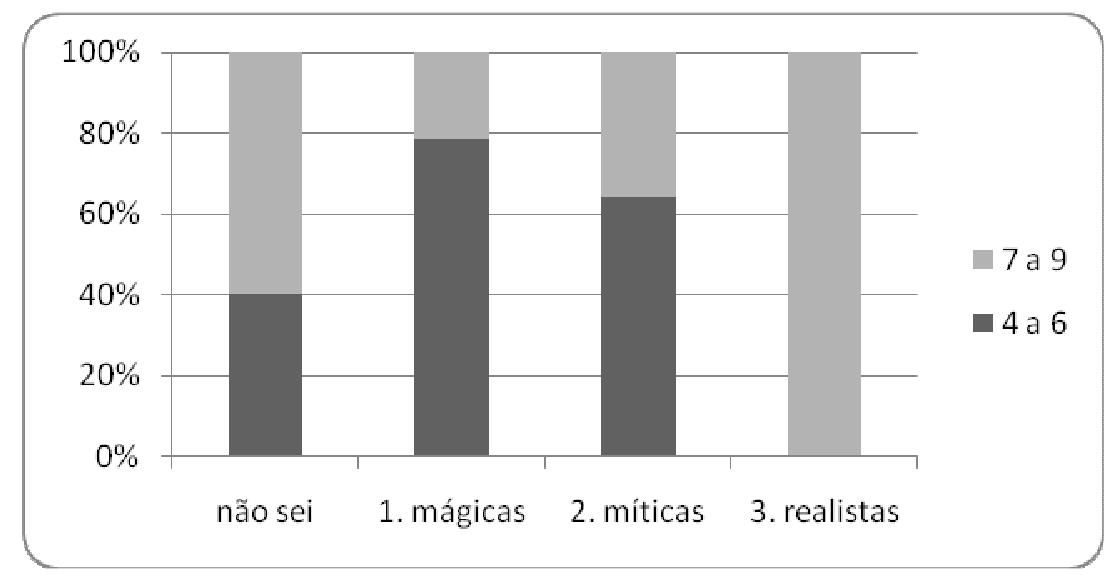

Considerando o total de respostas de cada nível, na figura acima, constata-se a prevalência dos elementos mágicos $(79 \%)$ em contrapartida à ausência de crenças realistas para as crianças mais novas. A maioria das respostas míticas também corresponde a esse grupo de crianças novas. Diferentemente, a totalidade de respostas realistas pertence ao grupo de 7 a 9 anos. Ademais, é importante acrescentar que o percentual de $21 \%$ de crenças mágicas do grupo de 7 a 9 anos deve ser entendida no contexto da educação religiosa, sendo que elas remetem a frases como "a vontade de Deus", "o poder da oração", acompanhadas às vezes de explicitações como "a minha mãe/tia falou que....". Nas crenças míticas do grupo de crianças mais velhas, apenas duas apelam à crença de comida fecundante, enquanto o resto fala de sementes preexistentes, brotinhos, ou bolas que crescem e se desenvolvem. Em linhas gerais, pode-se dizer que, em comparação com as crianças mais novas, as crenças míticas das crianças de 7 a 9 anos são muito mais "realistas" que "mágicas". 
De modo geral, os dados mostram que as crenças sobre a fecundação versaram entre idéias de preexistência e explicações de processos de formação do bebê manifestados em distintos tipos qualitativos de respostas, algumas com início de epigênese. A fecundação é um problema de difícil abordagem, como já foi comentado, não só pelos obstáculos cognitivos que apresenta, mas também pelos afetivos. A cena primordial da relação sexual é de difícil tramitação, mas também a noção da fusão de duas células que se juntam para dar forma a um novo ser.

As crenças sobre a fecundação provocada pela alimentação, de comida ou da semente do pai podem ser entendidas como uma assimilação generalizada do real aos esquemas já conhecidos pela criança, mas também como reminiscências da fase oral. A criança entende que o que entra no corpo, necessariamente passa pela boca como canal de ingresso. Além disso, a criança sabe que a alimentação excessiva provoca o inchamento da barriga.

A hipótese da fecundação via alimentação verificada em algumas das entrevistas da pesquisa foi também corroborada por Jagstaidt (1987) no seu estudo com crianças francesas e suíças e nos registros já mencionados (do próprio Piaget, de Melanie Klein, Jung, etc.). Sendo que no pensamento da criança prevalecem os esquemas de ação já conhecidos, o problema é assimilado de acordo com as suas possibilidades mentais e afetivas. Esta idéia também foi comentada por Freud, entendendo que a criança concebe uma alimentação fecundante como consequiência da teoria cloacal. Se o bebê sai da barriga ao modo da defecação, quer dizer que ele foi incorporado pela boca, da mesma maneira que a comida.

\subsection{Crenças sobre a alimentação intra-uterina: do egocentrismo integral ao artificialismo técnico}

As crenças sobre alimentação intra-uterina contemplaram apreciações sobre uma alimentação que provém da comida ingerida pela mãe, que chega por um tubo ou que simplesmente cai na barriga da mãe onde o bebê abre e fecha a boca segundo sua vontade de comer. Os elementos recorrentes nas respostas foram os seguintes:

- O bebê mama com a boca por um negócio dentro da mãe.

- Pega pedacinhos bem pequenos de comida.

- Há tubos que vão pela cabeça e daí para o estômago.

- Come com um aparelhinho, cano, fiozinho ou corda.

- O bebê abre e fecha a boca. Respira pelo nariz.

- A comida fica descendo e ele sente que é comida. 
A partir da articulação dos elementos do conteúdo das respostas com os conceitos teóricos piagetianos já desenvolvidos anteriormente, foram construídos os níveis das crenças sobre alimentação intra-uterina. Este eixo temático foi construído a partir da Q9 ("Como faz o bebê para comer na barriga?"). O seguinte quadro esquematiza esses níveis:

Quadro 2. Níveis das crenças em relação à alimentação intra-uterina

\begin{tabular}{|l|l|}
\hline $\mathbf{N} 1$ & IRREAIS: O bebê não come nem cresce na barriga. \\
\hline $\mathbf{N} 2$ & $\begin{array}{l}\text { PRÉ-ARTIFICIALISTAS: O bebê come o que a mãe come, } \\
\text { mas não se sabe como. }\end{array}$ \\
\hline $\mathbf{N} 3$ & $\begin{array}{l}\text { EGOCÊNTRICO-ANIMISTAS: Alimento proveniente da mãe } \\
\text { e ingestão por mecanismos egocêntricos. O bebê come da comida } \\
\text { ingerida pela mamãe, pela boca. A comida cai na barriga e o } \\
\text { bebê decide se come ou não, abrindo ou fechando a boca. Pode } \\
\text { apresentar particularidades: ele não tem dentes, tem que ser } \\
\text { sempre comida "amassada" ou ele mama leite dentro da barriga. }\end{array}$ \\
\hline $\mathbf{N} 4$ & $\begin{array}{l}\text { ARTIFICIALISTAS TÉCNICAS: Mecanismos diferenciados e } \\
\text { próprios da vida intra-uterina. Tendência a falar de veias, } \\
\text { fiozinhos, tubos, canos, cordas, cordões, tubinhos de passagem. } \\
\text { Às vezes se menciona o umbigo. }\end{array}$ \\
\hline
\end{tabular}

\section{N1 - Crenças irreais sobre alimentação intra-uterina (nível 1)}

As crenças irreais sustentam a idéia de que o bebê não come e não cresce, ainda que com contradições intrínsecas nas falas das crianças. Alguns exemplos são:

E3 (M 4,8) O que faz o bebê dentro da barriga? Fica quietinho dormindo. Ele come? Não, na barriga não.

E37 (M 4,8) Ele não come. Não come, bebê não. Bebê não cresce. O que faz o bebê dentro da barriga? Ele fica chorando.

E35 (F 5,2) Como come o bebê na barriga? Eu não comia dentro da barriga (...). Ele não come dentro da barriga. Ele fica chorando porque ele quer comer.

E21 (F 5,1) Não come porque não tem comida lá dentro. E se a mãe comer? Não come porque a comida vai estar toda mordida, coisas da mãe, e aí o bebê não vai gostar tanto. Se o bebê comer, aí ele é que quer, né? Como faz? Ele fica... ele não sabe nem pegar e fica assim ( faz o gesto de abrir a boca olhando para cima), então ele não come nada na barriga. 
$\mathrm{Na}$ resposta de E21 observa-se uma contradição (o bebê não come, mas se quiser come) e uma concepção animista que outorga consciência e intenções ao bebê na barriga quando diz que ele "não vai gostar" da comida mastigada e que decide se quer ou não quer comer.

\section{N2 - Crenças pré-artificialistas sobre alimentação intra-uterina (nível 2)}

Entre as crenças de nível pré-artificialista, comprova-se que a criança afirma a idéia de que o bebê come, mas não parece sensível ou preocupada acerca de "como" o faz. No geral, sabe que dentro da barriga o bebê come o que a mãe come, mas não explicita processos. Vejamos alguns exemplos:

E25 (F 6) Como come o bebê na barriga? Não sei, mas ele come. Pode comer carne, por exemplo? Carne, mas carne fria porque senão queima a boquinha dele. E24 (F 6,2) Tudo o que a mãe come o bebê come. (...) Eu acho que a mãe come e depois o bebê come. Como faz para beber? Se a mãe bebe eu acho que o bebê bebe.

E33 (F 6,2) O bebê cresce dentro da barriga? Não. Ele cresce só um pouquinho. Ele cresce um pouco, só que quando é a hora dele sair ele ainda é pequenininho. A mãe ela come e o bebê come, não sei como que o bebê come dentro da barriga da mamãe.

E10 (F 5) Ele está dentro da barriga e demora muitos anos e quando ele come porque o neném fica dentro da barriga, então come a comida que a mamãe come e dentro da barriga dele vai crescendo. Como come? Eu não sei. Porque o bebê não tem dentes ele é banguelinho.

Nas respostas acima citadas, observa-se em E33 uma contradição recorrente: "o bebê não cresce, mas cresce um pouquinho". E25 afirma que não sabe como come, porém, depois diz que o bebê pode se queimar se a comida não está fria (por outro lado, se pode comer carne poderia se inferir que acredita que o bebê tem dentes dentro da barriga). Nestas crenças, assim como nas mágicas da fecundação, se corroboram os "sentimentos de participação" teorizados por Piaget: a criança sabe que a mãe e o bebê estão ligados no processo de alimentação, mas não sabe dar conta de "como". A alimentação da própria mãe tem algo a ver com o bebê na barriga, e inclusive ele pode ter traços específicos (por exemplo, "não tem dentes"), porém, ainda não se consegue dar uma explicação causal para esse fenômeno.

\section{N3- Crenças egocêntrico-animistas sobre alimentação intra-uterina (nível 3)}

As seguintes respostas correspondem ao nível 3 das crenças sobre alimentação e portanto manifestam uma tendência egocêntrica. As crianças aludem ao esquema próprio e já conhecido de comer pela boca, por exemplo, pegando pedacinhos de comida com a mãe: 
E7 $(\mathrm{M} 4,10)(O$ bebê) come dentro da barriga da mãe. Ele come comida. $O$ que come? Hoje eu comi ração. E o bebê como come? Abrindo a boca.

E5 (F 4,8) Dentro da barriga come, depois limpa com a mão dele, depois come o que a mãe comeu. E às vezes a mamãe come e o bebê não consegue pegar. $O$ bebê na barriga tem dentes? Não, só tem dois pequenininhos. Como faz para comer? Ele arranca um pedacinho de nadinha, bem pequeno e ele come.

E1 (F 4,8) a comida desce pela barriga. O bebê abre a boca e come; se ele não quiser ele fecha a boca; e a mamãe ...come.

E11 (F 5,1) A mãe tem que beber leite, aí vai até a boca do bebê. Como chega até a boca do bebe? Tem que deixar cair todo na barriga da mãe.

E13 (M 5,1) As pessoas comem uma coisa, e eles cortam pedacinho para o neném. E ele fica pegando pão na boquinha e colher.

E18 (M 6) Ele (o bebê) mama, até ele tem um negócio dentro da mãe que ele pode mamar, que eu não sei qual que é o nome, e ele mama com a boca.

E19 (M 6,3) Quando ele está brincando alguém fica comendo, fica descendo umas coisas assim, aí ele sente que é comida.

E74 (M 7,3) O que faz o bebê dentro da barriga? Tenta sair. Como come? A minha mãe... (se corrige) as mães comem, corta os pedaços na barriga e depois o bebê come. Depois caem os pedacinhos secos e entram na barriga do bebê. Qualquer coisa come o bebê dentro da barriga? Sim. E se a mãe toma cerveja? O bebê nasce doido.

As crenças de nível 3 são animistas porque as crianças pressupõem que o bebê come se tem fome por meio de processos autônomos e voluntários, como se limpar com a mão depois de comer. E19, por exemplo, dá uma resposta animista outorgando consciência ao bebê que pode "sentir" o que é e o que não é comida. E7 mostra claramente uma linha de raciocínio egocêntrica sendo que o bebê come com a boca e ele se inclui espontaneamente na resposta: "hoje eu comi ração". Em linhas gerais, as crenças deste nível entendem que o bebê come com a boca, que pode pegar comida com as mãos, que a comida desce na barriga em forma de pedacinhos muito pequenos, e até que se pode cortar comida dentro da barriga.

\section{N4- Crenças artificialistas-técnicas sobre alimentação intra-uterina (nível 4)}

Para inferir as respostas do nível 4 resultou pertinente apelar ao estágio piagetiano do artificialismo técnico (interesse da criança pelos detalhes das máquinas e pelos processos da técnica). Pode-se acrescentar que é possível que as crianças do grupo etário de 7 a 9 anos já tenham recebido informação na escola acerca do aparelho digestivo, portanto algumas das respostas poderiam estar influenciadas pelos conhecimentos dos "tubos digestivos". Alguns exemplos são os seguintes:

E61 (M 7,7) A mãe dele come, e aí tem um cano que vai para ele. De que está feito o cano? Não sei. Uma coisa de comer, para entrar comida lá. Para onde vai esse 
cano? Na barriga. Ele vai crescendo, cada dia. Fica melhorando, fica comendo lá e descansando.

E50 (M 8,7) Quando a mãe come, tudo o que ela come vai para o bebê. Como vai? Quando ela mastiga essas coisas, quando ela engole, tem um tubo que vai para o bebê. E o bebê acaba se criando, vai se formando

E75 (M 8,6) É assim, ele vai ter dois canos, aqui. Um cano vai para cá e outro vai para lá. Aí ele come um pouquinho e esse cano fecha. Aí o tubo vai na boca que fica saudável.

E41 (F 8,7) Tem um cano que vai nele e ele come. Onde termina? Acho que na barriga dele, ou na boca. Que come na barriga? A mãe mastiga, bem mastigado, e o bebê come tudo mastigado. Ele não mastiga.

E46 (F 8,1) A mãe mastiga a comida que ela come, e o bebê se alimenta. Tem tipo um fiozinho que fica dentro da barriga, e daí ele se alimenta com essa comida.

E24 (M 6,3) O bebê come dentro da barriga? Come. Quando minha mãe come, dentro da barriga o bebê está dentro da barriga. Eu acho que tem um aparelhinho para ele comer

E73 (M 7) Tem um tubo que vai direto pela cabeça de aí da cabeça vai para o estomago. (...) a mãe come, ela mastiga, daí fica mole, e o que acontece? Vai para o estômago do neném.

A diferença das crianças mais novas que explicavam o desenvolvimento fetal com a expressão "o bebê vai nascendo", tanto E61 como E50, utilizam termos mais específicos como para dar conta do fenômeno (o bebê "vai se criando" "vai crescendo" "vai se formando"). Nas respostas acima, observa-se que as expressões utilizadas pelas crianças para explicar a alimentação intra-uterina contemplaram elementos como: fiozinho, tubo, cano, cordão, corda, pelo umbigo, tubinho de passagem. Na maioria dos casos não se consegue explicar de onde sai esse "tubo", nem até onde chega ou de que está feito. Muitas crianças acrescentam que o bebê pode comer qualquer coisa desde que seja saudável: muita salada, limão, legumes. Segundo Piaget, o período do artificialismo técnico marca o início da aprendizagem do real pelas suas leis renunciando à onipotência humana. A configuração geral das coisas é atribuída ao homem, mas a sua ação se limita às operações tecnicamente realizáveis (Piaget, 1926/2005).

Esse tipo de crenças foi constatado na pesquisa de Jagstaidt (1987), na qual, quando se solicita que expliquem a alimentação intra-uterina, as crianças também se apóiam em vocabulário que remete às máquinas, referindo-se a tubos e canos dentro do corpo humano. A autora afirma que durante esse período, as crianças adaptam certos mecanismos da tecnologia a tudo o que elas encontram e imaginam pela necessidade de exercitar seus novos esquemas de compreensão da técnica. 


\section{Análise quantitativa das crenças sobre alimentação intra-uterina}

A seguir, será apresentada a análise quantitativa das crenças sobre alimentação intrauterina a partir de tabelas e figuras que, contemplando sua distribuição de frequiência absoluta e percentual, revelam as tendências prevalentes de acordo com o grupo etário das crianças.

Tabela 7. Distribuição de freqüência absoluta e percentual das crenças sobre alimentação intra-uterina por grupo etário

\begin{tabular}{cccccc}
\hline & Irreais & $\begin{array}{c}\text { Pré } \\
\text { artificialistas }\end{array}$ & $\begin{array}{c}\text { Egocêntrico } \\
\text { animistas }\end{array}$ & $\begin{array}{c}\text { Artificialistas } \\
\text { técnicas }\end{array}$ & Total \\
\hline $\mathbf{4}$ a $\mathbf{6}$ & $9(22,5 \%)$ & $12(30 \%)$ & $\mathbf{1 7}(\mathbf{4 2 , 5 \% )}$ & $2(5,0 \%)$ & $40(100 \%)$ \\
\hline $\mathbf{7}$ a $\mathbf{9}$ & $0 \%$ & $10(25 \%)$ & $9(22,5 \%)$ & $\mathbf{2 1 ( 5 2 , 5 \% )}$ & $40(100 \%)$ \\
\hline total & $9(11,3 \%)$ & $22(27,5 \%)$ & $26(32,5 \%)$ & $23(28,8 \%)$ & $80(100 \%)$ \\
\hline
\end{tabular}

Figura 4. Distribuição comparativa da freqüiência percentual de cada nível de crença sobre alimentação intra-uterina por grupo etário

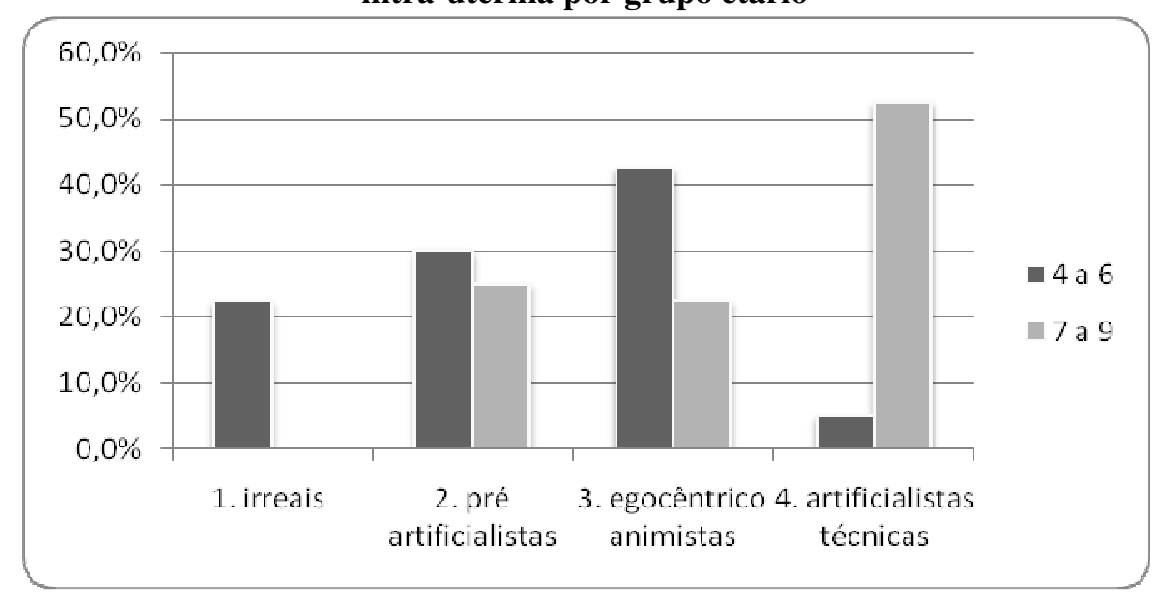

A tabela acima mostra que as crenças irreais (nível 1) são ausentes no grupo etário de 7 a 9 anos, enquanto $22,5 \%$ das crianças de 4 a 6 anos não se mostram sensíveis ao problema da alimentação intra-uterina e diretamente negam o fato, afirmando que o bebê não se alimenta nem cresce dentro da barriga. Os resultados também mostram uma menor proporção de crenças pré-artificialistas nas crianças mais velhas (25\%) em relação às mais novas (30\%), ainda que estas tenham admitido que o bebê se alimenta, não conseguiram dar conta do processo. Isso verifica suas maiores dificuldades para explicar um processo complexo e não observável, que tem que ser inferido se não se recebeu informações do meio. As respostas 
egocêntrico animistas mostram uma maior porcentagem para o grupo etário de 4 a 6 anos $(42,5 \%)$ em relação às mais velhas $(22,5 \%)$, o que responde às linhas gerais do pensamento pré-operatório egocêntrico, entendendo o bebê dentro da barriga como similar a eles mesmos, com capacidade de pegar comida e levá-la à boca. Ao mesmo tempo, a sua baixa porcentagem nas crenças artificialistas técnicas mostra um pensamento menos socializado, porque entender outras formas humanas de comer implica se descentrar para não projetar os próprios esquemas em outros contextos.

Em contrapartida, o grupo de 7 a 9 anos tem maior porcentagem de respostas artificialistas técnicas $(52,5 \%)$ em comparação com as egocêntricas desse mesmo grupo. Esse dado confirma a linha progressiva de uma construção do conhecimento que se torna mais permeável a explicações do entorno social, menos intuitiva, que aceita elementos próprios da natureza (e menos da magia) e que admite processos para além das evidências perceptivas. Apenas dois sujeitos (5\%) entre 4 e 6 anos manifestaram crenças com elementos próprios da alimentação intra-uterina. Em suma, cabe destacar que a maior concentração das crenças das crianças mais novas são de nível 3, enquanto que das crianças mais velhas são de nível 4 . Entre as crianças mais novas, tal como os dados demonstram, a tendência é sustentar crenças egocêntricas e que outorgam consciência e vontade ao bebê, porque ele sente fome e decide comer ou não abrindo e fechando a boca. Estas evidências remetem à hipótese de que as crenças sobre alimentação intra-uterina se correspondem com o pensamento animista e intuitivo, que progressivamente se desenvolverá com características artificialistas, admitindo processos naturais misturados com elementos da tecnologia humana. Para melhor visualização das diferenças das crenças em cada faixa etária, apresenta-se uma figura com a totalidade dos níveis segundo cada grupo.

Figura 5. Distribuição percentual das crenças sobre alimentação intra-uterina em cada grupo etário

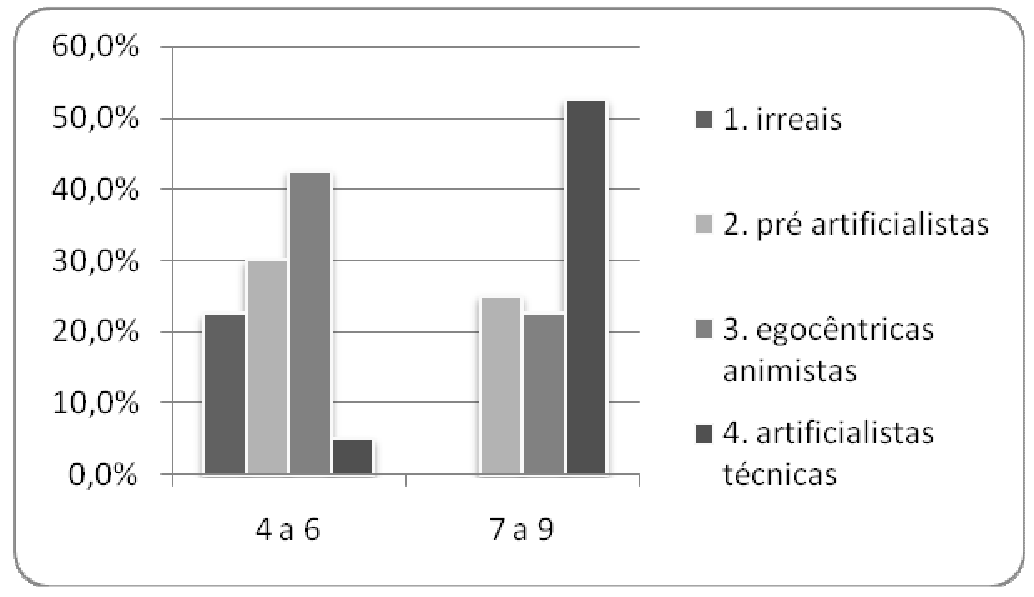


A seguir, apresenta-se a distribuição das respostas segundo o sexo; como foi observado no item em que foi exposto o método, por apresentar uma diferença aparentemente significativa.

Tabela 8. Distribuição de freqüência absoluta e percentual das crenças sobre alimentação intra-uterina por sexo das crianças

\begin{tabular}{cccccc}
\hline Sexo & Irreais & $\begin{array}{c}\text { Pré } \\
\text { artificialistas }\end{array}$ & $\begin{array}{c}\text { Egocêntrico- } \\
\text { animistas }\end{array}$ & $\begin{array}{c}\text { Artificialistas } \\
\text { técnicas }\end{array}$ \\
\hline Masculino & $5(55,6 \%)$ & $8(36,4 \%)$ & $8(30,8 \%)$ & $16(69,6 \%)$ \\
\hline Feminino & $4(44,4 \%)$ & $14(63,6 \%)$ & $18(69,2 \%)$ & $7(30,4 \%)$ \\
\hline Total & 9 & 22 & 26 & 23 \\
\hline
\end{tabular}

Estes dados evidenciam diferenças em relação ao sexo das crianças, especialmente nas crenças do nível 2 ao 4. Do total de crenças pré-artificialistas, 36,4\% correspondem aos meninos e $63,6 \%$ às meninas. Esta diferença é ainda maior se comparamos as crenças egocêntrico animistas e artificialistas técnicas: enquanto das 26 crenças do nível 3, 69,2\% são de meninas; das 23 crenças do nível 4, 69,6\% são de meninos. A partir desse dado só podem ser feitas conjeturas provisórias, já que se trata de um tema que mereceria um aprofundamento que excede os objetivos deste trabalho. Chama a atenção que as crenças de alimentação préartificialistas e egocêntrico-animistas prevaleçam nas meninas. Essas crenças implicam que o bebê pode mastigar, cortar pedaços, sugar sangue e comer o mastigado da mãe. Essas imagens poderiam gerar angústia porque as meninas, segundo a equação simbólica freudiana (pênis = bebê), desejam ter um bebê. Entender a alimentação intra-uterina a partir de crenças egocêntrico-animistas sugeriria a possibilidade de ter uma espécie de "açougue" dentro da sua barriga. Diante deste panorama da prevalência de crenças artificialista técnicas nos meninos, outra hipóteses que poderia ser levantada é se, dado o sexismo que prevalece em muitos contextos sociais, os meninos se interessariam mais que as meninas pela tecnologia e o funcionamento dos aparelhos.

A seguir, será apresentada a tabela e a figura correspondente à análise quantitativa das crenças sobre alimentação intra-uterina em cada nível de crença: 
Tabela 9. Distribuição percentual das crenças sobre alimentação intra-uterina em cada nível

\begin{tabular}{|c|c|c|c|}
\hline Grenças & 4 a 6 & 7 a 9 & Total \\
\hline Irreais & $100,0 \%$ & $0 \%$ & $100 \%$ \\
\hline Pré artificialistas & $54,5 \%$ & $45,5 \%$ & $100 \%$ \\
\hline Egocêntrico-animistas & $65,4 \%$ & $34,6 \%$ & $100 \%$ \\
\hline Artificialistas técnicas & $8,7 \%$ & $91,3 \%$ & $100 \%$ \\
\hline
\end{tabular}

Figura 6. Distribuição percentual das crenças sobre alimentação intra-uterina em cada nível

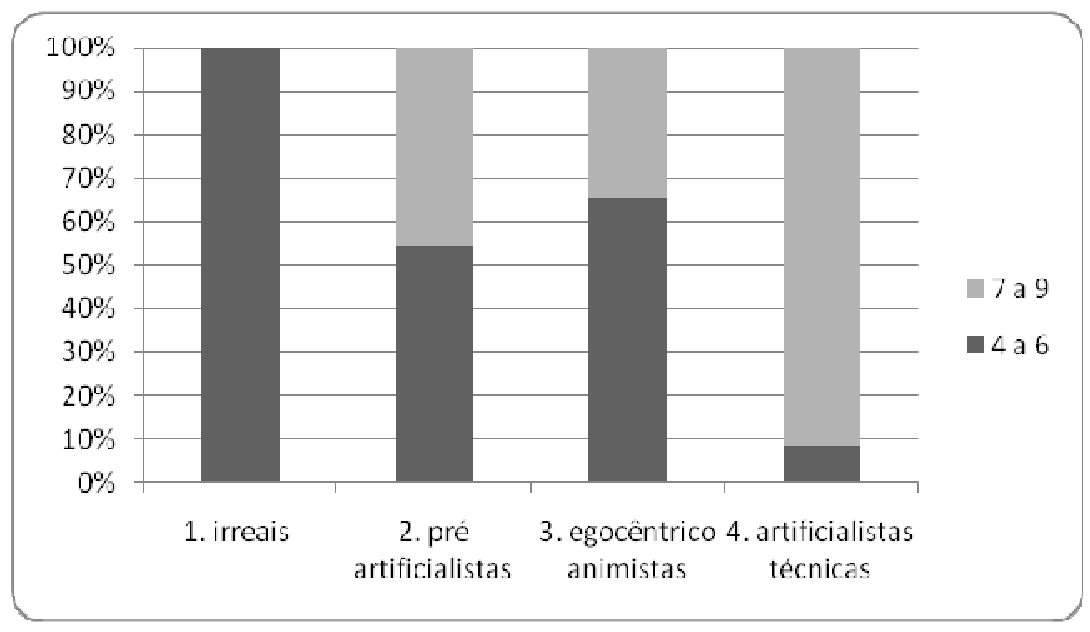

De acordo com a tabela e a figura acima, verifica-se que a totalidade de respostas baseadas em crenças irreais foi dada pelas crianças mais novas. Em segundo lugar, observa-se uma distribuição praticamente similar entre as duas faixas etárias para as crenças préartificialistas. Do total das crenças egocêntricas, mais de $60 \%$ corresponde às crianças mais novas. Por último, vale ressaltar que há uma preponderância aparentemente significativa de crenças artificialistas-técnicas entre as crianças mais velhas.

A respeito da vida intra-uterina, também foi indagado acerca do tempo que o bebê fica na barriga (Q8). Nas crianças mais novas houve prevalência de repostas aleatórias ou difusas como: "13 dias", "muito tempo", "bastante", "um pouquinho", "até que for a hora dele sair", "um monte de minutos". A resposta "9 meses" se concentrou nas crianças mais velhas. Alguns exemplos são apresentados abaixo:

E $6(\mathrm{M} 4,3) 5$ anos.

E15 (F 6,6) Eu acho que uns 20 anos.

E73 (M 7) muito tempo, quase um século.

E58 (M 7,3) Deve ficar, mmm era 9... 9 alguma coisa.... 9 ... 9 meses.

E72 (M 8,9) 5 ou 8 meses. O bebê, ele fica chutando, chutando, muito. Até que chega um ponto que a mãe não agüenta mais e vai para o médico. 
E78 (F 8,6) 9 semanas ou 9 meses. Não lembro.

E52 (F 8,7) Uns nove meses.

As respostas mostram uma melhor adequação à realidade nas crianças mais velhas, ainda que em alguns casos não manifestem consistência na sua noção de tempo. Nas crianças mais novas, pareceria que as respostas ambíguas como "muito tempo" é suficiente para entender o tempo de vida intra-uterina e não manifestam sensibilidade a uma padronização de tempo biológico e universal para todos os seres humanos. A partir de um pensamento mais socializado exprimido pelas crianças mais velhas, o número "9" é dito quase que automaticamente, inclusive antecedido de "a professora falou que fica 9 meses". Contudo, essa afirmação correta "aprendida" a partir de informantes externos não garante que a noção de tempo esteja consolidada. Por último, pode-se verificar que as crianças mais novas, em vez de admitir que não sabem, não tem problemas de "chutar" uma resposta, com muita convicção, a partir de qualquer medida de tempo (de minutos a séculos).

\subsection{Crenças sobre o nascimento: do corte da barriga à consideração da vagina}

Em relação ao nascimento, entendido como a "saída do bebê da barriga", 79 das 80 crianças respondem que o bebê sai da barriga da mulher e 1 da barriga do homem. As crianças mais velhas tendem a responder que o bebê também pode sair pela "perereca", "vagina" ou “outro lugar”. Esses níveis foram construídos a partir da terceira questão (Q3: "Como faz o bebê para sair da barriga?").

Quadro 3. Níveis das crenças em relação ao nascimento

\begin{tabular}{|l|l|}
\hline N 1 & $\begin{array}{l}\text { PRÉ-ARTIFICIALISTAS E DIFUSAS: A criança responde } \\
\text { que o bebê sai da barriga, mas não sabe como. Responde que } \\
\text { alguém "tem que tirar da barriga" ou que o médico tira com } \\
\text { alguma coisa. Sem processos, a passagem de dentro-fora da } \\
\text { barriga não consegue ser explicada. Pré-artificialistas por não } \\
\text { parecer sensíveis ao problema. }\end{array}$ \\
\hline N 2 & $\begin{array}{l}\text { PARCIAIS: A criança contempla só uma via de saída. Sai pela } \\
\text { barriga a partir de cortes (e não tem outro jeito de sair) ou sai só } \\
\text { pela vaina. Podem contemplar justaposição/condensação de } \\
\text { cesariana e parto pela vagina (cortes + fazer força). Contempla } \\
\text { a saída pelo "bumbum" ou "ânus". }\end{array}$ \\
\hline
\end{tabular}




\begin{tabular}{|c|l|}
\hline N 3 & $\begin{array}{l}\text { REALISTAS: Admitem as duas formas de saída. Da barriga } \\
\text { ou de outro lugar. Pode ser a vagina, perereca ou outro lugar } \\
\text { "que não se sabe" ou que não se quer falar. }\end{array}$ \\
\hline
\end{tabular}

\section{N 1 - Crenças pré-artificialistas e difusas sobre o nascimento (nível 1)}

Ainda que não haja prevalência de respostas pré-artificialistas em nenhum dos dois grupos, uma diferença a ser ressaltada é que novamente as crianças mais velhas tendem a responder "não sei” quando não sabem (ou talvez não queiram) responder à pergunta. Diferentemente, as crianças mais novas tendem a dar algum tipo de resposta difusa, omitem o "não sei" e em muitos casos quando o entrevistador pergunta de novo, restringem-se a repetir a mesma resposta já dada. Vejamos alguns exemplos.

E77 (M 8) O médico, ele tira. Como tira? Não sei.

E9 $(F, 5)$ Um médico tira da barriga.

E38 (M 5,4) Eu acho que eu nasci da barriga de meu pai. Você então nasceu da barriga da sua mãe ou de seu pai? Do meu pai.

E2 (F 4,3) Ir no médico. O que faz ele? Toma uma injeção. O bebê ou a mãe? O bebê. Por onde sai? Pela barriga.

E52 (F 8,7) Ele vai no médico e aí nasce o bebê. Como sai da barriga? Não sei.

E36 (M 4,3) Saem na ambulância. Tem que levar para o médico. O médico tira da barriga.

E19 (M, 6,3) Por onde sai o bebê? Na barriga. Mas como sai da barriga? Tem que fazer uns exames aí, com a marca dos exames já sai.

\section{N 2 - Crenças parciais sobre o nascimento (nível 2)}

A respeito das crenças parciais que contemplam uma só via de saída é importante esclarecer que essa via é preponderantemente a cesariana para os dois grupos etários. O resto das crenças se distribuiu da seguinte forma: no grupo das crianças de 4 a 6 anos duas sustentaram a teoria cloacal; no grupo de crianças de 7 a 9 anos, 4 manifestaram a justaposição/condensação do parto pela vagina e cesariana e 1 afirmou que o bebê só sai pela vagina. Vejamos os exemplos a seguir:

E50 (M 8,7) Os médicos o tiram. Como? Bem primeiro abrem a barriga, logo puxam ele. Tem outro jeito de sair? Não.

E22 (M 4) Ele sai por aqui (assinala a bunda). Como se chama isso? Minha irmã só fala que é ânus. Tem que ir para o médico para tirar. Como faz o médico para tirar? Tem que puxar. Primeiro puxa a cabeça, depois o braço, o outro braço e aí as pernas.

E54 (M, 9) Eles cortam um negócio aqui, daí eles falam para a mulher fazer força. E aí o bebê sai. Tem outro jeito de sair? Não.

E53 (F 8,8) Eles cortam a barriga, depois eles pegam o bebê. Tem outro jeito de sair? Não sei. 
E72 (M 8,9) Tem que ir no médico, tem que cortar e tirar. Com que corta? Com a tesoura. Tem outro jeito de sair? Não. Se cortar de um lado sai de um lado, se cortar do outro sai do outro. Se cortar do meio sai do meio.

E13 (M 5,1) Cortam na barriguinha e depois nasce o bebê. E daí costura.

E31 (M 5,8) Quando uma mulher está muito, muito gorda e grávida, quando ela estiver chorando aí leva para o hospital e tira o neném. Quem tira? O médico. Pega a tesoura, a faca, corta a barriga e tira o bebê. Só cortar aqui (assinala a garganta), pega o bebê, e aí fica com o neném. Corta aqui. $\mathrm{O}$ médico enfia a mão e pega o neném. (...) Corta a barriga, tira o bebê e deixa ele vivo.

As afirmações acima apresentam algumas particularidades relacionadas com os conceitos teóricos já desenvolvidos. Por um lado, a crença exprimida por E22 lembra a teoria cloacal postulada por Freud. Resulta bem interessante que E22 sustente essa idéia mesmo que tenha recebido informação sobre a origem dos bebês (da sua mãe e tia), e manifesta um vocabulário bem específico a respeito disso (por exemplo, acerca da alimentação intra-uterina diz: "Ele tem o cordão umbilical e aí deita com o cordão umbilical", sendo um dos poucos entrevistados que soube nomear o cordão dessa forma). Isto parece indicar que a assimilação infantil das informações prevalece por mais que a criança receba boas informações a respeito do tema e, portanto verifica as teorias piagetiana e freudiana.

Por outro lado, E54 justapõe a cesariana com o parto vaginal, condensação que também foi constatada em outras entrevistas. No caso de E31, ele faz uma descrição do nascimento que lembra a idéia teorizada por Abraham da cesariana como uma operação sangüenta que reedita a castração nas mulheres (cf. 3.6). Além disso, E31 evidencia não assimilar a relação causa (gravidez) - efeito (estar gorda), sendo que as duas condições são consideradas como estados sem relação causal: a mulher está "gorda e grávida".

\section{N 3 - Crenças realistas sobre o nascimento (nível 3)}

As crenças realistas contemplam duas formas de saída do bebê. Essa idéia se manifesta em diferentes níveis de explicitação, sendo que a vagina parece ser um termo que envolve conflitos tanto cognitivos como afetivos. Só em duas entrevistas se apresentam elementos explicativos que lembram à dilatação. Alguns exemplos estão transcritos logo abaixo:

E49 (F 8,7) Como sai o bebê da barriga? Pela barriga ou pela parte íntima. E46 (F 8,1) Uns saem da barriga. E outros? Você já sabe.

E15 (F 6,6) Têm alguns que nascem da barriga que cortam e têm alguns que nascem da perereca que se vai abrindo, abrindo, abrindo ate que sai (faz o gesto com a mão). Sai sozinho ou precisa de ajuda para sair? (pensa)... Agora está difícil de responder.

E51 (F 8,10) Fazem força e o bebê sai. Por onde? Por aqui (assinala entre as pernas). Só pode sair por aí? Não. Cortam a barriga e o bebê sai. 
E58 (M 7,3) A mãe faz uma força e aí o bebê sai, por aqui embaixo (assinala entre as pernas). Lembra como se chama por aí embaixo? Não. Minha mãe já falou várias vezes, mas eu esqueci. Tem outro jeito de sair? Sim, cortando a barriga.

E 60 (M 9) Fazem um corte na barriga e sai o bebê. Tem outro jeito de sair? Sim, pela vagina também sai.

E64 (F 7,6) Cortam a barriga. Os médicos. Tem outro jeito de sair? Não sei. (pensa e assinala entre as pernas e pergunta) Dá para sair por aqui? Pela bexiga? (em vez de vagina).

E 55 (M 9) A mãe... (pensa) tem dois jeitos de fazer. Uma é força para sair por outra parte. E eles cortam a barriga e tiram. Como é por outra parte? Por outra parte ela fica forçando para sair.

E68 (F 7,6) Ou corta a barriga da mãe ou sai pela perereca.

E16 (F 6,2) Acho que nos humanos eles nascem cortando a barriga ou escorregando pela periquita.

A teoria cloacal em ocasiões também aparece para explicar o nascimento dos filhotes de cachorros. Algumas crianças que apelaram a Deus ou Jesus para explicar a fecundação humana podem estender esse esquema à fecundação dos cachorros. Algumas das respostas para a pergunta Q5 (“Como nascem os filhotes dos cachorros?”) foram:

E6 (M 4,3) Saem pelo bumbum, sai pela boca. Pela boca ou pelo bumbum? Sai pela boca.

E20 (F 6,6) É meio complicado dizer isso. Eu acho que a mamãe faz muita força e saem (...). Quando a mamãe faz forte.

E21 (F 5,1) Eu não sei como é que eles nascem (pensa) será que eles são pequenininhos quando eles nascem e saem pela boca?

E5 (F 4,8) Ela (a cachorra) faz cocô e depois sai por aqui. Por onde? Pela barriga. Mas por que primeiro tem que fazer cocô? Ela está com dor de barriga, ela come, fica com dor de barriga faz, depois o cachorro fica na barriga, depois fica com muita dor e abre sozinho assim. Onde estavam antes de estar na barriga? Tava no rabo, depois ela fez cocô, grudou no cocô e foi lá para a barriga.

E25 (F 6) Pelo bumbum da mãe deles. Como entram? (pensa) Acho que Jesus põe dentro da barriga e aí o dono do cachorro descobre.

E38 (M 5,4) Como nascem os cachorros? Eles nascem dentro da barriga. Como aparecem dentro? Não sei, acho que Deus leva os filhotes e aí pelo poder dele fica. Como faz para colocar dentro? Acho que pelo poder dele.

Nas respostas acima, chama a atenção a explicação sobre o nascimento dos filhotes "pela boca". Essa possibilidade foi contemplada para os bebês humanos tanto por Freud como por Piaget, porém, nesta pesquisa não foi verificada para explicar o nascimento das pessoas. Esta crença do nascimento dos animais pela boca também foi corroborada na pesquisa de Jagstaidt (1987). Vale também assinalar que tanto E25, como E5 e E6 apelam a teorias cloacais. Ela também poderia ser inferida em E20 por não mencionar por onde saem especificamente os filhotes, mas sim que a mãe "tem que fazer força". Por outra parte, para 
E25 e E38 a figura de Jesus ou Deus também pode participar na fecundação dos animais, assim como nos humanos. E38 também manifesta a homologação da palavra nascer = fecundar: "eles nascem dentro da barriga".

\section{Análise quantitativa das crenças sobre o nascimento}

Os dados coletados permitiram a realização das seguintes tabelas e figuras que mostram as tendências na construção do conhecimento sobre o nascimento dos bebês:

Tabela 10. Distribuição de freqüência absoluta e percentual de cada nível de crença sobre o nascimento por grupos etários.

\begin{tabular}{ccccc}
\hline Grupos etários & $\begin{array}{c}\text { Pré-artificialistas } \\
\text { e difusas }\end{array}$ & Parciais & Realistas & Total \\
\hline $\mathbf{4}$ a $\mathbf{6}$ & $8(20,0 \%)$ & $\mathbf{2 9 ( 7 2 , 5 \% )}$ & $3(7,5 \%)$ & $40(100,0 \%)$ \\
\hline $\mathbf{7}$ a $\mathbf{9}$ & $7(17,5 \%)$ & $15(37,5 \%)$ & $\mathbf{1 8 ( 4 5 , 0 \% )}$ & $40(100,0 \%)$ \\
\hline Total & $15(18,8 \%)$ & $\mathbf{4 4}(\mathbf{5 5 , 0 \% )}$ & $21(26,3 \%)$ & $80(100,0 \%)$ \\
\hline
\end{tabular}

Figura 7. Distribuição comparativa da freqüência percentual de cada nível de crença sobre nascimento por grupos etários

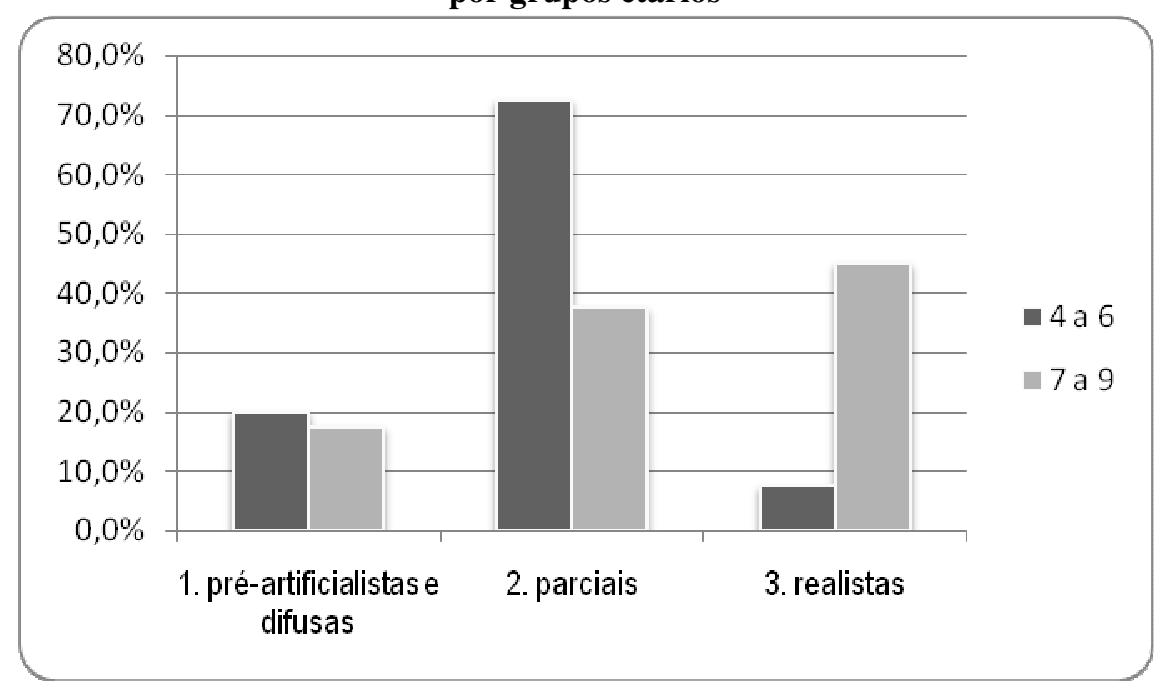

A tabela acima mostra uma distribuição similar das crenças pré-artificialistas e difusas entre os dois grupos etários. As crenças que prevalecem nas crianças mais novas correspondem a crenças parciais, já que 37,5\% das crianças mais velhas respondem a partir deste nível e 72,5\% das crianças de 4 a 6 anos explicam a saída do bebê a partir de uma única possibilidade: cortar a barriga (27 crianças) ou pelo ânus (2 crianças). Vale assinalar que das crenças parciais das crianças mais velhas (15), 10 afirmam que o bebê sai cortando a barriga, 
4 explicam o nascimento mediante a fusão de cortar e fazer força, e somente 1 contempla a saída pela vagina. Esses resultados confirmariam a idéia freudiana de que explicações infantis de cortes da barriga, "ao modo de Chapeuzinho Vermelho", sucedem à teoria cloacal, resultado da ignorância da função reprodutora da vagina (Freud, 1908/1996). As crianças mais velhas concentram as crenças realistas. Enquanto 22 crianças de 7 a 9 anos (45\%) explicam o nascimento a partir de crenças realistas, apenas 3 crianças de 4 a 6 anos $(7,5 \%)$ manifestaram crenças desse nível. Desse modo, nota-se uma inversão na tendência às crenças parciais e realistas segundo o grupo etário: enquanto as crianças mais novas concentram as respostas baseadas em crenças parciais, as crianças mais velhas concentram as crenças realistas. Essas diferenças são mais evidentes se são observadas em conjunto para cada grupo etário:

Figura 8. Distribuição percentual dos níveis de crenças sobre nascimento, em cada grupo etário

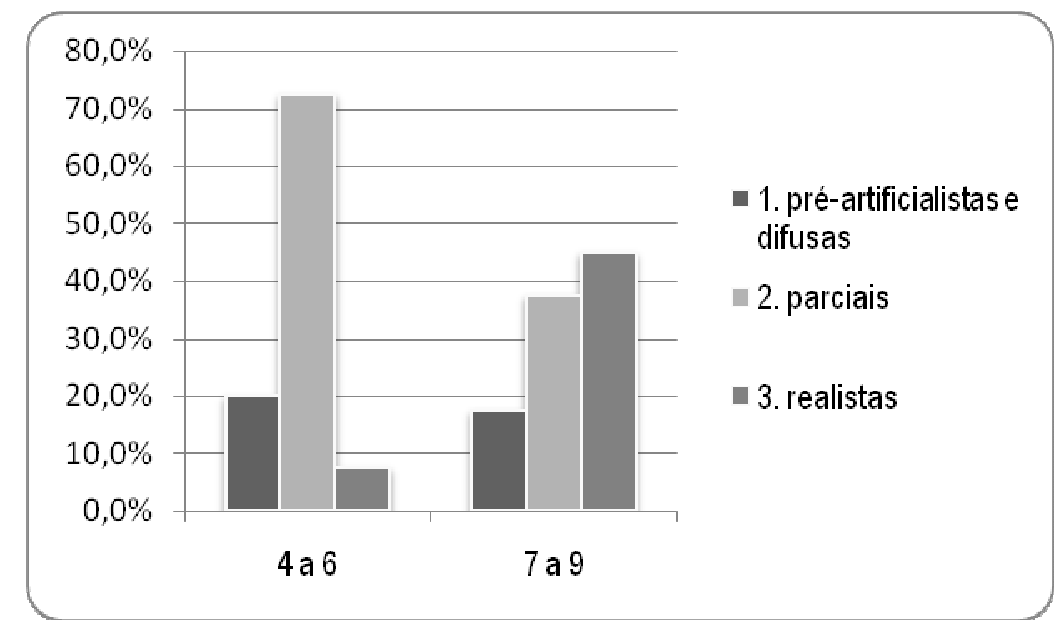

Vejamos, a seguir, como se distribuem os grupos etários segundo o total de cada nível de crença sobre o nascimento:

Tabela 11. Distribuição percentual de cada nível de crenças sobre nascimento

\begin{tabular}{cccc}
\hline Grupo etário & $\mathbf{4}$ a 6 & $\mathbf{7}$ a 9 & Total \\
\hline $\begin{array}{c}\text { Prenças } \\
\text { e difusas }\end{array}$ & $53 \%$ & $47 \%$ & $100 \%$ \\
\hline Parciais & $66 \%$ & $34 \%$ & $100 \%$ \\
\hline Realistas & $14 \%$ & $\mathbf{8 6 \%}$ & $100 \%$ \\
\hline
\end{tabular}


Figura 9. Distribuição percentual de cada nível de crença sobre nascimento

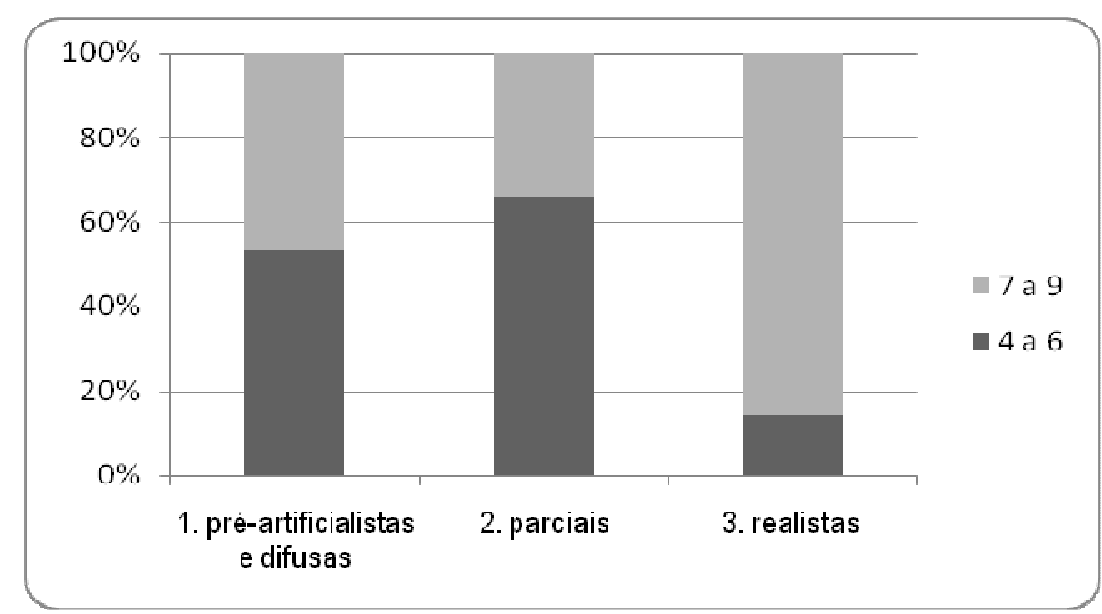

Os dados acima revelam, inicialmente, que não há diferenças substantivas entre na distribuição das crenças pré-artificialistas e difusas crianças mais novas (53\%) e mais velhas (47\%). As crianças de 4 a 6 anos concentram (66\%) as respostas dos níveis 2, sendo que suas respostas contemplam somente a saída do bebê via cesariana. Contrariamente, as crianças mais velhas concentram as crenças realistas (86\%). A partir da distribuição dos três níveis de crenças das crianças mais velhas, há uma tendência progressiva de aumento de adequação à realidade. Entre as mais novas observa-se um crescimento do nível 1 para o nível 2, mas logo uma baixa freqüência das respostas enquadradas no nível 3. Em outras palavras, o grupo das crianças velhas mostra uma tendência crescente em direção às crenças realistas, enquanto que as mais novas evidenciam uma concentração nas crenças parciais.

\subsection{Crenças sobre diferenças sexuais: do gênero à anatomia}

Para abordar as crenças sobre as diferenças sexuais, as respostas das crianças foram organizadas em três níveis, baseadas nas questões 15, 16 e 17: Q15 - "Como se sabe se os bebês dentro da barriga são meninos ou meninas?" (Dependendo da resposta da criança, se era muito ambígua ou confusa: "Qual é a diferença entre meninos e meninas?”- Q16: "Se um menino quer virar menina pode? (Caso responda “não"): E se brinca de bonecas, deixa o cabelo longo e usa vestido?"; Q17 - "Se uma menina quer virar menino pode? (Caso responda “não”): E se brinca de carrinhos, corta o cabelo e usa sempre calça?”).

Quadro 4. Níveis das crenças em relação às diferenças sexuais

\begin{tabular}{|c|c|}
\hline N 1 & $\begin{array}{l}\text { DIFUSAS. As diferenças sexuais estão relacionadas com } \\
\text { situações ambíguas e confusas como a ordem de nascimento ou o }\end{array}$ \\
\hline
\end{tabular}




\begin{tabular}{|c|c|}
\hline & $\begin{array}{l}\text { progenitor que cuida do bebê. A diferença pode ser escolhida a } \\
\text { partir da fala do médico, de pedir a Deus ou pelo desejo dos pais. } \\
\text { A criança não se mostra interessada em aprofundar sua } \\
\text { explicação. }\end{array}$ \\
\hline N 2 & $\begin{array}{l}\text { ESTEREOTIPADAS. Baseadas no gênero e em diferenças não } \\
\text { sexuais: cabelo, roupa, atividades, na cara, no nome etc. No geral } \\
\text { são "não conservadoras" porque ao mudar esses acessórios o } \\
\text { sexo pode mudar. }\end{array}$ \\
\hline N 3 & $\begin{array}{l}\text { REALISTAS. As diferenças sexuais estão baseadas na } \\
\text { anatomia, portanto geralmente são conservadoras. A diferença } \\
\text { pode ser: com menção dos órgãos genitais ou a partir de } \\
\text { caracteres secundários como o peito. }\end{array}$ \\
\hline
\end{tabular}

A respeito de crenças conservadoras e não conservadoras foi tomada da pesquisa de Kohlberg sobre a constância de gênero, que, como já foi desenvolvido (cf. item 2.5) entende que a construção da identidade sexual é uma construção interna que acompanha a evolução das capacidades intelectuais. Segundo Kohlberg (1966), a criança se tornaria sexuada a partir dos 6 ou 7 anos (o que estaria em correspondência com a dissolução do complexo de Édipo). Ainda que sua teoria não seja foco desta pesquisa, ela auxiliou para especificar perguntas e contra-sugestões quando as respostas sobre as diferenças sexuais intra-uterinas não resultavam claras. A seguir serão apresentados exemplos de cada nível de crenças sobre diferenças sexuais, onde este conceito será retomado.

\section{N 1 - Crenças difusas sobre as diferenças sexuais (nível 1)}

As crenças deste nível não utilizam critérios nem de gênero nem sexuais para explicar as diferenças de sexo. Vejamos alguns exemplos:

E3 (M 4,8) [Os bebês] são diferentes e um pouco iguais. Porque deixa o cabelo crescer e são todos iguais. E nos bebês, as meninas são carecas e parecem um homem.

E2 (F 4,3) Menina nasce primeiro que o menino.

E5 (F 4,8) Se ela [a mãe] teve dois, o pai vai ter que cuidar do menino e a mãe vai ter que cuidar da menina. É o anjinho que escolhe se o bebê vai ser menina ou homem.

E24 (F 6,2) Só pelo nome. A minha mãe me deu o nome de X e a minha irmã de Y. Ela pediu para Deus que fossem duas meninas, aí Deus deu eu e a minha irmã. $E$ como fez para saber que tinha uma menina na barriga? Porque ela sabia que ela queria menina... eu acho... Se for menino, compra roupa de menino. Se for menina compra roupa de menina.

E9 (F 5) Q15 Como se sabe se os bebês dentro da barriga são meninos ou meninas? Antes, eu pensava que as meninas nascem da barriga da mamãe e os 
meninos da barriga do papai. E agora o que você pensa? Eu acho que todos os bebês nascem da barriga das mamães.

E19 (M 6,3) Quando alguém quer ter uma menina, nasce uma menina. Quando alguém está com vontade de ter um filho, aí tem um filho. Qual é a diferença entre um menino e uma menina? Que não podem nascer dois. Pode nascer um primeiro e depois vem o outro.

E18 (M 6) Basicamente é igual o corpo da menina e do menino, quase. Por que quase? É que o tamanho da barriga é quase do mesmo tamanho que o menino, então isso explica. A diferença é que... os meninos nascem primeiro e depois as meninas que saem em segundo (...). Basicamente a mudança é que a mãe não sabe quando vai ser menino ou menina então, o corpo sabe se vai nascer menino ou menina. O corpo da mãe? Sim. E o pai como sabe? É que ele não sabe direito. O pai sabe que do corpo dele não nasce bebê, então quer dizer que ele não sabe se vai nascer um menino ou uma menina. Essa que é a explicação.

Das citações acima, pode-se destacar que E19 argumenta pré-causalmente sendo que a vontade humana é suficiente para ter menino ou menina. Ademais, propõe que não podem nascer juntos menino e menina e a sua diferença é argumentada a partir da ordem do nascimento. E18 (M 6) também utiliza o argumento ordinal para explicar as diferenças sexuais. A sua insistência na idéia de que a diferença sexual está baseada na ordem do nascimento talvez se deva a sua própria experiência familiar, sendo que ele só tem um irmão mais novo menino, portanto no futuro poderia nascer uma menina. Ele diz: "É que o corpo da minha mãe sabia que ia nascer primeiro eu. Então é isso. Então o corpo dela sabia de novo que era um menino que vai nascer, meu irmão". Vale ressaltar que E18 propõe uma dissociação mente-corpo, sendo que "o corpo da mãe sabe", mas "a mãe não sabe". Ademais, pode-se assinalar que ao longo da entrevista, E18 manifesta afirmações como "essa que é a explicação", "então isso explica" e "basicamente" com muita convicção como se sua fala fosse bem explicativa e estivesse deixando claro para o interlocutor suas explicações.

\section{N 2 - Crenças estereotipadas sobre as diferenças sexuais (nível 2)}

As explicações das crianças acerca das diferenças sexuais que conformam o nível 2 de crenças remeteram a elementos estereotipados de gênero (especialmente o cabelo) para explicar as diferenças sexuais. Vejamos alguns exemplos:

E12 (F 5) A menina mulher tem cabelinho. E o bebê menino? (...) É diferente, alguns tem cabelo sem cabelo. Qual é a diferença entre meninas e meninos? Brincar com brinquedinhos pequenos, a menina brinca com a Mônica e o menino com Cascão e com Cebolinha. Os meninos usam short, camisa...

E9 (F 5) Não sei... Será que a menina nasce com um pouco de cabelo e o menino nasce careca? 
E42 (M 9) Nascem iguais, mas vai ficando diferente e uns compram roupa de menino porque é menino e outros compram roupa de menina porque é menina. E aí eles se vestem e ficam diferentes.

E50 (M 8,7) O menino ele é mais... a gente brinca de corrida na escola, pega-pega, monte de coisas, bola. Se uma menina quer ser menino tem que fazer coisas de menino, e se um menino quer ser menina tem que fazer coisas de menina.

E73 (M 7) Uns que têm cabelo enroladinho, que é menina, e uns que é careca que é menino. Qual é a diferença entre meninos e meninas? Eu me dou conta pela voz, pela roupa, pela calça, pelo cabelo e pela orelha

E62 (M 7,6) Não sei. E quando nascem? Quando eles nascem o cabelo fica diferente e a voz também. (...) Q16: Eu acho que sim, se usa vestido de homem. $E$ um homem? Sim, pode, põe uma peruca e se veste de mulher. E vai poder ser mãe? Não sei.

E10 (F 5) A menina usa calcinha e o menino usa cueca.

E53 (F 8,8) Se um menino quer virar menina pode? Pode. É só se achar menina. A maioria das meninas não gosta de jogar futebol. Se jogar com carrinho não vira menino. Se a menina cortar o cabelo muito curto ela vira menino. E se o menino usa vestido vira menina? Se usar vestido sim.

E34 (M 6) Menino brinca com menino e menina brinca com menina.

E21 (F 4,10) Menina usa roupa de menina e faz coisa de menina e menino usa roupa de menino e faz coisa de menino.

As crenças acima citadas baseiam as diferenças sexuais pelas brincadeiras, a roupa, o modo de usar o cabelo. Conseqüentemente, a constância de gênero não pareceria estar consolidada sendo que o sexo pode mudar segundo as coisas que se fazem (como afirma E50) ou segundo o cabelo e a roupa (E53).

\section{N 3 - Crenças realistas sobre as diferenças sexuais (nível 3)}

As crenças realistas contemplaram fatores anatômicos como os órgãos genitais e o peito. Em algumas respostas aparecem elementos argumentativos como: cirurgias, adoção, etc. Contudo, cabe ressaltar que, tal como pode ser observado nas seguintes afirmações, algumas crianças manifestaram muita resistência para nomear os órgãos genitais, mostrando às vezes vergonha ou desconforto.

E51 (F 8,10) Qual é a diferença entre um bebê menina e menino? É que a menina tem aquele negócio e o menino tem aquele. Como se chamam? (pensa e ri) Periquita e pinto.

E22 (M 4) O xixi! Como assim? Ué, é que nas meninas os ovinhos são para dentro e nos meninos são para fora. (...) a minha irmã é mais velha. Quando faço xixi com a minha irmã eu vejo. Qual é a diferença? O ovário! É assim, é a parte do nosso corpo dentro de nós. Os das mulheres são para fora e dos homens são para dentro. Alguém falou isso para você?? A minha mamãe. 
E43 (M 8,1) Os meninos são meio diferentes. As meninas nascem com o cabelo meio enroladinho. Os meninos não nascem com muito, muito cabelo. Tem outra diferença no corpo as meninas e meninos? Não (pensa). Não acho que tenha outra diferença no corpo. Só o peito (ri).

E68 (F 7,6) O médico olha com um negócio tipo um telescópio, ele consegue olhar dentro da barriga. Ele vê se tem pipi ou perereca.

E56 (F 9) Se for menino ele tem o... aquele negocinho. Se for menina ela tem a perereca.

E41 (F 8,7) A gente percebe por causa do cabelo ou da perereca, e o menino tem pintinho e cabelo bem curtinho.

E45 (F 9) Acho que é a perereca ou o pirulim (ri).

E46 (F 8,1) Quando ela vai no hospital, aí tem um negocinho que vai na barriga para ver o sexo. Qual é a diferença entre menino e menina? Ah. Não quero falar.

E15 (F 6,6) Eu acho que... Eu já sei, eu sei quando os bebês são meninos e meninas; quando tem perereca e quando tem pipi.

E33 (F 6,2) Primeiro (o médico) vê onde faz xixi. Porque daí é diferente, aí pode saber que é. O dos homens é maior e dos meninas é menor.

E48 (F 8,9) Eles vão ao médico. Daí o médico dá massagem dentro da barriga dela. $\mathrm{E}$ aí eles vêm. Que tem que ver? O pintinho (com vergonha). E se é menina? Não tem. Não tem nada? Só tem... me parece que não. Qual é a diferença entre meninos e meninos? A menina consegue ter filhos e o menino não (...). Alguns nascem diferentes, com problemas.

Tanto E51 como E59 nomeiam os órgãos genitais como "aqueles negocinhos". E46 responde que não quer falar sobre as diferenças, ainda que já tivesse apontado que estava no sexo. A resposta de E41 evidencia uma mistura de crença realista e estereotipada. Ele menciona a diferença genital, porém esta não parece ter ainda o caráter de necessidade lógica porque o cabelo também constitui um critério de diferenciação. Cabe ressaltar a afirmação de E33 que indicaria uma diferença sexual a partir do tamanho de "onde faz xixi", o que confirma a teoria falocêntrica de Freud. Nessa mesma linha, no caso de E48, ela escolhe o pênis como referência para explicar as diferenças sexuais, afirmando que a menina não tem pintinho, mas que pode ter filhos, o que lembra a equação simbólica freudiana "pênis = bebê". No final das respostas sobre o tema, E48 parece querer negar a diferença sexual deslocando-a para uma diferença de saúde: "alguns nascem diferentes, com problemas".

A resposta de E22 assinala uma diferença anatômica, mas como já foi mencionado por Freud, só aponta aos órgãos genitais como diferenciais para fazer xixi. Em nenhum momento de sua entrevista ele menciona o pênis ou a vagina e menciona direitamente os ovários e testículos (implicitamente) reproduzindo assim a fala da sua mãe. Ele afirma que quando faz xixi com sua irmã mais velha ele vê, mas segundo a sua explicação, os dois teriam o mesmo órgão (“o ovário") que nele está para fora e nela está para dentro. É provável pensar essa 
afirmação como outra versão da teoria falocêntrica, sendo que não há órgãos específicos para cada sexo, mas uma localização diferente. Isto também é compatível com sua explicação sobre fecundação via alimentação ("é só comer"). Com isso, é possível inferir que para E22 os genitais ainda não são vinculados causalmente à fecundação, e tal como afirma Freud, é bem distante dele a compreensão da penetração, da função da vagina e do sêmen.

A respeito da constância de gênero, são apresentados brevemente alguns exemplos de crianças que mostrariam indícios de ter consolidado a idéia de que a diferença sexual não muda pelo aspecto exterior, por exemplo, com acessórios, e só seria possível a partir de uma cirurgia:

E68 (F 7,6) Uma menina pode virar menino? Não, mas pode vestir roupa de menino, cortar o cabelo com negócio de menino. Pode fazer igual a menino. Mas não pode mudar.

E56 (F 9) Se um menino quer virar menina ele pode? Poder pode. Como faz? (pensa) Meu pai diz que ele [o menino] faz uma plástica no peito, e aí, o resto não sei mais.

E60 (M 9) Duas mulheres podem ter um bebê?? Não. E um homem sozinho? Ele pode adotar.

E79 (F 7,5) Uma menina pode virar menino? Não, porque ela já tem a sangue de menina. E um menino pode virar menina? Não, porque também já tem sangue de menino.

E59 (F 8,7) Se um menino quer virar menina ele pode? Pode virar gay. A gente chama de gay isso. Meninos que querem virar meninas ou meninas que querem virar meninos. Dentro da barriga, quem decide se vai ser menino ou menina? Não sei... o instinto, acho.

E63 (M 7,5) Se uma menina corta o cabelo e brinca de carrinho, vira menino? Não pode. Por quê?? Porque não dá para trocar. E um menino? Não pode também, por causa da mesma coisa. Ainda que pareça menina não muda.

E66 (F 8,4) Um menino pode virar menina? Acho que não. Não, continua sendo menino porque ele não tem como ter vagina. Se ele quiser fingir de menina, até pode.

Na mesma linha da pesquisa de Kohlberg, os entrevistados E63 e E66 apontam que ainda que a aparência mude não se muda de sexo. Ou seja, as pessoas podem mudar a roupa e as atividades típicas e em consequiência parecer do sexo oposto, mas a situação fica no plano do "fingir". Além disso, vale ressaltar que na afirmação de E59, observa-se uma explicação que tenta dar conta da formação sexual diferenciada do bebê dentro da barriga a partir de um elemento da biologia (o instinto) que aponta o determinismo físico, bem distante das intenções dos pais ou de Deus. 


\section{Análise quantitativa das crenças sobre diferenças sexuais}

A seguir, as crenças sobre as diferenças sexuais serão analisadas quantitativamente em tabelas e figuras.

Tabela 12. Distribuição comparativa da frequiência absoluta e percentual das crenças sobre as diferenças sexuais por grupos etários

\begin{tabular}{cccccc}
\hline Grenças & Não sei & Difusas & Estereotipadas & Realistas & Total \\
\hline 4 a 6 & $13(32,5 \%)$ & $8(20,0 \%)$ & $11(27,5 \%)$ & $8(20 \%)$ & $40(100 \%)$ \\
\hline 7 a 9 & $5(12,5 \%)$ & $0 \%$ & $12(30 \%)$ & $23(57,5 \%)$ & $40(100 \%)$ \\
\hline Total & $18(22,5 \%)$ & $8(10 \%)$ & $23(28,8 \%)$ & $31(38,8 \%)$ & $80(100 \%)$ \\
\hline
\end{tabular}

Figura 10. Distribuição comparativa da freqüência percentual das crenças sobre as diferenças sexuais por grupos etários

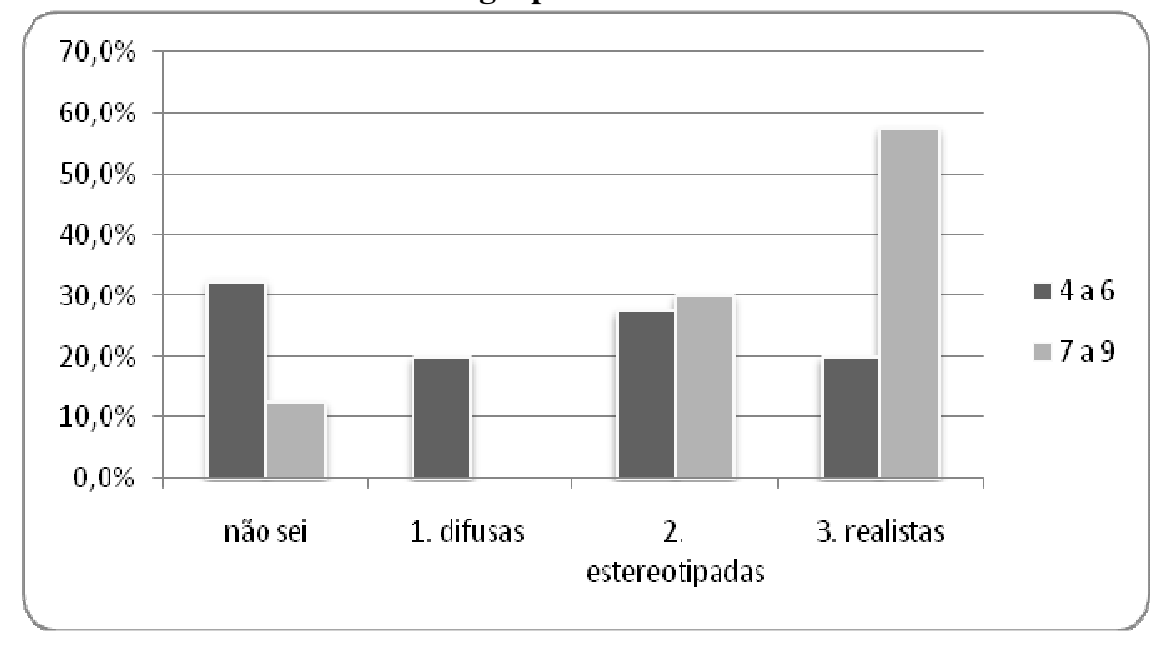

Conforme os dados da tabela e da figura acima, primeiramente nota-se que não há presença de crenças difusas nas crianças mais velhas, enquanto entre as mais novas representam 20\% das respostas. Comparando-se os percentuais das crenças estereotipadas de ambos os grupos, verifica-se que, aparentemente, não há uma grande diferença (27,5\% e 30\%, respectivamente). Estes resultados confirmariam os pressupostos freudianos (cf. item 3.5) acerca da concepção infantil das diferenças sexuais na fase fálica e os "diques de asco e vergonha" próprios do período de latência. Em contrapartida, a figura mostra ainda que parece haver diferenças significativas em relação aos percentuais das crenças realistas (nível 3) de ambos os grupos (26\% para o de 4 a 6 anos e $74 \%$ para o grupo de 7 a 9 anos). Essa 
discrepância confirmaria a possibilidade de uma concepção conservadora das diferenças sexuais entre as crianças mais velhas, o que de acordo com as pesquisas de Kohlberg (1966), corresponde à consolidação da noção de conservação da substância nas crianças de pensamento operatório concreto. Na perspectiva psicanalítica, os dados estão em conformidade com as características da dissolução do complexo de Édipo e a prevalência do princípio de realidade no contexto do início do período de latência.

Os percentuais das respostas "não sei" e das crenças difusas das crianças mais novas somam 52,5\%, em contraste com 12,5\% das crianças mais velhas. A soma das crenças de nível estereotipadas e realistas constitui $87,5 \%$ do total de crenças sobre diferenças sexuais entre as mais velhas. A soma desses mesmos níveis para o grupo de 4 a 6 anos é de quase a metade: 47,5\%. A partir da análise desses dados poder-se-ia indicar um momento de transição na construção do conhecimento sobre diferenças sexuais em algumas das crianças. Freud assinalou que na passagem ao período de latência há resíduos da sexualidade infantil que devem ser recalcados e sublimados, e esses resíduos convivem com os diques da moral, a vergonha e o asco. Portanto, a latência é um período durante o qual muitas das defesas do ego são consolidadas e é possível que essa coexistência de forças dê lugar a um conflito em relação às diferenças sexuais e à própria identidade sexual. Nessa linha freudiana de reflexão, e a partir da idéia de evolução progressiva do conhecimento na perspectiva piagetiana, é que pode ser entendida a coexistência de crenças estereotipadas e realistas no grupo de crianças de 7 a 9 anos. A distribuição da freqüência das crenças em cada faixa etária pode ser mais bem observada na figura abaixo:

Figura 11. Distribuição percentual dos níveis de crenças sobre diferenças sexuais em cada grupo etário

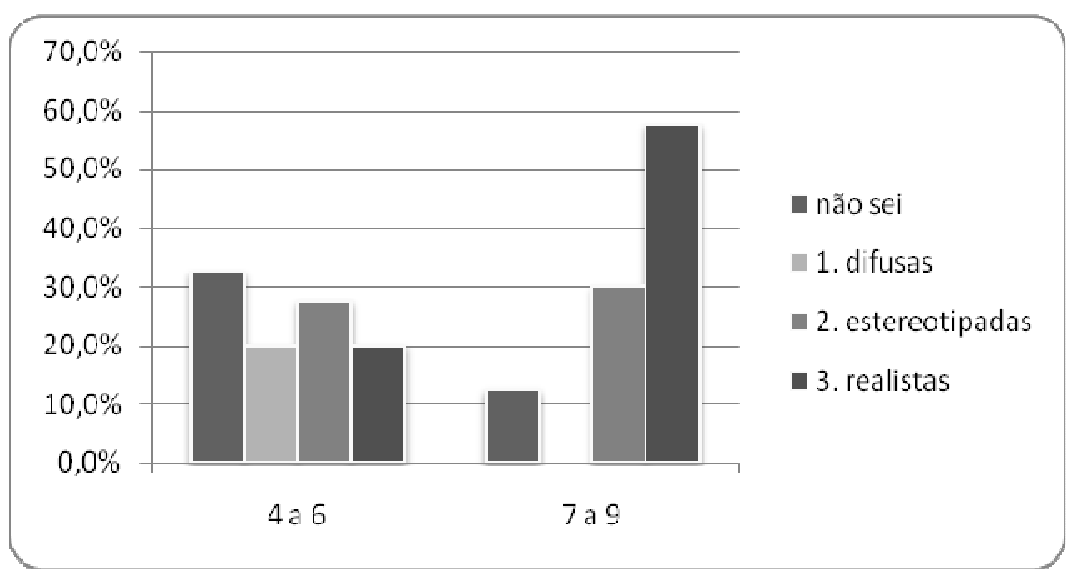

Vale fazer a seguinte observação. A distribuição dos percentuais dos níveis de crenças do grupo de crianças mais novas evidencia mais homogeneidade quando são comparados com 
a distribuição percentual das crenças do grupo de 7 a 9 anos, no qual se nota uma progressão mais nítida do nível 1 ao 3. Observa-se abaixo a distribuição entre os grupos etários para cada nível de crença.

Tabela 13. Distribuição percentual das crenças sobre diferenças sexuais em cada nível.

\begin{tabular}{cccc}
\hline Grupo etário & $\mathbf{4}$ a $\mathbf{7}$ & $\mathbf{7}$ a $\mathbf{9}$ & Total \\
\hline Crenças & & & $100 \%$ \\
\hline Não sei & $\mathbf{7 2 , 2 \%}$ & $27,8 \%$ & $100 \%$ \\
\hline Estereotipadas & $\mathbf{1 0 0 \%}$ & $0 \%$ & $100 \%$ \\
\hline Realistas & $47,8 \%$ & $52,2 \%$ & $100 \%$ \\
\hline
\end{tabular}

Figura 12. Distribuição percentual de cada nível de crença sobre diferenças sexuais.

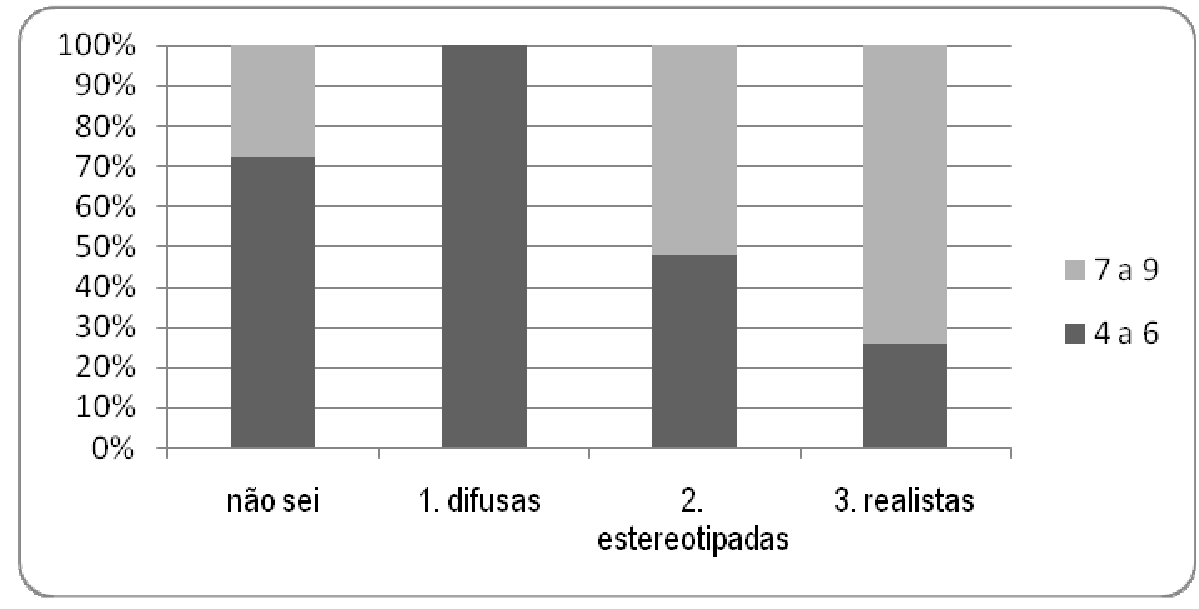

Conforme os dados, observa-se que $72 \%$ das respostas "não sei” se concentra no grupo de 4 a 6 anos. Esse alto índice de dificuldade para definir as diferenças sexuais poderia ser entendido a partir da intensidade de trabalho intelectual e pulsional provocado pela teoria falocêntrica em termos freudianos, e também a partir da falta de constância anatômica como necessidade lógica, que leva a supor muitas possibilidades de explicação simultâneas o qual dificultaria a elaboração de uma resposta à pergunta pelas diferenças sexuais. $100 \%$ das crenças difusas correspondem ao grupo das crianças mais novas, o que se corresponde com as características do pensamento pré-lógico e intuitivo. Há uma distribuição bastante equitativa entre as crenças estereotipadas, que podem ser consideradas um nível de transição, no qual convergem possíveis fatores explicativos piagetianos (progressiva conquista da conservação do gênero estudada por Kohlberg) e a vergonha como defesa características do período de latência. $74 \%$ do total de crenças realistas são afirmadas pelas crianças mais velhas, indício de 
um pensamento mais socializado e regido pela prevalência do princípio de realidade. Os dados também revelam que a construção do conhecimento sobre as diferenças sexuais a partir de elementos anatômicos genitais ou secundários aparenta ser um processo onde estão envolvidos fortes fatores cognitivos e afetivos. A respeito das crenças sobre diferenças sexuais, vale destacar uma discrepância das respostas de acordo com o sexo dos entrevistados.

Tabela 14. Distribuição da freqüiência absoluta e percentual dos níveis de crenças sobre diferenças sexuais, de acordo com o sexo das crianças

\begin{tabular}{|c|c|c|c|c|}
\hline Sexo Crenças & Não sei & Difusas & Estereotipadas & Realistas \\
\hline Masculino & $11(61 \%)$ & $4(50 \%)$ & 14 (61\%) & $8(26 \%)$ \\
\hline Feminino & 7 (39\%) & $4(50 \%)$ & $9(39 \%)$ & $23(74 \%)$ \\
\hline Total & 18 & 8 & 23 & 31 \\
\hline
\end{tabular}

Observa-se, inicialmente, que não há uma diferença substantiva em relação às crenças difusas (50\% para cada grupo). No entanto, há uma concentração das respostas do tipo "não sei” e das crenças estereotipadas entre os meninos (61\% das respostas nos dois casos). Ao contrário, do total de 31 crenças realistas que admitem caracteres anatômicos para definir diferenciação sexual, $74 \%$ foram dadas por meninas e $26 \%$ correspondem aos meninos. Essas observações mereceriam um estudo aprofundado, mas a partir dos referentes teóricos trabalhados neste estudo, pode-se inferir a intervenção da angústia de castração como um fator afetivo e cognitivo muito importante na construção dessas crenças. Tal como foi mencionado, segundo Freud, a ameaça de castração faz a menina entrar no complexo de Édipo, enquanto que o menino sai dele frente à possibilidade de ser castrado. Freud (1905, 1908, 1925) afirma que, na menina, o problema da diferença sexual se instala antes que o da origem dos bebês. $\mathrm{O}$ interesse por saber de onde vêm os bebês pode ser anterior nos meninos, mas nas meninas é sempre posterior ao problema das diferenças sexuais.

Na menina, o complexo de Édipo tem uma pré-história maior, portanto ela já sabe que não tem pênis, e quer tê-lo. Desse modo, é exigida, antes que o menino, a refletir acerca das diferenças sexuais porque, para Freud, tem que enfrentar tentativas de compensação dessa falta. Cabe assim considerar estas distinções freudianas para entender a prevalência de meninas nas crenças realistas (anatômicas). Se a angústia de castração é posterior nos meninos, porque a ameaça não foi consumada como sucede no caso das meninas, isso pode ter duas conseqüências. Por um lado, o "atraso" na admissão das diferenças sexuais em 
comparação com as meninas, que entraram no complexo de Édipo sabendo-se castradas. Por outro, os meninos poderiam apresentar uma maior tendência à negação das diferenças sexuais por critérios anatômicos (sustentando por mais tempo que as mulheres têm pênis) e manter crenças estereotipadas como uma forma de defesa, entendendo assim, que se não há seres "castrados" a ameaça sobre si mesmo seria assim amenizada.

\subsection{O pensamento da criança: entre o símbolo e a lógica}

A tendência egocêntrica/narcisista intelectual (o "Eu sei") funciona, segundo Piaget, como a única prova possível da qual a lógica infantil se serve durante muito tempo, porque a criança dá a sua própria resposta com convicção e não espera as de outrem. De modo geral, no plano do pensamento verbal as idéias se tornam crenças. Sem inserir seu pensamento íntimo e sua afetividade no esquema das trocas interindividuais, o isolamento impede a estruturação lógica de seu pensamento (Piaget, 1924/1947). A partir do referencial teórico dos trabalhos piagetianos nos quais dialoga com a psicanálise, são apresentadas as principais tendências do pensamento simbólico e dos aspectos vinculares da criança que provocaram o postulado de esquemas afetivos, com desenvolvimento paralelo e interdependente aos cognitivos. Para indagar as fontes de informação a partir das quais as crianças conheciam e explicavam o nascimento, logo após afirmar que o bebê sai da barriga, perguntou-se: "Como é que você sabe isso?" (Q2). As respostas evidenciam essas tendências egocêntricas mencionadas.

As crenças sobre as fontes de informação vão da auto-referência à consideração de outros informantes. A auto-referência contempla não só qualidades pessoais, mas também lembranças da própria vida intra-uterina ou o nascimento. $\mathrm{O}$ informante mais mencionado pelas crianças é a mãe. A escola aparece nas respostas, mas é amplamente superada pela referência a outros meios.

Quadro 5. Níveis de crenças sobre fontes de informação

\begin{tabular}{|c|l|}
\hline N 1 & $\begin{array}{l}\text { AUTO-REFERENCIAIS. Respostas egocêntrico-narcisistas. A criança } \\
\text { considera que sabe porque é esperta, inteligente, nasceu sabendo, sempre } \\
\text { soube, ou lembra de quando estava na barriga. }\end{array}$ \\
\hline N 2 & $\begin{array}{l}\text { REFERENTES À FAMÍLIA. Aludem à mãe, pai, avós ou tias. Pode } \\
\text { justificar seu conhecimento por eventos familiares, como sua mãe ou tia } \\
\text { grávida. }\end{array}$ \\
\hline
\end{tabular}


N 3 OUTROS INFORMANTES. Através do âmbito escolar ou de outras instituições. Menção à televisão (novelas, repórter), livros, ultra-som, fotos, vídeos ou internet.

Quando se perguntou às crianças como sabiam que o bebê sai da barriga (Q2), 14 do grupo das mais novas responderam nessa linha auto-referencial narcisista/egocêntrica. Incluíram qualidades pessoais como inteligência e lembranças pessoais. Vejamos a seguir alguns exemplos de crenças auto-referenciais:

E1 (F 4,8) É porque eu sou esperta

E2 (F 4,3) É porque eu nasci da barriga da minha mãe.

E5 (F 4,8) Como sei? É porque eu nasci sabendo (...). Eu vi que o médico estava abrindo a minha barriga e vi o negócio na mão dele, só que eu não me lembro de nada.

E27 (F 6,6) Porque eu me lembro quando eu nasci.

E18 (M 6) Como sei? É que eu sou inteligente, você já sabe disso.

E28 (F 6,1) Bem, eu aprendi sozinha. Quando eu crescer, e ficar adulta, aí eu vou ter um bebê.

E12 (F, 5) Eu nasci da minha mãe da barriga, aí eu lembrei disso. A mãe fica com a barriga grande e eu estava bem na barriga da minha mãe, a minha cabeça estava aqui (assinala a sua barriga). (...) Eu tive que aprender tudo isso. Eu sei.

E35 (F 5,2) É que eu já nasci. Você lembra isso? Eu nasci no Brasil. O médico... minha mãe deitou e cortou ao meio e aí saí eu. Você lembra quando estava dentro da barriga? Sim. Tinha cheio de sangue, e eu nasci cheia de sangue. O que fazia dentro da barriga? Eu ficava chorando. Eu era bebê, não sabia falar.

Como entender as respostas das crianças acerca das suas lembranças sobre sua estadia intra-uterina e o próprio nascimento? Piaget assinala que a noção de memória no plano da representação não consiste em uma reserva exata do passado no inconsciente e não funciona como um depósito de recordações-imagens iluminadas pela consciência. Da mesma forma que a hipótese de reconstrução (dos esquemas afetivos e do Superego), a proposta piagetiana é de uma memória recordação-reconstrução. Sendo assim, existem fatores diversos que influenciam uma organização ativa das recordações como os julgamentos e as conexões lógicas. Se o recalcamento é o recurso psicanalítico para explicar a ausência de lembranças dos primeiros anos, a concepção da memória como reconstrução ofereceria outra solução: nos primeiros anos não há ainda memória de evocação para organizá-las. Dito de outra forma:

A memória de recognição, com efeito, não implica de modo algum, a capacidade de evocar lembranças, porque esta supõe a imagem mental, a linguagem interior e os primórdios da inteligência conceitual. A memória da criança de dois a três anos é ainda uma mistura de relatos fabulados e de reconstituições exatas, mas caóticas e a memória organizada só se desenvolve com o progresso da inteligência integral (Piaget, 1945/1975, p. 241). 
O próprio Piaget conta com uma antiga lembrança, varias vezes narrada nas suas obras, sobre uma suposta tentativa de rapto quando ele tinha dois anos. Foi a sua babá que o salvou do arrebatamento do ladrão enquanto o levava a passear em um carrinho de bebê. Ele lembra detalhes como a cara machucada da mulher, a correia de couro que o sujeitava, um guarda civil com capinha e bastão branco que se aproximou até o lugar dos fatos, e a localização da cena perto da estação do metrô. Mas essa cena nunca ocorreu de verdade. A narrativa desses fatos inventados pela babá, nos quais seus pais também acreditavam, foi escutada quando ele era criança e projetada no passado na forma de lembrança visual. Assim, para Piaget são freqüentes as lembranças verdadeiras e "falsas" que participam na construção das crenças.

No caso das crianças mais velhas, nenhuma das respostas coletadas se define em termos desse egocentrismo integral, mas sempre aludem a terceiros ou a suportes midiáticos para explicar a fonte das informações recebidas:

E50 (M 8,7) A professora explicou um pouco.

E52 (F 8,7) A minha mãe e minha irmã já me falou.

E65 (F 7,6) Porque tem um vídeo que é em espanhol que fica no youtube. Você assistiu com sua mãe? Sim. É que a minha mãe é bióloga e ela me conta.

E43 (M 8,1) Porque eu já vi na televisão.

E63 (M 7,5) Eu lembro quando meu irmão nasceu.

E54 (M 9) A minha mãe uma vez ela já me explicou.

\section{Análise quantitativa das crenças sobre fontes de informação}

Para a análise quantitativa, as respostas sobre fontes de informação foram organizadas nas seguintes tabelas e figuras.

Tabela 15. Distribuição de freqüência absoluta e percentual das crenças sobre fontes de informação por

\begin{tabular}{ccccc}
\hline & \multicolumn{3}{c}{ grupo etário } \\
Grupo etário & Não sei & $\begin{array}{c}\text { Auto- } \\
\text { referenciais }\end{array}$ & Família & $\begin{array}{c}\text { Outros } \\
\text { informantes }^{*}\end{array}$ \\
\hline 4 a 6 & $\begin{array}{c}8 \\
(20 \%)\end{array}$ & $\begin{array}{c}14 \\
(35 \%)\end{array}$ & $\begin{array}{c}13 \\
(32,5 \%)\end{array}$ & $\begin{array}{c}5 \\
(12,5 \%)\end{array}$ \\
\hline 7 a 9 & $\begin{array}{c}11 \\
(27,5 \%)\end{array}$ & 0 & 22 & 7 \\
Total & 19 & 14 & 35 & $(17,5 \%)$ \\
\hline
\end{tabular}

*Inclui escola, meios de comunicação etc. 
Figura 13. Distribuição comparativa da freqüência percentual de crenças sobre diferenças sexuais do mesmo nível para cada grupo etário

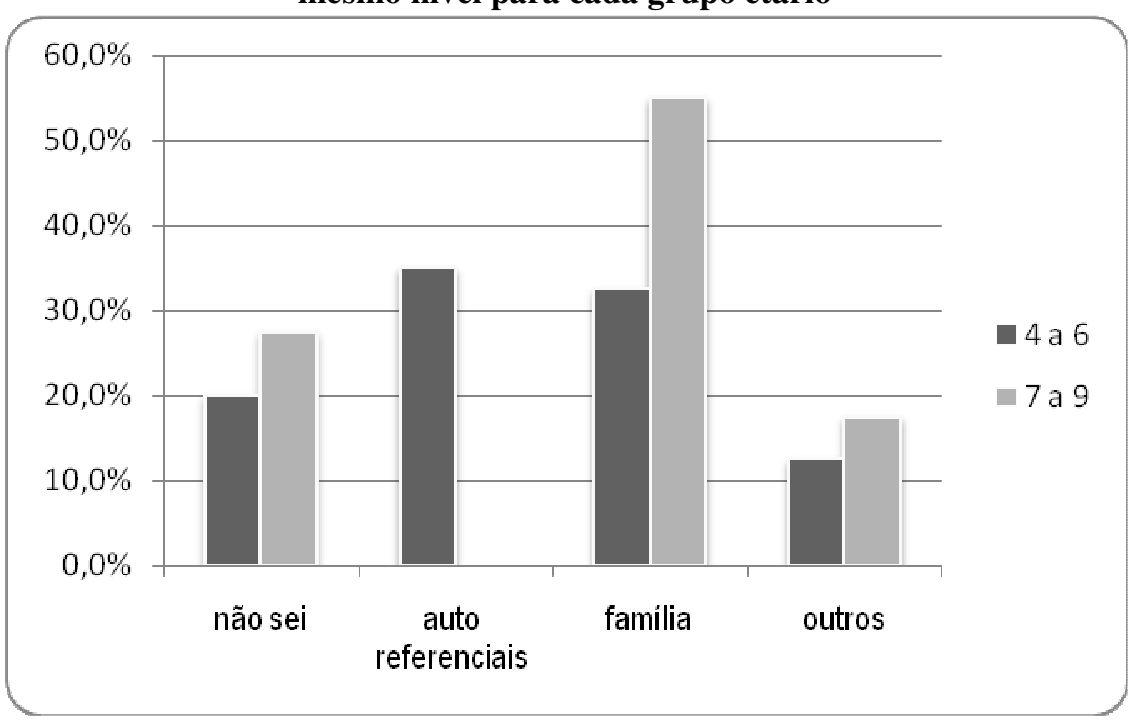

Inicialmente, cabe formular uma hipótese sobre o alto índice de crianças que responderam "não sei” a esta questão, embora a porcentagem seja levemente menor entre as crianças mais novas $(20 \%)$ do que entre as mais velhas $(27,5 \%)$. Esta alta porcentagem poderia ser um indicador da dificuldade da criança para diferenciar o que provêm dela mesma e o que provém do exterior, na linha já comentada da diferenciação progressiva do eu e do não-eu. Por outro lado, a pergunta como você sabe? é complexa por seu caráter epistemológico que implica um elevado nível de reflexão. Portanto, crianças que estão atravessando um período de transição para um pensamento mais socializado preferiram responder "não sei” antes de manifestar crenças auto-referenciais egocêntricas.

Em seguida, verifica-se que $35 \%$ das crianças mais novas considera que seus conhecimentos provêm de sua própria inteligência ou lembrança (crenças auto-referenciais), enquanto nenhuma das crianças de 7 a 9 anos justifica sua resposta a partir de si mesma. Cabe ressaltar também que as crianças mais velhas não apelaram em nenhum caso a lembranças pessoais intra-uterinas ou de nascimento, e até ficam surpresas quando a pesquisadora perguntava a respeito dessa questão: E67 (M 8,11) Você lembra quando estava dentro da barriga? "Não! (ri) Nem de quando era bebê. Eu só vejo fotos ou a minha mãe me conta". Esta tendência de diminuir, conforme a idade, as referências ao próprio eu para explicar fenômenos biológicos gerais corresponde ao conceito piagetiano de descentração e a progressiva prevalência dos processos secundários.

Observa-se ainda, uma maior porcentagem de respostas com referenciais externos entre as crianças mais velhas em relação às mais novas: $55 \%$ contra $32,5 \%$ de referências familiares e 17,5\% contra 12,5\% de outras fontes de informação. As respostas em que as 
crianças de 4 a 6 anos justificam seu conhecimento a partir de si mesmas e de sua família totalizam $67,5 \%$. respostas. Das cinco crianças novas que apelam a informantes extra-família, uma menciona a escola, três internet ou televisão, e uma a professora de balé. Reunindo os percentuais dos níveis 3 e 4 encontra-se que mais de $70 \%$ das crianças de 7 a 9 anos afirma que seus conhecimentos provêm do entorno familiar ou extra-familiar.

Os dados mostram que a família é o informante mais mencionado, entre as referências externas. Contudo, é preciso destacar que das 35 crianças (do total de 80) que mencionam fontes de informação familiares, 29 especificam que foi a mãe que contou, enquanto nenhuma menciona o pai como único informante. A família constitui um informante não só verbal, mas em alguns casos a criança justifica suas crenças a partir das experiências de nascimentos de primos, irmãos ou sobrinhos. Vale ressaltar, no entanto, que tanto o referente familiar como os "outros" (a escola e a mídia) possuem uma freqüência relativa maior entre as crianças mais velhas, na medida em que estas não argumentam a partir de elementos auto-referenciais e manifestam assim, um pensamento mais socializado. A figura a seguir mostra de maneira mais clara esta tendência.

Figura 14. Distribuição percentual das crenças sobre fontes de informação em cada grupo etário

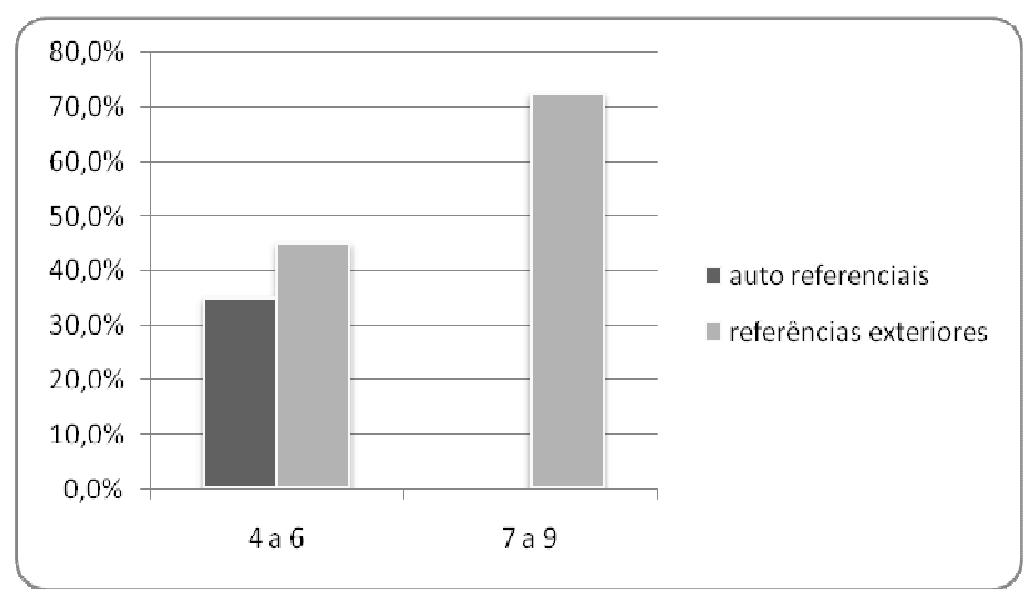

Nesta etapa da análise, foram consideradas somente duas categorias: "auto-referenciais" e "referências exteriores" (somando família e outros). Vale lembrar que: 1) a maioria dessas referências vem da família, seguindo da escola e da mídia; 2) algumas respostas das crianças mais velhas contemplam a referência a mais de um elemento.

Vale mencionar que, entre os entrevistados mais velhos que apelam a informantes escolares ou midiáticos, o fazem não só para responder a Q2 (“como é que você sabe?”), mas também para aprofundar suas argumentações ao longo da entrevista. É o caso de E41 e E77, que nomeiam distintas fontes ao longo da entrevista: 
E41 (F 8,7) A professora falou que a gente ficou 9 meses na barriga (...) Eu já vi filhotes de cachorro nascendo. (...) Isso aí eu escutei de um programa.

E77 (M 8) A professora da escola disse (...) Já vi em novela (...) Eu vi no repórter.

A seguir, apresenta-se a distribuição do total de cada nível de crença sobre fontes de informação segundo o grupo etário:

Tabela 16. Distribuição percentual das crenças sobre fontes de informação em cada nível

\begin{tabular}{cccc}
\hline & Grupo etário & $\mathbf{7}$ & Total \\
Crenças & $\mathbf{7} \mathbf{6}$ & & \\
\hline Não sei & $42,1 \%$ & $57,9 \%$ & $100 \%$ \\
\hline Auto-referenciais & $\mathbf{1 0 0 \%}$ & $0 \%$ & $100 \%$ \\
\hline Família & $37,1 \%$ & $\mathbf{6 2 , 9 \%}$ & $100 \%$ \\
\hline Outros informantes & $41,7 \%$ & $58,3 \%$ & $100 \%$ \\
\hline
\end{tabular}

Figura 15. Distribuição percentual das crenças sobre fontes de informação em cada nível

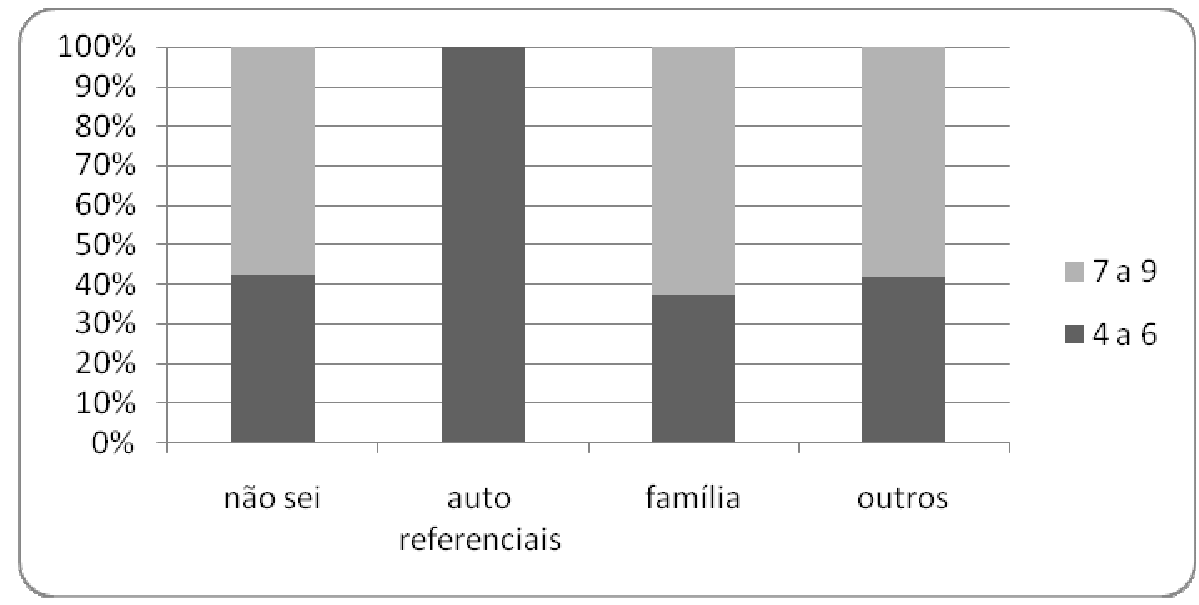

Verifica-se que as respostas auto-referenciais se concentram nas crianças mais novas (100\%), enquanto que nenhuma delas corresponde ao grupo etário de 7 a 9 anos. Do total de respostas que contemplam informantes familiares e extra-familiares, em ambos os casos observou-se uma maior prevalência nas crianças mais velhas $(62,9 \%$ e $58,3 \%$ respectivamente).

Além do egocentrismo evidenciado nas explicações sobre fontes de informação, este também prevalece nas explicações gerais das crianças de 4 a 6 anos. Como já foi comentado, o narcisismo/egocentrismo não é só intelectual, mas também afetivo. Os vínculos próximos da criança, especialmente seus pais estão sempre presentes nas respostas. E15 (F 6,6) evidencia o 
esforço para deixar de apelar à própria mãe para responder a pergunta sobre a alimentação do bebê:

(O bebê) come? Come. Toda vez que a minha mãe (pausa)... Olha, eu acho que o que a mãe quiser é o que ele come... Por causa de que quando a minha mãe... eu acho que quando a mãe come alguma coisa, aí come ele.

Para responder à pergunta introdutória da dinâmica da entrevista (Q0) acerca da possibilidade de que os animais limpem as casas, E73 (M 7) apela à experiência particular com seu papagaio que resulta num argumento suficiente:

Você acha que os animais podem limpar a casa? Acho que não porque meu papagaio ele come e aí deixa a maior sujeira.

A partir dos dados coletados, pode-se afirmar que o egocentrismo permeia a maioria das respostas das crianças mais novas. Nas suas crenças aparecem suas vivências presentes e passadas, anedotas e características de seus pais, suas lembranças intra-uterinas e a sua história familiar em geral. O sistema explicativo das crianças sobre a origem dos bebês prevalece estruturado em torno de uma única referência: elas mesmas.

Os dados das crianças mais novas evidenciam uma concentração de respostas autoreferenciais nos quais a própria criança aparece em cena na explicação do fenômeno. Algumas dessas respostas aludem às lembranças da sua própria vida intra-uterina ou nascimento, o que verifica a noção de "lembranças falsas" de Piaget e de memória e fantasias em Freud. Alguns exemplos são:

E8 (F 4,7) Ele não come nada, ele só... do coração da mãe que está na barriga dela. Eu lembro que quando eu era bebê, eu pegava do coração da minha mãe. E aí cortaram a barriga de minha mãe e aí depois eu saí.

E13 (M 5,1) Dentro da barriga o bebê tem dentes? Quando eles crescem, eles têm dentes, igual que eu que ganhei dentes agora. Se eu cresci e antes não tinha dentes, eu não conseguia comer nada.

E32 (F 6,1) Como faz o bebê para comer dentro da barriga? Eu como e daí vai baixando na barriga. E quando eu crescer vou ter um bebê e não vou poder comer. Por que não vai poder comer? Porque eu acho que o bebê também come. Como come o bebêe? Não sei, com a faca.

E34 (M 6) Como faz o bebê para comer dentro da barriga? Eu abria a boca, a minha mãe ia dando. Comia comida e eu comia junto. Aí minha mãe dava papinha para mim, agora não como mais papinha. Dentro da barriga eu ficava dormindo. Quando era dia eu acordava.

A experiência de hostilidade fraterna, conflito estrutural analisado por Freud (cf. item 3.5 Teorias sexuais infantis), foi explicitada espontaneamente na entrevista com E73 (M 7), 
que tem três irmãos mais velhos. Para iniciar a conversa, perguntamos se ele tinha irmãos. Mostrando interesse pelo tema respondeu enfaticamente:

Eu tenho três irmãos, então, o que acontece? Os meus irmãos, todo dia eles chegam lá e me batem, só por um motivo: porque eu sou pequeno.

Nessa declaração também pode ser assinalada um "fragmento de verdade", já que a justificativa de E73 a respeito de porque recebe golpes dos irmãos velhos converge com a explicação freudiana: a hostilidade é simplesmente o resultado de E73 ser o mais novo, e ter chegado à família modificando dinâmicas e atenções recebidas pelos maiores.

Outras características do pensamento simbólico e dos processos primários também foram evidenciadas na análise dos dados obtidos nas entrevistas. Os indicadores empíricos analisados, mostraram uma tendência ao pensamento simbólico e pré-lógico nas crianças do grupo etário de 4 a 6 anos. A condensação ou sincretismo do pensamento é o fenômeno pelo qual diferentes imagens, personagens ou ações se misturam e se apresentam de forma justaposta ou seqüencialmente desordenada. E10 (F 5) junta uma experiência com filhotes ao desejo da mãe de ter bebês. Além disso, sua fala egocêntrica toma como pressuposto que o interlocutor consegue entender o fio de seu raciocínio embora esteja fazendo uma fusão de conteúdos entre filhotes e bebês:

Onde (os filhotes) estavam antes de nascer? Estavam na barriga, eu acho... Como eles chegam à barriga? É só pedir ao papai do céu e aí o papai do céu dá. Quando a minha mãe... quando ela... eu não lembro bem como é que foi... Ela pediu para Deus dar dois filhotes para ela... Cachorrinhos ou bebês? Bebês. É que, é assim, eu estou falando de filhotes e de gente, entendeu?

Ao mesmo tempo, para ter um filho a moça tem que se casar grávida, porque assim foi como ocorreu com a sua mãe:

E10 (F 5) O que é preciso fazer para ter um bebê? (...) primeiro tem que pedir para o papai do Céu, a moça tem que casar com a barriga grande, aí tem que ir no médico. Porque a minha mãe se casou com a barriga grande, eu tinha uma fita do casamento dela

Em vários casos se mistura a resposta geral à pergunta com experiências pessoais, sendo que tudo remete ao próprio entrevistado:

E12 (F 5) Como sai o bebê da barriga? O médico corta, esqueceu? Como corta? Corta com uma faca e aí eu nasço e eu fico em casa com meu pai, e a minha mãe fica lá no médico costurando a barriga. 
A justaposição de elementos evidencia a dificuldade da criança para atingir a coordenação das informações e anular as contradições organizando seu pensamento em um sistema coerente. A criança condensa informações diversas na mesma explicação:

E9 (F 5) Dentro da barriga o bebê cresce? Cresce; ele fica lá no céu, depois quando ele fica no céu ele come uma semente e vai crescendo até chegar na barriga, depois, ele fica deste tamanho.

E30 (M 6,2) Quando a mãe arranja um namorado, casa, depois passa um pouquinho mais de tempo, a semente racha no meio. Aí quando a mãe faz cocô a semente cai na privada. Depois o bebê fica lá dentro, é bem pequeno aí vai crescendo, crescendo.

Observa-se nas citações acima, a justaposição do elemento semente com a preexistência no céu em E9, e a teoria da semente condensando características botânicas (a semente racha no meio) em E30.

No período pré-operatório a criança remete ao plano do provável confundindo ficção com realidade. Só posteriormente, no período operatório, manejará esse plano a partir da necessidade lógica. E17 (M 6,3), cuja mãe estava grávida, contou que havia assistido ao filme Dumbo que inicia com a cena de uma cegonha levando bebês para os animais do circo. E17 justapõe as imagens de Dumbo com o fato de que a sua mãe tem um bebê na barriga. Assim mistura realidade com ficção condensando essas imagens na mesma resposta egocêntrica:

Como faz o bebê para sair da barriga? Leva a nossa mãe para o hospital, e aí os médicos tiram ele da barriga. Como tiram? A "garçonha" [querendo dizer cegonha] ela leva até a mãe. $O$ que é a garçonha? É o animal que leva o bebê para a mãe. O outro dia eu assisti Dumbo e todos os bichos vinham da cegonha. A cegonha pega no bico e leva até a mãe. Ele (o bebê) fica dentro da barriga até minha mãe ter dor e a barriga crescer. Daí eu levo ela no hospital e a cegonha tira o bebê.

Tal como fora mencionado a partir das contribuições de Mijolla-Mellor (cf. item 3.6), com o problema do nascimento a criança experimenta um "desequilíbrio do narcisismo" (a partir da idéia de que não sempre existiu nem vai existir), começa a se posicionar no contexto temporal do ciclo da vida e se projeta no futuro. Em relação a isso, a partir da experiência de gravidez da sua mãe, E17 (M 6,3) mostra indícios de interesse na questão de se situar no tempo e nas gerações pensando na morte e no futuro:

Para ter um bebê tem que passar muitos anos... Até eu crescer, a Alice (futura irmã) vai ficar com três anos, quando ela estiver com três anos eu vou estar com dez... (pensa)... Porque vai demorar para eu arrumar filhos, daí no final do ano vai nascer e eu vou fazer aniversário (...) Quando eu crescer e tiver minha filha e meu filho, e eu casar, minha mãe vai estar velha, não vai? E quando meu vô, ele estava velho, meu vô da Bahia, estava velho, e morreu. Ele não morreu, foi para o Céu. 
Além do egocentrismo e da condensação, o pensamento pré-lógico também admite as seguintes formas de organização mental evidente em respostas:

- Tautológicas: E24 (F 6,2) Por que as pessoas se casam? Se casam para ter filhos. E o que fazem para ter filhos? Eles casam.

- Animistas: E53 (F 8,8) A mãe mastiga e ficam aqueles pedacinhos bem pequenos, aí o bebê vai comendo um pouquinho. E o bebê como pega a comida? A comida cai e ele fica com a boquinha aberta. Quando fica com fome, não é você que fica com fome, é o bebê.

- Focadas nas aparências e estados: E7 (M 4,8) Aí, quando minha mãe ficou magra, ficou pequena e depois ficou grávida e ficou gorda.

- Mágicas: E8 (F 4,7) O anjinho faz aparecer o bebê. Só que o anjinho faz aparecer com a mão, sem varinha. Como você sabe isso? Como sei? É porque eu nasci sabendo.

A respeito da admissão da contradição e da negação, alguns entrevistados negam com firmeza o que acabam de afirmar minutos antes. E4 (M 4,8) afirma que tem que cortar a barriga para o bebê sair, mas no final da entrevista o nega:

De onde você acha que vem os bebês? Bebês vêm da barriga. De quem? Das mamães. Como saem? Tem que chamar um médico e ali ele corta com uma tesoura. [Algumas perguntas mais adiante] E aí (quando o bebê sai da barriga) passa isso que você falou que o médico tem que cortar com uma tesoura? O quê?... Lembra que você falou do médico que corta a barriga? Não falei não.

E10 (F 5) na mesma resposta, afirma e nega o crescimento do bebê:

O bebê cresce? Não. Que tamanho tem dentro da barriga? Quando o bebê vai nascer na barriga ele é deste tamanhinho assim, daí quando passam dias, ele acaba ficando mais um pouco grandinho. Por que cresce? Porque ele está dentro da barriga e demora muitos anos e quando ele come porque o neném fica dentro da barriga, então come a comida que a mamãe come e dentro da barriga ele vai crescendo.

E1 (F 4,8) afirma a preexistência do bebê no céu e logo depois a nega.

Para ter um bebê a gente precisa pedir para o papa do Céu (pensa) ai vai, vai, até que chega o bebê do céu. Onde? Eu sei que ele vai na barriga só que para a mamãe tirar ele precisa .... precisa... Para ele nascer precisa ir num hospital. (...) onde estava antes de estar na barriga? Em nenhum lugar.

A teoria piagetiana sustenta que "em todos os níveis a elaboração da causalidade interage com a das operações, o que equivale a dizer que esses dois desenvolvimentos se 
favorecem mutuamente" (Piaget, 1971/1973, p. 23). O fato das crianças mais novas não terem atingido o pensamento operatório as conduz a explicações pré-causais e contraditórias. Nas palavras de Piaget, a criança permanece insensível à contradição e "oscilará incessantemente no decorrer de seus raciocínios, entre a concepção implícita que ela possui e a definição parcial que ela dá" (Piaget 1924/1947, p. 161). Especialmente se o fenômeno que tem que explicar se deve à super-determinação de fatores, que ela não pode nem adicionar nem multiplicar logicamente, resulta difícil que possa considerá-los simultaneamente na consciência, e isso constituirá uma fonte de contradições mais considerável ainda. Os tipos estruturais de contradição são: por amnésia ou por condensação.

A contradição por amnésia consiste em que, em vez de escolher entre duas razões, a criança afirma as duas, cada uma por vez. Após a mudança de opinião, ela esquece sua crença anterior (esse tipo de contradição é também comum nos adultos). Na criança há heterogeneidade de realidades (por exemplo, do jogo, do observado, do ouvido) e elas são incoerentes e independentes entre si. Por isso suas opiniões variam e há nesta "instabilidade notável da crença", um fator muito importante de contradição por amnésia (ibid, p. 161-162). A contradição por condensação é específica da criança porque ela aglomera fatores heterogêneos sem somá-los nem multiplicá-los logicamente. Para Piaget essa contradição é resultado de uma "incapacidade de controle e de eliminação" que traz as seguintes conseqüências:

A criança se encontrará incessantemente em presença de alternativas, e que, não conseguindo manipular a multiplicação lógica, ela se submeterá, simplesmente, aos dois termos da alternativa ao mesmo tempo, e, por conseguinte, à contradição. A condensação é, portanto o resultado da super-determinação (Piaget 1924/1947, p. 165).

Essa noção de "conglomerado heterogêneo e contraditório" se contrapõe à idéia de conceito como sistema. Na perspectiva piagetiana, o significado psicológico das contradições infantis tem também relação com sua vida afetiva porque os sentimentos comportam ambivalência. A não contradição lógica é um estado de equilíbrio psicológico dinâmico. Porém, na criança pequena, não há ainda um equilíbrio entre assimilação e acomodação, prevalecendo a primeira como assimilação deformante. Um exemplo disso é o pré-conceito e o pensamento artificialista que implicam um grau menor de acomodação por parte do sujeito à realidade. 
Em resumo, pode se afirmar que os dados do grupo etário de 4 a 6 anos acima apresentados mostram prevalência de características próprias a um pensamento pré-lógico e egocêntrico quando são comparados com os dados das crianças de 7 a 9 anos. A sua análise mostra que as declarações das crianças dessa idade admitem contradições, contém elementos mágicos, são focadas nas aparências e nos estados desconsiderando assim os processos. Em linhas gerais as argumentações sempre remetem à própria criança (o recorrente "eu") para explicar o fenômeno da origem dos bebês. Este traço de narcisismo se manifesta na onipotência dos pensamentos, e no primado do princípio de prazer, em detrimento do princípio de realidade, que será a tendência dominante conquistada à par do pensamento operatório concreto. A adaptação à realidade vai ser qualitativamente diversa de acordo com os níveis de desenvolvimento dos processos secundários, do Ego e do período de latência em geral. Estas reflexões serão aprofundadas no próximo capítulo. 


\section{DISCUSSÃO}

Tanto para Piaget como para Freud, o Eu não é dado desde o início, mas se desenvolve, portanto, manifesta diferentes níveis de expansão, subjetividade e consciência de si. Essa progressiva expansão e conquista da objetividade foi corroborada na análise das crenças aqui pesquisadas. Para as duas concepções teóricas, o Eu se constrói, respectivamente, a partir de processos de descentração e mitigação do narcisismo infantil. Egocentrismo e narcisismo são conceitos relevantes para entender as suas concepções de infância e para ambos essas características serão atenuadas em favor da adaptação do Eu à realidade. Atenuadas e não extinguidas porque ambos os autores convergem em uma visão integrativa do desenvolvimento, portanto, egocentrismo e narcisismo podem se manifestar nos adultos, ainda que em expressões qualitativamente diversas das condutas das crianças. As características deste desenvolvimento do Eu das crianças de 4 a 9 anos permitiram entender e analisar as diferenças entre as crenças egocêntricas das mais novas, e as respostas mais descentradas e socializadas das mais velhas.

De modo geral, é possível observar diferenças aparentemente significativas entre as respostas das crianças em função dos grupos etários. Nos distintos eixos temáticos a maioria ou totalidade de respostas dos últimos níveis (as mais descentradas e de melhor qualidade) aparecem nas crianças velhas. Da mesma forma, os primeiros níveis das crenças (respostas mais egocêntricas e pré-lógicas) prevalecem nas crianças mais novas. Consequientemente, os dados estão de acordo com a expectativa teórica piagetiana da progressão genética do conhecimento por estágios e com as apreciações freudianas gerais acerca dos aspectos psicodinâmicos do pensamento e das fases do desenvolvimento psicossexual. A distinção piagetiana entre gênese (como se forma e evolui a concepção) e estrutura (coerência interna das explicações) também pôde ser estudada à luz dos resultados aqui levantados. A primeira foi vislumbrada na disposição diacrônica dos dados segundo os níveis das crenças, e a segunda foi considerada no corte sincrônico realizado a partir da análise das crenças no contexto das características intrínsecas a cada etapa do desenvolvimento e seus respectivos processos de pensamento.

Novamente aqui é importante lembrar duas questões. Em primeiro lugar, indicar que os níveis das crenças só foram elaborados após várias leituras e releituras das entrevistas para sistematizar suas regularidades, ou seja, que não foram considerados a priori no momento de realizar as entrevistas para logo tentar "encaixar" neles as respostas. Em segundo lugar, cabe 
destacar que para ambas as perspectivas teóricas as idades são sempre aproximadas, sendo invariável a ordem de sucessão dos estágios.

Os resultados obtidos mostram que o diálogo entre alguns conceitos da psicogênese piagetiana e da psicanálise freudiana permitem aprofundar a compreensão das tendências na construção das crenças acerca da origem dos bebês. Primeiro, por ambas ter teorizado acerca do desenvolvimento da criança, e segundo, por ter abordado a construção desse conhecimento a partir das possibilidades e limites que esse desenvolvimento proporciona. Em torno da origem dos bebês subjaz, mais ou menos explicitamente: o narcisismo infantil, o vínculo da criança com seus pais e irmãos, a própria imagem de si e de seu corpo em um contexto de relações físicas, lógicas, espaciais, temporais e psíquicas, e as diferenças sexuais, como primeiro critério no início da categorização-organização do mundo.

A comparação das respostas das entrevistas a partir dos grupos etários mostra um desenvolvimento que, em linhas gerais, evidencia uma transição: do concreto (dados perceptivos) ao abstrato, do subjetivo ao objetivo, do egocêntrico ao descentrado e coordenado, e do difuso ao mais preciso. Essa passagem é progressiva e mostra tendências, posto que em cada entrevista coexistem, em maior ou menor medida, traços intermediários entre esses pólos. A respeito disso, Piaget afirma que "a passagem da ação ao pensamento ou do esquema sensório-motor ao conceito não se realiza sob a forma de uma revolução brusca, mas pelo contrário, de uma diferenciação lenta e laboriosa, que se relaciona às transformações da assimilação" (Piaget, 1970a/1983, p. 13).

O autor define que essa transformação do pensamento não se dá por começos absolutos, porque o novo sempre procede ou de diferenciações progressivas, ou de coordenações graduais, ou de ambas. Para Piaget, "as diferenças de natureza que separam as condutas de um estágio das que precedem, não se as pode então conceber senão como uma passagem limítrofe" (ibid, p. 18, o negrito é nosso).

Posto que esta pesquisa focaliza um período de transição, seria errôneo afirmar, de modo taxativo, que as crianças mais novas manifestam crenças totalmente egocêntricas, e as mais velhas crenças puramente realistas e lógicas. Este é um aspecto contemplado tanto pela proposta teórica piagetiana como pela freudiana, ao entender que o desenvolvimento é progressivo e que cada período pode apresentar coexistência de elementos do anterior. $\mathrm{Na}$ perspectiva piagetiana, “cada etapa da sucessão, desde as primeiras, se orienta na direção das estruturas operatórias ou lógicas" (Piaget, 1964, p. 153). A diferença entre as estruturas prélógicas e lógicas está no grau de reversibilidade atingido pelas estruturas: "não é uma lei de tudo ou nada, mas de infinitos graus a partir das regulações mais elementares" (ibidem). Em 
relação ao equilíbrio, o pensamento pré-lógico se corresponde com estruturas pouco equilibradas ou instáveis e o lógico com formas equilibradas superiores.

A seguir, apresenta-se um quadro representativo das tendências dessa transição a partir da síntese dos principais resultados da pesquisa. O quadro contempla os "pólos" das crenças (comparação entre os níveis 1 e 3, ou 1 e 4, dependendo do eixo temático) e os percentuais correspondentes a cada grupo etário. Na coluna interpretação apresenta-se um breve esboço das principais características cognitivas e afetivas já desenvolvidas nos capítulos anteriores e que permitiriam explicar a prevalência de uma ou outra crença.

Quadro 6. Síntese das principais tendências observadas a partir dos resultados

\begin{tabular}{|c|c|c|c|c|}
\hline \multirow[t]{2}{*}{ Eixos temáticos } & \multirow[t]{2}{*}{ Níveis das crenças } & \multicolumn{2}{|c|}{$\begin{array}{l}\text { Freqüência } \\
\text { percentual por } \\
\text { grupo etário }\end{array}$} & \multirow{2}{*}{$\begin{array}{c}\text { Interpretação } \\
\text { (indícios de mecanismos } \\
\text { representativos) }\end{array}$} \\
\hline & & $\begin{array}{l}4 \text { a } 6 \\
\text { anos }\end{array}$ & $\begin{array}{l}7 \text { a } 9 \\
\text { anos }\end{array}$ & \\
\hline \multirow{2}{*}{ Fecundação } & Mágicas & $55 \%$ & $15 \%$ & $\begin{array}{c}\text { Pré-causalidade, artificialismo e } \\
\text { preexistência }\end{array}$ \\
\hline & Realistas & $0 \%$ & $55 \%$ & O pensamento lógico exclui a magia \\
\hline \multirow{2}{*}{ Alimentação } & egocêntrico-animistas & $42,5 \%$ & $22,5 \%$ & $\begin{array}{c}\text { Extensão de esquemas de ação próprios à } \\
\text { vida intra-uterina }\end{array}$ \\
\hline & artificialista-técnicas & $5 \%$ & $52,5 \%$ & Artificialismo técnico \\
\hline \multirow{2}{*}{ Nascimento } & Parciais & $72,5 \%$ & $37,5 \%$ & A vagina como obstáculo cognitivo \\
\hline & realistas & $7,5 \%$ & $45 \%$ & $\begin{array}{l}\text { Pensamento socializado, processos } \\
\text { secundários. }\end{array}$ \\
\hline \multirow{2}{*}{$\begin{array}{l}\text { Diferenças } \\
\text { sexuais }\end{array}$} & não sei + crenças difusas & $52,5 \%$ & $12,5 \%$ & $\begin{array}{c}\text { Teoria falocêntrica + intuição pré- } \\
\text { operatória }\end{array}$ \\
\hline & realistas & $20 \%$ & $57,5 \%$ & $\begin{array}{l}\text { Abandono da teoria falocêntrica e } \\
\text { conservação da sustância. }\end{array}$ \\
\hline \multirow{2}{*}{ Informantes } & auto-referenciais & $35 \%$ & $0 \%$ & Egocentrismo cognitivo e afetivo \\
\hline & externos & $45 \%$ & $72,5 \%$ & Descentração, diferenciação eu-não eu. \\
\hline
\end{tabular}

A respeito dos dados coletados, vale mencionar que a pesquisa realizada por Véronique Jagstaidt (1984) mostra resultados similares aos do presente trabalho. Contudo, diferentemente desta pesquisa, a autora organizou as respostas utilizando literalmente os estágios do artificialismo elaborados por Piaget, portanto não criou novos níveis para o domínio específico do conhecimento sobre sexualidade. Ainda que ela não tenha realizado análise quantitativa dos dados, na apresentação dos exemplos há elementos de conteúdo 
comuns às respostas das crianças entrevistadas no presente estudo e as afirmações das crianças francesas e suíças que ela entrevistou. Por exemplo: o elemento do anjo, a ingestão de comida fecundante, a participação duvidosa do pai na fecundação e as formas de explicar a alimentação intra-uterina.

Da mesma forma que no presente trabalho, a respeito das diferenças sexuais, Jagstaidt identificou o "recalque afetivo", noção que toma de Piaget para explicar os reiterados indicadores de vergonha e inibição, especialmente nas crianças de 8 anos. A respeito da psicanálise, Jagstaidt verificou traços de possíveis evidências fálicas e edípicas nas respostas das crianças mais novas, e características do período de latência nas mais velhas: pudor, vergonha e pensamento mais socializado.

Se, como afirma Piaget (1945/1975, p. 277), "não é o mesmo explicar as representações, que os mecanismos representativos", quais são os mecanismos representativos e aspectos psicodinâmicos que subjazem as crenças sobre a origem dos bebês? Analisar os "mecanismos representativos" implica não se contentar com o explícito da fala das crianças ou com o que é evidente. A elaboração dos níveis das crenças permite indagar modos de compreensão e interpretação a partir de traços comuns nas explicações. Como lembra Delval (2002), a maioria dos sujeitos está em processo de transição e não são exemplos paradigmáticos. Cada um apresenta uma coerência interna e mesmo as contradições são coerentes. Na elaboração dos níveis, é menos importante o conteúdo concreto do que o "como" os sujeitos dizem e as relações que estabelecem.

A respeito das diferenças sexuais, os dados mostram semelhanças com a pesquisa de Kohlberg (1966), sendo que elas podem ser mais objetivamente definidas pelas crianças mais velhas. De acordo com o autor, as dificuldades da criança em definir as constâncias da categoria da identidade de gênero são paralelas às dificuldades para estabelecer definições estáveis na conservação da quantidade de matéria e das dimensões dos objetos físicos em geral, ao longo do período das formas pré-operatórias do pensamento (ibid., p 94-95). Considerando a progressão genética piagetiana, Kohlberg afirma que se os modos básicos de organização cognitiva e as concepções do mundo mudam com a idade e o desenvolvimento, então as atitudes de papéis sexuais e a constância de gênero das crianças também têm aspectos universais que mudam com a idade. Desta forma, as tendências do desenvolvimento cognitivo-social são afirmadas como resultado das mudanças da experiência geral nos modos básicos de organização cognitiva.

Durante o período pré-operatório do pensamento, a sexualidade perturba com considerável intensidade em relação aos vários objetos do mundo e por isso leva a uma 
fecunda ação mental e física. A diferença sexual é um dos problemas afetivos e cognitivos ao qual a criança dará diferentes soluções de acordo com seu desenvolvimento. Segundo Freud, quando as crianças percebem a ausência do pênis rejeitam o fato e acreditam que vêem um. Essa contradição entre a observação e a pré-concepção da criança tem que ser encoberta. A criança supõe então que o pênis vai crescer e ainda é muito pequeno. Essa contradição entre fato e pré-conceito é uma constatação importante das pesquisas piagetianas sobre o período pré-operatório do pensamento. Por exemplo, na clássica prova piagetiana sobre a conservação da matéria, a criança observa que o experimentador não tira nem põe líquido nos copos, porém ela afirma que ao ser passado para outro recipiente com forma distinta do anterior, se produz uma alteração da quantidade de líquido, e agora o novo copo tem mais ou menos líquido que o outro. A criança não percebe a contradição entre a observação (de que nada foi tirado ou acrescentado) e sua afirmação de que a matéria foi alterada. Convergentemente, as duas deformações do percebido (a observação do pênis e do líquido) não se devem a problemas visuais das crianças, mas ao modo como se assimila o observado.

Em relação ao desenvolvido no item sobre aspectos sócio-históricos (cf. item 1.4), os dados mostram a presença dos seguintes elementos:

1- Sexismo (estereótipos de gênero);

2- O tabu do sexo: na escola oficialmente não se fala sobre isso enquanto que 'todo mundo fala no recreio', mas na entrevista pode dar vergonha;

3- Os adultos deformantes (teoria da semente, dos anjos) ${ }^{21}$;

4- A presença dos suportes midiáticos (filme, internet, televisão, ultrasom)

As respostas das entrevistas sugerem que a vergonha de falar sobre sexo ainda é forte no âmbito escolar e em algumas famílias, das quais as crianças recebem informações pouco realistas que fortalecem o artificialismo e a magia. Porém, esse fator social não é suficiente para explicar as reações de pudor das crianças. Esse fator se retroalimenta com um fator individual já apresentado no desenvolvimento psicossexual: os diques de vergonha e asco da latência postulados por Freud. Falar dos genitais provoca riso e demonstrações de incômodo. Em seu estudo sobre a vergonha, De La Taille (2002b) afirma que o riso pode ser uma forma de exprimir vergonha. Ele também assinala que a vergonha não deve ser confundida com o medo, distinção que aqui resulta interessante. Ainda que as entrevistas começassem com o esclarecimento de que as crianças podiam falar o que queriam e que não tinha resposta certa

\footnotetext{
${ }^{21}$ Nenhuma criança apelou à cegonha como elemento explicativo (somente uma mencionou a cegonha por ter assistido Dumbo há pouco tempo).
} 
ou errada, o fato de perguntar no contexto da instituição escolar pode ter mobilizado certo medo de "punição", caso elas mencionassem as palavras que são consideradas "ruins". Por exemplo, E41 (F 8,7), diante da pergunta sobre o nascimento, afirma: "Às vezes pode cortar a barriga, às vezes pode sair de um negócio que a gente não pode falar ( $r i)$ ”. Este autor assinala também que um dos sentidos da palavra vergonha alude à exposição, porque existe "certa suscetibilidade humana ao olhar alheio" que pode se fortalecer se há sentimentos de inferioridade ou baixa auto-estima.

Tanto nas perguntas sobre as diferenças sexuais e sobre a saída do bebê da barriga, a palavra vagina e pênis eram evitadas e substituídas por outros nomes. Os dados mostram que o vocabulário sexual utilizado pelas crianças de 7 a 9 anos é diverso. No caso do pênis: "aquele negocinho", “o pirulim", "pintinho", "pipi”, "pirulito" “onde faz xixi”, "pinto”. No caso da vagina: "a parte íntima”, "perereca”, “o sexo”, "periquita”. Para se referir a ambas, muitas crianças apelam a assinalar entre suas pernas dizendo "aqui". Em resumo, do total de 22 crianças que respondem de acordo com o nível de crenças realistas para explicar as diferenças sexuais, somente 5 se referem à "vagina" utilizando esse nome e 2 mencionam a palavra "pênis".

Vale ressaltar que em uma das escolas em que ficou evidente esse excessivo pudor e inibição para falar das diferenças sexuais e do nascimento pela vagina, a diretora tinha informado que os alunos mostravam especial interesse pelo sexo nos intervalos. Durante o recreio eles brincavam com uns bonecos de decoração do quintal, fazendo poses que imitavam relações sexuais entre, por exemplo, uma joaninha e um gnomo. Porém, a escola não realizava nenhum tipo de projeto ou intervenção de educação sexual. Portanto, nessa escola talvez a sexualidade continue sendo "explorada" nos intervalos a partir dos recursos cognitivos e afetivos dos próprios alunos.

A respeito dessa situação específica, vale lembrar Colette Soler (cf. item 3.5) quando afirma que "com a evolução dos costumes, a televisão e a educação sexual, revela-se hoje às crianças o que eu chamaria de gestualidade do ato sexual" (Soler 2002, p. 11, o negrito é nosso). Pareceria que se a gestualidade já é bem conhecida, o simbólico ainda não se vincula aos conhecimentos sexuais. Onde ainda não há palavras, há gestos; gesticular é permitido, mas na proposta de falar sobre isso a criança não consegue se autorizar. Talvez uma possível discussão a respeito da contínua "informação sexual" à qual as crianças são expostas, seja acerca da sua qualidade, quando ela não passa de imagens e gestos dos quais "não se pode falar". 
A respeito da teoria falocêntrica, a leitura da "ausência do pênis" nas mulheres pode ser relativizada e entendida no contexto do raciocínio freudiano, levando em consideração a bissexualidade constitutiva de origem. A proposta de Freud acerca da concepção das diferenças sexuais durante a etapa fálica é dialética. Em relação ao menino, ao mesmo tempo a menina "tem" e "não tem". Assim, a inveja do pênis se origina na "falta", mas antes e depois dessa falta a menina "tem": primeiro um pênis pequeno, e logo o potencial de dar nascimento a um bebê.

Essas teorizações acerca das diferenças sexuais permitiriam abordar, nas respostas dadas pelas crianças, a recorrente ausência de uma função masculina específica para a procriação e a tendência a conceber a mulher como elemento auto-suficiente para gerar um bebê. A dificuldade de conceber a existência de espermatozóides somada a idéia de Abraham de que a mulher compensa a falta de um pênis grande por seios maiores aos masculinos também ajudaria a reforçar essa idéia. A equação simbólica (pênis = bebê, ou em outras palavras, "homem tem pênis, mulher tem bebê") poderia estar dificultando a construção da idéia da participação do sexo masculino com caráter de "necessidade lógica" e não contingente para a reprodução da espécie.

Para além da idéia de que na menina "falta algo", a teoria falocêntrica pode ser pensada como uma proposta mais ampla se é considerado o "fragmento de verdade" que Freud vislumbra nela: é verdade que todos têm pênis porque a menina tem um clitóris (de percepção visual muito mais sutil) com função anatômica análoga ao pênis em termos de prazer. Ao mesmo tempo, a criança ainda não atingiu a inclusão de classes própria do pensamento operatório, que lhe permitirá classificar por critérios lógicos e já não contingentes ou arbitrários. Essa experiência cognitiva e afetiva poderia ser entendida em termos universais no contexto do narcisismo e do egocentrismo infantil. Portanto, "se todos têm pênis = clitóris, então todos experimentam como eu". O egocentrismo pode ser pensado como um processo que se corresponde com o falocentrismo. Ambos são conceitos amplos, integradores da inteligência e da afetividade, e explicativos do ponto de vista do desenvolvimento, tanto em termos de gênese como de estrutura.

A tendência observada nos dados coletados mostra que as crianças de 7 a 9 anos não suspendem radicalmente toda menção à sua própria experiência, mas diferentemente das mais novas, ela já não resulta a referência absoluta para explicar os fenômenos biológicos sobre os quais são indagados e sim, uma fonte a mais de informação entre outras. A socialização do pensamento foi confirmada a partir das respostas das crianças mais velhas que mostram conhecimentos mais objetivos e descentrados. Essa evidência poderia ser indicador de uma 
dupla "queda" de processos correspondentes. Por um lado, da deificação dos pais postulada por Piaget e por outra, da onipotência do pensamento. A deificação que prevalece no período pré-operatório e na fase fálica, será desfeita progressivamente por volta dos 6 anos quando a criança percebe que os pais também podem errar, ignorar muitas coisas ou cometer injustiças (Piaget, 1926/2005).

Essa crise da deificação (ou crise de ceticismo) também pode ser entendida a partir de uma das bases da psicanálise: toda renúncia ao prazer só tem lugar sobre a base de uma troca. Durante o desenvolvimento psicossexual, um exemplo disso é lembrado por Abraham (1921/1985, p. 85), o qual assinala que na fase anal a criança deve se adaptar às exigências da educação e aprender a reter suas excreções, o que constitui uma novidade que também será acompanhada por prazer. Se a deificação dos pais (uma das causas das crenças mágicas e précausais sobre a origem dos bebês) dava segurança e conforto à criança, qual é a troca que se produz quando estas "evidências" que garantem a satisfação se diluem? Essa satisfação pode ser "deslocada" para a escola, os objetos da cultura em geral e os professores nos quais a criança transfere seus sentimentos filiais (tema estudado por Freud especialmente no texto "Psicologia do Escolar" como fenômeno de transferência). A escola resulta um "palco" de socialização do pensamento por excelência. Porém, esse processo de crise de ceticismo pode levar a percursos singulares dependendo do que Freud nomeou como "os três destinos da pulsão de saber" (cf. item 3.5). Em resumo, se para Piaget "o pensamento é disciplinado pela vida social" (ibid., p. 163); algo similar ocorre para a psicanálise com as frustrações que a cultura impõe às crianças (por exemplo, a proibição do incesto).

Na perspectiva psicanalítica, Freud (1914/1996) afirma que enquanto as pulsões autoeróticas são originárias, uma unidade comparável ao Ego não está presente no indivíduo desde o início, mas precisa antes ser desenvolvida a partir de um "novo ato psíquico". Esse ato acrescentado ao auto-erotismo permite a constituição do narcisismo, como fase intermediária entre o auto-erotismo e o amor objetal. $\mathrm{O}$ amor objetal constitui um tipo de escolha por veiculação sustentada sendo que a criança toma seus objetos sexuais a partir de suas experiências de satisfação. À diferença de Piaget, a psicanálise infere o narcisismo infantil a partir do trabalho com adultos. Freud (1914/1996) argumenta que no indivíduo adulto típico pode se observar um antigo delírio de grandeza infantil mitigado e caracteres apagados dos quais se deduz o narcisismo infantil. A atitude narcísica da criança é contemporânea à dos povos primitivos nos elementos da magia, onipotência dos pensamentos, poder mágico das palavras e supervalorização da potência de seus desejos. Sobre o narcisismo infantil Freud 
assinala que "a graça da criança reside, em grande parte, em sua auto-suficiência e em sua inacessibilidade (1914/2004, p.108)".

A correspondência entre as fases da evolução da onipotência das idéias assinalada por Freud (Totem e Tabu, 1913) e as fases do artificialismo elaboradas por Piaget se verifica nas crenças egocêntricas e mágicas das crianças mais novas entrevistadas na presente pesquisa. A cosmovisão animista postulada por Freud (cf. item 3.5) é a mais rica em consequiências na vida atual: desvalorizadas nas formas de superstição, ou vivas como base da nossa fala, crenças e filosofias. Esse primeiro sistema cosmológico (fase correspondente ao narcisismo e às características das produções simbólicas das crianças) não surgiu pelo mero apetite de saber, mas por uma necessidade prática de se apoderar do mundo (por exemplo, como formas de feitiçaria e magia).

O pensamento animista, também corroborado nas falas das crianças, implica a supressão ou negação do fortuito. Essa tendência constatada nas entrevistas pode ter relação com certa dificuldade da criança de atribuir uma causalidade física ao nascimento de um bebê (em contraposição à pré-causalidade). Algumas crianças acreditam que, para um bebê nascer, pode bastar com que alguém o deseje, e o sexo do bebê pode depender da vontade dos pais ou de Deus. A respeito disso, Piaget argumenta que a distinção entre ações intencionais e movimentos mecânicos não é inata e que "nenhuma experiência positiva pode, com efeito, obrigar um espírito a admitir que as coisas não sejam nem para nós, nem contra nós, e que o acaso e a inércia reinam na natureza" (Piaget 1926/2005, p. 191). Segundo Freud, o mito descansa em premissas animistas e isso significa que não precisa da ciência como fundamento porque

(...) a ciência só nasce quando se compreende que não se conhece o mundo e por isso tem que buscar caminhos para tomar conhecimento dele. Assim, o animismo era para o homem primitivo algo natural e evidente por si mesmo; sabia como são as coisas do mundo: são como o homem se sente a si mesmo (Freud, 1913/1989, p. 94).

Parafraseando a citação de Freud em relação ao egocentrismo infantil postulado por Piaget, poderia se afirmar que a criança acha que sabe como são as coisas do mundo porque sua tendência animista o apresenta como evidente e natural. Assim, sem a necessidade de verificação, as coisas do mundo são como a criança se pensa e se sente a si mesma, estando ainda longe de aceitar sua ignorância (que poderia ser pensada em termos de falta e castração), sendo que as próprias crenças artificialistas obturam qualquer possibilidade de dúvida. As teorias sexuais infantis (falocêntrica, cloacal e do sadismo no coito) são testemunhos desta afirmação, por serem construídas pela criança com base nas experiências 
de seu corpo e na própria angústia projetadas no mundo sem nenhuma necessidade de verificação. Porém, é necessário lembrar a atemporalidade da lógica do inconsciente, e que, sendo o infantil um núcleo sempre presente no sujeito, o narcisismo não constitui uma fase a superar, mas um traço que continuará presente com maior ou menor força.

A tendência do pensamento narcisista foi manifestada nas entrevistas com as crianças mais novas por uma opinião ingenuamente excessiva de si mesmas ("eu sou inteligente", "eu nasci sabendo") e a crença na onipotência do pensamento. Esta característica da infância prevalece especialmente na imaginação e na necessidade de se impor e falar de si mesmo (inclusive de intimidades) com desconhecidos, enfatizando sempre as próprias opiniões. A criança gosta que o outro esteja ciente da sua beleza interior e das suas capacidades, como uma espécie de exibicionismo psíquico (Piaget 1920/1994, p. 91).

$\mathrm{Na}$ ótica freudiana (1914/1996), o desenvolvimento do Ego consiste em se afastar do narcisismo deslocando a libido sobre um ideal do Ego exterior. Assim, a satisfação já não provém exclusivamente do próprio corpo, mas do cumprimento do ideal. O desenvolvimento do narcisismo possibilita a instauração do Ego ideal, que recebe o amor por si mesmo desfrutado pelo Ego verdadeiro. Ou seja, há um deslocamento do narcisismo porque esse Ego ideal será posse de toda a valiosa perfeição e completude do Ego infantil.

$\mathrm{Na}$ fase intermediária entre o auto-erotismo e o amor objetal são construídas as teorias sexuais infantis a partir de tendências pulsionais e, portanto na fantasia. A fantasia, distante do conhecimento científico e objetivo, foi amplamente observada nas crenças das crianças mais novas, nas suas tendências à fabulação e à magia (p. ex. "o anjinho coloca o bebê na barriga"). A partir dos aportes freudianos $(1908,1911,1913,1914)$ sobre essa construção específica, podem ser destacados alguns aspectos gerais necessários para entrar em uma cosmovisão científica regida pelo princípio de realidade e, portanto, mais adaptada e descentrada. Da leitura dos trabalhos de Freud surgem fatores notáveis que colaboram nesse processo: 1) a educação, cujo papel central na latência está em relação à exogamia e a dissolução do complexo de Édipo; 2) o início da capacidade de juízo segundo o princípio de realidade; 3 ) o apagamento do narcisismo infantil (perfeição e completude) e a conseqüente admissão do desconhecimento do mundo (queda da onipotência); 4) a função especial da sublimação em correlação à formação do ideal do Ego.

Também na perspectiva piagetiana, o papel dos pais é um fator que explica as soluções artificialistas. A criança entende que seus pais têm a ver com seu nascimento, mas não consegue explicar de início, o "como" e o "para que" dessa situação. Piaget propõe que: 
(...) o problema do nascimento é, mais uma vez, o problema do papel dos pais. A criança sente pertencer a seus pais, sabe que os pais determinaram sua vinda. Para quê? Como? A orientação desse interesse condiciona uma boa parte das suas soluções artificialistas (Piaget, 1926/2005, p. 309).

Nessas perguntas que a criança tenta resolver há convergências afetivas com a proposta da psicanálise. O problema da origem dos bebês representa de modo manifesto a preocupação pelo lugar que os pais lhe deram e o lugar que atualizam, e que, portanto funciona como desejo-motor da pesquisa sobre o nascimento. Especialmente se a criança suspeita ou vivencia a chegada de um irmão a pergunta latente é pelo desejo dos pais.

Segundo Piaget (1926/2005), as crianças têm de início o sentimento da ligação dos bebês com os pais: sentem que estes têm um papel essencial na vinda dos bebês, seja porque os pais encomendaram, procuraram ou construíram alguma coisa. Mais tarde a criança inventa mitos para explicar a si mesmo esse sentimento: os pais fabricaram o bebê. Portanto, o sentimento de ligação precede o mito e o faz surgir. Quando a criança tenta sistematizar os sentimentos de participação recorre aos mitos animistas e artificialistas (ibid, p. 211).

Como se da essa passagem para a construção de mitos ou crenças artificialistas? Se para Piaget o desenvolvimento do sujeito tende ao equilíbrio (mas sempre passando por instâncias de desequilíbrios cognitivos), para Freud o aparelho psíquico e suas instâncias psíquicas (Ego, Superego, Id) constituem uma fonte de conflitos irredutíveis. Contudo, na perspectiva piagetiana, são os desequilíbrios decorrentes da adaptação ao meio que provocam no pensamento da criança uma transição entre o símbolo e a lógica. Essa transição foi assinalada por Piaget em 1923 a partir de numerosas analogias funcionais entre o pensamento da criança e o pensamento simbólico ou inconsciente.

A partir das expressões "pensamento simbólico", "pré-consciente" e "autístico" que toma da psicanálise (e que propõe como sinônimos) Piaget visa assinalar pontos de contato com as características do pensamento pré-operatório da criança. O pensamento simbólico referido por Piaget é o pensamento inconsciente, especialmente dos sonhos, fundado a partir de mecanismos próprios dos processos primários, como a condensação e o deslocamento (vale lembrar aqui os processos primários em relação aos secundários, cf. 3.2). Ele é dificilmente comunicável, mas participa também em formas semi-sociais como a imaginação artística, mística e mitológica.

O pensamento da criança seria intermediário entre o pensamento simbólico e o lógico. Três características desse último são compartilhadas com o pensamento da criança: ausência de ilação lógica, predomínio da imagem sobre o conceito e falta de consciência das conexões 
que unem a sucessão de imagens (Piaget 1923a/1994). Ambos, o pensamento da criança e o simbólico não são contrários ao pensamento lógico, mas um começo das suas formas primitivas. Ainda que o autor focalize as analogias funcionais ou estruturais entre esses tipos de pensamentos, às vezes eles também podem ser análogos na perspectiva do conteúdo como no caso das teorias do nascimento que reaparecem na temática dos sonhos dos adultos.

A novidade da proposta piagetiana consiste em evitar centrar-se em analogias entre a imaginação ou a afetividade da criança e o pensamento simbólico inconsciente do adulto. $\mathrm{O}$ objetivo de Piaget (ibid) é mostrar que a inteligência da criança participa da lógica do simbolismo. Para isso, postula as analogias funcionais. Uma delas faz referencia à direção do pensamento. No caso dos sonhos e dos delírios, o pensamento é caótico e não dirigido porque não ordena as representações em seqüência. Sua direção é afetiva, já que um mesmo desejo agrupa as imagens. Analogamente, uma direção relativa e frágil se manifesta no pensamento das crianças de até 7/8 anos, porque um mesmo problema não a ocupa por mais de 15 minutos e sua atenção se desloca constantemente. Assim, seu pensamento é intermediário entre o dirigido e o não dirigido, e em comparação com o pensamento adulto, é menos consciente de si mesmo e das conexões dos juízos sucessivos.

Na obra A formação do símbolo na criança, Piaget (1945/1975, p. 221) afirma que "se o resultado de todo trabalho mental é consciente, o mecanismo mesmo dele permanece oculto". De modo semelhante a Freud, o inconsciente cognitivo na perspectiva piagetiana não é uma região isolada do espírito, porque "todo processo psíquico marca uma passagem contínua e ininterrupta do inconsciente à consciência e vice-versa" (ibidem). Piaget (1970b/1983) aprofunda as diferentes naturezas entre o inconsciente psicanalítico e o cognitivo ao sustentar que esse último não comporta conceitos como representação porque considera que a noção de "representação inconsciente" resulta contraditória. Sendo assim, volta a enfatizar que "os mecanismos afetivos e cognitivos permanecem sempre indissociáveis se bem que distintos, e isso é evidente se uns dependem de uma energética e outros de estruturas" (ibid, p. 234).

Se existe um caráter indissociável da afetividade (como energética) e da estrutura (como forma) na construção dos conhecimentos em geral, que papel desempenha a afetividade no problema específico do nascimento dos bebês? Como se desenvolve sua função energética nesse campo? Para dar resposta a essas perguntas é preciso voltar às origens do artificialismo, mas desta vez focalizando os fatores afetivos e, especialmente, o papel dos pais no seu surgimento. Piaget afirma que a participação antropocêntrica constitui o núcleo do artificialismo espontâneo, "e ainda seria necessário supor que na criança este núcleo é composto por simples sentimentos ou simples atitudes mentais" (Piaget, 1926/2005, p. 287). 
Enquanto que as causas individuais parecem mais importantes no caso da magia e do animismo, as causas sociais parecem ter a primazia no caso do artificialismo.

Para explicar os fatores individuais que determinam a origem do artificialismo, Piaget considera três questões. A primeira é que tal como foi demonstrado pela psicanálise o pensamento da criança toma forma a partir de interesses narcisistas e auto-eróticos (que têm por foco todas as funções orgânicas, especialmente as digestivas e de micção). Na mesma medida, o pensamento é moldado pelos complexos parentais. Em segundo lugar, destaca o fato de que o pensamento da criança está intimamente ligado à sua atividade muscular. Por último, destaca o papel da linguagem que permite a expressão "fazer fazer", por exemplo: "o vento faz fazer avançar as nuvens" (Piaget, 1926/2005, p. 307-308).

Entre as causas sociais, destaca o vínculo afetivo da criança com seus pais. Na perspectiva da criança, toda a natureza converge em redor dela e foi organizada pelos pais ou pelos homens em geral. Ela mesma experimenta uma dependência imediata da atividade dos pais. Durante o estágio do artificialismo difuso prevalece o sentimento de dependência material. No mitológico, o problema é o papel dos pais. Outra tendência dos sentimentos das crianças em relação aos seus pais é a já comentada "deificação". O amor filial supõe nos pais qualidades e virtudes tais como santidade, onipotência, eternidade e onisciência. Piaget (ibid, p. 305) explica que essa crença infantil é implícita, não formulada ou mesmo não formulável, porém é no dia que a crença desaba que se percebe que existia.

Em decorrência disso surge uma "crise de ceticismo" em relação ao pensamento adulto. Esse fato tem a maior importância para o pensamento da criança porque a partir daí ela estará próxima de admitir o acaso e as explicações naturais. Neste ponto, uma leitura convergente pode se estabelecer em relação ao desenlace do Complexo de Édipo como início da exogamia, da autonomia intelectual e de um maior investimento de objetos do contexto social para além dos familiares a partir do mecanismo da sublimação. A renúncia à onipotência paterna seria condição necessária para a construção da ciência e a abertura aos objetos sociais. Nas palavras de Freud:

\begin{abstract}
o menino começa a vislumbrar o mundo exterior e não pode deixar de fazer descobertas que solapam a alta opinião original que tinha sobre o pai e que apressam o desligamento de seu primeiro ideal. Descobre que o pai não é o mais poderoso, sábio e rico dos seres; fica insatisfeito com ele, aprende a criticá-lo, a avaliar o seu lugar na sociedade (Freud, 1914b/1996, p. 249).
\end{abstract}

Esses sentimentos podem ser deslocados na figura de Deus, presente em muitas das respostas das crianças. Deus será um elemento de transição caso a criança consiga explicar a fecundação a partir de um pensamento lógico. A concepção das crianças sobre Deus já foi 
comentada em relação ao desenvolvimento do artificialismo proposto pela psicogênese piagetiana como "uma Paternização desse homem forte ou chefe dos homens". Da mesma maneira, para Freud "um Deus pessoal nada mais é, psicologicamente, do que uma exaltação do pai" (Freud, 1910/1996, p. 129). Diante do exposto, uma conclusão importante para destacar é que o sentimento filial é fonte de artificialismo. Entretanto, Piaget não distingue um artificialismo humano de um divino ou teológico. É um só porque as crianças interpretam que Deus é um senhor, o chefe dos homens, ou os homens são Deus, mas sempre por transferência dos sentimentos filiais.

A entrada no período de latência implica o recalcamento da sexualidade infantil, o que explica que seja o palco de um conflito estrutural. O complexo nuclear das neuroses se constitui no conflito psíquico entre a autoridade parental e as teorias sexuais infantis (que deverão ser recalcadas) e esse conflito deixa marcas no sujeito em relação à construção do saber no futuro. Em decorrência disso, poder-se-ia falar de um aspecto cognitivo do Complexo de Édipo, ou de uma fase edípica do desenvolvimento cognitivo. Quais são os aspectos "psíquicos" do desenvolvimento psicossexual freudiano? Talvez a dimensão sexual sempre fique mais clara e explícita, porém desentranhar o desenvolvimento "psico" possibilita um esforço de leitura maior dentro da própria psicanálise além da consideração dos aportes de outras teorias como a psicogênese piagetiana. Freud esclarece que

\footnotetext{
a psicanálise jamais se esqueceu de que há também forças pulsionais que não são sexuais. Ela se baseou numa nítida distinção entre as pulsões sexuais e as pulsões do Ego, e, apesar de todas as objeções, sustentou não que as neuroses derivavam da sexualidade, mas sim, que sua origem se deve a um conflito entre o Ego e a sexualidade (Freud, 1916/1996, p. $354)$.
}

Assim, o complexo de Édipo marca ou modela uma posição no mundo, que resulta mais abrangente que nos aspectos sexuais e afetivos. Não remete só ao desenvolvimento sexual, porque na dimensão "psico" do desenvolvimento "psicossexual" teorizado por Freud, funda-se uma modalidade de interação com os objetos do meio, com o conhecimento e com a exploração de novidades, possibilitando ritmos e intensidades nas equilibrações gerais da adaptação (assimilação-acomodação ao meio).

Abordar a afetividade em termos energéticos, de interesse e motivação, a partir do referente teórico piagetiano, possibilita considerar a dissolução do complexo de Édipo como um processo pulsional de suma importância para entender a progressão qualitativa da construção do conhecimento. A abordagem freudiana da construção das teorias sexuais infantis resulta especialmente dialética e exemplar da sua concepção de desenvolvimento psicossexual. O estudo sobre as teorias sexuais das crianças remete à mesma lógica 
apresentada no construto teórico das "séries complementares" desenvolvido para explicar a etiologia das neuroses. Freud não se posiciona nem na tradição inatista, nem empirista. A construção dessas teorias é o resultado de um complexo processo no qual intervém aspectos endógenos e exógenos.

A respeito da importância dos sentimentos filiais nos esquemas afetivos, Piaget (195354/1994) está de acordo com Freud na postulação de que a afetividade se centra nos pais desde muito cedo, com sentimentos diversos e ambivalentes. Assim, a transferência é entendida como a atribuição dessas modalidades afetivas a outras pessoas (por exemplo, a professores). Os mecanismos freudianos destacados por Piaget para essa atribuição são: a fixação do inconsciente ao passado (porque a afetividade é uma energia que se desloca) e a identificação com algum dos pais. A transferência dessas modalidades é aceita por Piaget, enfatizando que os sentimentos não se conservam idênticos, mas se reconstroem. O que se conserva para Piaget é um esquema de reação diante das pessoas. O sentimento é re-criado e reconstruído em cada ocasião. Vale aqui um último esclarecimento para entender a definição piagetiana de esquema afetivo:

\footnotetext{
Ao falar de esquema afetivo não queremos dizer que existam esquemas da afetividade como existem esquemas cognitivos: isso significaria efetivamente reintroduzir uma dicotomia que temos negado constantemente, ou estender abusivamente a noção de esquema. Em realidade, existem esquemas de conduta diante das pessoas como existem diante dos objetos, e esses esquemas são, nos dois casos, por sua vez cognitivos e afetivos (Piaget, 1953-54/1994, p. 257).
}

O esquematismo afetivo tem o vínculo com os pais como ponto de partida, e somado ao esquematismo cognitivo constituem o caráter do sujeito. $\mathrm{O}$ esquema afetivo pode ser definido como um instrumento de generalização e um modo de reação diante das pessoas que pode se repetir. Em 1945 já tinham sido definidos por Piaget como resumos ou moldes de diversos sentimentos sucessivos que cada um dos personagens do meio ambiente provoca. Eles determinam os principais símbolos secundários (inconscientes para o sujeito) como as preocupações íntimas e os desejos secretos freqüentemente inconfessáveis. Nas crianças, os símbolos secundários comportam em particular três grupos: "os que conduzem aos interesses ligados ao corpo propriamente dito (sucção e excreção), os que se referem aos sentimentos familiares elementares (amor, ciúme e agressividade) e os referentes às preocupações centradas sobre o nascimento dos bebês" (Piaget, 1945/1975, p. 222). O problema do nascimento é bem complexo segundo Piaget porque "ultrapassa a moldura de um simples problema de inteligência causal" e ocasiona todo um simbolismo lúdico (secundário). Antes de achar a solução, a criança "simboliza diversas possibilidades fantasiosas" (ibid, p. 226). 
Há paralelismo entre o desenvolvimento afetivo e a evolução do pensamento porque sentimentos e operações intelectuais estão presentes em toda atividade psíquica. Dizer que no período pré-operatório os sentimentos e o intelecto permanecem egocêntricos, significa que preferem a satisfação do Eu à verdade (Piaget, 1933/1994). Essa afirmação pode ser relacionada com a idéia freudiana de que é a frustração dos desejos da criança que conduz à prevalência do princípio de realidade, em detrimento do princípio de prazer.

Em resumo, e tal como os dados apresentados no capítulo anterior mostraram, a direção seguida pelo pensamento pré-operatório é a da imaginação e não a da pesquisa. A criança pode-se contradizer sustentando teses contrárias com minutos de separação, e esquecer rapidamente o que afirmara. Por sua vez, tem dificuldades para manejar as relações de partetodo e a sua lógica está dominada pela necessidade de satisfação imediata mais que pela necessidade de verdade (Piaget, 1923/1994). As crenças sobre a origem dos bebês das crianças mais novas verificam esse pensamento intuitivo, intermediário entre a imagem e o conceito, que "só representa imaginando, por oposição à lógica que representa pela dedução das relações" (Piaget, 1945/1975, p. 273). 


\section{CONSIDERAÇÕES FINAIS}

Refletir sobre as teorias sexuais infantis contextualizadas a partir da perspectiva piagetiana do artificialismo, animismo e finalismo (desenvolvidos anteriormente como tendências gerais do pensamento) permite ampliar a compreensão dos processos da sua construção. Simultaneamente, possibilita entender de maneira mais aprofundada o argumento freudiano de que a construção de uma crença que justifique as diferenças sexuais e explique o nascimento "se imponha" às crianças. Essa imposição é dupla: pulsional e por estrutura do pensamento. Os dados aqui apresentados levam a pressupor que ainda que se ofereça uma explicação didática e muito completa sobre a origem dos bebês, esta não se imprime mecanicamente no psiquismo infantil, mas é assimilada por suas estruturas. Assim, continua sendo elaborada e reconstruída de acordo com as estruturas do pensamento e os fatores afetivos que influenciam cada etapa do desenvolvimento da criança. Os princípios teóricos norteadores desta pesquisa corroboram essa idéia.

Dos elementos levantados neste estudo, constatou-se que nas crianças mais novas os processos primários e as formas pré-operatórias do pensamento prevalecem em maior medida que nas mais velhas. A maioria das crianças de 4 a 6 anos assimilam o problema da origem dos bebês egocentricamente, ou seja, a partir da intuição perceptiva e de relações imediatas. Os dados mostram que as crianças mais velhas estariam organizando suas idéias acerca do nascimento a partir das possibilidades ofertadas pelas operações lógicas e pelo período de latência (descentração, coerência, sublimação das pulsões sexuais, investimento de objetos da cultura e diques como vergonha e nojo). No grupo das crianças de 7 a 9 anos, os pensamentos mais socializados manifestam-se como possível conseqüência, entre outros fatores, da descentração do egocentrismo, do início da organização do pensamento em um sistema coerente de relações objetivas, da noção de conservação da substância, da assimilação racional, da consolidação dos processos secundários (em detrimento da hegemonia dos primários) e da dissolução do complexo de Édipo.

Considerando que o desenvolvimento da afetividade se correlaciona com a energética da ação e o da inteligência com a sua forma, ambas seriam como as duas faces da mesma moeda na construção do conhecimento. Sendo assim, as crenças sobre a origem dos bebês são escolhidas como tema preponderante de ocupação intelectual e afetiva das crianças pequenas porque constituem um conteúdo de especial interesse e motivação mental e pulsional. Por sua vez, esse conteúdo é assimilado a partir de uma forma de pensamento, portanto as crenças são 
construídas e modeladas com base em esquemas pré-operatórios ou operatórios e com suas correspondentes características de assimilação.

As crenças sobre a origem dos bebês mostram que os mecanismos simbólicos e préconceituais do pensamento convergem com a prevalência dos processos primários regidos pelo princípio de prazer postulados por Freud para explicar o desenvolvimento psíquico das crianças mais novas. A entrada no pensamento lógico é também correspondente com as possibilidades instauradas no período de latência.

A criança pequena explica e entende o mundo segundo a sua preferência (princípio de prazer) e sua situação familiar. Na "dissolução" do complexo de Édipo subjaz a aceitação relativa de uma diferença que existe para além das explicações que se possam elaborar em torno delas. A diferença sexual e a relativização do amor incondicional e da onipotência dos pais (crise de ceticismo) são fatos objetivos a respeito dos quais a criança aprenderá que não podem ser totalmente controlados. Progressivamente, a sua adaptação ao princípio de realidade lhe permitirá abrir a um mundo objetivo e complexo no sentido de que funciona independentemente da sua vontade ou de seus pais, onde o acaso e o fortuito produzem efeitos para além das preferências humanas. Ainda que essa "falta" de certeza que amparava à criança e garantia a sua segurança possa gerar angústias, ela também abre infinitas possibilidades de percursos e projeções a partir de uma mudança na sua concepção do mundo e de si mesma: se ela não sabe tudo e as aparências perceptivas podem enganar, então conhecer o mundo "objetivo" se apresentará como um desafio contínuo, e no melhor dos casos, pode resultar em outra forma de obter prazer, mas desta vez, via princípio de realidade.

A passagem do pensamento pré-operatório ao operatório concreto permite que a criança construa a lógica, coordene pontos de vista e se inicie no percurso da autonomia intelectual e afetiva (em contraposição ao principio de heteronomia que subjaz nas condutas das crianças mais novas). A diminuição da prevalência das condutas impulsivas, crédulas e egocêntricas características do pensamento intuitivo lhe permitirá pensar melhor antes de atuar. A construção das operações trará com ela a conquista do princípio de reflexão. Em outras palavras, na perspectiva piagetiana, a criança poderá deliberar interiormente em uma discussão consigo mesma porque a reflexão constitui uma conduta social interiorizada. Por sua vez, a discussão socializada é uma reflexão exteriorizada e, portanto, Piaget (1964/1975) conclui com a idéia de que toda conduta humana é, ao mesmo tempo, social e individual.

A tentativa de diálogo entre a psicogênese piagetiana e a psicanálise foi justificada por um problema cuja abordagem se viu beneficiada, ampliada e enriquecida a partir dele. Assim, aumenta as ferramentas teóricas para abordar a interação de um tipo de sujeito específico 
(crianças de 4 a 9 anos) que constrói significados ao assimilar um determinado objeto com características singulares (a sexualidade e a origem). O aprofundamento desse diálogo também pode continuar beneficiando trabalhos do campo da psicologia do desenvolvimento, escolar e da clínica. O enriquecimento mútuo dessas teorias para o estudo e compreensão do desenvolvimento das crianças foi sustentado por Piaget, sugerindo que a psicologia da inteligência e a psicanálise devem se fundir em uma teoria melhor, encorajando assim à pesquisa das "relações que podem existir entre as duas" (cf. epígrafe).

Como já foi mencionado, este trabalho não pretendeu realizar essa fusão, mas tentou ao menos um diálogo para abordar o objeto de estudo da pesquisa à luz das relações existentes entre alguns conceitos de ambos os corpos teóricos. A abordagem da construção das crenças sobre a origem dos bebês abre uma discussão a partir da validade de uma dupla concepção de sujeito: epistêmico e do inconsciente. O problema do conhecimento sexual problematiza as concepções dicotômicas ou fragmentárias e reafirma as idéias piagetianas e freudianas de um desenvolvimento integrador dos fatores cognitivos e afetivos. Em contrapartida, essas perspectivas acrescentam não poucas dificuldades na sua abordagem. Contudo, este estudo se enquadra na posição teórica, metodológica e ética de que a complexidade do sujeito, longe de ser um obstáculo a diluir, merece ser considerada e valorizada nos estudos do desenvolvimento humano, na clínica, na escola e no âmbito acadêmico em geral para evitar reducionismos e pressões didáticas que, com o intuito de esclarecer, classificar e ordenar, só empobrecem o estudo do desenvolvimento humano.

Com base nos resultados aqui obtidos acerca da construção das crenças sobre a origem dos bebês, pode se concluir que as tentativas de uma articulação sólida e consistente entre as perspectivas piagetiana e freudiana dão lugar a novas discussões, novos problemas de pesquisa, e também novos olhares para antigas perguntas a respeito do desenvolvimento cognitivo e afetivo da criança. 


\section{REFERÊNCIAS $^{22}$}

ABRAHAM, K. (1913/1980). Efectos psíquicos producidos en un niño de nueve años por La observación de las relaciones sexuales entre sus padres. In. Psicoanálisis Clínico. Buenos Aires: Paidós.

(1916/1985). La primera etapa pregenital de la libido. In. Contribuciones a la teoría de la libido. Buenos Aires: Ed. Hormé/Paidós.

(1920/1980). Manifestaciones del complejo de castración femenino . In. Psicoanálisis Clínico. Buenos Aires: Paidós.

(1921/1985). Contribuciones a la teoría del carácter anal. In. Contribuciones a la teoría de la libido. Buenos Aires: Ed. Hormé/Paidós.

(1925/1980). Una teoría sexual infantil no observada hasta ahora. In. Psicoanálisis Clínico. Buenos Aires: Paidós.

(1925/1985). La influencia del erotismo oral sobre la formación del carácter en el nivel genital del desarrollo de la libido. In. Contribuciones a la teoría de la libido. Buenos Aires: Ed. Hormé/Paidós.

ARIES, P. (1973). Historia social da criança e da família. Rio de Janeiro: LTC, 1981.

BENBENASTE, N. (2005). La epistemología genética como ciencia. In: Benbenaste, N. (org.) El sujeto del conocimiento válido. Buenos Aires: Ediciones Cooperativas.

BERGÈS J. e BALBO,G. (2001). A Atualidade das Teorias Sexuais Infantis. Porto Alegre: CMC Editora.

BERMUDO, J. M. (1978). La expansión del paradigma mecanicista y el desarrollo desigual y combinado de las ciencias. In. Cuadernos de Geografía Humana. Año III, Número: 15 Universidad De Barcelona (ISSN: 0210-0754)

BRINGUIER, J. C. (1977). Conversaciones con Piaget. Barcelona: Gedisa, 2004.

BROUGÈRE, G. (1999). Les expériences ludiques des filles et des garçons. In: Filles et Garçons Jusqu'a l'adolescence, Paris, L'Harmattan.

CALDERONE, M. e RAMEY, J. (1986). Falando com seu filho sobre sexo. São Paulo: Summus.

CAMARGO, A. E RIBEIRO, C. (1999). Sexualidade(s) e Infância(s). A sexualidade como um tema transversal. Campinas/São Paulo: Ed. da UNICAMP/Ed. Moderna.

CAPANNA, P. (2004). La guerra de los homúnculos. In. Página/12, Suplemento futuro, Sábado, 3 de enero de 2004.

\footnotetext{
${ }^{22}$ De acordo com o estilo APA - American Psychological Association
} 
CHAUI, M. (2010) Convite à filosofia. São Paulo: Ática.

CHILAND, C. (1993). Homo Psychanalyticus. Rio de Janeiro: Ed. Bertrand Brasil

COELHO JR, N. (2002). Variações do lugar de objeto na psicanálise freudiana. In: Simão, L.M.; De Souza, M.T.C.C. e Coelho, N. Noção de objeto, concepção de sujeito: Freud, Piaget e Boesch. São Paulo: Casa do Psicólogo.

CRESPO, F. et al. (2007). Desarrollo de la Embriología como ciencia. In. Revista Cuadernos, Vol. 52 No. 1, 2007

CURTIS, H. (1972). Biologia. Barcelona: Omega.

DE LAJONQUIÈRE, L. (1992). De Piaget a Freud: Para repensar as aprendizagens. A (psico)pedagogia entre o conhecimento e o saber. Petrópolis, Rio de Janeiro: Vozes.

DE LA TAILlE, Y. (1994). Prefacio. In: Piaget, J. O Juízo moral na criança. São Paulo: Summus.

(2002a) Cognição, afeto e moralidade. In. Oliveira, M., Rego, T e Souza, D. (orgs.). Psicologia, educação e as temáticas da vida contemporânea. São Paulo: Moderna. (2002b). Vergonha a ferida moral. Petrópolis: Editora Vozes.

DE PINTO, M. (2002). Comment la sexualité vient aux enfants. In: Enfances \& Psy, 1/2002 (no17), p.17-20.

DE SOUZA, M.T.C.C. (2002). As noções de sujeito e objeto na teoria de Jean Piaget. In: Simão, L.M.; De Souza, M.T.C.C. e Coelho, N. Noção de objeto, concepção de sujeito: Freud, Piaget e Boesch. São Paulo: Casa do Psicólogo.

(Org.) (2004a). Os sentidos de construção: o si mesmo e o mundo. São Paulo: Casa do Psicólogo, pp. 37-68.

(2004b). Alteridade e construção do "si mesmo". In: Mitjáns, A.M.; Simão, L.M. (Org.). O Outro no desenvolvimento humano: diálogo para a pesquisa e a prática profissional em Psicologia. São Paulo: Pioneira Thomsom Learning Ltda.

(2006). Relações entre afetividade e inteligência: causalidade ou complementaridade? Considerações a partir da teoria de Jean Piaget. In: De Souza, M.T.C.C.; Bussab, V.S.R. (Org.). Razão e emoção: diálogos em construção. São Paulo: Casa do Psicólogo.

(2011). As relações entre Afetividade e Inteligência no Desenvolvimento Psicológico. In. Psicologia: teoria e pesquisa, Brasília, vol. 27, n. 2, junho 2011

DELAHANTY G. D. e PERRÉS, J. P. (comp.) (1980). Piaget y el psicoanálisis. México: Ed. Universidad Autónoma Metropolitana.

DELVAL, J. (1994). El desarrollo humano. Madrid: Siglo XXI de España. 
(2002). Introdução à Prática do Método Clínico: descobrindo o pensamento das crianças. Porto Alegre: Artmed.

(2007). Aspectos de la construcción del conocimiento sobre la sociedad. In Educar, Curitiba, n. 30, p. 45-64, 2007. Editora UFPR 15

DOLLE, J. M. (1977). De Freud a Piaget. Buenos Aires: Paidós, 1979.

FERREIRA, A. (1993). Minidicionário da língua portuguesa Aurelio. Rio de Janeiro: Nova Fronteira.

FOUCAULT, M. (1988/2010). Historia da sexualidade, tomo 1: A vontade de saber. RJ: Graal.

FREUD, S. (1895/1996). Projeto para uma psicologia cientifica In: Edição Standard Brasileira das Obras Psicológicas Completas de Sigmund Freud. Rio de Janeiro: Imago. (1900/1996). A interpretação dos sonhos. In: Edição Standard Brasileira das Obras Psicológicas Completas de Sigmund Freud. Rio de Janeiro: Imago Editora.

(1905/1996). Três ensaios sobre a sexualidade. In: Edição Standard das obras psicológicas completas de Sigmund Freud. Rio de Janeiro: Imago.

(1907). O esclarecimento sexual das crianças. In: Edição Standard das obras psicológicas completas de Sigmund Freud. Rio de Janeiro: Imago.

(1908/1996). Sobre as teorias sexuais das crianças. In: Edição Standard das obras psicológicas completas de Sigmund Freud, Rio de Janeiro: Imago.

(1910/1996). Uma lembrança de infância de Leonardo Da Vinci. In: Edição Standard das obras psicológicas completas de Sigmund Freud, Rio de Janeiro: Imago.

(1911/1996). Formulações sobre os dois princípios do funcionamento mental. In: Edição Standard das obras psicológicas completas de Sigmund Freud, Rio de Janeiro: Imago. (1913/1989). Totem y tabu. In: Obras completas de Sigmund Freud, Buenos Aires: Amorrortu.

(1914/1996). Introdução ao narcisismo. In: Edição Standard das obras psicológicas completas de Sigmund Freud, Rio de Janeiro: Imago.

(1914/2004). À guisa de Introdução ao narcisismo. In: Obras psicológicas de Sigmund Freud, Escritos sobre a Psicologia do Inconsciente. Rio de Janeiro: Imago.

(1914b/1996). Algumas reflexões sobre a psicologia do escolar. In: Edição Standard das obras psicológicas completas de Sigmund Freud, Rio de Janeiro: Imago.

(1915/1996). O inconsciente. In: Edição Standard Brasileira das Obras Psicológicas Completas de Sigmund Freud. Rio de Janeiro: Imago. 
(1916/1996). Conferências de introdução à psicanálise. In: Edição Standard das obras psicológicas completas de Sigmund Freud, Rio de Janeiro: Imago.

(1923/1996). A organização genital infantil: uma interpolação na teoria da sexualidade. In: Edição Standard das obras psicológicas completas de Sigmund Freud, Rio de Janeiro: Imago.

(1924/1996). A dissolução do complexo de Édipo. In: Edição Standard das obras psicológicas completas de Sigmund Freud, Rio de Janeiro: Imago.

(1925/1996). Algumas conseqüências psíquicas da diferença anatômica entre os sexos. In: Edição Standard das obras psicológicas completas de Sigmund Freud, Rio de Janeiro: Imago.

(1925b/1996). A negativa. In: Edição Standard Brasileira das Obras Psicológicas Completas de Sigmund Freud. Rio de Janeiro: Imago.

(1933/1996). Feminilidade. Conferência XXXIII. In: Edição Standard Brasileira das Obras Psicológicas Completas de Sigmund Freud. Rio de Janeiro: Imago.

(1938/1974). Esboço da psicanálise. In: Os pensadores, vol. XXXIX. São Paulo:

Abril Cultural.

GUIMARÃES, I. (1995). Educação sexual na escola: mito e realidade, Campinas: Ed. Mercado de letras.

IMBASCIATI, A. (1998). Afeto e representação: para uma análise dos processos cognitivos. São Paulo: Ed. 34.

JAGSTAIDT, V. (1987). A sexualidade e a criança. São Paulo: Ed. Manole Ltda.

JERUSAlinsKY, A. (2010). A Psicanálise e Piaget. In: Psicanálise e Desenvolvimento Infantil: um enfoque transdisciplinar. Porto Alegre: Artes e Ofícios, pp. 75-85.

JUNG, C. (1910). Sobre os conflitos da vida infantil. In: $O$ desenvolvimento da personalidade. Petrópolis, RJ: Vozes, 1999.

KESSERLING, T. (2008). Jean Piaget. Caxias do Sul, RS: Educs, pp. 19-47.

KOLHBERG, L. (1966). A cognitive developemental analysis of children's sex role concepts and attitudes. In: Maccoby (org.), The development of sex differences (pp. 82-173). Stanford: Stanford University Press.

KUPFER, M.C. (2003). Afetividade e cognição: uma dicotomia em discussão. In: Arantes, V. (org.) Afetividade na escola: alternativas teóricas e práticas, São Paulo: Summus.

LAPLANCHE, J. e PONTALIS, J.B. (2009). Diccionario de Psicoanálisis. Buenos Aires: Paidós, 1967.

LE MANER, G. (1997). L’identité sexuée. Paris: Dunod. 
LEITE, N. (2007). Teorias sexuais infantis: uma reflexão sobre o corpo-linguagem. In: ETD Educação temática Digital, Campinas, vol. 8.

LEMÈRER, B. (1999). Algumas reflexões a partir do texto de Freud sobre as teorias sexuais infantis. In. Revista Letra Freudiana (“A criança e o saber”). Tradução de Analucia Teixeira Ribeiro pp. 13-19.

MATTHEWS, G. (2001). A filosofia e a criança. São Paulo: Martin Fontes

MENÈS, M. (2002). Une invention pás comme lês autres: les theories sexuelles infantiles. In: La lettre de l'enfance et de l'adolescence, 3/2002(N 49), pp. 29-34.

MIJOLLA-MELLOR, S. (2002). Les mythes magico-sexuels dans l'imaginaire de l'enfant, In: Imaginaire \& Inconscient, 2002/3, N 7, p. 61-70.

(2004). Organes énigmatiques e constructions mythiques, In: Topique, 2004/2, N 87, p. 65-87.

MORENO, M. (1999). Como se ensina a ser menina: o sexismo na escola, São Paulo: Moderna; Campinas: Editora Unicamp.

NASIO, J. D. (2007). Édipo: o complexo do qual nenhuma criança escapa. Rio de Janeiro: Jorge Zahar.

NUNES, C. (1998). O estatuto epistemológico dos discursos contemporâneos sobre sexualidade. Perspectiva, v.16, n. 30, p. 15 - 34, jul./dez.

NUNES, C. e SILVA (2000). A educação sexual da criança. Campinas: Autores Associados. OLIVEIRA, A. (1981). A evolução da medicina: até o inicio do século XX. São Paulo: Pioneira.

PIAGET, J. (1920/1994). A psicanálise e sua relação com a psicologia da criança. In: Delahanty e Perrés (comp.), Piaget y el psicoanálisis. México: Ed. Universidad Autónoma Metropolitana.

(1923a/1994). El pensamiento simbólico y el pensamiento del niño. In: Delahanty

e Perrés (comp.), Piaget y el psicoanálisis. México: Ed. Universidad Autónoma Metropolitana,.

(1923b/1999) A linguagem e o pensamento da criança. SP Martin fontes. (1924/1947). O raciocínio na criança. Rio de Janeiro: Record. (1926/ 2005). A representação do mundo na criança. São Paulo: Idéias\&Letras. (1933/ 1994). El psicoanálisis y el desarrollo intelectual. In: Delahanty e Perrés (comp.), Piaget y el psicoanálisis. México: Ed. Universidad Autónoma Metropolitana. (1932/1994). O Juizo moral na criança. São Paulo: Ed. Summus. (1937/1975). A construção do real na criança. Rio de Janeiro: Zahar. 
(1945/1975). A formação do símbolo na criança. Rio de Janeiro: Zahar.

(1953-54/1994). Las relaciones entre la inteligencia y la afectividad en el desarrollo del niño, In: Delahanty e Perrés, Piaget y el psicoanálisis. México: Ed. Universidad Autónoma Metropolitana.

(1953-54/2005). Inteligencia y afectividad. Prólogo de Mario Carretero. Buenos Aires: Aique

(1964/1975). Seis estudios de psicología. Barcelona: Editora Seix Barral. (1967/1980). O método psicogenético e a epistemologia genética. In: Lógica e conhecimento científico. Porto: Civilização.

(1969/1975). Psicologia e Pedagogia. Rio de Janeiro: Forense Universitária.

(1970a/1983). A Epistemologia genética, In: Piaget, São Paulo: Victor Civita,. (1970b/1983). Inconsciente cognitivo e afetivo. In: Piaget. São Paulo: Victor Civita.

(1971/1973). Las explicaciones causales. Primera parte. Barcelona: Barral.

(1972/1983). Problemas de Psicología Genética, In: Piaget, São Paulo: Victor Civita.

(1972/1988). Oú va l'éducation. Paris:Ed. Gallimard, Collection Folio/essais.

PIAGET, J. e INHELDER B. (1955/1976). Da lógica da criança à lógica do adolescente. Sao Paulo: Ed. Pionera. (1966/1972). La Psicología del Niño. Madrid: Ed. Morata.

SCHLEMENSON, S. (2008). Niños que no aprenden. Buenos Aires: Paidós Educador.

SHEJTMAN, F. (2007). La liquidación de las perversiones. In: ANCLA, Gênero o Sexuación? Revista de la cátedra II de Psicopatologia de la Universidad de Buenos Aires.

SOLER, C. (2002). A hipótese lacaniana. In: Revista Percurso n ${ }^{\circ} 29,2 / 2002$. (2007). Qué se espera del psicoanálisis y del psicoanalista? Buenos Aires: Letra Viva.

TELLES, V. (1997). A leitura cognitiva da psicanálise: problemas e transformações de conceitos. In: Psicologia USP vol. 8 n. 1 São Paulo.

VANIER, A. (1996). Élements d'introduction à la psychanalyse. Paris: Ed. Nathan Université.

WINNICOTT, D. (1982). A criança e o seu mundo. Rio de Janeiro: LTC.

ZORNIG, S. (2008). As teorias sexuais infantis na atualidade: algumas reflexões. In: Psicologia em estudo, v.13 n.1 Maringá. 


\section{ANEXOS}

\section{I) Roteiro da entrevista}

Apresentação da dinâmica: "Vou te mostrar uns desenhos e gostaria que você me respondesse algumas perguntas"

\section{Prancha 0- (Cinderela limpando - instruções da dinâmica)}

- O que você está vendo?

- Você acha que é possível que os animais limpem a casa? Por quê?

(Estas serão as questões iniciais adaptadas aos desenhos das pranchas 1, 2, e 4)

\section{Prancha 1- (O ovo- Nascimento e origem do bebê)}

- E de verdade, um bebê pode sair de um ovo?

1. De onde você acha que vem um bebê?

2. Como é que você sabe?

3. (caso responda que sai da barriga) Como faz o bebê para sair da barriga?

\section{Prancha 2- (A cegonha - Nascimento e origem do bebê)}

4. Sabia que quando mostro esse desenho às crianças menores elas às vezes me dizem que são os pais que queriam um bebê e é o pássaro que o está trazendo. Se a gente precisasse contar às crianças menores o que é preciso fazer para ter um bebê, o que é que a gente tem que dizer para eles?

\section{Prancha 3 - (Os Dálmatas - Nascimento e fecundação nos animais)}

5. Como nascem os cachorrinhos?

6. Como chegam à barriga da cachorra? (Caso tenha falado sobre a barriga)

\section{Prancha 4 - (O Repolho - Vida intrauterina)}

8. (caso responda que o bebê sai da barriga) Quanto tempo o bebê fica na barriga da mãe?

9. Como faz para crescer? Como come?

10. Onde ele estava antes de estar na barriga da mamãe?

\section{Prancha 5 - (O Casamento - Representação do casamento)}

12. O que é o casamento? Por que as pessoas se casam?

13. O que eles (mostrando os personagens) têm que fazer se querem ter um bebê?

14. a) Você acha que uma mulher poder ter um bebê sozinha, sem um homem? b) E um homem sozinho, sem uma mulher?

\section{Prancha 6 - (Bebês - Diferença entre meninos e meninas)}

15. Como se sabe se os bebês são meninos ou meninas dentro da barriga?

16. Se uma menino quer virar menina pode? (caso responda não) E se brinca de bonecas, deixa o cabelo longo e usa vestido?

17. Se uma menina quer virar menino pode? (caso responda não) E se brinca de carrinhos, curta o cabelo e usa sempre calça?

Fechamento do encontro: Agora, se você quiser, pode fazer um desenho nesta folha usando as cores que você prefira. 
II) Pranchas ilustradas

Prancha 0

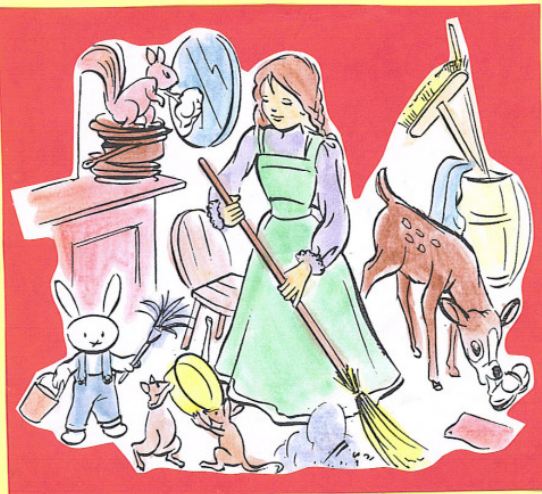

Prancha 1

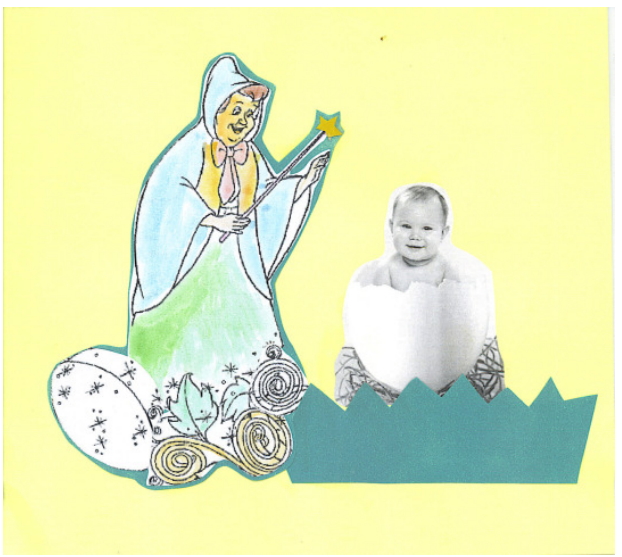

Prancha 2

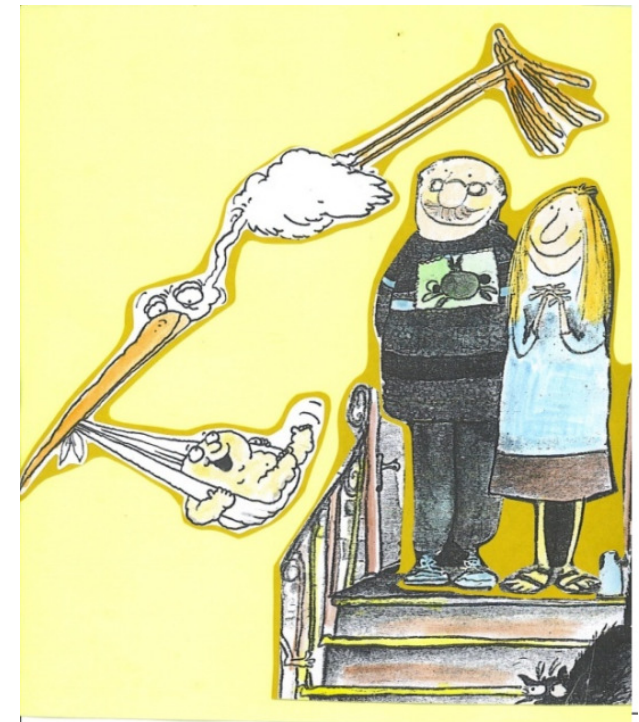


Prancha 3

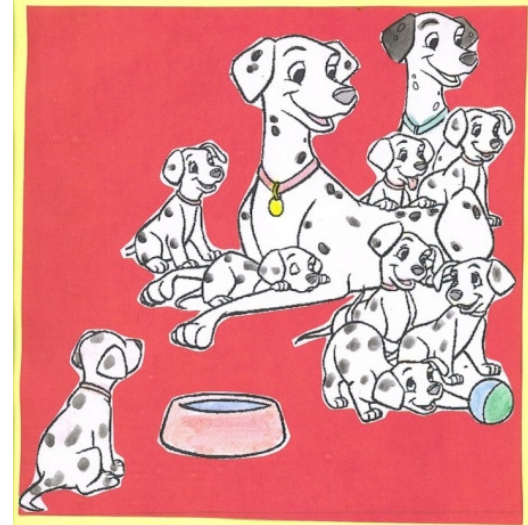

Prancha 4

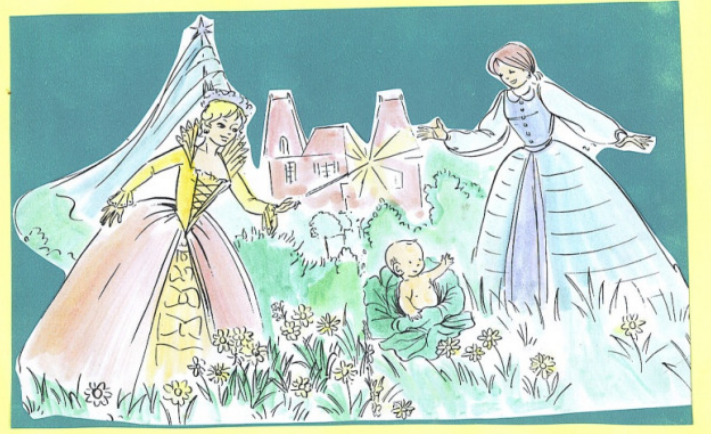

Prancha 5

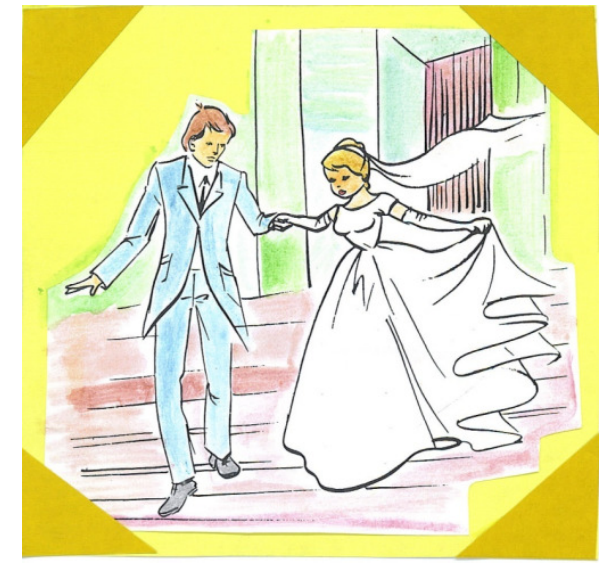

Prancha 6

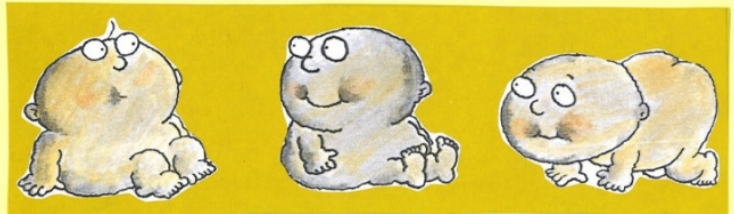




\section{III) Autorização assinada pelos pais}

Prezada família:

Meu nome é Mariana Garbarino e sou estudante de Pós-Graduação do Instituto de Psicologia da Universidade de São Paulo. Estou realizando uma pesquisa sobre os conhecimentos espontâneos das crianças acerca da origem e nascimento dos bebês. Envio embaixo detalhes sobre o meu trabalho e a autorização para que, caso vocês o permitam, possa entrevistar seus filhos.

Muito obrigada.

Cordialmente,

Mariana

خిs

INSTITUTO DE PSICOLOGIA

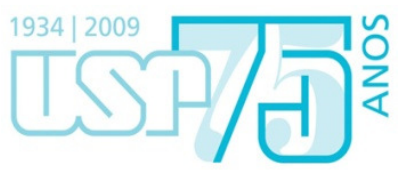

\section{TERMO DE CONSENTIMENTO LIVRE E ESCLARECIDO}

(autorização para participar na atividade de pesquisa)

Título da Pesquisa: Crenças sobre a origem dos bebês em crianças de 4 a 8 anos: considerações a partir da psicogênese piagetiana e da psicanálise.

Natureza da pesquisa: A pesquisa tem como objetivo geral investigar os elementos e temas comuns das crenças sobre a origem dos bebês em crianças de 4 a 8 anos.

Participantes da pesquisa: Participarão da pesquisa 60 crianças com idades entre 04 a 08 anos de diferentes escolas públicas e privadas de Campinas.

Envolvimento na pesquisa: Ao participar deste estudo, você permitirá que seu filho(a) seja entrevistado pela pesquisadora. Todas as entrevistas serão realizadas na própria escola. A entrevista, que será individual, tem como objetivo registrar os conhecimentos espontâneos das crianças sobre a origem dos bebês, o que é que eles pensam ao respeito e como é que, sozinhos, conseguem explicar o nascimento humano. O encontro terá uma duração de entre 10 a 15 minutos, levando em consideração que a sua realização não afete nenhum momento significativo das atividades escolares. A dinâmica da entrevista será apresentada como um jogo que consiste na observação de 6 pranchas com ilustrações de contos de fada e personagens infantis. As crianças responderão perguntas sobre os desenhos, para que justifiquem se seria possível que o observado aconteça na vida real e por que (por exemplo, uma cegonha que carrega um bebê). Ao terminar a entrevista a criança será convidada para fazer, se quiser, 
um desenho livre (poderão desenhar o que tenham vontade), antes do retorno à sala de aula. Vale ressaltar que não se realizará nenhum tipo de explicação, correcão, sugestão ou intervencão educativa por parte da pesquisadora em nenhum momento, pois o objetivo é conhecer os conhecimentos espontâneos das crianças sobre a origem dos bebês. O áudio das entrevistas será registrado mediante um gravador e a transcrição das respostas será feita de maneira anônima.

Riscos e Confidencialidade: De acordo com a Resolução No 196/96 de 10 de outubro do Conselho Nacional de Saúde e a Resolução No 016/2000 de 20 de dezembro de 2002 do Conselho Federal de Psicologia assegura-se que a presente pesquisa não traz complicações ou riscos de qualquer espécie, já que os procedimentos não contêm nenhuma pergunta de foro íntimo que possa expor o participante à situação desconfortável. Estes, por sua vez, serão esclarecidos sobre todos os procedimentos a serem adotados e colaborarão voluntariamente. Sendo assim, todos os participantes têm a liberdade de não querer participar desta pesquisa, assim como de pedir esclarecimentos que considerem necessários. Importante ressaltar que o presente projeto de pesquisa passou por avaliação do Comitê de Ética em Pesquisa com Seres Humanos do Instituto de Psicologia da Universidade de São Paulo (Av. Prof. Mello de Moraes, 1721 - Bloco G / sala 22 - Cidade Universitária. Fone: 30970529).

Pagamento: Não haverá nenhum tipo de despesa com a participação nem qualquer tipo de pagamento.

Em caso de eventuais dúvidas, você terá acesso à profissional responsável pela pesquisa para seu esclarecimento.

Tendo em vista os itens acima apresentados, eu, de forma livre e esclarecida, manifesto interesse em que meu (minha) filho (a) participe da pesquisa, se assim o desejar.

Nome do participante (criança)

Nome do responsável:

Assinatura

Local e data

Mariana Inés Garbarino

Pesquisadora
Maria Thereza C. Coelho de Souza

Orientadora

Contato: Av. Prof. Mello de Moraes, 1721 - Bloco F / sala 154 - Cidade Universitária, São Paulo. tel- (11) 3091-4355. E-mail: marianagarbarino@usp.br 


\section{IV) Aprovação do Comitê de Ética}
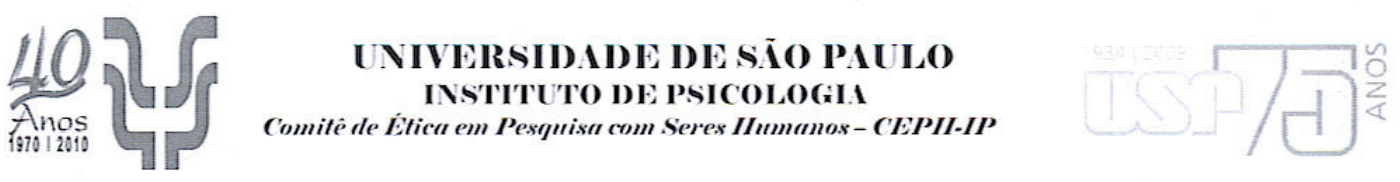

Of.123/2010-CEPH-IP - 14/12/2010

GAC

Senhora Professora,

O Comitê de Ética em Pesquisa com Seres Humanos do IPUSP (CEPHIP) aprovou, conforme parecer anexo, o Projeto de Pesquisa $n^{\circ} 2010.030$, intitulado "Crenças sobre a origem dos bebês em crianças de 4 a 8 anos: uma abordagem a partir da psicogênese piagetiana e da psicanálise" a ser desenvolvida pela Pesquisadora Mariana Inés Garbarino, nivel Mestrado, a ser orientada pelo Profa. Dra. Maria Thereza Costa Coelho de Souza, junto ao Programa de Psicologia Escolar e do Desenvolvimento Humano do IPUSP.

Atenciosamente,

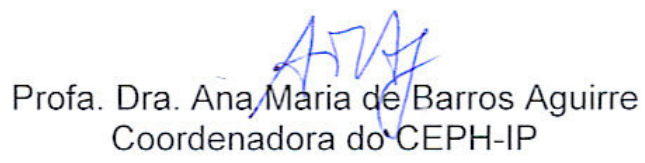

IIma. Sra.

Profa. Dra. Maria Thereza Costa Coelho de Souza

Departamento Psicologia da Aprendizagem do Desenvolvimento e da Personalidade IPUSP 